\title{
IntechOpen
}

\section{Genetic Transformation in Crops}

Edited by Kin-Ying To 



\section{Genetic Transformation in Crops}

Edited by Kin-Ying To 

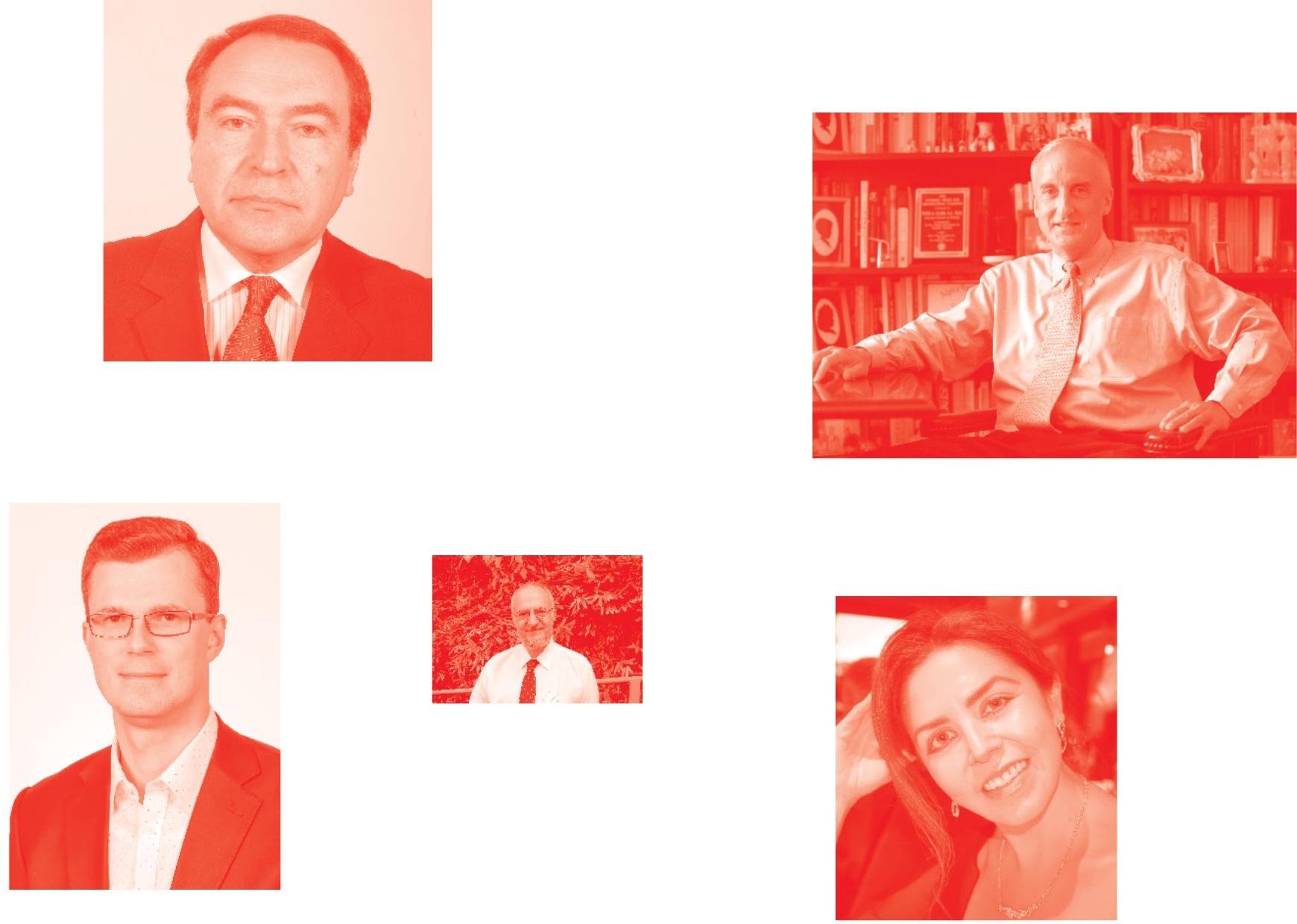

Supporting open minds since 2005
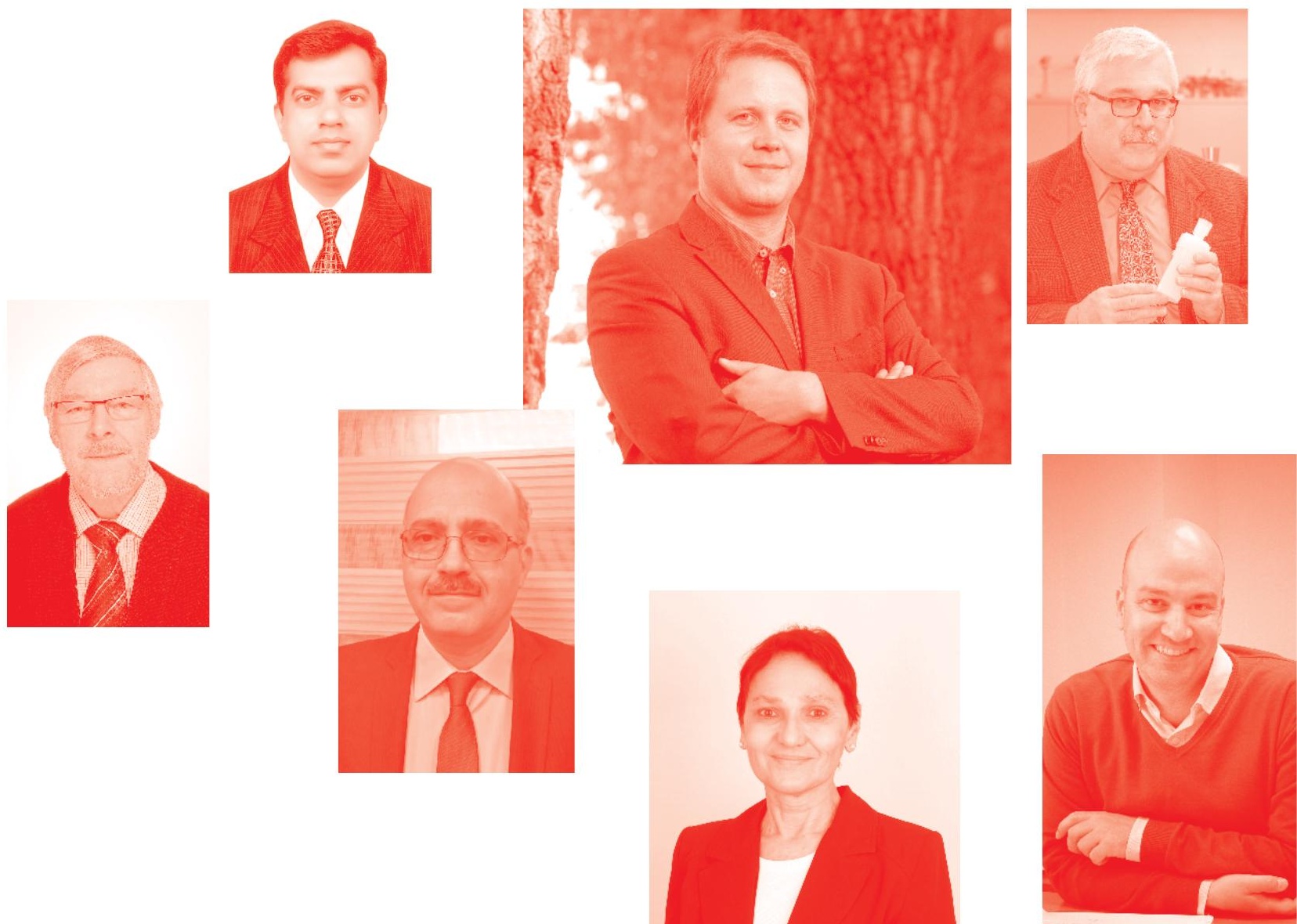
Genetic Transformation in Crops

http : //dx . doi . org/10.5772/intechopen . 87516

Edited by Kin-Ying To

\section{Contributors}

Risha Amilia Pratiwi, Muhammad Imam Surya, Kin-Ying To, Po-Yen Chen, Yung-Ting Tsai, Devaiah Kambiranda, James Obuya, Janana Snowden, Penny Hundleby, Monika Chhetry, Tushar Ranjan, Ravi Kumar, Kumari Rajani, Auroshikha Mohanty, Priyanka Kumari, Khushbu Jain, Jitesh Kumar, Pritam Jadhav, Getachew Alamnie, Ekatpure Sachin Chandrakant, Wagh Yogesh Sahebrao, Berhanu Andualem

๑) The Editor(s) and the Author(s) 2020

The rights of the editor(s) and the author(s) have been asserted in accordance with the Copyright, Designs and Patents Act 1988. All rights to the book as a whole are reserved by INTECHOPEN LIMITED. The book as a whole (compilation) cannot be reproduced, distributed or used for commercial or non-commercial purposes without INTECHOPEN LIMITED's written permission. Enquiries concerning the use of the book should be directed to INTECHOPEN LIMITED rights and permissions department (permissions@intechopen.com).

Violations are liable to prosecution under the governing Copyright Law .

\section{(c) BY}

Individual chapters of this publication are distributed under the terms of the Creative Commons Attribution 3.0 Unported License which permits commercial use, distribution and reproduction of the individual chapters, provided the original author(s) and source publication are appropriately acknowledged. If so indicated, certain images may not be included under the Creative Commons license. In such cases users will need to obtain permission from the license holder to reproduce the material. More details and guidelines concerning content reuse and adaptation can be found at http : //www . intechopen . com/copyright-policy . html.

Notice

Statements and opinions expressed in the chapters are these of the individual contributors and not necessarily those of the editors or publisher. No responsibility is accepted for the accuracy of information contained in the published chapters. The publisher assumes no responsibility for any damage or injury to persons or property arising out of the use of any materials, instructions, methods or ideas contained in the book.

First published in London, United Kingdom, 2020 by IntechOpen

IntechOpen is the global imprint of INTECHOPEN LIMITED, registered in England and Wales, registration number: 11086078 , 5 Princes Gate Court, London, SW7 2QJ, United Kingdom Printed in Croatia

British Library Cataloguing-in-Publication Data

A catalogue record for this book is available from the British Library

Additional hard and PDF copies can be obtained from orders@intechopen .com

Genetic Transformation in Crops

Edited by Kin-Ying To

p. cm.

Print ISBN 978-1-83962-450-6

Online ISBN 978-1-83962-451-3

eBook (PDF) ISBN 978-1-83962-452-@ 


\section{We are IntechOpen, \\ the world's leading publisher of Open Access books}

Built by scientists, for scientists

\section{$5,000+$ \\ $125,000+$ \\ International authors and editors \\ $140 \mathrm{M}+$ \\ Downloads}

Our authors are among the

151

Countries delivered to

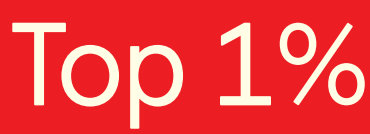

most cited scientists

Contributors from top 500 universities

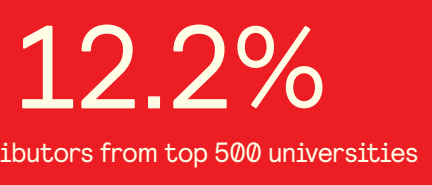

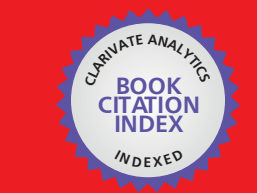

WEB OF SCIENCE ${ }^{\text {M }}$

Selection of our books indexed in the Book Citation Index

in Web of Science ${ }^{\mathrm{TM}}$ Core Collection (BKCI)

\section{Interested in publishing with us? \\ Contact book.department@intechopen.com}

Numbers displayed above are based on latest data collected.

For more information visit www.intechopen.com 



\section{Meet the editor}

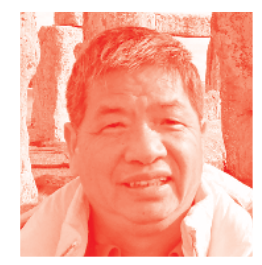

Dr. Kin-Ying To received a Ph.D. degree at the Institute of Botany, National Taiwan University, Taiwan. After postdoctoral training at Chang-Gung University (Taoyuan, Taiwan), Harvard University (Boston, USA), and Academia Sinica (Taipei, Taiwan), Dr. To joined the Agricultural Biotechnology Research Center, Academia Sinica, Taiwan, in 1999. Currently, Dr. To is working as an Associate Research Specialist. Dr. To has published over 30 research articles and reviews, 3 book chapters, and also received 2 patents and several research grants. In addition, Dr. To has been serving as a reviewer for a range of journals and a lecturer in some courses. Research interests in Dr. To's laboratory include plant tissue culture and genetic engineering in valuable medicinal and crop plants, Agrobacterium-mediated transformation, molecular breeding and plant biotechnology. 



\section{Contents}

Preface

Chapter 1

Agrobacterium-Mediated Transformation

by Risha Amilia Pratiwi and Muhammad Imam Surya

Chapter 2

Grapevine Improvement through Biotechnology

by Devaiah Kambiranda, James Obuya and Janana Snowden

Chapter 3

Brassica oleracea Transformation

by Penny Hundleby and Monika Chhetry

Chapter 4

Construction and Evaluation of Chloroplast Expression Vectors

in Higher Plants

by Po-Yen Chen, Yung-Ting Tsai and Kin-Ying To

Chapter 5

RNA Interference: An Overview

by Jitesh Kumar, Khushbu Jain, Priyanka Kumari, Auroshikha Mohanty,

Kumari Rajani, Ravi Ranjan Kumar and Tushar Ranjan

Chapter 6

RNAi Induced Gene Silencing Journey from Simple dsRNA

to High-Throughput Intron Hairpin RNA Construct in Crop

Improvement

by Jadhav Pritam Ramesh, Ekatpure Sachin Chandrakant

and Wagh Yogesh Sahebrao

Chapter 7

Biosafety Issues of Unintended Horizontal Transfer of Recombinant DNA

by Getachew Alamnie and Berhanu Andualem 



\section{Preface}

It is estimated that a $70-100 \%$ increase in cereal food supply is required to feed the predicted world population of 9.8 billion people by 2050. Unfortunately, climate change, decreasing environmental resources, and increasing human population are major factors limiting agricultural production worldwide. Climate change will aggravate the effects on crops of various stresses such as pathogen attack, extreme temperatures, drought, salinity and submergence with water, and is set to have a profound impact on food production. To breed crops with increased yield and resistance to biotic/abiotic stresses, it is necessary to effectively utilize the current methodologies and further develop new breeding technologies as soon as possible.

Genetic crossing, selection of natural or artificial mutations, and transgenics, are the major techniques for plant breeding. Among them, plant transformation has been widely adopted as the most effective method in understanding how the plant works, improving crop characteristics, and producing value compounds. Back to 1974, Marc Van Montagu and Jeff Schell at Ghent University (Belgium) were credited with discovering that the soil bacterium Agrobacterium uses a plasmid, now known as the Ti plasmid, to transfer its genetic material to a plant cell. Since then, Agrobacterium-mediated transformation has been rapidly developed and recognized as the most powerful method for genetic engineering and creation of transgenic plants. In 1987, the first field trial of a genetically modified (GM) potato was reported in the United Kingdom, and the transgenic potatoes had the GUS reporter gene. In 1994, Flavr Savr tomatoes (Calgene company) went on sale in the USA. The polygalacturonase gene which degrades pectin in cell walls and results in the softening of fruit, was knocked out in the transgenic tomato, so that the GM fruits remain firm for a longer time, and allowed them to develop a better flavor. This GM tomato was the first commercially available GM food. However, controversial debates regarding public concerns, risks, and biosafety issues have arisen since the first GM food became available on the market, and these controversies seem to continue. Nowadays, only a few important crops such as soybean, corn, canola, cotton, etc., have been successfully engineered for specific characteristics, and are available on the market.

The first chapter of this book is an overview of Agrobacterium-mediated transformation. This chapter extensively describes updated information related to Agrobacterium-mediated transformation, including the history of Agrobacterium, the natural process of Agrobacterium, comprehensive mechanism of gene transfer from Agrobacterium to host plant, and the general protocol of Agrobacteriummediated transformation in higher plants. In brief, this chapter provides fruitful information regarding Agrobacterium-mediated transformation, and will definitely be useful in the field of transformation. The second chapter extensively describes grapevine improvement through biotechnology. Grapes are one of the most widely cultivated fruit crops worldwide. Authors in this chapter mention the achievement of the sequencing of the multiple grape genomes and its applications to grape improvement. For grapevine breeding, several techniques including marker-assisted selection, RAPD markers, microsatellites, single-nucleotide polymorphism (SNP), genetic transformation, etc., have been clearly described. This information should 
be very useful to grapevine breeders. The third chapter describes a simple and step-by-step Agrobacterium tumefaciens-mediated transformation method for the diploid brassica species Brassica oleracea, an important crop worldwide. The transformation efficiency is estimated as $25 \%$. It should help for establishment of transformation in Brassica olevacea. Chapter 4 describes chloroplast transformation in higher plants. Chloroplast transformation, as compared with nuclear transformation, offers several important features, including (1) high-level expression of the transgenes; (2) preventing pollen transmission of transgene due to the maternal inheritance of the plastid genome in most plants; and (3) precise integration into plastid genome of the host plant via a homologous recombination process. In this chapter, step-by-step cloning protocols of chloroplast expression vectors specific for spinach, tomato and Nicotiana benthamiana are described. Moreover, PCR analysis confirms integration of transgenic expression cassette into the chloroplast genome of $N$. benthamiana, and transgenic genes can be transmitted into progenies. This chapter provides experimental-based data, and these vectors will be useful for chloroplast transformation. There are two chapters related to virus-induced gene silencing (VIGS). Chapter 5 describes the molecular mechanism as well as application of RNA interference (RNAi) and VIGS in plants, and provides mass information in the field of plant molecular biology. This information should be useful for plant pathologists and plant biologists. Chapter 6 describes the basic mechanisms and applications of RNAi in gene silencing area. Back to several decades, the RNAi pathway was first observed in nematodes in response to double-stranded RNA (dsRNA) which resulted in sequence-specific gene silencing. Now, this phenomenon of RNAi induced gene silencing has been reported in almost all species. Thus, understanding the role of short interfering RNA (siRNA) and machinery involved in the RNAi pathway will lead to application of this pathway as a technique in therapeutic applications and crop improvement. Furthermore, detail considerations regarding vector construction for RNAi experiments are provided. This information is very useful for all readers. Chapter 7 describes the biosafety issues which mainly come from genetically modified organisms (GMOs). Horizontal gene transfer (HGF) is defined as the transfer of genetic material from one organism to another independent organism. By using molecular breeding techniques, foreign expression cassette carrying antibiotic or herbicide selection marker and transgene with valuable trait can be integrated into the chromosome of host cell. Transgenes in these GMOs may arise a potential question: transgenes may transfer into the environment or human by HGT. In this chapter, the authors extensively explain the mechanisms and detections of HGT, and conclude that HGT from GMOs can be negligible to humans or to the environment. Information provided here is valuable to this field.

Finally, I would like to thank each author who has contributed a chapter to make this book possible. 


\title{
Agrobacterium-Mediated Transformation
}

\author{
Risha Amilia Pratiwi and Muhammad Imam Surya
}

\begin{abstract}
Agrobacterium-mediated transformation (AMT) heavily relies on the capability of bacterial pathogen Agrobacterium tumefaciens in transferring foreign genes into a wide variety of host plants. Currently, AMT is the most commonly used method for generating transgenic plants. On the other hand, A. tumefaciens was very useful for plant breeding. It also accelerated the technology of plant breeding to obtain specific characters. Gene transfer from bacteria to plants is a complex mechanism that involves several functional steps. This chapter will give brief information related to AMT mechanism, including the history of crown gall disease, the natural pathogenesis of A. tumefaciens, and the general protocol of AMT.
\end{abstract}

Keywords: Agrobacterium tumefaciens, crown gall disease, natural pathogenesis, plant transformation, plant breeding technology

\section{Introduction}

Plants are essential natural resource for the survival and welfare of human being. The many uses of plants can be summarized in "TREES" word, an abbreviation for timber, restoration, ecological, educational and recreation, and source of sustenance [1]. Given the importance of plants, people have been upgrading both productivity and quality of cultivated plants. Plant breeding technique comes as an art, science, and business of manipulating the genetic pattern of plants by humans to develop superior cultivars, related to improving humankind, ranging from unintentional changes that are resulted by conventional selection to precision breeding by molecular tools $[2,3]$.

Plant breeding activities are considered to have been going on for at least 10,000 years, as long as the age of human civilization from nomadic hunter-gatherer to sedentary lifestyle [2]. The earlier farmers collected their best seeds to be replanted. This conscious human selection activity to get the best performing plant, although relatively simple, is the fundamental principle of phenotype-selection based. Later people incorporated some superior properties of different closely related parents through artificial mating or sexual hybridization, generating new genetic recombination which dramatically led to increased crop yields, easy cultivation, tolerant to environmental stresses, and resistant against pest [2-4].

The advance of molecular biology and genetic engineering provides new opportunities in plant breeding technology. Moreover, the application of molecular markers developed from QTL analysis enhances breeding efficiency by enabling marker-assisted selection for particular agronomic traits [5]. On the other hand, next generation sequencing (NGS) has revolutionized genomic and transcriptomic 
approaches to biology. These new sequencing tools are also valuable for discovery, validation, and assessment of genetic marker in populations. NGS technologies have conferred new opportunities for high-throughput genotyping in various plant species. Recent improvements in high-throughput sequencing have enable sequences to be used to detect and score single nucleotide polymorphisms (SNPs) by bypassing time-consuming process of marker development. However, genotypeby-sequencing (GBS), a series of genetic analyses that includes molecular marker discovery and genotyping using NGS technologies, has opened new possibilities in plant breeding and plant genetics studies, including linkage maps, genomewide association studies, genomic selection, and genomic diversity studies [6]. Furthermore, horizontal gene transfer (HGT), also known as lateral gene transfer, refers to the movement of genetic information across normal mating barriers, between more or less distantly related organisms, and thus stands in distinction to the standard vertical transmission of genes from parent to offspring [7]. HGT from bacteria to plants has been restricted to Agrobacterium rhizogenes, and the related bacterium $A$. tumefaciens transforms a wide variety of host plants by transferring a segment of the large tumor-inducing plasmid, called T-DNA into host cells [8]. Most genetic engineering of plants uses AMT to introduce novel gene content.

The development of AMT technology is supported by research on RNA interference technology for functional analyses of genes involved in transformation mechanism or gene(s) of interest and gene editing technology that allows precise manipulation of targeted genome sequences [9]. Although there are several species of Agrobacterium that have the capability to cause tumors-such as A. rhizogenes that cause hairy roots disease, the discussion of Agrobacterium-mediated transformation in this chapter specifically refers to A. tumefaciens. The Agrobacterium-plant interaction is a complex process that its effectiveness and efficiency are affected by many factors. This review focuses on the mechanism of AMT and updates technology to increase the successfulness of plant-gene transformation mediated by A.tumefaciens.

\section{Agrobacterium-mediated transformation mechanism}

\subsection{History of crown gall disease}

The generation of transgenic plant mediated by A. tumefaciens basically mimics the event of naturally plant transformation. The dawn of natural plant transformation study began when fleshy rough roundish surface morphology on the roots' crown (region joining root and shoot) of over 20 different fruit trees was observed [10]. To investigate the causative agent of these tumor-like outgrowths later named "crown gall disease," infected root crown tissues were isolated. The bacteria described as Agrobacterium tumefaciens then were presented [11]. While these Gram-negative soil bacteria were inoculated to wounded young tissues of healthy plants, secondary tumors that cannot be distinguished from the crown gall were produced. On the other hand, the old tissues were not very susceptible [10].

The development of in vitro cultivation technique supports the study of secondary tumor. Explant derived from the interior of secondary tumor continued to unlimited proliferation in auxin in auxin and cytokinin lacking medium and synthesized unusual amino acid derivative; guanido amino acids octopine N2-(D-1carboxyethyl)-L-arginine and nopaline N2-(1,3-dicarboxypropyl)-L-arginine $[9,12]$. Both properties distinguished tumor cells than normal cells.

Bacterial isolation from secondary tumor cultures revealed that no one of these cultures has yielded any growth of $A$. tumefaciens. Injection of paste from these 
bacteria-free cultures to healthy plants exhibited no evidence of tumor initiation as it is observed due to paste injection from young primary tumors. The fact that volume of secondary tumor still increased-although bacteria were absent, indicated that bacteria only trigger tumorigenesis, not involved in the whole process. Somehow, the host cells were permanently transformed so that they were able to convert normal cells into neoplastic cells [13].

Further investigation to confirm the involvement of $A$. tumefaciens in early step of tumorigenesis was conducted through temperature challenge. Bacterial inoculation on periwinkle plant (Vinca rosea L.) at temperature of $32^{\circ} \mathrm{C}$ did not inducted swelling growth, even bacterial and plant cells grew well at that temperature. The bacterial inability to forming tumorous property was not influenced by host plant physiological disturbances as a whole but was solely dependent upon environmental change of bacterial inoculation site, in this case an elevated temperature.

Plants inoculated with bacteria at a temperature of $26^{\circ} \mathrm{C}$ for 5 days, before being held at $32^{\circ} \mathrm{C}$, retained tumorigenic state. These periods provided sufficient opportunity for bacteria to interact with host plants, and then they drove the cellular alteration of the plants. Once the cellular alteration was fully complete, temperature at $32^{\circ} \mathrm{C}$ would not matter; plants were entirely independent in converting normal cells into neoplastic cell. The nature of plant oncogenic transformation as bacterial influence was known as "tumor-inducing principle" [13,14].

The development of molecular technique made a breakthrough in the investigation of the origin of tumor-inducing principle. On the examination of the pathogenic strains of $A$. tumefaciens, one or several homolog large ( $\pm 140-235 \mathrm{kbp}$ in size) supercoiled circular plasmids were isolated [15]. None of the avirulent Agrobacterium strains tested belonged to such a plasmid. Based on its association in inducing tumors, the plasmid was called "tumor-inducing(Ti)-plasmid" [15, 16].

Ti-plasmid borne harbored by four apparently distinct genetic loci (Figure 1). Three loci that consist of genes regulating auxin, cytokinin, and opine synthase are located on T-DNA, a highly conserved DNA fragment defined by $25 \mathrm{bp}$ repeat sequence borders on each end. The genes regulating auxin and cytokinin accumulation determine the oncogenicity of the plasmid. The gene regulating opine synthesis is necessary for expression in host plants as exclusive nutrition for A. tumefaciens [17]. The fourth locus, apart from T-DNA, controls the catabolism of opine compound $[9,20]$. All genes carry the signal necessary for the expression in host plant cell. During bacterial infection to host cell, only T-DNA was cleaved out of the Ti-plasmid borne, transferred, and ultimately incorporated to DNA nuclear of host plant cells $[18,19]$. Therefore, the complete Ti-plasmid was not found in tumor cells, given their relatively large size could not infiltrate host nuclear ore complex passively [15]. Genes regulating auxin and cytokinin synthesis modifying the phytohormone ratio in the host cell resulting uncontrolled cell proliferation that leading to tumor growth.

\subsection{The natural pathogenesis of $A$. tumefaciens}

AMT is a complicated mechanism, which includes (1) signal recognition from plant host to A. tumefaciens, (2) T-DNA processing, (3) T-DNA traveling in plant host cell, (4) T-DNA integrating to plant host genome, and (5) expression of T-DNA in the plant host cell. The mechanism of T-DNA transfer is facilitated by a set of virulent genes located on Ti-plasmid borne [approximately 35 virulent genes grouped in at least 8 operons, $\operatorname{vir} \mathrm{A}$, vir $\mathrm{B}, \operatorname{vir} \mathrm{C}, \operatorname{vir} \mathrm{D}, \operatorname{vir} \mathrm{E}, \operatorname{vir} \mathrm{F}, \operatorname{vir} \mathrm{G}$, and $\operatorname{vir} \mathrm{H}$, encoding VirA, VirB, VirC, VirD, VirE, VirF, VirG, and VirH protein, respectively (Figure 1)], apart from T-DNA, whereas others are on chromosome (chromosomal virulent genes—chv) [22, 23]. 


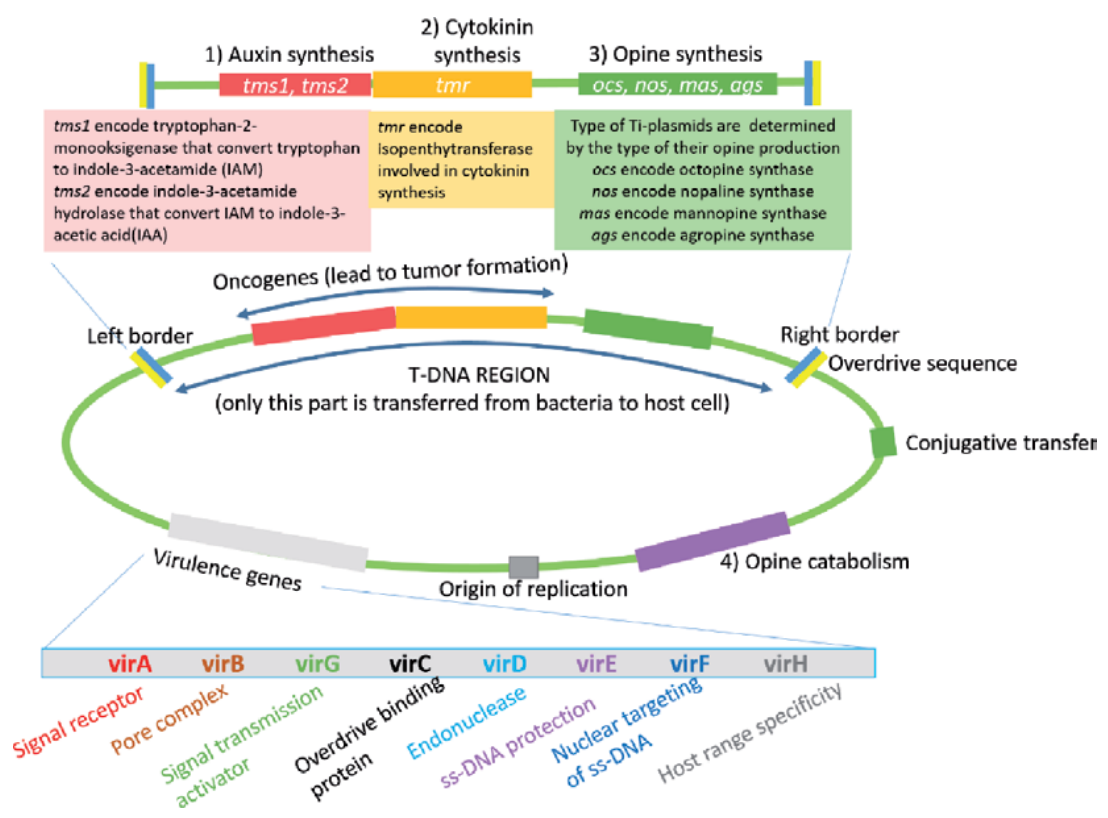

Figure 1.

Schematic representation of a Ti-plasmid borne (not to scale, modified from [20, 21]).

\subsubsection{Signal recognition}

Agrobacterium-plant interaction occurs when a large plant-derived chemicals, which include organic acid compounds ( $\mathrm{pH}$ 5.0-5.8) as routine secreted chemical and phenolic compounds as the wound-releasing chemical, are exposed to the bacteria. Signal recognition of $A$. tumefaciens to plant cell involves three systems (Figure 2) [24]. First, bacterial chemotaxis attracted by phenolic compounds that are exuded from fresh wound site of plants, such as acetosyringone and $\alpha$-hydroxy acetosyringone [25]. Initially, bacteria engage with plant cell surface reversibly, stimulating adhesion production that causes adhesion through unipolar polysaccharide (UPP)-dependent polar attachment and UPP-nondependent attachment. This irreversible surface attachment establishes a site for multicellular biofilms formation, matrix elaboration, cell division, biofilm maturation, and "buddy daughter" cell dispersal [26]. Secondly, host signal compounds are also recognized by transmembrane protein receptors (VirA) on periplasmic space of bacterial cell that trigger phosphorylation of positive regulatory protein VirG [25-27]. Thirdly, protein ChvG/ChvI encoded by chromosomal virulent genes perceive acidity from sugar that activate basal expression of $\operatorname{vir} \mathrm{G}$ too [22]. The phosphorylated VirG leads to the activation of another virulence gene [25]. Monosaccharides enhance signaling process by binding with ChvE then synergize with VirA [28].

\subsubsection{T-DNA processing}

The process of excising T-DNA from Ti-plasmids depends on VirD1 and VirD2 as endonucleases. The $25 \mathrm{bp}$ border sequences on the bottom strand of T-DNA act as nicking site for VirD1 and VirD2. VirD1, a site-specific helicase, unwinds double-stranded T-DNA. A nuclease, VirD2, cuts the bottom strand of T-DNA from the right and left border, becoming single-stranded linear DNA termed T-strand $[21,29]$. VirD2 then covalently caps the $5^{\prime}$ end of T-strand at the right border, forming the VirD2/T-strand complex [28]. The $3^{\prime}$ end of the nicked right border acts as a priming site for the bottom strand of T-DNA regeneration [29]. VirC1 binding 


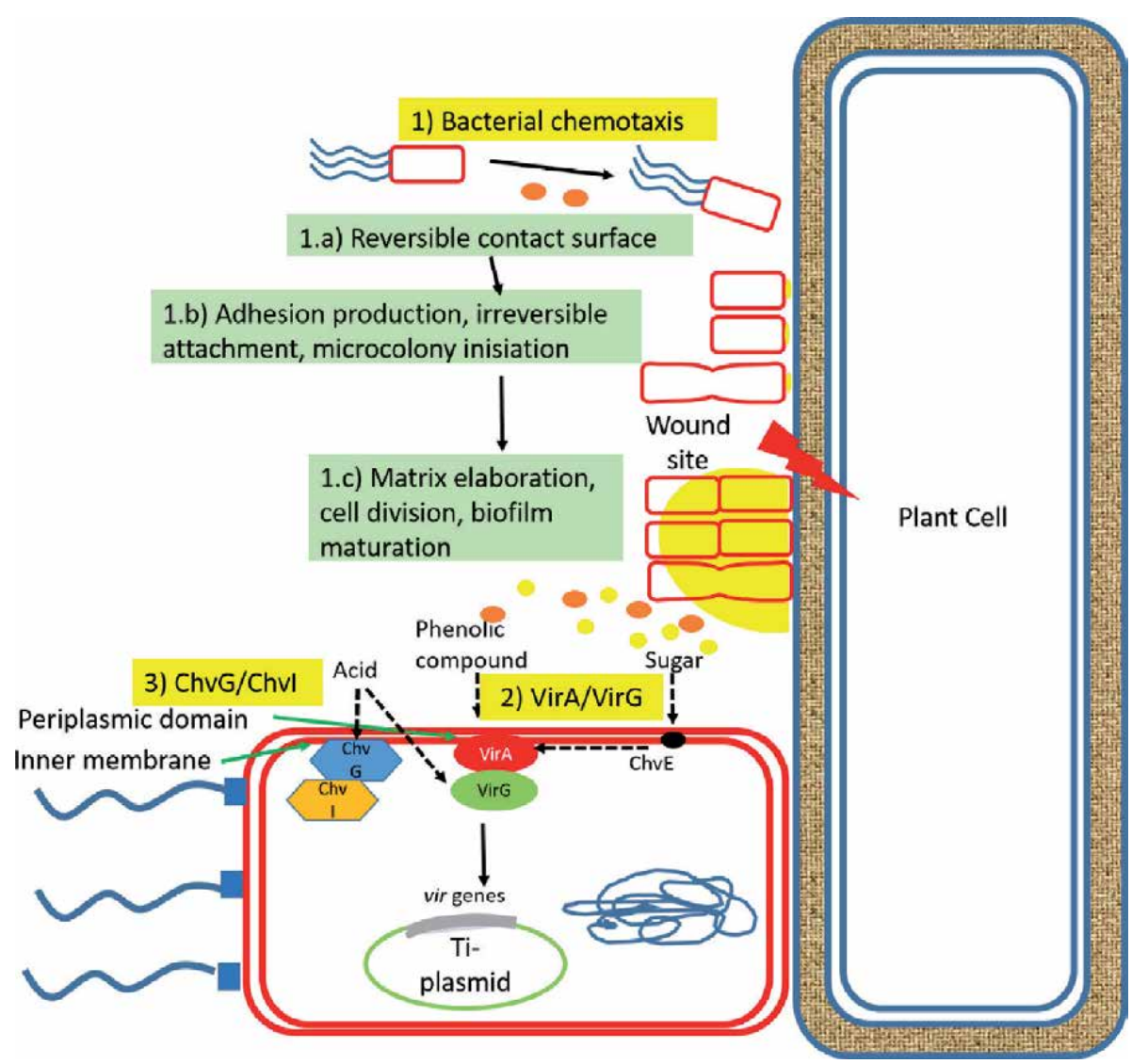

Figure 2.

Schematic representation of A. tumefaciens signal recognition mechanism, modified from [26].

the "overdrive" sequence near the right border of T-DNA (Figure 1) through its C-terminal ribbon-helix-helix DNA binding fold enhances the number of T-strand molecules [30, 31]. The right fraction of the $25 \mathrm{~kb}$ terminus sequence of T-DNA determines the director of DNA transfer [32] (Figure 3).

\subsubsection{T-DNA traveling}

The T-DNA traveling to the host cannot separate from the role of VirD2 and VirE2. Both VirD2 and VirE2 have the C-terminal nuclear localization signal (NLS) sequence that piloted VirD2/T-strand to the host nucleus [33]. VirD2/T-strand, a rodlike structure, exits bacterial cells through Ti-pilus, type IV secretion system (T4SS), which is assembled by 11 VirB and VirD4 proteins [34]. The hydrophilic protein VirE2 is accumulated in the bacterial cytoplasm and translocated into the host cell through clathrin-mediated endocytosis. Besides helping transport the T-strand, VirE2 in the host cytoplasm coats along the T-strand noncovalently and form VirD2/T-strand/VirE2 (termed Ti-complex) to protect it from any nuclease digestive activity [35-37]. Ti-complex in the plant cytoplasm is trafficked to the plant nucleus via the endoplasmic reticulum network inside the plant cytoplasm (Figure 4) [24].

\subsubsection{T-DNA integration}

T-DNA integration followed by transgene expression is the final and crucial stage in the genetic transformation mediated by Agrobacterium. The molecular 


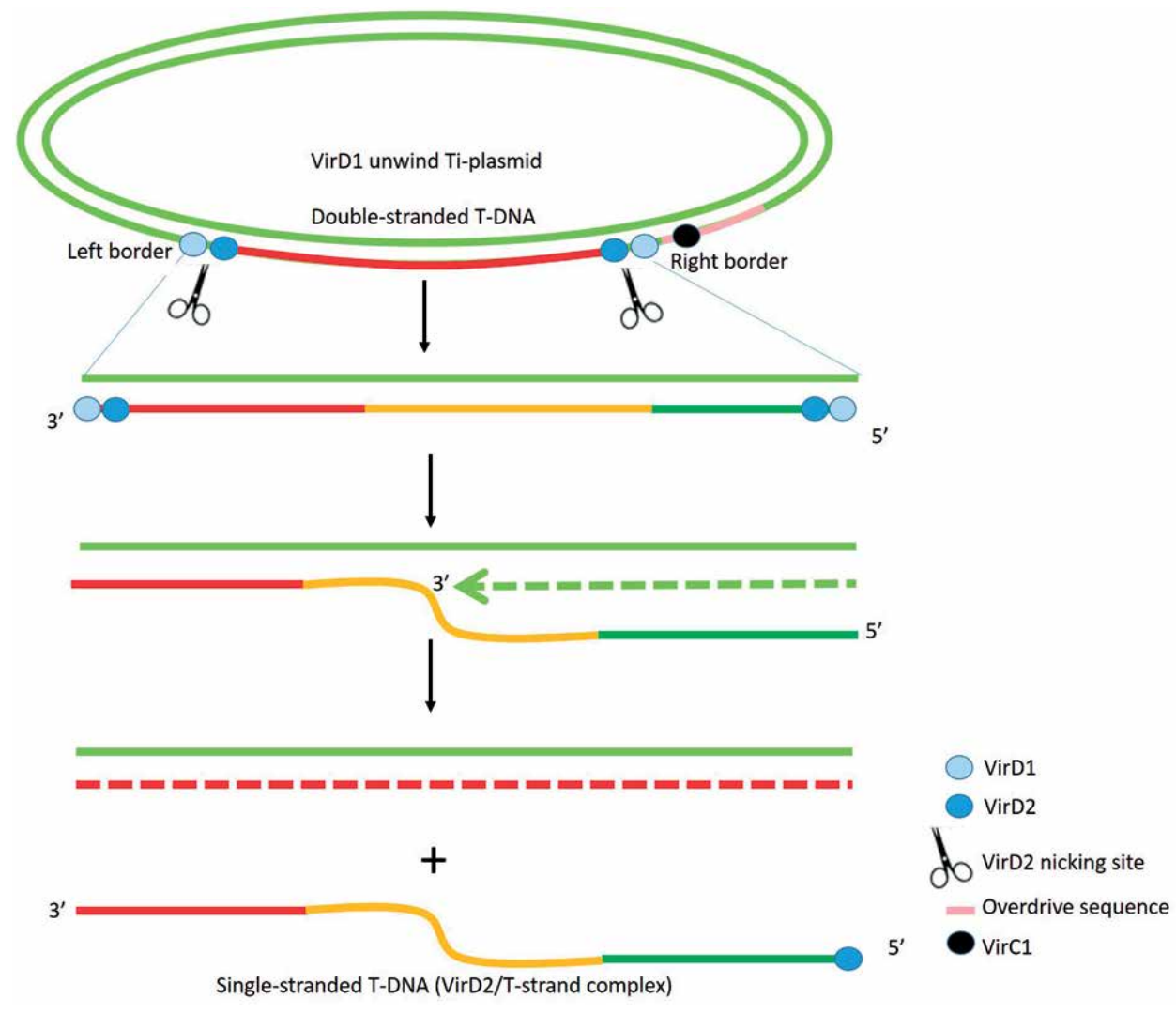

Figure 3.

T-strand generation from T-DNA, modified from [29].

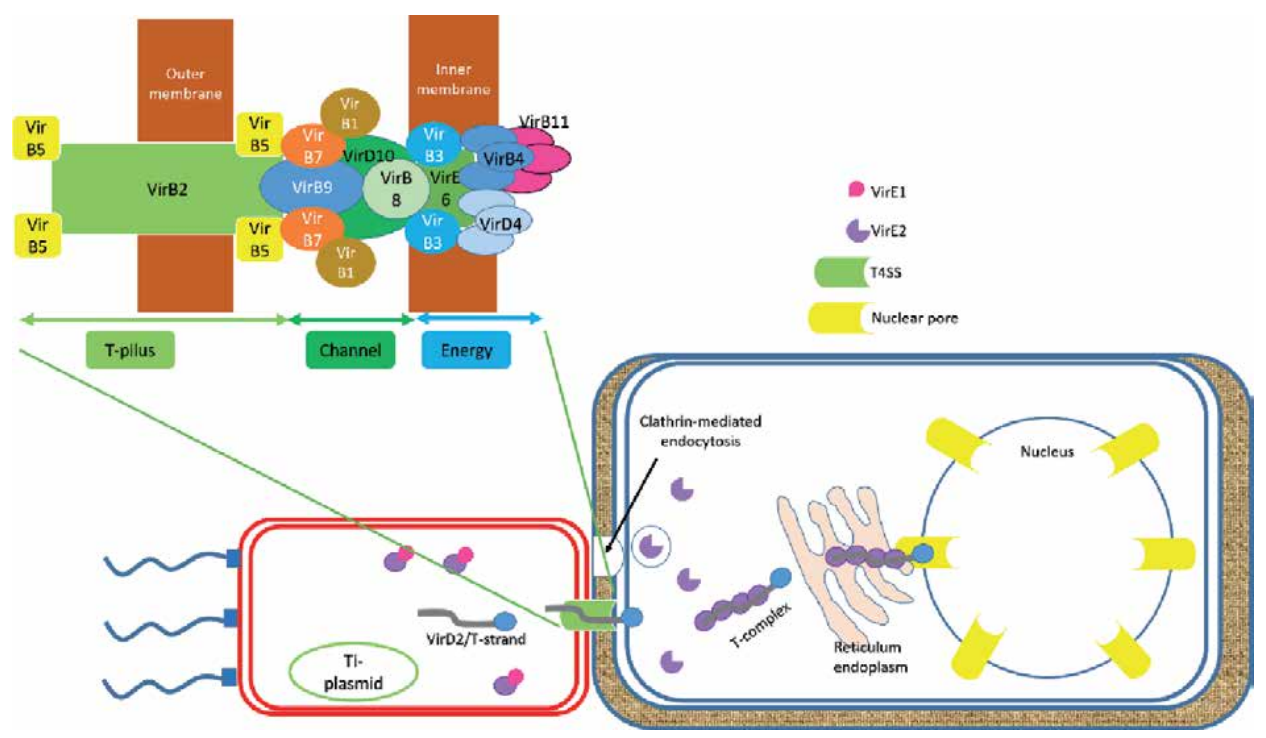

Figure 4 .

T-complex traveling, modified from [38].

mechanism of T-DNA integration into host plant genome actually is still not fully understood. T-DNA integration occurs at random sites, not preferentially in transcriptional active or hypomethylated regions of the plant genome. Some important 
genes in the T-DNA integration process are limited to genes related to chromatin formation and histone modification [39].

VirE2 may play a role in T-strand targeting to chromatin by binding to the bZIP transcription factor VirE2 interacting protein 1 (VIP1). VIP1 mediates the association of VirE2/single-strand DNA with mononucleosomes, a unit of chromatin in the nucleus [39]. When T-complex arrived in the plant nucleus, its protein component should be disassembled by the ubiquitin-proteasome system so that the T-strand can be exposed. T-complex disassembling process and VirE2 degradation are assisted by $\operatorname{VirF}[40,41]$.

VirD2 has no ligation activity, so T-strands are not likely to join directly with the host genome. Possibly, the host DNA polymerase copies the T-strand to form a double-stranded T-DNA, and then it joins with the site breaks of DNA host plant that it is caused by environmental stress due to Agrobacteria incubation or normal metabolic processes. Non-homologous end joining (NHEJ) as a way of repairing broken double-stranded DNA is proposed as the main pathway of bacterial plant DNA integration. NHEJ only requires little or no sequence homology on the damaged part, although in fact there are microhomology between the T-DNA and the integration points on the host chromosome [42] (Figure 5).

\subsubsection{T-DNA expression}

Bacterial T-DNA that integrates with plant genome cells faces two possible fates. First, the T-DNA is expressed, in various levels. Second, the T-DNA is only

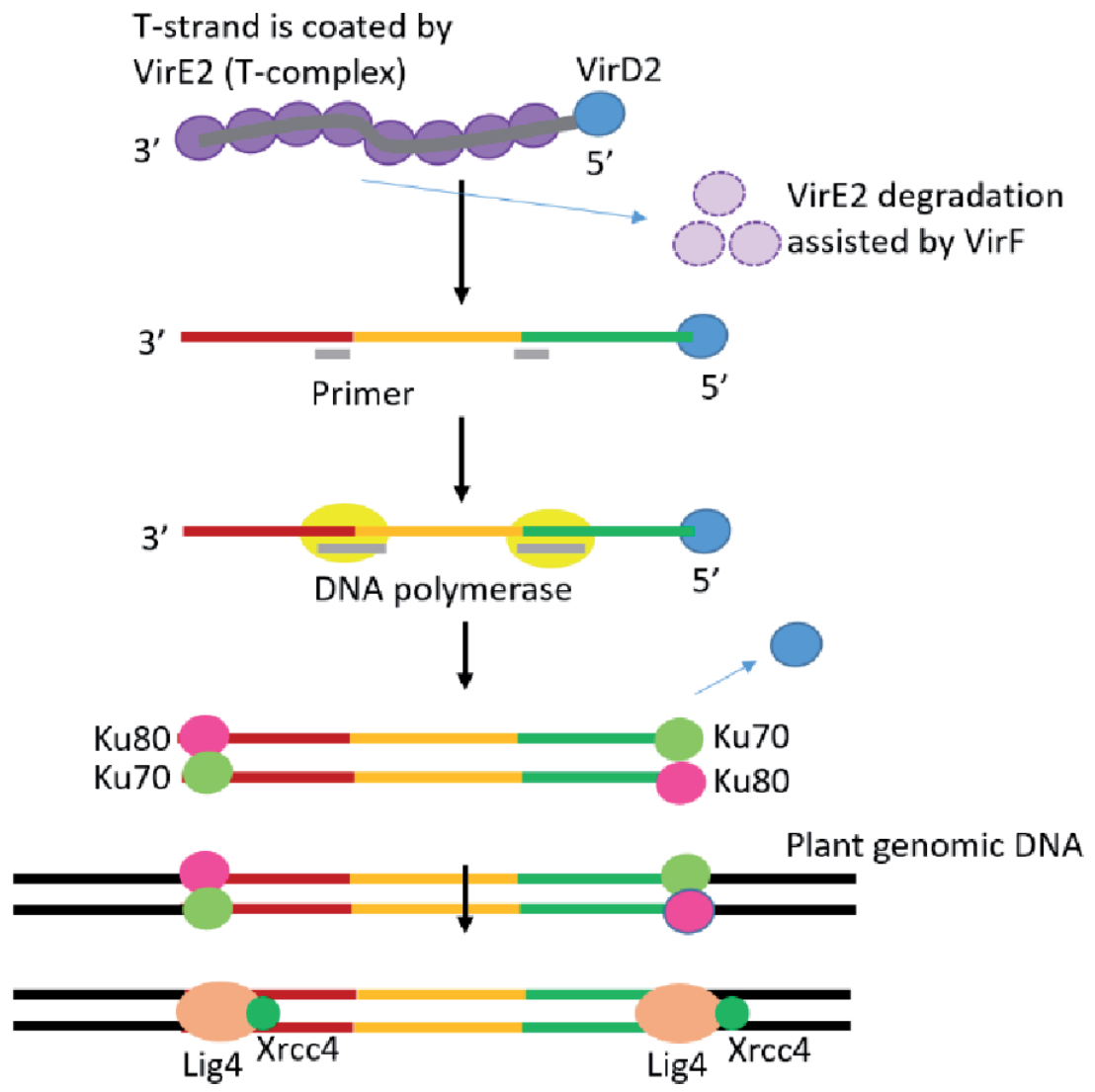

Figure 5.

T-DNA integration, modified from [42]. 
integrated but cannot be expressed. A broad range of transgene expression, from very high to totally silent, depends on species [12].

The expression on auxin and cytokinin coding genes in T-DNA causes the accumulation of both phytohormones. Phytohormone ratio abnormalities bring plant cell to uncontrolled cell proliferation, leading to tumor growth. The expression of opine synthesis coding genes produces opine-the type depends on bacterial strain, an exclusive nutrition for Agrobacterium. In young tissue, swelling is observed from the fourth or fifth day after bacterial inoculation, well-developed in a month, and growing rapidly until it reaches an inch or two in diameter for several months [10]. The overall mechanism of AMT is summarized in Figure 6.

\subsection{Agrobacterium-mediated transformation}

\subsubsection{The engineered A. tumefaciens Ti-plasmid}

The wild-type Ti-plasmids are not suitable for being gene vectors because the T-DNA has oncogenes that cause tumor growth in host cells. Construction disarmed Ti-plasmid by deletion of oncogenes, and opine biosynthetic coding gene makes the plasmid non-oncogenic, the $25 \mathrm{bp}$ of each repeat border sequence remaining. The promise of AMT relies on the substitution of T-DNA by any foreign DNA sequence so that $A$. tumefaciens can be a "vehicle" in insertion gene(s) of interest that are transmissible to the progeny $[18,43]$. Selectable marker genes are inserted into the T-DNA in order to distinguish the transformed cells from normal cells, tandem with experimental transgenes. Some herbicide resistance markers that are commonly used are phosphinothricin, chlorsulfuron, sulfonamide, and glyphosate. The insertion of bacterial selectable marker, such as trimethoprim, streptomycin, spectinomycin, sulfonamides, bleomycin, hygromycin, kanamycin, neomycin, or gentamicin, evaluates the uptake engineered plasmid to bacterial cell [8].

Disarmed Ti-plasmid is difficult to be manipulated in vitro due to its large size. Since the virulence genes may act in trans on the T-DNA sequences in the same cell, it was transferred to small independently plasmid that has origin of replication for Agrobacterium, called "helper vector." In addition, the elimination of virulence gene causes the Ti-plasmid to accommodate longer transgene. Furthermore, scientist constructs the binary vector, so called because it is designed to be replicate in multiple host (E. coli and A. tumefaciens). The binary vector consist of left and right borders, origin of replication for multiple host, selectable marker genes, and gene(s) of interest. This engineered plasmid is now used in plant genetic transformation.

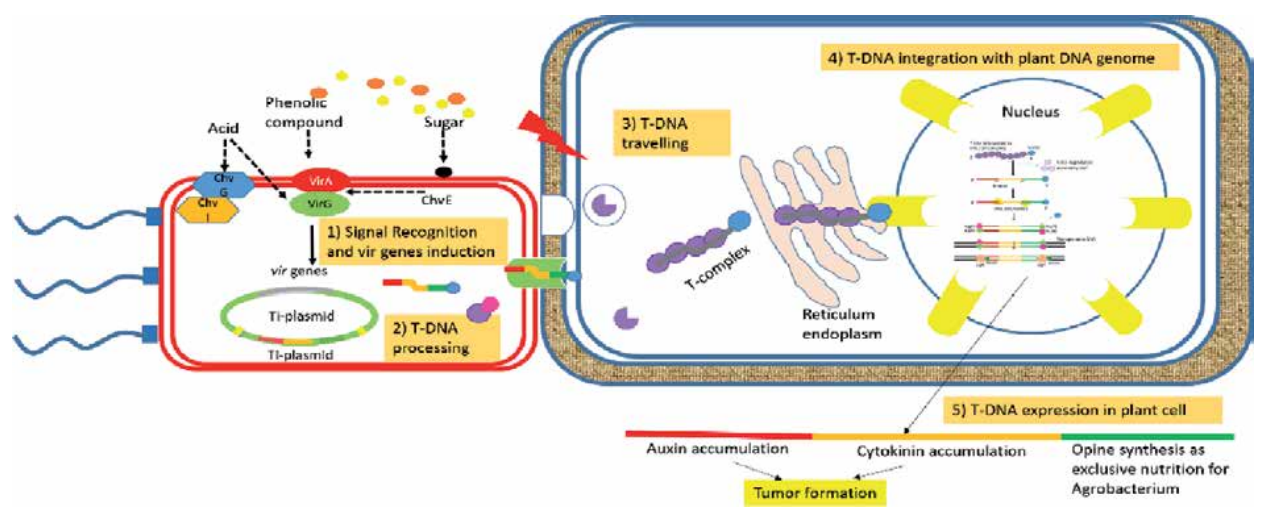

Figure 6.

Overall mechanism schematic of AMT. 


\subsubsection{Agrobacterium-mediated transformation protocol}

AMT is a general method for genetic modification in many plant species. It is because it allows efficient insertion of stable, un-rearranged, single-copy sequences into plant genome. Two critical points for successful transformation were indicated: the use of actively dividing embryonic callus cells derived from the scutella of mature seeds as the starting material and the addition of a phenolic compound, acetosyringone, in the cocultivation steps [44, 45]. Moreover, Cheng et al. reported that there is no significant difference in the transformation efficiencies between immature embryos, pre-cultured ones, and embryogenic callus [46].

Several protocols of AMT have been reported either in Monocotyledoneae or Dicotyledoneae plants. In general, Agrobacterium-based method was used for transgenic plant. The protocol consists of seven steps, which can be briefly summarized as follows: stage (I) preparation of sterilize seed or samples and inoculum; stage (II) explant preparation, infection, and cocultivation with $A$. tumefaciens; stage (III) selection; stage (IV) regeneration; stage (V) acclimatization and molecular identification of $\mathrm{T}_{0}$; stage (VI) cultivation and self-crossing of $\mathrm{T}_{0}$; and stage (VII) $\mathrm{T}_{1}$ plant analysis (Figure 7).

\subsubsection{Preparation of sterilize seed or samples and inoculum}

Immature embryo was a common sample that is used for transformation. Some experience reported that transformation efficiencies depend on the genotype or variety $[47,48]$. To obtain the immature embryo, seed is planted in sterile media (such as husk, compost, mixed soil, etc.) and grown in environmentally controlled growth rooms. Immature embryo is harvested after pollination, but it depends on the species. On the other hand, callus is also produce from hypocotyl or cotyledon explants.

Inoculum is prepared by culture $A$. tumefaciens strain that contains appropriate antibiotics. The bacteria are grown with a loop and suspend in specific media such as LB, LS-inf-AS medium. Inoculum should be prepared fresh. In some

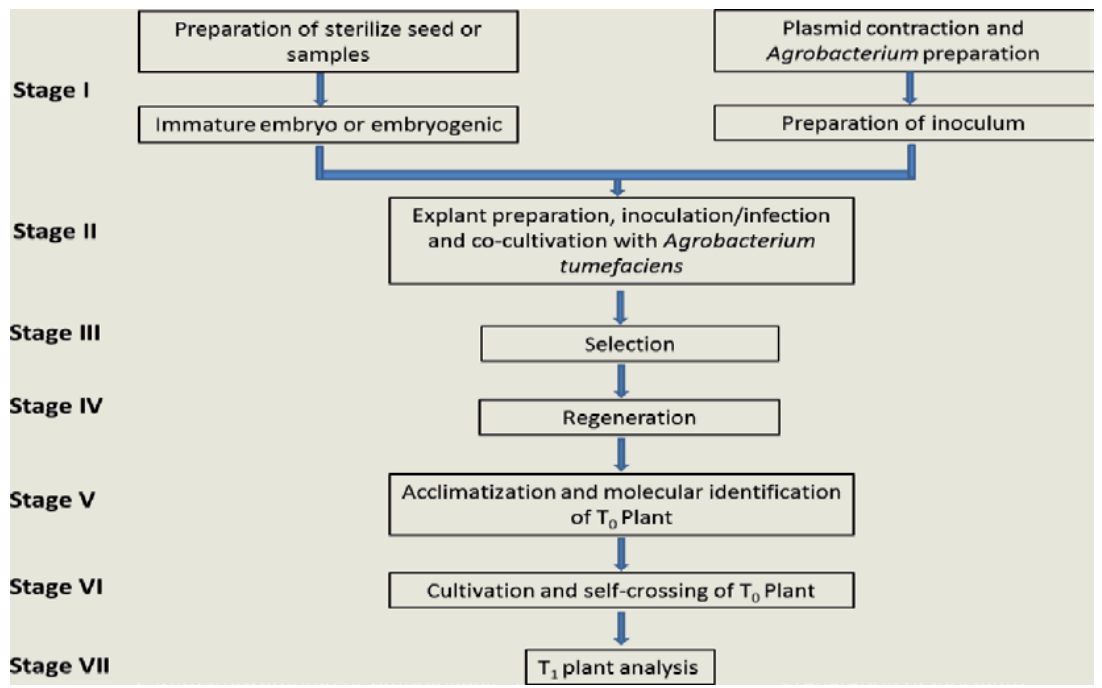

Figure 7.

The protocol of Agrobacterium-mediated transformation. 
cases, the growth of $A$.tumefaciens in liquid culture before transformation is not necessary. On the other hand, the A. tumefaciens preparation and plasmid construction are able to follow the commercial plasmid and $A$. tumefaciens preparation.

\subsubsection{Explant preparation, infection, and cocultivation with A. tumefaciens}

The embryonic, immature embryo or callus is able to be used as the explants. The explant should be sterilized before the infection or transformation process. Both of the suspension of the embryos and bacteria are transferred to the new plate or empty petri dish. After wrapping the petri dish, the cocultivation step follows by incubating in the dark at $24-29^{\circ} \mathrm{C}$ for $2-7$ days, depending on the species. The A. tumefaciens concentration and the infection time were found to be important factors in preventing explant turning necrosis and improving transformation efficiency. We can follow some recommendation from several protocols for specific species.

\subsubsection{Selection}

Selection is one of the critical factors in the success of transformation. The process of selection can be occurred after the stage of transformation, regeneration, or on $\mathrm{T}_{0}$ and $\mathrm{T}_{1}$ plant. Moreover, antibiotic selection is one of the methods to check the successful transformation. In addition to antibiotic selection, PCR should be used to confirm the presence of the targeted transgene in each transformant at each generation.

\subsubsection{Regeneration}

Regeneration of transformed plants occurred after the proliferation. The shoots grown out from the proliferation explants is pulled out and placed in a new medium. Generally, the regeneration stage is following the in vitro propagation methods which are divided into shoot regeneration and selection, cut and recut shoot regeneration, and root regeneration.

\subsubsection{Acclimatization and molecular identification of $T_{0}$}

The acclimatization of $\mathrm{T}_{0}$ can occur after the roots grow strongly. The transgenic $\mathrm{T}_{0}$ plant can be grown directly in a soil or mixed media under the environmental controlled or green house.

\subsubsection{Cultivation and self-crossing of $T_{0}$}

The primary transformant $\left(\mathrm{T}_{0}\right)$ was obtained by A. tumefaciens transformation. After the study of transgene inheritance in successive generation, $\mathrm{T}_{1}$ seeds are produced by self-crossing pollination of the primary transformant $\left(\mathrm{T}_{0}\right)$. The process of cultivation occurred in the greenhouse. The seed of primary transformant $\left(\mathrm{T}_{0}\right)$ is harvested from $\mathrm{T}_{0}$ plant.

\subsubsection{7 $T_{1}$ plant analysis}

$\mathrm{T}_{1}$ plant is the plant that obtained from the harvested seed of $\mathrm{T}_{0}$ plant. The analysis of $\mathrm{T}_{1}$ plant are referring to the morphological or physiological expression of the specific gene which is inserted. 


\section{Conclusions}

Currently, AMT become a common tool for genetic engineering. The mechanism of AMT was affected by several factors and also depends on the species. On the other hand, several Agrobacterium and plasmid have been commercialized, and it was accelerating plant breeding technology. This chapter gave brief information related to AMT mechanism, including the history of crown gall disease caused by $A$. tumefaciens, the natural pathogenesis of A.tumefaciens, and the general protocol of Agrobacterium-mediated transformation in plants.

\section{Author details}

Risha Amilia Pratiwi* and Muhammad Imam Surya

Cibodas Botanical Garden - Research Center for Plant Conservation and Botanic

Gardens, Indonesian Institute of Sciences, Sindanglaya, Cipanas-Cianjur, Indonesia

*Address all correspondence to: risha.amilia.pratiwi@lipi.go.id

\section{IntechOpen}

(C) 2020 The Author(s). Licensee IntechOpen. This chapter is distributed under the terms of the Creative Commons Attribution License (http://creativecommons.org/licenses/ by/3.0), which permits unrestricted use, distribution, and reproduction in any medium, provided the original work is properly cited. (cc) BY 


\section{References}

[1] Seth MK. Trees and their economic importance. The Botanical Review. 2003;69(4):321-376

[2] Hallauer AR. Evolution of plant breeding. Crop Breeding and Applied Biotechnology. 2011;11(3):197-206

[3] Breseghello F, Coelho ASG.

Traditional and modern plant breeding methods with examples in rice (Oryza sativa L.). Journal of Agricultural and Food Chemistry. 2013;61(35):8277-8286

[4] Prohens J. Plant breeding: A success story to be continued thanks to the advances in genomics. Frontiers in Plant Science. 2011;2(51):1-3

[5] Lim J-H, Yang H-J, Jung K-H, Yoo S-C, Paek N-C. Quantitative trait locus mapping and candidate gene analysis for plant architecture traits using whole genome re-sequencing in rice. Molecules and Cells. 2014;37(2):149-160

[6] Chung YS, Choi SC, Jun T-H, Kim C. Genotyping-by-sequencing: A promising tool for plant genetics research and breeding. Horticulture, Environment and Biotechnology. 2017;58(5):425-431

[7] Keeling PJ, Palmer JD. Horizontal gene transfer in eukaryotic evolution. Nature Reviews. Genetics. 2008;9(8):605-618

[8] Matveeva TV, Lutova LA. Horizontal gene transfer from Agrobacterium to plants. Frontiers in Plant Science. 2014;5(326):1-11

[9] Montoya AL. Octopine and nopaline metabolism in Agrobacterium tumefaciens and crown gall tumor cells: Role of plasmid genes. Journal of Bacteriology. 1977;129:7

[10] Smith EF, Townsend CO. A planttumor of bacterial origin. Science. 1907;25(643):671-673
[11] Conn HJ. Validity of the genus Alcaligenes. Journal of Bacteriology. 1942;44(3):353-360

[12] Primrose SB, Twyman RM.

Principles of Gene Manipulation and Genomics. 7th ed. Malden, MA, Oxford: Blackwell Pub; 2006. 644p

[13] White PR, Braun AC. Crown gall production by bacteria-free tumor tissues. Science. 1941;94(2436):239-241

[14] Braun AC. Thermal studies on the factors responsible for tumor initiation in crown gall. American Journal of Botany. 1947;34(4):234-240

[15] Zaenen I, van Larebeke N, Teuchy H, van Montagu M, Schell J. Supercoiled circular DNA in crown-gall inducing Agrobacterium strains. Journal of Molecular Biology. 1974;86(1):109-127

[16] Ledeboer AM, Krol AJM, Dons JJM, Spier F, Schilperoort RA, Zaenen I, et al. On the isolation of TI-plasmid from Agrobacterium tumefaciens. Nucleic Acids Research. 1976;3(2):449-463

[17] Koncz C, De Greve H, André D, Deboeck F, Van Montagu M, Schell J. The opine synthase genes carried by $\mathrm{Ti}$ plasmids contain all signals necessary for expression in plants. The EMBO Journal. 1983;2(9):1597-1603

[18] Chilton M-D, Drummond MH, Merlo DJ, Sciaky D, Montoya AL, Gordon MP, et al. Stable incorporation of plasmid DNA into higher plant cells: The molecular basis of crown gall tumorigenesis. Cell. 1977;11(2):263-271

[19] Chilton M-D, Saiki RK, Yadav N, Gordon MP, Quetier F. T-DNA from Agrobacterium Ti plasmid is in the nuclear DNA fraction of crown gall tumor cells. Proceedings of the National Academy of Sciences 
of the United States of America. 1980;77(7):4060-4064

[20] Garfinkel D. Genetic analysis of crown gall: Fine structure map of the T-DNA by site-directed mutagenesis. Cell. 1981;27(1):143-153

[21] Veluthambi K, Jayaswal RK, Gelvin SB. Virulence genes a, G, and $\mathrm{D}$ mediate the double-stranded border cleavage of T-DNA from the Agrobacterium Ti plasmid. Proceedings of the National Academy of Sciences of the United States of America. 1987;84(7):1881-1885

[22] Hooykaas PJJ, Melchers LS, Rodenburg CW, van Veen RJM. Regulation of the agrobacterium virulence genes by plant factors. In: Lugtenberg BJJ, editor. Signal Molecules in Plants and Plant-Microbe Interactions. NATO ASI Series (Series $\mathrm{H}$ : Cell Biology). Berlin, Heidelberg: Springer; 1989. pp. 153-160

[23] Păcurar DI, Thordal-Christensen H, Păcurar ML, Pamfil D, Botez C, Bellini C. Agrobacterium tumefaciens: From crown gall tumors to genetic transformation. Physiological and Molecular Plant Pathology. 2011;76(2):76-81

[24] Guo M, Ye J, Gao D, Xu N, Yang J. Agrobacterium-mediated horizontal gene transfer: Mechanism, biotechnological application, potential risk and forestalling strategy. Biotechnology Advances. 2019;37(1):259-270

[25] Stachel SE. VirA and virG control the plant-induced activation of the T-DNA transfer process of $A$. tumefaciens. Cell. 1966;46:325-333

[26] Heindl JE, Wang Y, Heckel BC, Mohari B, Feirer N, Fuqua C. Mechanisms and regulation of surface interactions and biofilm formation in Agrobacterium. Frontiers in Plant Science. 2014;5(176):1-21
[27] Melchers LS, Regensburg-Tuïnk TJ, Bourret RB, Sedee NJ, Schilperoort RA, Hooykaas PJ. Membrane topology and functional analysis of the sensory protein VirA of Agrobacterium tumefaciens. The EMBO Journal. 1989;8(7):1919-1925

[28] Shimoda N, Toyoda-Yamamoto A, Nagamine J, Usami S, Katayama M, Sakagami Y, et al. Control of expression of Agrobacterium vir genes by synergistic actions of phenolic signal molecules and monosaccharides. Proceedings of the National Academy of Sciences of the United States of America. 1990;87(17):6684-6688

[29] Zambryski P, Tempe J, Schell J. Transfer and function of T-DNA genes from Agrobacterium $\mathrm{Ti}$ and Ri plasmids in plants. Cell. 1989;56(2):193-201

[30] Toro N, Datta A, Carmi OA, Young C, Prusti RK, Nester EW. The Agrobacterium tumefaciens virCI gene product binds to overdrive, a T-DNA transfer enhancer. Journal of Bacteriology. 1989;171(12):6845-6849

[31] Lu J, den Dulk-Ras A, Hooykaas PJJ, Glover JNM. Agrobacterium tumefaciens VirC2 enhances T-DNA transfer and virulence through its C-terminal ribbon-helix-helix DNA-binding fold. Proceedings of the National Academy of Sciences. 2009;106(24):9643-9648

[32] Wang K, Herrera-Estrella L, Montagu MV. Right 25 bp terminus sequence of the nopaline T-DNA is essential for and determines direction of DNA transfer from Agrobacterium to the plant genome. Cell. 1984;38:455-462

[33] Shurvinton CE, Hodges L, Ream W. A nuclear localization signal and the C-terminal omega sequence in the Agrobacterium tumefaciens VirD2 endonuclease are important for tumor formation. Proceedings of the National Academy of Sciences 
of the United States of America. 1992;89(24):11837-11841

[34] Baron C, Zambryski PC. Plant transformation: A pilus in Agrobacterium T-DNA transfer. Current Biology. 1996;6(12):1567-1569

[35] Gietl C, Koukolicova-Nicola Z, Hohn B. Mobilization of T-DNA from agrobacterium to plant cells involves a protein that binds single-stranded DNA. Proceedings of the National Academy of Sciences of the United States of America. 1987;84:9006-9010

[36] Christie PJ, Ward JE, Winans SC, Nester EW. The Agrobacterium tumefaciens virE2 gene product is a single-stranded-DNA-binding protein that associates with T-DNA. Journal of Bacteriology. 1988;170(6):2659-2667

[37] Guo M, Ye J, Gao D, Xu N. Yang Jing. Agrobacterium-mediated horizontal gene transfer: Mechanism, biotechnological application, potential risk and forestalling strategy. Biotechnology Advances. 2018;37(1):259-270

[38] Ananiadou S, Sullivan D, Black W, Levow GA, Gillespie JJ, Mao C, et al. Named entity recognition for bacterial type IV secretion systems. PLoS One. 2011;6(3):1-10

[39] Gelvin SB. Integration of Agrobacterium T-DNA into the plant genome. Annual Review of Genetics. 2017;51(1):195-217

[40] Lacroix B, Citovsky V.

Beyond Agrobacterium-Mediated transformation: Horizontal gene transfer from bacteria to eukaryotes. In: Gelvin S, editor. Agrobacterium Biology. Current Topics in Microbiology and Immunology. Cham: Springer; 2018. pp. 443-462

[41] Lacroix B, Citovsky V. Pathways of DNA transfer to plants from
Agrobacterium tumefaciens and related bacterial species. Annual Review of Phytopathology. 2019;57(1):231-251

[42] Haika H, Nishizawa-Yokoi A, Toki S. The non-homologous endjoining pathway is involved in stable transformation in rice. Frontiers in Plant Science. 2014;5(560):1-5

[43] David C, Chilton M, Tempé J. Conservation of T-DNA in plants regenerated from hairy root cultures. Nature Biotechnology. 1984;2:73-76

[44] Hiei Y, Komari T, Kubo T.

Transformation of rice mediated by Agrobacterium tumefaciens. Plant Molecular Biology. 1997;35:205-218

[45] Hiei Y, Ohta S, Komari T, Kumashiro T. Efficient transformation of rice (Oryza sativa L.) mediated by Agrobacterium and sequence analysis of the boundaries of the T-DNA. The Plant Journal. 1994;6(2):271-282

[46] Cheng M, Fry JE, Pang S, Zhou H, Hironaka CM, Duncan DR, et al. Genetic transformation of wheat mediated by Agrobacterium tumefaciens. Plant Physiology. 1997;115(3):971-980

[47] Jones HD, Doherty A, Wu H.

Review of methodologies and a protocol for the agrobacterium-mediated transformation of wheat. Nature Protocols. 2006;1(6):2796-2802

[48] Nishimura A, Aichi I, Matsuoka M. A protocol for Agrobacterium-mediated transformation in rice. Nature Protocols. 2006;1(6):2796-2802 


\title{
Grapevine Improvement through Biotechnology
}

\author{
Devaiah Kambiranda, James Obuya and Janana Snowden
}

\begin{abstract}
Grapevine cultivation is increasing worldwide as people realize the benefits of grape and wine consumption. To improve yield and enhance the quality of grapes, biotechnology research plays an ever-increasing role. In recent years, the sequencing of multiple grape genomes has led to increased vibrant research initiatives on grape improvement. These novel approaches include those related to the application of transgenic technology toward the improvement of grape varieties. These advancements include the development of molecular markers for valuable traits, improved plant transformation systems, genetic engineering to enhance disease tolerance in grape cultivars, and the identification of flavor and aroma components to improve the enological quality of grapes. Some of the results obtained by various researchers have direct application, whereas others are yet to gain direct application in grape quality improvement, although such techniques possess potential qualities, which can be exploited for genetic breeding of Vitis species. This chapter highlights selected advancements in grape biotechnology from recently reported research activities.
\end{abstract}

Keywords: grapevine, transgenic, biotechnology, Vitis spp., cultivars

\section{Introduction}

Worldwide, grapes are one of the most widely cultivated fruit crops, encompassing 6.9 million hectares of arable land from which 74.3 million metric tons were produced in 2017 [1]. From the 2017 data, grapes ranked third among crops such as bananas, apples, and oranges that produced 113.9, 83.1, and 73.3 million metric tons, respectively. Since most of the harvested grapes are usually fermented into wine, it is suggested that its economic potential is greater than those of other comparative commodity crops. For example, wine sales from California alone in 2018 generated approximately $\$ 40$ billion in sales [2]. According to 2015 statistics, the California wine industry contributed $\$ 57.6$ and $\$ 114$ billion to both the state and the US economies, respectively. The three major uses for grapes are winemaking, fresh fruit (table grapes), and dried fruit (raisins) production. The products derived from grapes or winemaking include grape juice, jelly products, ethanol, vinegar, grape seed oil, tartaric acid, and fertilizer.

Potential health benefits of certain grape-derived antioxidant compounds (polyphenols, resveratrol) have also contributed to increased research to investigate its compounds for their nutraceutical value. Grape extracts are used food additive, cosmetic, and pharmaceutical industries. Statistics from winemaking is steeped in history and tradition-perhaps more than any other food or beverage industry. 
From the soil, climate, and harvesting of grapes to the crushing and aging processes, painstaking attention to detail dictates the flavor, bouquet, and the overall sensory experience of the final product. Hence, it may not be a surprise to learn that the grape industry is increasingly looking toward biotechnology for new opportunities to improve strategies for combating crop diseases and lower production costs for producing healthier and more flavorful products.

\subsection{Historical development of grape biotechnology research}

Grape breeding started very early, first for wine grapes and, by the end of the nineteenth century, for table grapes. Breeding for rootstocks started toward the end of the nineteenth century after the era of Phylloxera devastations of European vineyards. During the twentieth century, active breeding programs for table grapes were initiated in the USA, both by the USDA and by various institutions, which resulted in many new cultivars with improved characteristics. The original cultivars released in the USA led to the proliferation of table grape industry worldwide. Since then, several breeding programs have been established in Europe, South Africa, Israel, Argentina, Chile, and several other countries.

Globally, table grape production represents $27 \%$ of the 750,000 hectares planted with this species. Although table grape production in North and South America mainly represents c.a. $18 \%$ of the total world production, North America accounts for almost $50 \%$ of the global exports. Main exporters are Chile and Italy, followed by the USA, South Africa, and Mexico. Of the thousands of existing cultivars, only about 20 are grown for fresh consumption, with "Sultanina" ("Sultani," "Sultana," "Kishmish," or "Thompson Seedless") representing about $40 \%$ of the grapes grown for fresh consumption. This cultivar has been used extensively as a parental line for the development of new cultivars, such as "Flame Seedless" and "Crimson Seedless." These varieties, together with "Red Globe" (an important seeded cultivar due to its excellent postharvest life, high productivity, and public acceptance), are some of the most cultivated worldwide. During the last decade, new biological and genetic information are available to plant breeders, particularly in the area of biotechnology.

Biotechnological tools have been incorporated into breeding programs focused on the improvement of genetic diversity [3, 4]; fingerprinting applications based on codominant markers; quantitative trait loci (QTL) mapping and identification of candidate genes linked to QTLs for quality traits; development of cDNA libraries designed for the identification of genes involved in plant and berry development and host-pathogen interactions; and finally, the establishment of a genetic transformation platform available for the introduction of genes of interest as well as for the evaluation of gene function(s) using the grapevine as a model for woody plant species. The grape genome project was started in 2005 with collaborators in France and Italy within the framework of the International Grape Genome Project (IGGP).

The grape genome is attractive to genomic research due to its diploid chromosome with a small genome size of $475-500 \mathrm{Mb}$. The economic importance of the Vitis family worldwide informed the initiation of the genome project since its biology was poorly understood. Although for centuries, the industry contributed to the establishment of several wine production centers worldwide, little is known on how grapevines usually responded to and/or related with their surroundings, including their ability to cope under variable environmental stressors, such as pests and diseases, as well as the prevailing environmental conditions. 


\section{Grapevine breeding}

Most breeding programs initially were publicly funded, but nowadays many of them are privately owned. Mostly new cultivars are protected by intellectual property rights, and, hence, growers need to pay royalties for their use or they may not gain access to some of the cultivars stored in closed commercialized "entities." Due to this new scenario, many countries and companies started their own private breeding programs. In 1988, the Chilean Institute for Agricultural Research started a breeding program to develop new table grape cultivars with emphasis on seedless grapes, disease resistance, and postharvest life [5]. Since the production of seedless cultivars, crosses were made among the seedless cultivars followed by in vitro embryo rescue. Early in the program, researchers have realized that certain cultivars were more efficient for embryo rescue. For example, in "Ruby Seedless" and "Red Seedless," $68 \%$ and $40 \%$ of the embryos, respectively, could be rescued, but with "Superior Seedless" or "Black Seedless," less than $30 \%$ of the embryos could be rescued [6].

As with other crops, plant breeders faced difficult task to develop high-vigor cultivars that would combine high yield with good quality traits. Quality in table grapes is associated with genetic factors, but also with environmental factors, most of which can be managed by different agricultural practices which can influence yield. Quality traits in table grapes are also influenced by consumer preferences, an important factor to be considered by grape breeders. Good berry quality characteristics include seedlessness, berry size, skin thickness, uniformity, aroma, firmness, flavor, texture, etc. present during harvest and after prolonged storage [7, 8]. More recently, characters such as the presence of nutritional components and nutraceutical determinants have gained increased traction. Postharvest traits of importance include resistance to prolonged storage and transport, rachis tolerance to oxidation and dehydration, low susceptibility of the berries to browning and spotting, as well as resistance to decay.

\subsection{Application of biotechnology research to grapevine breeding and genetics}

Research in grapevine genetics is restrained by the lack of genetic stocks, high heterozygosity, inbreeding depression, large space requirements, and the relatively long juvenile period. In 1957, De Lattin [9] summarized his work on 53 genes identified in Vitis sp. Research on grapevine genetics has intensified since the late 1950s, and yet until 1990 surprisingly only a few additional genes were located [10]. Molecular markers have facilitated research in Vitis genetics. It is now possible to map the grapevine genome and to create unique DNA profiles for each genotype. The first plant linkage maps were based on visually scored morphological markers. Later, isozymes - at least two enzymes with identical function but different structure- and DNA-based markers-which are virtually limited in number [11] were used to create densely saturated maps.

Genetic resources possessing genes for resistance to many fungal diseases were found within Vitis species, and, hence, the transfer of these genes to V. vinifera cultivars has been partially carried out [12]. However, the process takes many years, and it is rather difficult for breeding disease-resistant grapevines with commercial values from interspecific hybrids. Thus, genes that confer resistance to diseases are of special interest in improving and breeding grapevine cultivars.

\subsection{Marker-assisted selection}

Marker-assisted selection can be used for pyramiding genes for resistance. Genetic pyramiding is a process used for the development of new breeding lines 
with homozygous resistance loci and consequently selecting new parental lines with the desired traits. To understand the potential value of molecular markers, it is imperative to identify the major markers. Isozymes have different electrophoretic mobility and, hence, can be visualized following gel electrophoresis. Over 20 polymorphic isozymes have been identified in grapes. Restriction fragment length polymorphisms (RFLPs) can be used for their rapid detection using restriction enzymes and involves cutting genomic DNA molecules at unique nucleotide sequences (restriction sites) yielding DNA fragments with varied sizes. However, identification of RFLPs requires a high concentration of DNA and could be relatively expensive to assay.

Polymerase chain reaction (PCR)-based assays are generally much less expensive and can reveal higher levels of polymorphism $[11,13]$. The selection process of a DNA fragment for amplification involves "primer annealing" in which two primer pairs (5-30 bases long) complementarily bind onto genomic DNA strands in a reaction process. The primer-DNA complex is a critical step for the replication of adjacent DNA sequences by a thermostable polymerase supplied in the reaction mixture.

A commonly used PCR analysis is based on random amplified polymorphic DNA (RAPDs). These markers are based on the occurrence of an inverted pair of 9-11 base repeats (occasionally longer or shorter, as well) as within between 200 and 2000 base pairs. This is a single primer reaction that amplifies one-to-many segments of DNA through PCR. Amplified fragment length polymorphisms (AFLPs) are based on the selective amplification of restriction enzyme-digested DNA fragments. Multiple bands (50-100) are generated during each amplification reaction resulting in random DNA markers. Neither RAPDs nor AFLPs are "anchored," i.e., their primary use is within and not between crosses. On the other hand, several sequence-tagged site (STS) markers are useful as anchoring loci between crosses. The most important of these is a microsatellite, a simple sequence repeat (SSR) marker [11] based on the discovery of repeated sequences in the genome and usually $2-4$ nucleotides in length (e.g., ... (GCC) 17 ...). The bases flanking the repeat sequence are conserved, but the length of the repeat can vary greatly; SSR-specific primers can be readily designed. Each SSR is a single locus with multiple allele sizes.

\subsubsection{RAPD markers}

Genetic analyses have progressed rapidly since the discovery of polymorphic regions or loci with two or more alleles in genomic DNA [14]. Variation in location, copy number, length, and base pair sequence of these highly repetitive DNA regions provide a rich source of markers for unique identification. Random amplified polymorphic DNA analysis has been applied to several aspects of the winemaking process $[15,16]$. Several investigators have attempted to discriminate between grape plant clones utilizing a variety of genetic typing techniques [17-23]. However, Regner et al. [24] utilized SSR, RAPD, and AFLP markers and were successful in detecting differences within clones of the Grüner, Veltliner, Pinot Blanc, Morillion, and Chardonnay varieties. Using RAPD markers, Moreno et al. [25] discriminated between clones of $V$. vinifera to a limited extent.

\subsubsection{Microsatellites}

Microsatellite genotyping requires the determination of the number of repeat units at a given locus in a given cultivar. This is achieved by electrophoretic sizing of the fragment containing the repeat region (the microsatellite allele), which was 
amplified by PCR with primers situated upstream and downstream of the microsatellite DNA. The initial grapevine microsatellite study conducted by Thomas and Scott [26] at CSIRO Plant Industry, Australia, reportedly identified DNA isolated from 26 V. vinifera cultivars and 6 additional Vitis species as well as Muscadinia rotundifolia.

Since then researchers have accumulated microsatellite profiles of hundreds of grapevine cultivars from many different regions. The data is available in public databases (Table 1). Among the 19 chromosomes of grape genome from a homozygous line, PN40024, about 10,948 contained trinucleotide repeats, 4386 had tetranucleotide repeats, and 3347 had penta-nucleotide repeats [27].

\subsubsection{Single-nucleotide polymorphism (SNP)}

Single-nucleotide polymorphism (SNP)-based genetic markers have attracted significant attention when researchers are creating dense genetic linkage maps. SNPs are the most abundant class of polymorphisms, and they provide gene-based markers that may prove useful when identifying candidate genes of interest to be associated with quantitative trait loci. V. vinifera utilizes many SNP-based genetic markers and maps to them a framework of loci defined by SSR markers in the Syrah 3 and Pinot Noir cross. The markers are derived from V. vinifera collections of expressed sequence tags (ESTs) and bacterial artificial chromosome (BAC) end

\begin{tabular}{|c|c|c|c|}
\hline Database name & Physical address & $\begin{array}{l}\text { Internet address of } \\
\text { public databases }\end{array}$ & $\begin{array}{l}\text { Number of } \\
\text { genotypes }\end{array}$ \\
\hline European Vitis Database & $\begin{array}{l}\text { IRZ, Siebeldingen, } \\
\text { Germany }\end{array}$ & $\begin{array}{c}\text { http://www.genres.de/ } \\
\text { eccdb/vitis/ }\end{array}$ & In preparation \\
\hline $\begin{array}{l}\text { Grape Microsatellite } \\
\text { Collection (GMC) }\end{array}$ & $\begin{array}{l}\text { IASMA, San Michele, } \\
\text { Italy }\end{array}$ & Not public & \\
\hline Grape SSR database & $\begin{array}{c}\text { Australian Wine } \\
\text { Research Institute } \\
\text { (AWRI) }\end{array}$ & Not public & \\
\hline $\begin{array}{l}\text { International Vitis Variety } \\
\text { Catalogue }\end{array}$ & $\begin{array}{l}\text { IRZ, Siebeldingen, } \\
\text { Germany }\end{array}$ & $\begin{array}{l}\text { http://www.vivc.bafz.de/ } \\
\text { index.php }\end{array}$ & 46 \\
\hline $\begin{array}{l}\text { SSR profiles (not } \\
\text { searchable) }\end{array}$ & $\begin{array}{l}\text { BOKU, Vienna, } \\
\text { Austria }\end{array}$ & $\begin{array}{c}\text { http://www.boku.ac.at/ } \\
\text { zag/forsch/grapeSSR2.htm }\end{array}$ & 162 \\
\hline $\begin{array}{l}\text { The Bulgarian Plant } \\
\text { Genomics Database }\end{array}$ & $\begin{array}{l}\text { Agrobioinstitute, } \\
\text { Sofia, Bulgaria }\end{array}$ & $\begin{array}{c}\text { http://bulgenom.abi.bg/ } \\
\text { AgroBioInstitute\%20 } \\
\text { Selected.htm }\end{array}$ & 76 \\
\hline The Greek Vitis Database & $\begin{array}{l}\text { University of Crete, } \\
\text { Heraklion, Greece }\end{array}$ & $\begin{array}{l}\text { http://gvd.biology.uoc.gr/ } \\
\text { gvd/index.htm }\end{array}$ & 298 \\
\hline $\begin{array}{l}\text { The Swiss Vitis } \\
\text { Microsatellite Database }\end{array}$ & $\begin{array}{l}\text { University of } \\
\text { Neuchâtel, } \\
\text { Switzerland }\end{array}$ & $\begin{array}{l}\text { http://hydra.unine.ch/ } \\
\text { svmd/ }\end{array}$ & 170 \\
\hline $\begin{array}{l}\text { Ukrainian, Moldovan and } \\
\text { Russian Vitis Database }\end{array}$ & $\begin{array}{l}\text { Magarach Institute, } \\
\text { Yalta, Ukraine }\end{array}$ & Not public & 104 \\
\hline Vitis SSR database & $\begin{array}{c}\text { University of } \\
\text { California, Davis, USA }\end{array}$ & Not public & \\
\hline Vitis SSR database & $\begin{array}{l}\text { INRA Montpellier, } \\
\text { France }\end{array}$ & Not public & \\
\hline
\end{tabular}

Table 1.

Existing public and unpublished databases of grapevine SSR profiles [28]. 
sequences available in the NCBI (with 149,691 EST sequences clustered into 15,194 unigenes and 30,832 BESs (http://www.ncbi.nlm.nih.gov)). In addition, SSR and AFLP markers were employed to increase the number of bridges between genetic and physical map considering specific markers used by the international grapevine community.

In grapes, polymorphic DNA loci are relatively frequent. Salmaso et al. [28] found a single SNP in every $116 \mathrm{bp}$ in the coding regions of 25 genes using ESTderived primers in the analysis of seven $V$. vinifera cultivars. The high percentage of monomorphic regions ( $28 \%$ for EST, $19 \%$ for BES) is quite unexpected when compared with what has been reported in the literature on grape and can be explained in part by the preferential PCR amplification of one allele, which is due to mismatches between the PCR primer and the second allelic template [29]. On the other hand, coding sequences have a higher probability of being monomorphic due to a direct effect of selection in favor of sequence conservation. The addition of SNP-based markers can identify polymorphisms that are easy to locate from a database, which can be useful for evolutionary studies to significantly increase the density of the linkage map. This leads to an improved resource for high-quality mapping of quantitative trait loci, identification of candidate genes, and enhanced map-based gene isolation.

\section{Grape genome sequence and its applications}

The genome project was informed by the realization that the Vitis family is the most economically important crop worldwide due to its high value. However, its developmental biology is still poorly understood. Grape can be a potential model crop because it contains valuable genetic information that can be mined for the improvement of other fruit tree crops. As a result, an International Grape Genome Program (IGGP) was with the objective to sequence the grape genome. Research centers have been established globally in countries leading in grape production, such as France, Italy, Australia, Canada, Chile, Germany, South Africa, Spain, and the United States. Genetically, Vitis species have 38 chromosomes $(n=19)$ with fertile interspecies hybrids.

The first high-quality reference grape genome sequence was obtained from a Pinot Noir clone ENTAV 115, a variety grown in wide range of soil types to produce red and sparkling wines. The reference genome sequence information has been useful toward understanding its overall genetic organization, including the content of genes and the structural components of the DNA of the 19 linkage groups (LGs) of V. vinifera. A whole-genome shotgun sequencing and the Sanger sequencing method generated $12 \times$ coverage of the genome. This has been integrated with sequence reads generated by a scalable, highly parallel sequencing by synthesis (SBS) method with throughput significantly greater than capillary electrophoresis. The assembly has been improved through the addition of $4.2 \times$ coverage, including the addition of bacterial artificial chromosome end sequences that have improved the scaffolding of the sequenced contigs. The $4.2 \times$ coverage provided by SBS was crucial in the identification of polymorphic sites and resulted in closing most of the gaps between DNA contigs. This is the first project that utilized both the longer Sanger and shotgun sequence-based methods to determine the sequence of a large eukaryotic genome.

The estimated genome size of $V$. vinifera Pinot Noir clone ENTAV 115 is at least $500 \mathrm{Mb}$. Genomic sequences corresponding to $477.1 \mathrm{Mb}$ were assembled in 2093 metacontigs, and $435.1 \mathrm{Mb}$ were anchored to the 19 linkage groups. The number of predicted genes and pseudogenes is 28,352 of which $96.1 \%$ were assigned to 
LGs. The assembled grape genome has predicted candidate genes with implicated traits relevant to grapevine cultivation, such as those influencing wine quality via secondary metabolites and those associated with extreme susceptibility of grapes to pathogens.

The NCBI taxonomy web portal for $V$. vinifera contains a summarized data for one of the common species used for wine production. The Ensembl Plants has produced a Grape Gene Index by analyzing the nucleotide sequences deposited at NCBI, and Release $12 \times$ of the index lists 29,971 unique coding genes. The gene ontology and metabolic pathway information for many of these sequences are also available at the TIGR site (http://www.tigr.org/tigr-scripts/tgi/T_index. cgi?Species=grape).

Genetic maps have been produced [33, 61-64], and physical maps are being produced in several laboratories [65] with a consensus map in progress. A grape BAC library is available from the French National Resources Center for Plant Genomics (CNRGV). Affymetrix (http://www.affymetrix.com/index.affx) released a grape array that represents $14,000 \mathrm{~V}$. vinifera transcripts and 1700 transcripts from other Vitis species that can be useful for gene expression analysis.

Qiagen (http://www1.qiagen.com) also released a new grape ( $V$. vinifera) array-ready oligo set contains 14,562 probes of 70-mers representing grape gene transcripts. Probe design for the grape oligo set is based on sequence information from TIGR's Grape Gene Index (http://www.tigr.org/tdb/tgi).

\section{Genetic transformation in grapevines}

Genetic transformation offers new perspectives for introducing important traits like that of disease resistance into traditional $V$. vinifera cultivars. However, the most limiting factor for efficient transformation is the absence of high-yielding regeneration protocols. The regeneration of intact transgenic plants has been obtained for viticulturally important genotypes, such as Sultana, Shiraz, Dornfelder, Chardonnay, Merlot, and others [30-35]. Due to the high morphogenetic competence of embryogenic tissue, somatic embryos are often used as targets for transformation studies. Different types of explants have been tested for their ability to produce somatic embryos under inducing conditions such as anthers [36] and leaf discs [37]. The first transformation experiments with leaf tissue of grapevine cvs. Thompson Seedless and French Colombard [38] or rootstock varieties resulted in transgenic calli, which failed to regenerate [39].

Leaf disc derived embryogenic callus for grapevine cv. Koshusanjaku by Hoshino et al. [40], who subsequently established an Agrobacterium-mediated transformation system as one of the successful methods for genetic transformation. These researchers were able to induce the calli to regenerate embryos and intact transgenic plants. This protocol was later used for callus culture development and transformation of four important Indian V. vinifera cultivars by Das et al. [41]. The successful transformation of grapevine has also been reported using the Agrobacteriummediated system by various researchers [42-44]. Genetic transformation of grapevine using direct DNA delivery via gene gun has also been reported [45].

\subsection{Genomics and transgenic research}

\subsubsection{Flavor}

In the past, various studies have been conducted on the origin and regulation of sugar and acid concentrations. Of these two processes, the regulation of acid levels 
is probably well-understood. It is clear, for example, that the two most important acids, namely, tartaric acid and malic acid, have different origins. Tartaric acid is produced directly out of the sugar pool, while malic acid is probably formed by reactions of the Krebs cycle and phosphoenolpyruvate carboxylase (PEPcase) [46]. During ripening, malic acid is used for the synthesis of sugar and as a respiration substrate [47]. Less is known about the control of tartaric acid concentration, which is also far more slowly metabolized than malic acid. Recently researchers have identified two important wine quality genes in grapevine related to tannin synthesis. By looking at when and wherein the plant tannins are produced throughout berry development and comparing similar genes in tobacco and the model plant Arabidopsis, researchers have been able to pinpoint the grape genes for tannin production. Two separate genes known as $V v A N R$ and $V v L A R 1$ are responsible for the production of chemically different types of condensed tannins also known as proanthocyanidins (PAs) in grapes [48]. The discovery of these two genes has opened ways for modifying the content and composition of anthocyanins and tannins in grapes giving vine breeders the potential to control the levels of these important wine quality characteristics $[48,49]$.

\subsubsection{Flavonoids}

In grape, flavonoids are the major portion of soluble phenolics and represent the most concentrated natural antioxidants in the berry [50]. The predominant flavonoids occurring in grape berries and seeds belong to varied classes such as tannins, anthocyanins, flavan-3-ols, and flavonols [51]. These compounds in addition to phenolic acids (mainly benzoic and hydroxycinnamic acids) contribute in different ways and/or manner to organoleptic features of the wine and other by-products [52]. Flavonoids are synthesized along the general phenylpropanoid pathway by the activity of a cytosolic multienzyme complex loosely associated at the cytoplasmic surface of the endoplasmic reticulum. This pathway has largely been characterized in different plant species [53] but also in V. vinifera in which the expression of genes involved in flavonoid synthesis (particularly anthocyanins and proanthocyanidins (PAs)) has been well-characterized in berries and seeds of both red and white cultivars [54-56]. The patterns of gene expression show significant differences between organs and cultivars, especially for genes involved in anthocyanin synthesis. In red cultivars, all the genes are expressed in berry skin although with varied temporal patterns.

In berry pulp their expression is low, and phenylalanine ammonia-lyase $(P A L)$ and UDP glucose: flavonoid 3-O-glucosyl transferase (UFGT) genes are not expressed [56]. These two genes code for enzymes involved in the first and in the last step of the anthocyanin pathway, respectively, whereas PAL allows the hydrolysis of ammonia from phenylalanine, and UFGT catalyzes the glycosylation of anthocyanidins to produce the anthocyanins (colored and stable products). The absence of UFGT has been reported in seeds [56]. On the contrary, studies concerning the expression of genes involved in flavonoid synthesis in white cultivars were performed only from berry skin. It was demonstrated that UFGT was not detectable and the expression of other associated genes was low in the skin of red cultivars especially during the early stage of berry development.

Anthocyanins are responsible for the red and white color in grapes. Grapes are primarily distinguished based on the level of anthocyanin in berry skin. Geneticists discovered that the grape skin color is controlled by two MYB genes (VvMYBA1 and $V v M Y B A 2)$. Although either can dictate the berry skin color, it was determined that mainly the $V v M Y B A 1$ gene can activate anthocyanin biosynthesis in red grapes. The $M Y B$ gene ( $V v M Y B A 2)$ allele, present in white berries, is a mutant of the latter and 
contains two distinct amino acid substitutions. Sequence analyses of the VvMYBA2 gene found 55 white grape varieties. All grape varieties contained the same double mutations, suggesting they originated from a single common grape ancestor. Vvmyb5a, a cDNA from grape cv. Cabernet Sauvignon encoding an R2R3-MYB protein, has been cloned. Phylogenetic analysis has shown that Vvmyb5a protein belongs to a different group from VlmybA2 protein. The expression of $V l m y b A$ has been detected mainly in berry skin and flesh at the late stage of berry development, whereas the expression of Vvmyb5a was detected in both vegetative and reproductive plant tissues [57].

Vvmyb5a was overexpressed in tobacco under the control of the CaMV 35S promoter for use as a visual marker, an alternative to antibiotic markers in the screening of transgenic plants [58]. The overexpression of VlmybA2 in tobacco seems to be promising for the visual identification of transformants. A versatile gene for anthocyanin production could be a good candidate for a simple and nondestructive visual marker during plant transformation $[59,60]$ and may replace controversial antibiotic marker genes. As VlmybA2 shows higher potential than other anthocyanin regulatory genes previously tested, its potential should be exploited in the genetically modified plant production process starting from the efficient recovery of transformants during transformation up to the monitoring of transgenic plants at the field level for risk assessment [61].

Until now, the models of flavonoid transport have been mainly based on genetic approaches where this process has been correlated to the expression of several specific genes in reproductive organs during development or in response to environmental factors. Limited information is available for direct identification and characterization of proteins involved in the uptake and accumulation of these metabolites. Therefore, it is crucial that future research should be more focused on the understanding of the biochemical mechanisms responsible for flavonoid transport and regulation [62].

\subsubsection{Nutraceutical value}

Muscadine (Muscadinia rotundifolia) is a native crop across the southern United States; it has natural adaptability, including resistance to diseases and insect pests, and has long vine life. Generally, it is underutilized due to its potential as a local flavor; for example, muscadines have a characteristic aroma and sweetness that makes them acceptable as table wines. In addition, it has high levels of polyphenols with potential benefits to human health. Resveratrol (3, 4, 5-trihydroxystilbene) is one of the important phenolic compounds found in muscadine grapes. Most red wines contain measurable concentrations of resveratrol; however, their concentration varies among the cultivars [63]. Resveratrol is considered a biochemical precursor of viniferin, a major stilbene phytoalexin [64]. Resveratrol is known to be synthesized by stilbene synthase (STS), a condensation enzyme with numerous biological properties in muscadines. The enzyme utilizes 4-coumaroyl-CoA (or another phenylpropanoid CoA-ester) and undergoes a three-step condensation process with malonyl-CoA, resulting in an enzyme-bound tetraketide intermediate during resveratrol synthesis.

Previous [65] study conducted at the Center for Viticulture and Small Fruit Research, Tallahassee, Florida, which involved the analysis of metabolites in local grape varieties with high-performance liquid chromatography (HPLC), determined a high phenolic content in muscadines as compared to bunch and Florida hybrid bunch grapes [65]. Grape seed extracts from some muscadine grape cultivars showed high anticancer activity. Characterization of these compounds confirmed the presence of resveratrol. One other advantage of resveratrol is its trans-isomer 
state in muscadines, which is considered the most active form. Six isoforms of the stilbene synthase gene have been isolated from the muscadine grape cv. "Regale." Out of the six isoforms, four were found to be unique to muscadine, with more than $40 \%$ sequence dissimilarity with Vitis STS. In silico analysis of one of the isoforms revealed that the deduced protein sequence has a signal peptide [66]. Further analysis using reverse transcription and quantitative real-time PCR determined that one (MS 1) of the four unique stilbene isoforms has expressed at high levels during the different stages of muscadine berry development. Further characterization of the gene encoding stilbene synthase will help determine fingerprints of muscadine cultivars with higher resveratrol content and will also help in the development of muscadine cultivars with high expression of resveratrol.

\subsubsection{Disease control}

Currently, Vitis vinifera is the major species cultivated due to its high quality for wine production. However, V. vinifera is susceptible to diseases and pests. Fungal infestation is a major problem in grapevine production worldwide. Two fungal pathogens, causing powdery and downy mildews, respectively, are a major threat in grape production. The fungal pathogens spread to Europe during the nineteenth century along with infested accessions of the American wild Vitis species in which they were endemic [67]. In general, fungal infestation leads to the decreased yield and impacts berry and wine quality through the reduction in plant vitality and productivity or by the direct infection of berries. Disease control can be achieved by the application of fungicides. However, the economic costs and negative environmental impacts associated with these applications have informed the impetus in current research for alternative strategies involving the understanding of how to manipulate host defense mechanisms. Grapevines with improved disease resistance would be welcomed, especially if other traits were not altered. The reduction of pesticide sprays by between one and two percent in a year would cut the cost of production and is also beneficial to the environment [68]. Major pathogens that infect grapevine are listed Table 2.

\begin{tabular}{llll}
\hline Causal agent & $\begin{array}{l}\text { Properties of } \\
\text { pathogen }\end{array}$ & Disease & Specific characters of disease \\
\hline $\begin{array}{l}\text { Uncinula } \\
\text { necator }\end{array}$ & $\begin{array}{l}\text { Obligate biotrophic } \\
\text { fungus }\end{array}$ & Powdery mildew & $\begin{array}{l}\text { The most economically important } \\
\text { disease of Vitis vinifera } \text { worldwide }\end{array}$ \\
\hline $\begin{array}{l}\text { Plasmopara } \\
\text { viticola }\end{array}$ & $\begin{array}{l}\text { Obligate biotrophic } \\
\text { oomycete }\end{array}$ & Downy mildew & Affects V. vinifera worldwide \\
\hline Botrytis cinerea & $\begin{array}{l}\text { Necrotrophic } \\
\text { fungus }\end{array}$ & Grey mold rot & $\begin{array}{l}\text { One of the most common and } \\
\text { widely distributed grapevine } \\
\text { diseases }\end{array}$ \\
\hline $\begin{array}{l}\text { Elsinoe } \\
\text { ampelina }\end{array}$ & $\begin{array}{l}\text { Non-obligate } \\
\text { fungus }\end{array}$ & Anthracnose & $\begin{array}{l}\text { Affects V. vinifera } \text { and its hybrids in } \\
\text { tropical and subtropical regions }\end{array}$ \\
\hline $\begin{array}{l}\text { Phomopsis } \\
\text { viticola }\end{array}$ & $\begin{array}{l}\text { Non-obligate } \\
\text { fungus }\end{array}$ & $\begin{array}{l}\text { Phomopsis cane } \\
\text { blight and leaf spot }\end{array}$ & A wood disease \\
\hline $\begin{array}{l}\text { Fusicoccum } \\
\text { aesculi }\end{array}$ & $\begin{array}{l}\text { Non-obligate } \\
\text { fungus }\end{array}$ & Excoriosis & A wood disease \\
\hline & Ascomycete fungus & Eutypa dieback & $\begin{array}{l}\text { A major grapevine disease in many } \\
\text { countries that infects the vine stock; } \\
\text { a wood disease }\end{array}$ \\
\hline
\end{tabular}

Table 2.

The major widespread and economically important pathogens affecting grapevines worldwide [69]. 
Knowledge and experience in the field of genetically engineered grapevines have increased enormously. Several ongoing projects are aimed at the improvement of transformation efficiency, allowing its use as a standard strategy for various purposes. The great interest in the transgenic approach is due to its capability to establish disease tolerance or resistance in both elite grapevine varieties and rootstocks without changing their genotype-specific traits. Progress made in grapevine genomics along with the availability of reference genome sequence obtained from Pinot Noir [70] has made the transgenic approach attractive for both basic research and functional genomics. Included herein is a list of major transgenic diseasetolerant plants, which are currently in field trials in the last 5 years for improved bacterial and fungal resistance (Table 3).

\begin{tabular}{|c|c|c|c|c|c|c|}
\hline Institution & Received & Status & Gene(s) & Phenotype(s) & $\begin{array}{l}\text { Release } \\
\text { location }\end{array}$ & Acreage \\
\hline $\begin{array}{l}\text { Cornell } \\
\text { University }\end{array}$ & 07/21/09 & Issued & $\begin{array}{l}\text { Coat protein- } \\
\text { donor: Grapevine } \\
\text { fan leaf virus } \\
\text { resistant }\end{array}$ & $\begin{array}{c}\text { Grapevine Fan } \\
\text { leaf Nepovirus } \\
\text { Resistant }\end{array}$ & $\begin{array}{l}\text { CA, } \\
\text { USA }\end{array}$ & 4 \\
\hline $\begin{array}{l}\text { University } \\
\text { of Florida }\end{array}$ & 09/27/07 & Acknowledged & $\begin{array}{c}\text { Aequorea } \\
\text { victoria/E. coli } \\
\text { lytic peptide } \\
\text { gene for bacterial } \\
\text { resistance }\end{array}$ & $\begin{array}{c}\text { Xylella } \\
\text { fastidiosa } \\
\text { Resistant }\end{array}$ & FL, USA & 1.1 \\
\hline $\begin{array}{l}\text { University } \\
\text { of Florida }\end{array}$ & 09/27/07 & Acknowledged & $\begin{array}{l}\text { Lytic peptide } \\
\text { gene for bacterial } \\
\text { resistance } E \text {. coli } \\
\text { Endogenous } \\
\text { gene for fungal } \\
\text { resistance }\end{array}$ & $\begin{array}{l}\text { Powdery } \\
\text { Mildew } \\
\text { Resistant } \\
\text { BR-X. } \\
\text { fastidiosa } \\
\text { Resistant }\end{array}$ & FL, USA & 1.1 \\
\hline $\begin{array}{l}\text { University } \\
\text { of Florida }\end{array}$ & 09/27/07 & Acknowledged & $\begin{array}{l}\text { Endogenous } \\
\text { gene for fungal } \\
\text { resistance-grape } \\
\text { lytic peptide } \\
\text { gene for bacterial } \\
\text { resistance }\end{array}$ & $\begin{array}{l}\text { Powdery } \\
\text { Mildew } \\
\text { Resistant } \\
\text { BR-X. } \\
\text { fastidiosa } \\
\text { Resistant }\end{array}$ & FL, USA & 1.1 \\
\hline $\begin{array}{l}\text { University } \\
\text { of Florida }\end{array}$ & 09/27/07 & Acknowledged & $\begin{array}{l}\text { Lytic peptide } \\
\text { gene for bacterial } \\
\text { resistance }\end{array}$ & $\begin{array}{c}\text { X. fastidiosa } \\
\text { Resistant }\end{array}$ & FL, USA & 1.1 \\
\hline $\begin{array}{l}\text { University } \\
\text { of Florida }\end{array}$ & 09/27/07 & Acknowledged & $\begin{array}{l}\text { Lytic peptide } \\
\text { gene for bacterial } \\
\text { resistance }\end{array}$ & $\begin{array}{c}X . \text { fastidiosa } \\
\text { Resistant }\end{array}$ & FL, USA & 1.1 \\
\hline $\begin{array}{l}\text { University } \\
\text { of Florida }\end{array}$ & 09/13/06 & Acknowledged & $\begin{array}{l}\text { Synthetic lytic } \\
\text { peptide gene } \\
\text { Grape thaumatin- } \\
\text { like protein gene }\end{array}$ & $\begin{array}{l}\text { Fungal } \\
\text { Resistant, } \\
\text { Bacteria } \\
\text { Resistant }\end{array}$ & FL, USA & \\
\hline $\begin{array}{l}\text { University } \\
\text { of Florida }\end{array}$ & 09/13/06 & Acknowledged & $\begin{array}{c}\text { Neomycin } \\
\text { phosphotransferase } \\
\text { (NPTII) }^{*} \text { Synthetic } \\
\text { lytic peptide } \\
\text { gene cercopin of } \\
\text { Silkworm } \\
\text { Grape thaumatin- } \\
\text { like protein gene }\end{array}$ & $\begin{array}{c}\text { Fungal } \\
\text { Resistant, } \\
\text { FR-Fungal } \\
\text { Resistant, } \\
\text {-Bacteria } \\
\text { Resistant }\end{array}$ & FL, USA & \\
\hline
\end{tabular}




\begin{tabular}{|c|c|c|c|c|c|c|}
\hline Institution & Received & Status & Gene(s) & Phenotype(s) & $\begin{array}{l}\text { Release } \\
\text { location }\end{array}$ & Acreage \\
\hline $\begin{array}{l}\text { University } \\
\text { of Florida }\end{array}$ & 09/13/06 & Acknowledged & $\begin{array}{l}\text { Synthetic lytic } \\
\text { peptide gene } \\
\text { cercopin of } \\
\text { Silkworm } \\
\text { Grape thaumatin- } \\
\text { like protein gene }\end{array}$ & $\begin{array}{l}\text { Bacteria } \\
\text { Resistant, } \\
\text { Fungal } \\
\text { Resistant }\end{array}$ & FL, USA & \\
\hline $\begin{array}{l}\text { State } \\
\text { University } \\
\text { of New York }\end{array}$ & $08 / 02 / 06$ & Acknowledged & $\begin{array}{l}\text { Lignan biosynthesis } \\
\text { protein from peas }\end{array}$ & $\begin{array}{l}\text { Powdery } \\
\text { Mildew } \\
\text { Resistant }\end{array}$ & NY, USA & 1 \\
\hline $\begin{array}{l}\text { Cornell } \\
\text { University }\end{array}$ & $03 / 03 / 06$ & Acknowledged & $\begin{array}{l}\text { Antimicrobial } \\
\text { peptide from } \\
\text { Amaranthus } \\
\text { caudatus } \\
\text { Magainin from } \\
\text { Xanopus laevis } \\
\text { NptII }^{*}\end{array}$ & $\begin{array}{l}\text { Pathogen } \\
\text { resistant }\end{array}$ & TX, USA & 0.1 \\
\hline $\begin{array}{l}\text { State } \\
\text { University } \\
\text { of New York }\end{array}$ & 04/11/05 & Acknowledged & $\begin{array}{l}\text { Lignan biosynthesis } \\
\text { protein }\end{array}$ & $\begin{array}{l}\text { Powdery } \\
\text { Mildew } \\
\text { Resistant }\end{array}$ & NY, USA & 1 \\
\hline
\end{tabular}

Table 3 .

Transgenic grape plants in field trails resistance to major pathogens.

\subsubsection{Downy mildew}

Different strategies and genes have been used in genetic engineering to enhance resistance to major plant pathogens [71]. Expression of a fungal endochitinase gene in cv. "Chardonnay" led to reduced symptoms of powdery mildew and Botrytis bunch rot [72]. Another strategy, in this regard, involves the use of antimicrobial peptides (AMPs). These are natural defense compounds found in many organisms ranging from bacteria to humans and plants, which protect the host from pathogens. Among these compounds include magainins [73] isolated from the skin of an African clawed frog, Xenopus laevis. Magainins and their analogs are small (c.a. 21-26 amino acids long) cationic peptides with $\alpha$-helical structure with broad-spectrum antimicrobial activity, which was demonstrated in vitro and led to the inhibition of growth of bacteria and fungi [74, 75], including major grapevine pathogens such as A. tumefaciens [76]. Magainins have a strong affinity for microbial membranes due to the high concentration of anionic phospholipids in the outer bilayer of their leaflet. They confer very low toxicity to animal and plant cells due to the presence of cholesterol or other sterols in the host membranes [74]. Magainins can disturb cell membrane function either by forming ion channels or by depolarizing the membrane leading to leakage of metabolites and cell death [77]. The selective activity of magainins and their synthetic derivatives on microbial membranes as well as their simple amino acid sequence enables them to be potential candidates for genetic engineering for disease-resistant plants [78]. Recently, transgenic plants with expressed high levels of magainin peptides exhibited significant resistance to a broad range of fungi and bacteria, including pathogens causing botrytis and powdery mildew diseases [79].

The expression of synthetic magainins, such as Myp30 [80] and MSI99 in transgenic plants via either the chloroplast genome [81] or in the nuclear genome [82], led to enhanced resistance against bacterial and fungal pathogens. The studies 
in "Chardonnay" ( V. vinifera) have shown stable transformation and expression of either the natural magainin-2 (mag2) or the synthetic derivative (MSI99) gene under the control of Arabidopsis ubiquitin-3 promoter. Some transgenic lines exhibited enhanced resistance to crown gall and powdery mildew diseases in the greenhouse. Data suggested that the expression of magainin-type genes can confer resistance to the bacterial disease, crown gall, and moderate symptom reduction in the fungal disease, caused by powdery mildew pathogen.

\subsubsection{Pierce’s disease}

The most devastating diseases in the southeastern United States include Pierce's disease commonly present on bunch grapes and anthracnose that infects Florida hybrid bunch grapes (Figure 1) [83]. Pierce's disease, caused by the bacterium Xylella fastidiosa, is a serious bacterial disease of grapevines. It is spread by certain types of xylem feeding leafhoppers (Cicadellidae) known as sharpshooters. The bacterium is an obligate pathogen that lives in the xylem tissue of a wide variety of plants. The bacteria, $X$. fastidiosa, are limited to the xylem or water-conducting vessels of plants. Symptoms begin to develop about midsummer as the bacteria block these vessels leading to dry or scorched leaves. Leaves become chlorotic along the outer edges or adjacent to the dead tissue. The drying or scorching of the leaf continues for a few days to weeks until the leaf eventually falls off, leaving only the petiole attached to the cane. Petioles gradually die back and fall. Maturing canes are tan in color with green islands along the infected sections. When new vegetative growths occur on infected canes, they are delayed and are usually stunted. Leaves on stunted shoots have a yellow mottling color between the major veins. Depending on the grape variety, death of the entire vine usually occurs in 1-5 years.

A study was conducted at the Center for Viticulture and Small Fruit Research, Tallahassee, Florida, USA, to understand the molecular basis of Pierce's disease tolerance by employing subtractive hybridization $(\mathrm{SH})$ and real-time PCR for the detection and characterization of transcripts, which are differentially expressed in the xylem tissue challenged by PD bacterium. Results obtained from the SH analysis of 300 partial cDNAs indicated high to moderate expression patterns in PD-tolerant $c v$. "Blanc du Bois" (Florida hybrid) and "Zinfandel" (bunch grape) subtracted with PD-susceptible bunch cv. "Pinot Noir." The expression patterns of selected genes and their potential association with PD tolerance were analyzed using real-time PCR. Research showed that enolase expression, an enzyme that has been associated with bacterial activity, was high in PD-susceptible cultivar. The PD-susceptible

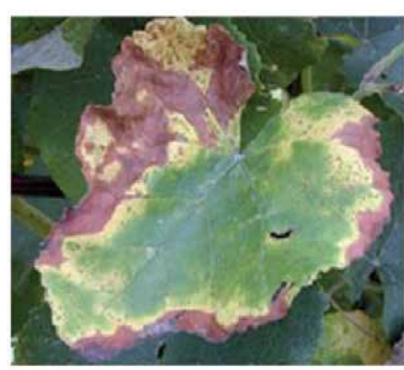

Pierce's Disease

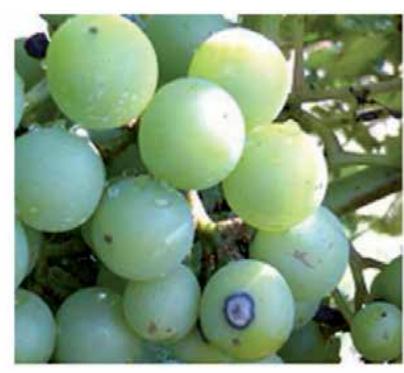

Anthracnose

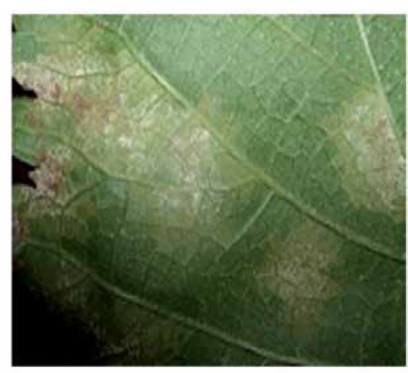

Downy Mildew

Figure 1.

Common diseases of grapes. Note: The picture of a downy mildew infection is from Ya Li Zhang, China Agricultural University, Beijing, China. 
cultivar was severely infected by $X$. fastidiosa. The expression of defense-related enzymes, such as chalcone synthase, s-adenosyl-L-methionine synthase, chitinase, PR genes, adenosine kinase, quinine reductase, and translationally controlled tumor protein, was observed in PD-tolerant grape cultivars. Also, PD-tolerant cultivars showed high expression of protease inhibitor and stilbene synthase mRNA, which suggested that the presence of $X$. fastidiosa had influenced the expression levels of transcripts associated with signal transduction and host defense more significantly in PD-susceptible cultivars than in PD-tolerant cultivars. Early expression of these genes in PD-tolerant cultivars postinfection with $X$. fastidiosa may have modulated tolerance in the grape cultivars.

Transgenic Pierce's disease-resistant plants have been developed using polygalacturonase-inhibiting proteins (PGIPs) and antimicrobial peptides. PGIPs are plant cell wall proteins that specifically inhibit fungal endo-polygalacturonases (PGs) that contribute to an aggressive decomposition of susceptible plant tissues. The inhibition of fungal PGs by PGIPs suggested that PGIPs have a role in plant tolerance to fungal infections, and this has been confirmed in transgenic plants expressing PGIPs. The bacterium, $X$. fastidiosa, the causal agent of Pierce's disease (PD) in grapevines, contains genes encoding cell wall-degrading enzymes, including a putative PG enzyme. Research hypothesis suggested that PGIP expression can confer tolerance against both $X$. fastidiosa and Botrytis cinerea. This hypothesis was tested by transforming cvs. "Thompson Seedless" and "Chardonnay" with $V$. vinifera. The transformants had a pear fruit PGIP-encoding gene $(p P G I P)$ under the control of the CaMV 35S promoter. Results determined substantial pear PGIP ( $p P G I P$ ) activity in crude extracts of grape leaves and xylem exudates of transgenic lines obtained from independent transformation events but were not present in untransformed controls. Also, $p P G I P$ activity was detected in the xylem exudate of untransformed scions grafted on to transgenic rootstocks expressing $p$ PGIP [84].

AMPs are particularly effective against bacteria since they disrupt cell membranes. To date, transgenic plants with antimicrobial peptides have been generated. The plants included 76 "Chardonnay" lines and transformed with two magainin-type genes, mag2 and MSI99, as well as a PGL class gene. The primary objective of the research was to study the potential resistance to Pierce's disease of magainin- and PGL-producing vines. A newly designed antimicrobial peptide was developed based on natural antibacterial toxins. For example, shiva-1 peptide was designed with a significantly different sequence from natural cecropin B (46\% homology) [85, 86]. A more advanced generation of lytic peptides was based on the synthesis of newly designed antimicrobial peptides instead of its natural antibacterial toxin [86]. The design of synthetic antimicrobial peptides with predetermined structures and properties led to improved stability of these gene products and enhanced their protection property against proteases in the transformed plants.

In another research with the objective to control Pierce's disease, Aguero et al. [87] studied transgenic plants of grape cvs. "Chardonnay" and "Thompson Seedless" by expressing the pear polygalacturonase protein (pGIP). They reported a delayed development of Pierce's disease in some of the transgenic lines. The lines had reduced leaf scorching, lower titers of $X$. fastidiosa, and better regrowth after pruning than untransformed control lines. Two US patents have been granted to Scorza and Gray $[88,89]$ for the method of production of transgenic grapevine cv. "Thompson Seedless" and expression of the lytic peptide cecropin B and shiva-1 peptides that improved resistance to the bacterium $X$. fastidiosa. The authors suggested that the expression of magainin-type antimicrobial peptides in grapevines was likely more effective toward the control of bacteria than fungi. 


\subsubsection{Anthracnose}

Genetic resources possessing genes for resistance to many fungal diseases have been found in Vitis species, and therefore, the transfer of these genes to susceptible $V$. vinifera cultivars has been successfully carried out to a certain extent [12]. However, the process can take several years, and it is rather difficult to breed disease-resistant grapevines with the commercial value from such interspecific hybrids. It has been revealed that plants have innate defense mechanisms that involve pathogen-related proteins, e.g., chitinase [90, 91] and $\beta-1,3$-glucanase [92], to control pathogen infection. Genes encoding hydrolytic enzymes, such as chitinase, which can degrade fungal cell wall components are potential candidates for the improvement of disease resistance. The rice chitinase $R C C 2$ gene could be utilized as a genetic source for disease resistance, leading to breeding and improvement of resistance in grape species. Transgenic grapevines with the $R C C 2$ gene were tested for resistance to the fungus, Elsinoe ampelina, which causes anthracnose disease. Fungal conidiophores were unable to germinate at the initial phase of infection, but transgenic plants exhibited severe symptoms during the later stages of incubation [93]. Conversely, rice chitinase $R C C 2$ was unable to confer resistance to anthracnose disease.

Recently, researchers at the Center for Viticulture and Small Fruit Research, Tallahassee, Florida, USA, successfully identified genes/gene products from Florida hybrid grape that are uniquely expressed in response to anthracnose infestation postinoculation with pure cultures of E. ampelina isolated from field-grown grape plant cv. "Blanc du Bois.” Differential display RT-PCR analysis identified several unique genes induced upon Elsinoe infection in anthracnose-tolerant hybrid bunch grape. Sequencing and characterization of these genes revealed their similarity with chitinase III, PR 4 and 10, chalcone synthase, and stilbene synthase. Further, realtime PCR analysis revealed that the expression patterns of gene-encoding enzymes, such as chitinase and stilbene synthase, were higher than that of other genes during E. ampelina infestation [94]. These genes are known to play an important role in plant defense against fungal pathogens. Expression of these genes was rapid in anthracnose-tolerant Florida hybrid bunch grape cultivars upon Elsinoe infection as compared to anthracnose-susceptible cultivars. Chitinase gene (antifungal) expression was completely absent in susceptible cultivars upon Elsinoe infection but showed a low-level expression level of the stilbene synthase gene. In contrast, the tolerant cultivars appeared to have maintained the expression of these defenserelated genes in order to overcome the adverse effects of infection. Further study of these uniquely expressed genes should inform the understanding of the basis of their specific role in anthracnose tolerance. A great deal of effort over the past several years has been made to understand the plant-pathogen interaction. This has provided an excellent framework for the identification of over 100 genes associated with disease resistance which has been incorporated in numerous ongoing transgenic research initiatives.

\section{Conclusion}

The grape industry must maintain and expand grape production despite increasing constraints caused by pests, diseases, and abiotic stressors. Biotechnology represents one of the most promising approaches that can bridge the knowledge gap that exists since it is crucial for the introduction of single gene determinants with defined phenotypic traits. In addition to aiding the production of grapevine varieties (disease-resistant and stress-tolerant), biotechnology has also contributed to the 
modification of numerous quality traits, such as color, flavor, ripening characteristics, and modulation of specific metabolites with potential health benefits. Multiple genes for disease resistance and/or modification of quality traits should be inserted simultaneously into grape cultivars. However, researchers are still concerned that the product of a single gene could readily be overcome by virulent pathogens. New genes are being sought from grapevines and other close relatives with an attempt to create a comprehensive genetic gene pool for the improvement of grapevines. Genetically altered vines should be subjected to stringent field testing to assure the public that ultimately the technology will be safe and will not alter essential traits of both the vine and the fruit. These advantages can only be realized if concrete strategies are put in place to overcome potential technical hurdles. Strategies should be put in place that involve a comprehensive regulatory framework to improve the general public acceptance of such biotechnology-derived foods.

\section{Acknowledgements}

The corresponding author Kambiranda D would like to acknowledge the funds received from USDA-Evans-Allen project 621660.

\section{Author details}

Devaiah Kambiranda*, James Obuya and Janana Snowden

Plant and Soil Science, Southern University Agriculture Research and Extension

Center, Baton Rouge, LA, USA

*Address all correspondence to: devaiah.kambiranda@gmail.com

IntechOpen

(C) 2020 The Author(s). Licensee IntechOpen. This chapter is distributed under the terms of the Creative Commons Attribution License (http://creativecommons.org/licenses/ by/3.0), which permits unrestricted use, distribution, and reproduction in any medium, provided the original work is properly cited. (cc) BY 


\section{References}

[1] Anonymus. FAOSTAT Database. 2017. Available from: http://faostat.fao.org

[2] Anonymus. Wine Institute. 2015. Available from: http://www. wineinstitute.org

[3] Thomas MR, Matsumoto S, Cain P, Scott NS. Repetitive DNA of grapevine: Classes present and sequences suitable for cultivar identification. Theoretical and Applied Genetics. 1993;86:173-180

[4] Barticevic M, Zavala K, De Felice S, et al. Phenotypic characterization of microsatellite-fingerprinted segregants, focused on seedlessness and gibberellic acid response on berry size of grapes. Agricultura Técnica. 2004;64:3-16

[5] Lodhi MA, Reisch BI. Nuclear DNA content of Vitis species, cultivars, and other genera of the Vitaceae. Theoretical and Applied Genetics. 1995;90:11-16

[6] Hewstone N, Valenzuela J, Muñoz C. Cultivar effect in the development of stenospermocarpic grape embryos cultured in vitro. Agricultura Técnica. 2006;66:124-132

[7] Wei X, Sykes SR, Clingeleffer PR. An investigation to estimate genetic parameters in CSIRO's table grape breeding program. 2 . Quality characteristics. Euphytica. 2002;128:343-351

[8] Ejsmentewicz T, Balic I, Sanhueza D, Barria R, et al. Comparative study of two table grape varieties with contrasting texture during cold storage. Molecules (Basel, Switzerland). 2015;20(3):3667-3680

[9] De Lattin G. On the genetics of grapes. Present results of factor analysis in the genus Vitis. Vitis. 1957;1:1-8

[10] Reisch BI, Pratt C. Grapes. In: Janick J, Moore JN, editors. Fruit
Breeding. Volume II: Vine and Small Fruits. New York: John Wiley \& Sons, Inc; 1996. pp. 197-369

[11] Paterson AH, editor. Genome Mapping in Plants. San Diego, CA: Academic Press; 1996. pp. 193-210

[12] Alleweldt G, Roy SP, Reisch B. Grapes (Vitis). In: Moore JN, Ballington JR, editors. Genetic Resources of Temperate Fruit and Nut Crops I. Wageningen: International Society for Horticultural Science; 1990. pp. 291-327

[13] Staub JE, Serquen FC, Gupta M. Genetic markers, map construction, and their application in plant breeding. HortScience. 1996;31:729-741

[14] Chen J, Lamikanra O, Chang CJ, Hopkins DL. Randomly amplified polymorphic DNA analysis of Xylella fastidiosa: Pierce's disease and oak leaf scorch pathotypes. Applied and Environmental Microbiology. 1995;61:1688-1690

[15] Wyman AR, White R. A highly polymorphic locus in human DNA. Proceedings of the National Academy of Sciences of the United States of America. 1980;77:6754-6756

[16] Couto MMB, Vogels JTWE, Hofstra JH, et al. Random amplified polymorphic DNA and restriction enzyme analysis of PCR amplified rDNA in taxonomy: Two identification techniques for food-borne yeasts. The Journal of Applied Bacteriology. 1995;79:525-535

[17] Tessier C, David J, This P, et al. Optimization of the choice of molecular markers for varietal identification in Vitis vinifera $\mathrm{L}$. Theoretical and Applied Genetics. 1999;98:171-177

[18] Collins GG, Symons RH. Polymorphisms in grapevine DNA 
detected by the RAPD PCR technique. Plant Molecular Biology Reporter. 1993;11:105-112

[19] Jaques JI, Defontaine A, Hallet JN. Characterization of Vitis vinifera cultivars by random amplified polymorphic DNA markers. Vitis. 1993;32:189-190

[20] Tschammer J, Zyprian E. Molecular characterization of grapevine cultivars of Riesling-type and of closely related Burgundies. Vitis. 1994;33:249-250

[21] Gogorcena Y, Arulsekar S, Dandekar AM, Parfitt DE. Molecular markers for grape characterization. Vitis. 1993;32:183-185

\section{[22] Botta R, Scott NS, Eynard I,} Thomas MR. Evaluation of microsatellite sequence tagged site markers for characterizing Vitis vinifera cultivars. Vitis. 1995;34:99-102

[23] Loureiro MD, Martinez MC, Boursiquot JM, This P. Molecular marker analysis of Vitis vinifera "Albarino" and some similar grapevine cultivars. Journal of the American Society for Horticultural Science. 1998;123:842-848

[24] Regner F, Sefc K, Stadlbauer A, Steinkellner H. Genetic markers for the identification of varieties and clones as a guarantee of quality. Acta Horticulturae. 1998;473:49-61

[25] Moreno S, Gogorcena Y, Ortiz JM. The use of RAPD markers for identification of cultivated grapevine (Vitis vinifera L.). Scientia Horticulturae. 1995;62:237-243

[26] Thomas MR, Scott NS. Microsatellite sequence tagged site markers: Simplified technique for rapidly obtaining flanking sequences. Plant Molecular Biology. 1994;12:58-64

[27] Sefc KM, Pejic I, Maletić E, et al. Micr0satelite markers for grapevine:
Tools for cultivar identification and pedigree reconstruction. In: Roubelakis-Angelakis KA, editor. Grapevine Molecular Physiology and Biotechnology. 2nd ed. Dordrecht. The Netherlands: Springer; 2009. pp. 565-596

[28] Cipriani G, Marrazzo MT, Gaspero GD, et al. Set of microsatellite markers with long core repeat optimized for grape (Vitis spp.) genotyping. BMC Plant Biology [Serial on the Internet]. 2008. Available from: http://www. biomedcentral.com/1471-2229/8/127

[29] Salmaso M, Faes G, Segala C, et al. Genome diversity and gene haplotypes in the grapevine (Vitis vinifera L.), as revealed by single nucleotide polymorphisms. Molecular Breeding. 2004;14:385-395

[30] Walsh PS, Erlich HA, Higuchi R. Preferential PCR amplification of alleles: Mechanisms and solutions. Genome Research. 1992;1:241-250

[31] Wang Q, Li P, Hanania U, et al. Improvement of Agrobacteriummediated transformation efficiency and transgenic plant regeneration of Vitis vinifera $\mathrm{L}$. by optimizing selection regimes and utilizing cryopreserved cell suspensions. Plant Science. 2005;168:565-571

[32] Harst M, Bornhoff BA, Zyprian E, et al. Regeneration and transformation of different explants of Vitis vinifera spp. Acta Horticulturae. 2000;528:289-295

[33] Kikkert JK, Ali GS, Wallace PG, et al. Expression of fungal chitinase in Vitis vinifera L. 'Merlot' and 'Chardonnay' plants produced by biolistic information. Acta Horticulturae. 2000;528:297-303

[34] Thomas MR, Iocco P, Franks T. Transgenic grapevines: Status and future. Acta Horticulturae. 2000;528:279-287 
[35] Vidal JR, Kikkert JK, Wallace PG, Reisch B. High efficiency biolistic co-transformation and regeneration of 'Chardonnay (Vitis vinifera L.) containing npt-II and antimicrobial peptide genes. Plant Cell Reports. 2003;22:252-260

[36] Iocco P, Franks T, Thomas MR. Genetic transformation of major vine grape cultivars of Vitis vinifera L. Transgenic Research. 2001;10:105-112

[37] Franks T, He DG, Thomas MR. Regeneration of transgenic Vitis vinifera L. Sultana plants: Genotypic and phenotypic analysis. Molecular Breeding. 1998;4:321-333

[38] Colby SM, Juncosa AM, Meredith CP. Cellular differences in Agrobacterium susceptibility and regenerate capacity restrict the development of transgenic grapevines. Journal of the American Society for Horticultural Science. 1991;166:356-361

[39] Berres R, Otten L, Tinland B, et al. Transformation of Vitis tissue by different strains of Agrobacterium tumefaciens containing T-6b gene. Plant Cell Reports. 1992;11:192-195

[40] Hoshino Y, Zhu YM, Nakano M, et al. Production of transgenic grapevine (Vitis vinifera L. cv. Koshusanjaku) plants by co-cultivation of embryogenic calli with Agrobacterium tumefaciens and selecting secondary embryos. Plant Biotechnology. 1998;15:29-33

[41] Das D, Reddy M, Upadhyaya S, Sopory S. An efficient leaf disc culture method for the regeneration via somatic embryogenesis and transformation of grape (Vitis vinifera L.). Plant Cell Reports. 2002;20:999-1005

[42] Iocco P, Franks T, Thomas MR. Genetic transformation of major vine grape cultivars of Vitis vinifera L. Transgenic Research. 2001;10:105-112
[43] Harst M, Bornhoff BA, Zyprian E, Jach G, Topfer R. Regeneration and Transformation of different explants of Vitis vinifera spp. Acta Horticulturae. 2000;528:289-295

[44] Torregrosa L, Iocco P, Thomas MR. Influence of Agrobacterium strain, culture medium and cultivar on the transformation efficiency of Vitis vinifera L. American Journal of Enology and Viticulture. 2002;53:183-190

[45] Kikkert JK, Ali GS, Wallace PG, Reustle GM, Reisch B. Expression of fungal chitinase in Vitis vinifera $\mathrm{L}$. 'Merlot' and 'Chardonnay' plants produced by biolistic information. Acta Horticulturae. 2000;528:297-303

[46] Ruffner HP. Metabolism of tartaric and malic acids in Vitis: A reviewPart A. Vitis. 1982;21:247-259

[47] Hunter JJ, Skrivan R, Ruffner HP. Diurnal and seasonal physiological changes in Vitis vinifera: $\mathrm{CO}_{2}$ assimilation rates, sugar levels and sucrolytic activity. Vitis. 1994;33:189-195

[48] Bogs J, Downey MO, Harvey JS, et al. Proanthocyanidin synthesis and expression of genes encoding leucoanthocyanidin reductase and anthocyanidin reductase in developing grape berries and grapevine leaves. Plant Physiology. 2005;139:652-663

[49] Kanellis AK, Roubelakis-Angelakis KA. In: Seymour G, Taylor J, Tucker G, editors. Biochemistry of Fruit Ripening. London: Chapman and Hall; 1993.

pp. $189-234$

[50] Conde C, Silva P, Fontes N, et al. Biochemical changes throughout grape berry development and fruit and wine quality. Food. 2007;1:1-22

[51] Adams DO. Phenolics and ripening in grape berries. American Journal of Enology and Viticulture. 2006;57:249-256 
[52] Pinelo M, Arnous A, Meyer AS. Upgrading of grape skins: Significance of plant cell-wall structural components and extraction techniques for phenol release. Trends in Food Science and Technology. 2006;17:579-590

[53] Winkel SB. In: Grotewold E, editor. Science of Flavonoids. Berlin: Springer Verlag; 2006. pp. 71-95

[54] Bogs J, Downey MO, Harvey JS, Ashton AR, Tanner GJ, Robinson SP. Proanthocyanidin synthesis and expression of genes encoding leucoanthocyanidin reductase and anthocyanidin reductase in developing grape berries and grapevine leaves. Plant Physiology. 2005;139:652-663

[55] Castellarin SD, Pfeiffer A, Sivilotti P, et al. Transcriptional regulation of anthocyanin biosynthesis in ripening fruits of grapevine under seasonal water deficit. Plant, Cell \& Environment. 2007;30:1381-1399

[56] Boss PK, Davies C, Robinson SP. Analysis of the expression of anthocyanin pathway genes in developing Vitis vinifera L. cv Shiraz grape berries and the implications for pathway regulation. Plant Physiology. 1996;111:1059-1066

[57] Boss PK, Davies C, Robinson SP. Expression of anthocyanin biosynthesis pathway genes in red and white grapes. Plant Molecular Biology. 1996;32:565-579

[58] Deluc L, Barrieu F, Marchive C, et al. Characterization of grapevine R2R3-MYB transcription factor that regulates the phenylpropanoid pathway. Plant Physiology. 2006;140:499-411

[59] Goldsbrough AP, Tong Y, Yoder JI. Lc as a nondestructive visual reporter and transposition excision marker gene for tomato. The Plant Journal. 1996;9:927-933
[60] Ludwig SR, Bowen B, Beach L, Wessler SR. A regulatory gene as a novel visible marker for maize transformation. Science. 1990;247:449-450

[61] Tamaoki M, Imai H, Takahashi H, et al. Development of visible markers for transgenic plants and their availability for environmental risk assessment. Zeitschrift für Naturforschung. 2006;61:377-386

[62] Braidot E, Zancani M, Petrussa E, et al. Transport and accumulation of flavonoids in grapevine (Vitis vinifera L.). Plant Signaling \& Behavior. 2008;3:626-632

[63] Siemann E, Creasy L. Concentration of the phytoalexin resveratrol in wine.

American Journal of Enology and Viticulture. 1992;43:49-52

[64] Sotheeswaran S, Pasupathy V. Distribution of resveratrol oligomers in plants. Photochemistry. 1993;22:1083-1093

[65] Basha SM, Musingo M, Colova VS. Compositional differences in the phenolics compounds of muscadine and bunch grape wines. African Journal of Biotechnology. 2004;10:523-528

[66] Vasanthaiah HKN, Katam R, Basha SM. A new stilbene synthase gene from muscadine (Vitis rotundifolia) grape berry. In: IEEE Proceeding of FBIT; 2007: Jeju Island, Korea. 2007. pp. $87-91$

[67] Jaillon O, Aury JM, Noel B, et al. The grapevine genome sequence suggests ancestral exploration in major angiosperm phyla. Nature. 2007;449:463-467

[68] Galet P. The diseases and parasites of the grapevine. In: Galet P, editor. Imprimerie du Paysan du Midi. Montpellier, France; 1977. p. 871 
[69] Ferreira RB, Monteiro SS, Piçarra-Pereira MA, Teixeira AR. Engineering grapevine for increased resistance to fungal pathogens without compromising wine stability. Trends in Biotechnology. 2004;22:168-173

[70] Velasco R, Zharkikh A, Troggio M, et al. A high quality draft consensus sequence of the genome of a heterozygous grapevine variety. PLOS One [Serial on the Internet]. 2007. Available from: http://www.plosone. org/article/info:doi/10.1371/journal. pone. 0001326

[71] Punja ZK. Genetic engineering of plants to enhance resistance to fungal pathogens. A review of progress and future prospects. Canadian Journal of Plant Pathology. 2001;23:216-235

[72] Reisch BI, Kikkert JR, Vidal JR, et al. Genetic transformation of Vitis vinifera to improve disease resistance. Acta Horticulturae. 2003;603:303-308

[73] Zasloff M. Antimicrobial peptides of multicellular organisms. Nature. 2002;415:389-395

[74] Kristyanne ES, Kim KS, Stewart JMD. Magainin 2 effects on the ultrastructure of five plant pathogens. Mycologia. 1997;89:353-360

[75] Alan AR, Earle ED. Sensitivity of bacterial and fungal plant pathogens to the lytic peptides, MSI99, magainin II, and cecropin B. Molecular PlantMicrobe Interactions. 2002;15:701-708

[76] Li ZT, Gray DJ. Effect of five antimicrobial peptides on the growth of A. tumefaciens, E. coli and Xylella fastidiosa. Vitis. 2003;42:95-97

[77] Bechinger B. Structure and functions of channel-forming peptides: Magainins, cecropins, melittin and alamethicin. The Journal of Membrane Biology. 1997;156:197-211
[78] Powell WA, Catranis CM, Maynard CA. Synthetic antimicrobial peptide design. Molecular PlantMicrobe Interactions. 1995;8:792-794

[79] Smith F, Blowers AD, Van Eck J, Sanford J. Expression of magainin and PGL classes of antimicrobial peptide genes in plants and their use in creating resistance to multiple plant pathogens. US 6235973 B1; 2001

[80] Li Q, Lawrence CB, Xing HY, et al. Enhanced disease resistance conferred by expression of an antimicrobial magainin analog in transgenic tobacco. Planta. 2001;212:635-639

[81] De Gray G, Rajasekaran K, Smith F, et al. Expression of an antimicrobial peptide via the chloroplast genome to control phytopathogenic bacteria and fungi. Plant Physiology. 2001;127:852-862

[82] Chakrabarti A, Ganapathi TR, Mukherjee PK, Bapat VA. MSI-99, a magainin analogue, imparts enhanced disease resistance in transgenic tobacco and banana. Planta. 2003;216:587-596

[83] Vasanthaiah HKN, Basha SM. Why molecular approach to develop disease tolerant grapes. In: Grape Times. 2008. p. 5

[84] Agüero C, Uratsu S, Greve C, et al. Evaluation of tolerance to Pierce's disease and Botrytis in transgenic plants of Vitis vinifera L expressing the pear PGIP gene. Molecular Plant Pathology. 2005;6:43-51

[85] Fink J, Boman A, Boman HG, Merrifield RB. Design, synthesis and antibacterial activity of cecropinilike model peptides. International Journal of Peptide and Protein Research. 1989;33:412-421

[86] Destefano BL, Nagpala PG, Cetiner SM, et al. In: Chet I, editor. 
Biotechnology in Plant Disease Control. New York: John Wiley \& Sons; 1993

[87] Aguero C, Uratsu S, Greve C, Powell A, Labavitch J, Meredith C, et al. Evaluation of tolerance to Pierce's disease and Botrytis in transgenic plants of Vitis vinifera L expressing the pear PGIP gene. Molecular Plant Pathology. 2005;6:43-51

[88] Scorza R, Gray DJ. Disease resistance in Vitis. US 6232528 B1; 2001

[89] Scorza R, Gray DJ. Disease resistance in Vitis. US 7151203 B2; 2006

[90] Legrand M, Kauffmann S, Geoffroy P, Fritig B. Biological function of pathogenesis-related proteins: Four tobacco pathogenesis-related proteins are chitinases. Proceedings of the National Academy of Sciences of the United States of America. 1987;84:6750-6754

[91] Nishizawa Y, Hibi T. Rice chitinase gene: cDNA cloning and stressinduced expression. Plant Science. 1991;76:211-218

[92] Kombrink E, Schröder M, Hahlbrock K. Several "pathogenesisrelated" proteins in potato are 1 , 3 - $\beta$-glucanases and chitinases. Proceedings of the National Academy of Sciences of the United States of America. 1988;85:782-786

[93] Nishizawa Y, Nishio Z, Nakazono K, et al. Enhanced resistance to blast (Magnaporthe grisea) in transgenic rice by constitutive expression of rice chitinase. Theoretical and Applied Genetics. 1999;99:383-390

[94] Vasanthaiah HKN, Basha SM, Katam R. Differential expression of chitinase and stilbene synthase genes in Florida hybrid bunch grapes to Elsinoe ampelina infection. Plant Growth Regulation. 2010;61(2):127-134 


\title{
Chapter 3
}

\section{Brassica oleracea Transformation}

\author{
Penny Hundleby and Monika Chhetry
}

\begin{abstract}
With easier access to genome sequences and genome editing technology over the last few years, transformation technologies are routinely being used now as a research tool for elucidating gene function. In this chapter, we outline a simple A. tumefaciens-mediated transformation method for the diploid brassica species B. oleracea, using a doubled haploid spring line called AG DH1012. This genotype has become our model genotype for training purposes and for most of our routine work, with a transformation efficiency of $25 \%$ (no. independent shoots/no. explants). This easy-to-follow protocol has made for a 100\% technology transfer success rate to other researchers and laboratories around the globe. In this chapter, we detail our method using 4-day-old cotyledonary explants, with a step-by-step guide and supplemented with an online video to show the explant and subsequent shoot isolation stages. The video helps to remove any ambiguity that written protocols sometimes have. Primary transgenics ready for DNA extraction and early molecular analysis can be generated within 5-7 weeks from explant isolation.
\end{abstract}

Keywords: Brassica oleracea, Agrobacterium tumefaciens, cotyledon, transformation, CRISPR, gene function, AG DH 1012

\section{Introduction}

The genus Brassica is known not only for its agricultural oilseed crops but also for the diverse array of horticultural crops it has to offer. When GM plant technologies first emerged in the early 1980s, with the first publication being tobacco in 1983 [1], it was not long before the success followed in Brassica with reports by the late 1980s/ early 1990s for all six of the major economically important species; B. rapa [2], B. oleracea [3], B. nigra [4], B. napus [5], B. juncea [6] and B. carinata [7]. Yet despite the considerable advances in methodologies that followed over the years [8-11], the routine transformation of Brassica remains highly genotype dependent, with some genotypes simply remaining recalcitrant to transformation. Several key factors affecting the Brassica transformation efficiency have been identified, including susceptibility to Agrobacterium [12] and in vitro tissue culture responses [13]. This has enabled us to screen large numbers of genotypes to identify the ones that fit our protocols, rather than tailoring methods for individual genotypes [14, 15]. For gene testing to become a routine procedure, it is important to identify the easy-to-transform genotypes, with reproducible transformation efficiencies, that respond well when handled by different users. This is especially important in the era of genome editing, which to date is still heavily reliant on the tissue culture transformation approaches in most cases. The frequency of genome edits is still relatively low in primary transgenics and 
therefore requires the generation and screening of large numbers of primary transgenics, to maximise the potential of identifying edits within the primary generation. The transformation protocol described in the current chapter was used in the first published report of CRISPR genome editing in Brassica [16], and methods associated with screening for CRISPR/Cas9 edits in this genotype are detailed in [17]. Since 2015, there has been a steady flow of publications using CRISPR in Brassica. The use of transformation/CRISPR as a tool for genetic improvement in Brassica has recently been reviewed [18]. The AG DH1012 B. oleracea spring genotype, detailed in this chapter, has a broccoli type phenotype and was recently used in a study to generate MYB28 knock outs, which were subsequently grown under field conditions and were the first CRISPR/Cas9 edited plants to enter field trials in the UK, regulated under the EU GMO Directive [19].

The current era of genome editing, and other new plant breeding technologies, to help address issues of climate change, sustainability and food security is an exciting time. For some countries simple edits, which result in a product indistinguishable to conventional mutagenesis, will see them freed from the regulatory burden associated with GMOs, and this will help to rapidly advance plant breeding. However, for Europe and other regions, the technology remains predominantly a research tool for helping to increase our understanding of gene function, as such easily assessable transformation methods and resources provide a valuable resource to researchers.

While access to written protocols is essential for the successful transfer of technology to different users, seeing the protocol in real time is invaluable as it removes a lot of the subjective interpretation of a written protocol. Within the methods section we provide a link to our YouTube video which shows the explant isolation and later shoot isolation steps of the protocol.

\section{Transformation method}

The protocol described below has been optimised for B. oleracea genotype AG DH1012 but has successfully been applied to many other $B$. oleracea genotypes and B. napus (using a slight higher BAP concentration for B. napus of $3.75 \mathrm{mg} / \mathrm{L}$ ). This protocol is based on a previously reported method for $B$. napus transformation [5], using 4-day-old cotyledonary petioles as the explant choice. A link to a video showing aspects of the transformation procedure can be found here (https://www. youtube.com/watch?v=cbtpCtc2lw0) or by Google search 'Brassica Transformation' YouTube John Innes Centre. Details of the stock solutions and media components used are detailed after the method, in Section 4.

\subsection{Plant material}

AG DH1012 is the B. oleracea genotype described in this chapter. AG DH1012 is a doubled haploid genotype from the Brassica oleracea ssp. alboglabra (A12DHd) crossed with B. oleracea ssp. italica (Green Duke GDDH33) mapping population [19]. AG DH1012 is a spring type and self-compatible. Seeds can be obtained from Dr Penny Hundleby from the Biotechnology Resources for Arable Crop Transformation group, at the John Innes Centre, UK. Cost recovery charges, for generating the seed, will apply.

\subsection{Seed sterilisation and germination}

In a flow bench, seeds are surface sterilised in $75 \%$ ethanol for 2 min followed by a $15 \%$ bleach sterilising solution ( $15 \mathrm{~mL}$ sodium hypochlorite [Sigma-Aldrich supplied at $10 \% \mathrm{RT}$ ] added to $85 \mathrm{~mL}$ distilled water with a drop (0.1\%) of surfactant 
Tween-20). Typically, $2 \mathrm{~g}$ of seed is used per transformation, and sterilised in a 5 -cm deep petri dish, or similar, and shaken on an orbital shaker for $15 \mathrm{~min}$. Seeds are rinsed three times with sterile distilled water to ensure no bleach remains and allowed to air dry before sowing. Seeds are placed (not embedded) onto germination medium at a density of $20-25$ seeds per $90 \mathrm{~mm}$ petri dish and sealed with a micropore tape. Plates are incubated at $22^{\circ} \mathrm{C}$ culture room under high intensity (full light) with a $16-\mathrm{h}$ photoperiod length of $70 \mu \mathrm{mol} / \mathrm{m}^{2} / \mathrm{s}$ for 4 days (i.e. sow seed on a Monday to transform on a Friday).

\subsection{Agrobacterium preparation and preparation of inoculum}

- A. tumefaciens strains containing the appropriate plasmid(s) with the gene(s) of interest are streaked out onto the solid LB medium containing the appropriate level of selection. Plates are incubated at $28^{\circ} \mathrm{C}$ for $48 \mathrm{~h}$. We routinely use $A$. tumefaciens strain AGL1 [20], see also Note 1.

- A single colony is transferred to $10 \mathrm{~mL}$ of a liquid $\mathrm{LB}$ medium containing selection and transferred to a $28^{\circ} \mathrm{C}$ shaker at $200 \mathrm{rpm}$ for $48 \mathrm{~h}$. After this stage, standard inoculums can be prepared for later use or proceed as follows.

- A $50 \mu \mathrm{L}$ aliquot of the resulting bacterial suspension is transferred to $10 \mathrm{~mL}$ of MGL liquid medium containing selection and grown over night in a $28^{\circ} \mathrm{C}$ shaker.

- Pellet the over-night cultures by centrifugation at approximately $3000 \mathrm{rpm}$ for $5 \mathrm{~min}$ and resuspend the pellet in a liquid MS medium, dilute to an $\mathrm{OD}_{600}=0.1-0.3$.

- Alternatively, we make up 'standard inoculums' from the resulting LB cultures; using $2 \mathrm{~mL}$ of culture to $2 \mathrm{~mL}$ of $50 \%$ glycerol. Gently mix by inverting the tube upside down, several times, aliquot $200 \mu \mathrm{l}$ in each $0.5 \mu \mathrm{l}$ tubes and store at $-80^{\circ} \mathrm{C}$ until required. To use, $50 \mu \mathrm{l}$ of a standard inoculum is added to $10 \mathrm{~mL}$ of MGL media without selection and grown overnight in a $28^{\circ} \mathrm{C}$ shaker at $200 \mathrm{rpm}$.

- Dilute the overnight suspension with liquid MS media to an $\mathrm{OD}_{600}=0.1-0.3$. Typically, $1 \mathrm{~mL}$ of the overnight culture with $5 \mathrm{~mL}$ of MS liquid will give an OD within this range.

\subsection{Explant isolation, inoculation and co-cultivation}

Cotyledons are excised from 4-day-old seedlings by gently holding the base of the cotyledon with forceps (Dumont No 24/45) and slicing across the petiole just above the meristematic region using a sharp scalpel blade (surgical blades No. 11) aiming for a petiole length of approximately 1-2 mm, see Figure 1. Avoid taking any meristematic tissue as it does not transform easily and will regenerate 'escape' shoots rapidly on the selection medium.

Explants are immediately placed onto co-cultivation medium in petri dishes $(20 \times 90 \mathrm{~mm})$ ensuring that at least $1-2 \mathrm{~mm}$ of the cut petiole is implanted into the agar. Place at a density of approximately 10 explants/plate. Once all explants have been isolated, explants are then removed from the media individually and dipped briefly into an Agrobacterium suspension, ensuring only the cut end of the petiole is immersed (see video). Two control plates are set up per experiment, each with 10 explants. For one plate, explants are inoculated, and for the other plate, explants are not inoculated with $A$. tumefaciens. 

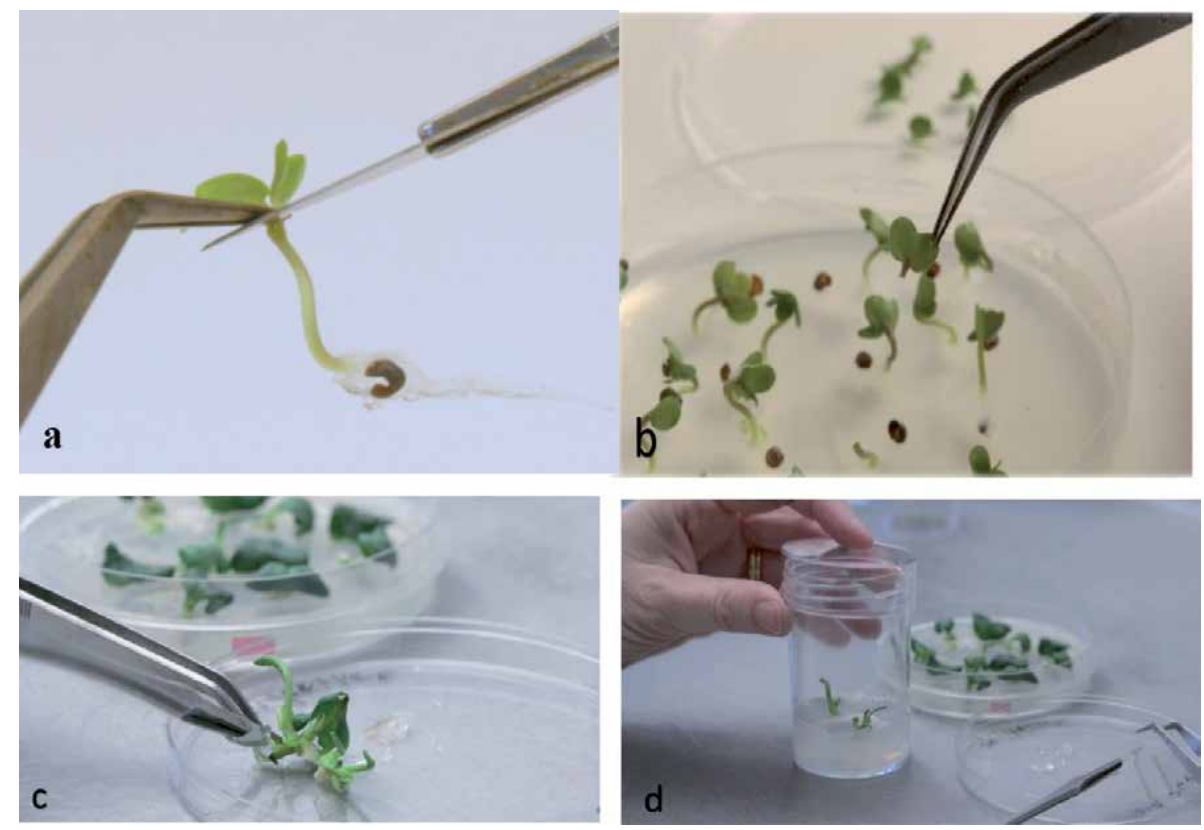

Figure 1.

(a) Explant isolation from 4-day-old seedlings. Forceps are used to hold the seedling without pressure and used as a guide to run the scalpel blade down. (b) Cotyledons with approximately 1-2 $\mathrm{mm}$ of petiole are used as explants. The petiole base is later inoculated by dipping briefly in Agrobacterium. (c) Putative transgenic green shoot forming at approximately 4 weeks from a small callus at the petiole base; $(d)$ shoots are isolated and transferred to rooting medium.

All cotyledons are then returned to co-cultivation plates and sealed with micropore tape and transferred to a $22^{\circ} \mathrm{C}$ culture room with a 16 -h photoperiod of 40 $\mu \mathrm{mol} / \mathrm{m}^{2} / \mathrm{s}$ for $72 \mathrm{~h}$.

\subsection{Selection}

- After co-cultivation, cotyledons are transferred to selection medium in deep petri dishes $(20 \times 90 \mathrm{~mm})$. Plates are sealed with a micropore tape and returned to the culture room under scattered light.

- For each experiment, two control plates (as selection plates but with no kanamycin) are established; one contains 10 explants that have not been inoculated with Agrobacterium, and the other 10 explants that have been inoculated.

- Explants are transferred to fresh selection medium after 3 weeks. During this subculture, any white shoots (escapes) are removed.

\subsection{Shoot isolation}

- When using AG DH1012, the emergence of transgenic (green) shoots can be seen after just 3 weeks. After $3-5$ weeks, transgenic shoots can be excised and transferred to $100 \mathrm{~mL}$ jars $(75 \times 50 \mathrm{~mm})$, containing $25 \mathrm{~mL}$ of Gamborgs B5 medium, containing $25 \mathrm{mg} / \mathrm{L}$ kanamycin and $160 \mathrm{mg} / \mathrm{L}$ Timentin, and maintained at $22^{\circ} \mathrm{C}$ under 16-h day length of $40 \mu \mathrm{mol} / \mathrm{m}^{2} / \mathrm{s}$. In some cases, further subculture maybe needed to 'thin' out multiple shoots to ensure a single-stemmed shoot is allowed to root. This will reduce the number of multi-stemmed plants transferred to the 
glasshouse and the likelihood of escapes/chimeras going through. Such plants will complicate the molecular analysis of the primary transgenics.

- After root elongation (to approximately $20 \mathrm{~mm}$ in length), plantlets are transferred to sterile peat pods (Jiffy No. 7) in magentas (Stratlab Laboratories Supplies) SPL Life Sciences, (Cat no 451-AA-002/004) to allow further root growth (approx. 2 weeks) before being transferred to the glasshouse.

\section{Transfer of plants to the glasshouse and seed generation}

- Plants are transferred to soil and maintained under shade within a propagator for the first week. This ensures that plants gradually adjust to reduced humidity and increased light intensity. Glasshouse light conditions; day/night temperatures of $18 / 12 \pm 2^{\circ} \mathrm{C}, 16 \mathrm{~h}$ day length, with supplementary lighting (high-pressure sodium lamps with an average bench reading of $200 \mu \mathrm{mol} /$ $\mathrm{m}^{2} / \mathrm{s}$ ). Plants are fed weekly with a 2:1:1 NPK fertiliser.

- AG DH1012 is a rapid cycling genotype and should flower approximately 6-8 weeks after transfer. This line is also highly self-compatible and readily sets seed (approximately 8-10 weeks after bud break) without the need for hand pollination (see Figure 2).

- When in bud, plants are covered with clear, perforated 'bread' bags (Cryovac (UK) Ltd), to prevent cross-pollination, and shaken daily once in flower to encourage the seed set. Pods are allowed to dry on the plant before being threshed. Seed yield is generally high ( $>4 \mathrm{~g} /$ plant for wild type plants, or subsequent transgenic plants sown from seed; however, seed yield can often be reduced in the primary transgenics to in the region of $0.5-4 \mathrm{~g} /$ plant).
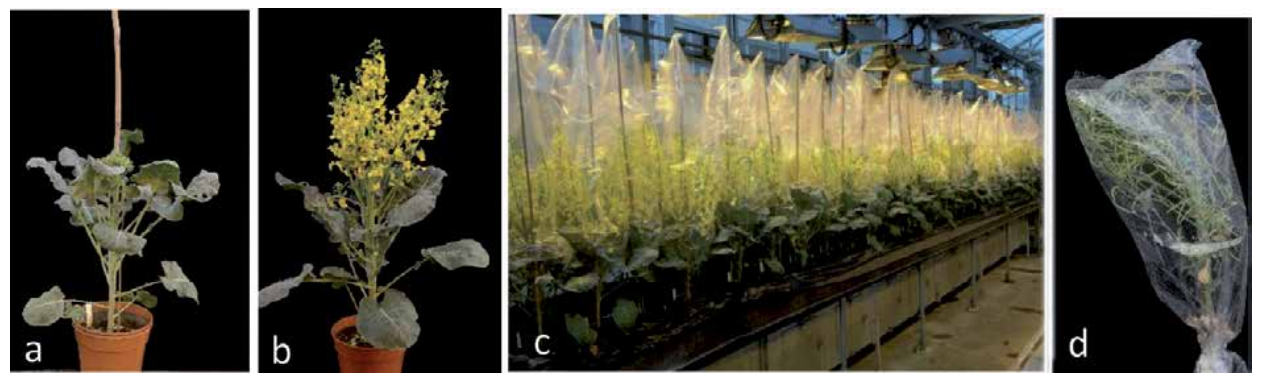

Figure 2.

Images show the phenotype of the Brassica oleracea genotype AG DH1012; (a) bud formation (broccoli type phenotype); (b) flowering; (c) bagged transgenics flowering in the glasshouse; $(d)$ seed set-in this image pods are still green, when approximately half the pods start to brown watering is stopped.

\section{Stock solutions and media}

\subsection{Antibiotic stock solutions}

- Kanamycin monosulphate stock solution (Sigma K1377): 100 mg/mL (2.5 g dissolved in minimal $1 \mathrm{M} \mathrm{NaOH}$ and made up to $25 \mathrm{~mL}$ with sterile distilled water (SDW) filter-sterilise and store in $1 \mathrm{~mL}$ aliquots in sterile $1.5 \mathrm{~mL}$ tubes at $-20^{\circ} \mathrm{C}$ ). 
- Timentin stock solution [sold as Ticarcillin disodium/clavulanate potassium (Duchefa T0190)]: $160 \mathrm{mg} / \mathrm{mL}$ (2 g dissolved in $12.5 \mathrm{~mL}$ SDW) filter-sterilise and store in $1 \mathrm{~mL}$ aliquots in sterile $1.5 \mathrm{~mL}$ tubes at $-20^{\circ} \mathrm{C}$.

- Augmentin stock solution [sold as Amoxicillin sodium/clavulanate potassium (Duchefa A0189)]: $600 \mathrm{mg} / \mathrm{ml}$ and $300 \mathrm{mg} / \mathrm{ml}$, filter-sterilise, store in $1 \mathrm{~mL}$ aliquots in sterile $1.5 \mathrm{~mL}$ tubes, and prepare just before use (see Note 2).

\subsection{Plant culture media and components}

- 6-Benzylaminopurine (BAP) stock solution: $4 \mathrm{mg} / \mathrm{mL}$. We prepare by dissolving $0.1 \mathrm{~g}$ of powder in minimal drops of $1 \mathrm{M} \mathrm{NaOH}$. Make to final volume of $25 \mathrm{~mL}$ with sterile distilled water (SDW). Store at $4^{\circ} \mathrm{C}$.

- MS Basal medium + 2 mg/L BAP: $4.3 \mathrm{~g} / \mathrm{L}$ Murashige and Skoog (MS) salts (Duchefa, M0221) supplied without vitamins, $30 \mathrm{~g} / \mathrm{L}$ Sucrose, $2 \mathrm{mg} / \mathrm{L}$ BAP (add $500 \mu \mathrm{l}$ of BAP $4 \mathrm{mg} / \mathrm{L}$ stock), $500 \mathrm{mg} / \mathrm{L} 2$-(N-morpholino) ethanesulfonic acid (MES), $\mathrm{pH} 5.7$, and $8 \mathrm{~g} / \mathrm{L}$ phytagar (Duchefa P1003). Autoclave at $120^{\circ} \mathrm{C}$ for $20 \mathrm{~min}$ (see Note 3 ).

- Vitamin stocks: prepare $10 \mathrm{mg} / \mathrm{mL}$ Thiamine HCL, $1 \mathrm{mg} / \mathrm{mL}$ Pyridoxine, $1 \mathrm{mg} /$ $\mathrm{mL}$ Nicotinic acid and $100 \mathrm{mg} / \mathrm{mL}$ myo-inositol in SDW, and filter-sterilise. Store individually at $4^{\circ} \mathrm{C}$ except $m y o$-inositol, which is stored at room temperature.

- Germination medium: MS including vitamins (M0222, Duchefa) $4.41 \mathrm{~g} / \mathrm{L}$, Glucose 1 g/L, 500 mg/L MES, 10 g/L Difco Bacto Agar (214,030, Becton Dickinson, Thermofischer), adjust $\mathrm{pH}$ to 5.7, autoclave (see Note 4).

- Co-cultivation medium: To the MS basal medium + 2BAP detailed above: add $1 \mathrm{~mL}$ each of the four vitamin stocks. One litre makes around 40 petri dishes (90 mm single vent, Slaughter Ltd, R\&L).

- Selection medium: add $160 \mathrm{mg} / \mathrm{L}$ Timentin (1 mL Timentin stock) and $15 \mathrm{mg} / \mathrm{L}$ Kanamycin $(150 \mu \mathrm{L}$ of $100 \mathrm{mg} / \mathrm{mL}$ kanamycin stock) to $1 \mathrm{~L}$ of co-cultivation media and pour in petri dishes $(100 \times 20 \mathrm{~mm}$ STD, Sarstedt Limited $)$. Alternatively replace Timentin with Augmentin at $600 \mathrm{mg} / \mathrm{ml}$ dropping to $300 \mathrm{mg} / \mathrm{ml}$ at later subcultures. One litre is enough for 20 petri dishes. The two control plates can be poured from a $1 \mathrm{~L}$ flask of media before the kanamycin is added.

- Rooting medium: (B5 + 1\% Sucrose). 3.05 g/L Gamborg B5 salts (Duchefa, G0209), 10 g/L Sucrose and 8 g/L Phyto agar (Duchefa P1003). Adjust pH to 5.8 with $1 \mathrm{M} \mathrm{KOH}$ and autoclave. Prior to pouring add filter-sterilised $160 \mathrm{mg} / \mathrm{L}$ Timentin and $25 \mathrm{mg} / \mathrm{L}$ Kanamycin. Raising the selection level from 15 to $25 \mathrm{mg} / \mathrm{L}$ reduces further the number of escapes that occur.

All media detailed above can be allowed to set and microwaved to re-melt if not poured immediately.

\subsection{Agrobacterium culture media}

- LB solid medium: 5 g/L Yeast Extract, 10 g/L NaCl, 10 g/L Tryptone and $15 \mathrm{~g} / \mathrm{L}$ Bactoagar; autoclave at $120^{\circ} \mathrm{C}$ for $20 \mathrm{~min}$. 
- LB liquid medium: 5 g/L Yeast Extract, 10 g/L NaCl, 10 g/L Tryptone and dispense into $10 \mathrm{~mL}$ aliquots. Autoclave at $120^{\circ} \mathrm{C}$ for $20 \mathrm{~min}$.

- MGL liquid medium: 5 g/L Tryptone, $2.5 \mathrm{~g} / \mathrm{L}$ Yeast, $100 \mathrm{mg} / \mathrm{L} \mathrm{NaCl}, 5 \mathrm{~g} / \mathrm{L}$ Mannitol, 1 g Glutamic acid, 250 mg/L $\mathrm{KH}_{2} \mathrm{PO}_{4}, 100 \mathrm{mg} / \mathrm{L} \mathrm{MgSO}_{4}, 1 \mu \mathrm{g} / \mathrm{L}$ Biotin and $\mathrm{pH} 7$.

- MS Liquid medium: 4.3 g/L Murashige and Skoog (MS) salts, 30 g/L Sucrose, and $\mathrm{pH} 5.7$ dispense into $100 \mathrm{~mL}$ aliquots. Autoclave at $120^{\circ} \mathrm{C}$ for $20 \mathrm{~min}$.

\section{Notes}

1. AGL1 is the Agrobacterium tumefaciens strain routinely used in our lab in conjunction with the pBRACT series of vectors. LBA 4404, EHA101 and EHA105 are also suitable Agrobacterium strains with other plasmids such as pCAM2200 (from the pCAMBIA series) and the SLJ vectors SLJ1714 and SLJ1711.

2. Augmentin should preferably be made up fresh before use. However, it can be stored frozen and defrosted once. Prolonged storage will see a discoloration from pale yellow to dark brown.

3. MS salts with vitamins are available commercially in combination or separate. We prefer to use MS Salts without vitamins from Duchefa, and make up fresh Gamborg's B5 vitamins to add prior to pouring. However, we have also used MS salts with MS vitamins (M0221) and understand that MS medium including Gamborg's B5 vitamins (M0231) is also available. We believe adding vitamins after autoclaving maybe preferable, but we have not carried out enough direct comparisons to see if it significantly makes a difference.

4. Our in-house Arabidopsis germination media is used, for convenience, to germinate Brassica seeds. We have used a range of different germination media in the past successfully and believe it is the size of the seedling on the day of explant isolation that is most critical.

\section{Conclusion}

Access to easy-to-follow and reproducible transformation protocols is highly desirable. The authors aim is that the protocol described in this chapter, when read in conjunction with watching the video, will help to demystify those specialist skills often associated with tissue culture success.

\section{Acknowledgements}

We acknowledge and thank Ruby O'Grady from the communications team at the John Innes Centre for filming and editing of the transformation video referenced in this chapter. We acknowledge funding support from the Biotechnology and Biological Sciences Research Council (BBSRC) Institute Strategic Programmes GRO [BB/J004588/1] and GEN [BB/P013511/1] to the John Innes Centre. Further illustrative photographs of the transformation of B. oleracea DH1012 can be seen at https://www.jic.ac.uk/research-impact/technology-platforms/genomic-services/ 
crop-transformation/ together with a list of construct resources also available. These transformation resources were developed as part of the Biotechnology Resources for Arable Crop Transformation (BRACT) facility, initially funded by Defra (UK) and now operating on a cost-recovery basis as a transformation resource for the research community.

\section{Conflict of interest}

The authors declare there is no 'conflict of interest'.

\section{Author details}

Penny Hundleby* and Monika Chhetry

John Innes Centre, Norwich Research Park, Norwich, UK

*Address all correspondence to: penny.hundleby@jic.ac.uk

\section{IntechOpen}

(C) 2020 The Author(s). Licensee IntechOpen. This chapter is distributed under the terms of the Creative Commons Attribution License (http://creativecommons.org/licenses/ by/3.0), which permits unrestricted use, distribution, and reproduction in any medium, provided the original work is properly cited. (cc) BY 


\section{References}

[1] Bevan MW, Flavell RB, Chilton MD. A chimeric antibiotic resistance gene as a selectable marker for plant cell transformation. Nature. 1983;304:184-187

[2] Barfield DG, Pua EC. Gene transfer in plants of Brassica juncea using Agrobacterium tumefaciens-mediated transformation. Plant Cell Reports. 1991;10:308-314

[3] Moloney MM, Walker JM, Sharma KK. High-efficiency transformation of Brassica napus using Agrobacterium vectors. Plant Cell Reports. 1989;8:238-242

[4] Radke SE, Turner JC, Facciotti D. Transformation and regeneration of Brassica rapa using Agrobacterium tumefaciens. Plant Cell Reports. 1992;11: 499-505

[5] De Block M, Tenning P,

De Brouwer D. Transformation of Brassica napus and Brassica oleracea using Agrobacterium tumefaciens and the expression of the bar and neo genes in the transgenic plants. Plant Physiology. 1989;91:694-701

[6] Gupta V, Lakshmi Sita G, Shaila MS, Jagannathan V. Genetic transformation of Brassica nigra by Agrobacterium based vector and direct plasmid uptake. Plant Cell Reports. 1993;12:418-421

[7] Narasimhulu SB, Kirti PB, Mohapatra T, Prakash S, Chopra VL. Shoot regeneration in stem explants and its amenability to Agrobacterium tumefaciens mediated gene transfer in Brassica carinata. Plant Cell Reports. 1992;11:359-362

[8] Cardoza V, Stewart N. Canola (Brassica napus L.). In: Wang K, editor. Agrobacterium Protocols. 2nd ed. Vol. 1. Methods in Molecular Biology 343. Totowa, New Jersey: Humana Press; 2006. pp. 257-266
[9] Gasic K, Korban SS. Indian mustard [Brassica juncea (L.) Czern]. In: Wang K, editor. Agrobacterium Protocols. 2nd ed. Vol. 1. Methods in Molecular Biology 343. Totowa, New Jersey: Humana Press; 2006. pp. 281-289

[10] Bhalla PL, Singh M. Agrobacteriummediated transformation of Brassica napus and Brassica oleracea. Nature Protocols. 2008;2:181-189

[11] Hundleby PA, Irwin JA. Brassica oleracea and B. napus. In: Wang K, editor. Agrobacterium Protocols. 3rd ed. Vol. 1. Methods in Molecular Biology 1223. London: Springer, Humana Press; 2015. pp. 287-297

[12] Sparrow PAC, Townsend T, Arthur AE, Dale PJ, Irwin JA. Genetic analysis of Agrobacterium tumefaciens susceptibility in Brassica olevacea. Theoretical and Applied Genetics. 2004;108:664-650

[13] Sparrow PAC, Townsend T, Morgan CL, Arthur AE, Dale PJ, Irwin JA. Genetic analysis of in vitro shoot regeneration from cotyledonary petioles of Brassica oleracea.

Theoretical and Applied Genetics. 2004;108:1249-1255

[14] Sparrow PAC, Dale PJ, Irwin JA. The use of phenotypic markers to identify Brassica oleracea genotypes for routine high-throughput Agrobacteriummediated transformation. Plant Cell Reports. 2004;23:64-70

[15] Sparrow PAC, Snape JW, Dale PJ, Irwin JA. The rapid identification of $B$. napus genotypes, for high-throughput transformation, using phenotypic tissue culture markers. Acta Horticulture. 2006;706:239-247

[16] Lawrenson T, Shorinola O, Stacey N, et al. Induction of targeted, heritable mutations in barley and Brassica oleracea 
using RNA-guided Cas9 nuclease.

Genome Biology. 2015;16:258. DOI:

10.1186/s 13059-015-0826-7

[17] Lawrenson T, Hundleby P, Harwood W. Creating targeted gene knockouts in Brassica oleracea using CRISPR/Cas9. In: Qi Y, editor. Plant Genome Editing with CRISPR Systems. Methods in Molecular Biology. Vol. 1917. New York, London: Springer Nature/ Humana Press; 2019. pp. 155-170. DOI: 10.1007/978-1-4939-8991-1_12

[18] Rustagi A, Negi NP, Choudhury HD, Mahajan A, Rekha S, Verma S, et al. Transgenic approaches for improvement of Brassica species. In: Wani S, Thakur A, Jeshima Khan Y, editors. Brasica Improvement. Cham: Springer; 2020. pp. 187-213. DOI: 10.1007/978-3-030-34694-2_10

[19] Neequaye M, Stavnstrup S, Lawrenson T, Hundleby P, Troncoso-Rey P, Saha S et al. CRISPRCas9 mediated editing of myb28 impairs glucoraphanin accumulation of $B$. oleracea in the field. bioRxiv. DOI: 10.1101/2020.07.16.206813

[20] Bouhuon EJR, Keith DJ, Parkin IAP, Sharpe AG, Lydiate DJ. Alignment of the conserved C genomes of Brassica oleracea and Brassica napus. Theoretical and Applied Genetics. 1996;93:833-839 


\title{
Construction and Evaluation of Chloroplast Expression Vectors in Higher Plants
}

\author{
Po-Yen Chen, Yung-Ting Tsai and Kin-Ying To
}

\begin{abstract}
Plastid transformation has a number of advantages in comparison with nuclear transformation. Currently, only tobacco (Nicotiana tabacum) is routinely used in plastid transformation. Here we constructed a series of chloroplast expression vectors specific for spinach (pCEV1), tomato (pCEV2 and pCEV3), and $N$. benthamiana (pCEV4). Selection marker aminoglycoside $3^{\prime}$-adenyltransferase (adA) conferring spectinomycin resistance was used in pCEV1, pCEV2, and pCEV4, while selection marker neomycin phosphotransferase II (nptII) was used in pCEV3. The expression cassette in these vectors was integrated in the intergenic spacer between $t r n I$ and $\operatorname{trn} A$ of plastid genome via homologous recombination. Several transgenes, including a reporter gene encoding GFP:GUS fusion protein and genes from tomato (lycopene b-cyclase, z-carotene desaturase) and bamboo mosaic virus satellite RNA (encoding coat protein CP20), were independently cloned into some of these vectors. Transient GUS expression was detected in spinach leaves bombarded by pCEV1/GFP-GUS. Functional expression of selection markers aadA and nptII was demonstrated for spinach, tomato, and $N$. benthamiana. Seedling assay from $\mathrm{T}_{0}$ self-pollinated plant of transplastomic $N$. benthamiana confirmed maternal inheritance of transgenes, and genomic PCR analysis confirmed integration of transgenic expression cassette into the plastid genome of $N$. benthamiana. Moreover, auxiliary vectors pECaad and pECnpt are also reported.
\end{abstract}

Keywords: bombardment, chloroplast transformation, homologous recombination, plastid transformation, transplastomic plant, vector construction

\section{Introduction}

Plastid transformation has a number of advantages in comparison with nuclear transformation. It has high levels of transgene expression, position effect or gene silencing is not found due to precise integration of the transgene into the host plastid genome via homologous recombination, and further, gene flow through pollen is not an issue due to maternal inheritance. Plastid transformation technology is important for analyzing the functions of chloroplast genes and has also been 
widely used in mass production of foreign proteins for agronomic traits (such as insect resistance, herbicide resistance, disease resistance, drought resistance, salt resistance, phytoremediation, etc.), enzymes/biomaterials (such as cellulase, endo-glucanase, monellin, polyhydroxybutyrate, xylanase, $\beta$-glucosidase, pectin lyase, manganese peroxidase, superoxide dismutase, etc.), and pharmaceuticals/ vaccine antigens (such as interferon- $\gamma$, human serum albumin, human somatotropin, insulin-like growth factor, thioredoxin 1, basic fibroblast growth factor, aprotinin, cholera toxin, tetanus toxin, Canine parvovirus, anthrax protective antigen, dengue virus, etc.) over the past few decades [1-6]. In most cases, only tobacco (Nicotiana tabacum) is routinely chosen as a target plant in plastid transformation [1]. Besides tobacco, a few studies using tomato, lettuce, oilseed rape, potato, cabbage, cotton, carrot, $N$. benthamiana, etc., as target plants have also been reported to produce foreign proteins by plastid transformation technology [1-5, 7-10].

In nuclear transformation, one nuclear transformation vector can be applied to multiple plants. For example, a nuclear transformation vector $\mathrm{pCHS}$ [carrying the expression cassette for the selection marker neomycin phosphotransferase II (nptII) driven by nopaline synthase (nos) promoter and Petunia chalcone synthase (chs) driven by cauliflower mosaic virus 35S promoter] and an Agrobacterium tumefaciensmediated method were employed to a range of plant species including the highvalue medicinal plants Echinacea purpurea [11] and E. pallida [12], model plant tobacco [13], medicinal herb Bidens pilosa [14], and the floricultural plant Cleome spinosa [15]; the transfer DNA (T-DNA) containing the expression cassette in vector pCHS was integrated randomly in the nuclear chromosome of transgenic plants, and the foreign Petunia chs and selection marker nptII were detected and expressed. However, in plastid transformation, a plastid transformation vector has to be constructed for each target plant which is quite a laborious work. A typical plastid transformation vector consists of two components: (1) an expression cassette [a gene of interest (GOI) which is inserted between the plastid promoter and the plastid terminator, followed by a selection marker gene which is inserted between the plastid promoter and the plastid terminator] and (2) a targeting sequence for homologous recombination in the host plant plastid genome. The expression cassette is located between the left targeting region (LTR) and the right targeting region (RTR) in the vector, and this expression cassette is expected to integrate into the plastid genome of the host plant through double homologous recombination during plastid transformation [1,3-5]. Thus, in comparison with random insertion in nuclear transformation, the expression cassette is precisely inserted at the predicted integration site of the plastid genome during plastid transformation. In theory, any plastid DNA fragment within the plant plastid genome can serve as a targeting region in plastid transformation, and the integration site for the foreign expression cassette into the plant plastid genome can be anywhere within the targeting region. In practice, only 10 or so plastid DNA sequences have been chosen as targeting regions in plastid transformation [3]. Among them, the plastid trnI/ $\operatorname{trn} A$ sequence is the most frequently used as a targeting region, and the spacer between $\operatorname{trnI}$ and $\operatorname{trn} A$ is the most frequently used as the integration site $[1,3]$. In addition, the selection marker aminoglycoside 3 -adenyltransferase ( $\operatorname{add} A)$ conferring resistance to spectinomycin or streptomycin is most frequently used in plastid transformation, although other selection markers such as antibiotic resistance (including nptII), herbicide resistance, photosynthesis, and metabolism have been reported [16]. More recently, a new selection marker, namely, aminoglycoside acetyltransferase/phosphotransferase, conferring tobramycin in tobacco plastid transformation has been developed [17]. 
Spinach (Spinacia oleracea), belonging to Chenopodiacea, is a leaf vegetable which is an important source of vitamins and other essential nutrients in many countries. Callus induction and plant regeneration from different explants including leaves, cotyledons, and hypocotyls of several commercial spinach cultivars have been reported $[18,19]$. For nuclear transformation, an Agrobacterium-mediated method was reported from leaf and hypocotyl explants of spinach cultivars Fall Green and High Pack, and transgenic spinach plants expressing cucumber mosaic virus coat protein were obtained [20]. In addition, Agrobacterium-mediated transformation was also established from cotyledon explants of spinach cultivars Longstanding Bloomsdale and Melody, and transgenic spinach plants expressing reporter gene encoding green fluorescent protein (GFP) were regenerated [21]. However with regard to plastid transformation, although the complete chloroplast genome of spinach has been published [22], plastid transformation in spinach has not yet been reported. To initiate plastid transformation in spinach, we constructed chloroplast expression vectors specific for spinach. During the construction, we found that we can easily replace the host plant targeting sequence, which is crucial for homologous recombination in plastid transformation, from spinach to other plant species. Tomato (Solanum lycopersicum) was chosen as another target plant in this study, since tomato is an important foodstuff worldwide. Although plastid transformation was reported in tomato cultivar Santa Clara [7], we still wanted to set up plastid transformation technology for tomato cultivar CL5915, a local Taiwan cultivar. N. benthamiana was the third target plant in this study. Similar to the widely used tobacco ( $N$. tabacum), N. benthamiana has many advantages in cell culture such as being easy to regenerate, short lifetime, and self-pollination. Two more advantages in comparison with $N$. tabacum are the plant height and leaf size which are much reduced in $N$. benthamiana, allowing it to serve as model plant for fundamental research such as studies of host/virus interactions.

We want to set up chloroplast transformation technology in our laboratory. As a first step in achieving the goal, we need to construct various chloroplast expression vectors for different plant species. Here we describe the efficient construction of a series of chloroplast expression vectors specific for spinach (pCEV1), tomato (pCEV2 and pCEV3), and N. benthamiana (pCEV4). Selection marker aadA conferring spectinomycin resistance was used in pCEV1, pCEV2, and pCEV4, while selection marker $n p t I I$ conferring kanamycin resistance was used in pCEV3. Subsequently, several transgenes, including reporter gene encoding GFP:GUS fusion protein and genes from tomato [lycopene $\beta$-cyclase (LCY), $\zeta$-carotene desaturase (ZDS)] and bamboo mosaic virus satellite RNA (encoding coat protein CP20), were independently cloned into some of these vectors. The reporter gene encoding GFP: GUS fusion protein was inserted into all plastid vectors, so that the expression of the transgene can be visualized by GFP fluorescence microscopy or GUS staining. LCY and ZDS are key enzymes in the carotenoid biosynthesis pathway. Previously, a few genes including $L C Y$ and $Z D S$ have been cloned from tomato in our laboratory [23]. In this study, $L C Y$ and $Z D S$ were selectively inserted into pCEV1 to investigate whether we can engineer spinach by using plastid transformation technology. CP20, encoded by bamboo mosaic virus satellite RNA, is the RNA-binding protein essential for virus infection of the host plant [24]. Thus, the coding region of CP20 with or without untranslated regions was inserted into PCEV4 for $N$. benthamiana. Accuracy of cloning GOI into these vectors has been demonstrated, and functional expressions of reporter and selection marker genes have also been confirmed. In addition, we further report two auxiliary vectors pECaad (carrying selection marker $\operatorname{aad} A$ ) and pECnpt (carrying selection marker $n p t I I$ ) which may facilitate vector construction in other plant species. 


\section{Materials and methods}

\subsection{Plant material and culture conditions}

Seeds of spinach (Spinacia oleracea), tomato (Solanum lycopersicum var. CL5915), tobacco (Nicotiana tabacum var. W38), and N. benthamiana were individually sterilized by sequential treatment with $70 \%$ ethanol for $0.5 \mathrm{~min}$ and $1 \%$ sodium hypochlorite for $10 \mathrm{~min}$, then washed thoroughly with sterile water, and germinated on MS basal medium (MS salts [25]; 3\% sucrose; $0.8 \%$ Bacto agar; $\mathrm{pH}$ 5.7). The cultures were then incubated in a growth chamber at $22^{\circ} \mathrm{C}$ under a photoperiod of $16 \mathrm{~h}$ illumination $\left(100 \mu \mathrm{mol} \mathrm{m} \mathrm{m}^{-2} \mathrm{~s}^{-1}\right)$ and $8 \mathrm{~h}$ darkness. In vitro explants were used to establish the plant regeneration and plastid transformation.

\subsection{Construction of chloroplast expression vector pCEV1}

Schematic representation of the cloning procedure used to obtain a chloroplast expression vector in this study is shown in Figure 1, and the list of the relevant primers used in this study is shown in Table A1. Genomic DNA from green leaves of the target plants was isolated by the cetyltrimethyammonium bromide (CTAB) method [26]. DNA fragments of Prrn, TpsbA, PatpI, and Trps16 were amplified in $50 \mu \mathrm{l}$ PCR mixture [1× PCR buffer; $200 \mu \mathrm{M}$ dNPT; $0.5 \mu \mathrm{M}$ each of gene-specific forward and reverse primers; $500 \mathrm{ng}$ tobacco (N. tabacum) genomic DNA; $2.5 \mathrm{U}$ FastTaq DNA polymerase]. The PCR mixture was denatured at $94^{\circ} \mathrm{C}$ for 5 min prior to 35 amplification cycles $\left(1 \mathrm{~min}\right.$ at $94^{\circ} \mathrm{C}, 1 \mathrm{~min}$ at $55^{\circ} \mathrm{C}, 1 \mathrm{~min}$ at $\left.72^{\circ} \mathrm{C}\right)$. Final extension reaction was performed at $72^{\circ} \mathrm{C}$ for $10 \mathrm{~min}$. Following amplification, PCR

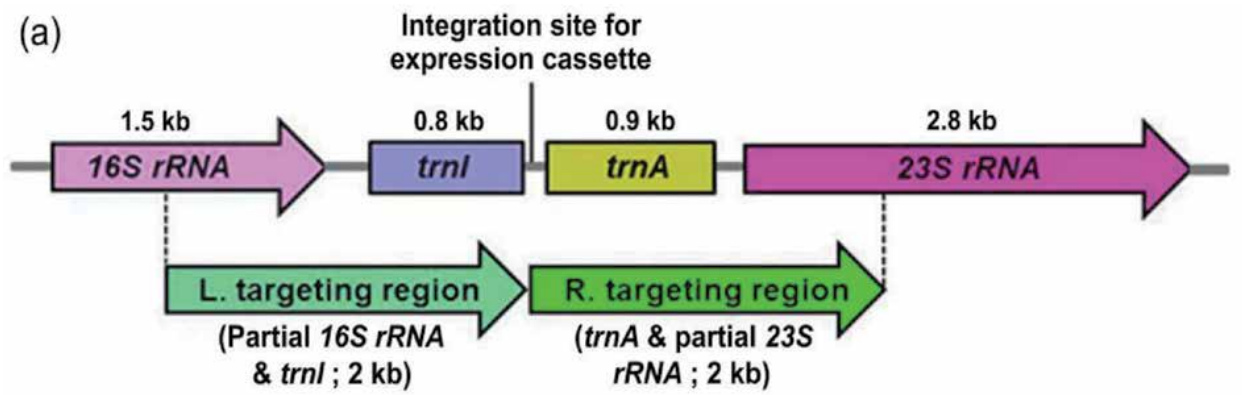

(b)

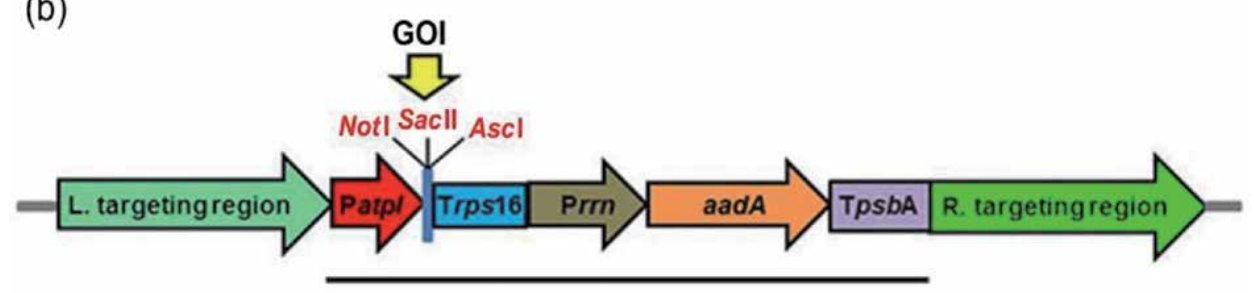

Expression cassette

Figure 1.

Schematic representation of the targeting region, integration site, and expression cassette in the chloroplast expression vector. (a) Diagram showing chloroplast targeting sequence for homologous recombination. Left targeting region (ca. $2 \mathrm{~kb}$ ) was composed of partial $16 \mathrm{~S} \mathrm{rRNA}$ and trnI, while the right targeting region (ca. $2 \mathrm{~kb}$ ) was composed of trnA and partial $23 \mathrm{~S}$ rRNA. Integration site for expression cassette was designed at the intergenic spacer between trnI and trnA. (b) Diagram showing the expression cassette between the left targeting region and the right targeting region. The expression cassette was composed of the synthetic unique cloning sites (NotI, SacII, AscI) which were inserted between atpI promoter and $\mathrm{rps} 16$ terminator, followed by selection marker aadA which was inserted between rrn promoter and psbA terminator. Gene of interest (GOI) can be inserted into the expression cassette at the cloning sites. 
products were analyzed on a $1 \%$ agarose gel, and PCR fragments were cut out of the gel, purified by the Zymoclean gel DNA recovery kit (Zymo Research, Orange, CA, USA), cloned into pGEM-T Easy vector (3015 bp; Promega), and then sequenced by an automatic DNA sequencer (ABI PRISM 377 DNA Sequencer, PerkinElmer). Stepwise protocols for cloning pCEV1 (Figure 2) were as follows.

\subsubsection{Cloning of Prrn-aadA-TpsbA fragment into pUC19}

a. TpsbA (222 bp) was inserted into pUC19: As mentioned above, PCR amplification was carried out using TpsbA-F (containing XbaI site) and TpsbA-R (containing PstI site) as primers and $500 \mathrm{ng}$ tobacco genomic DNA as template. After PCR amplification, PCR products were purified and cloned into pGEM-T Easy vector. Plasmid carrying XbaI-TpsbA-PstI was isolated and double digested by XbaI and PstI and then ligated with pUC19 (2686 bp; New England Biolabs) which was double digested by $\mathrm{XbaI}$ and Pst I, resulting in pUC19/TpsbA.

b. Prrn (219 bp) was inserted into pUC19/TpsbA: PCR amplification was carried out using Prrn-F (containing the KpnI site) and Prrn-R (containing the Bam HI site) as primers and $500 \mathrm{ng}$ tobacco genomic DNA as template. After PCR amplification, PCR products were purified and cloned into pGEM-T Easy vector. Plasmid carrying KpnI-Prrn-Bam HI was isolated and doubled digested by KpnI and BamHI and then ligated with pUC19/TpsbA which was double digested by KpnI and BamHI, resulting in pUC19/Prrn-TpsbA.

c. aadA (792 bp) was inserted between Prrn and TpsbA in pUC19: PCR amplification was carried out using aadA-F (containing the Bam HI site) and aadA-R (containing the XbaI site) as primers and $500 \mathrm{ng}$ plasmid DNA of
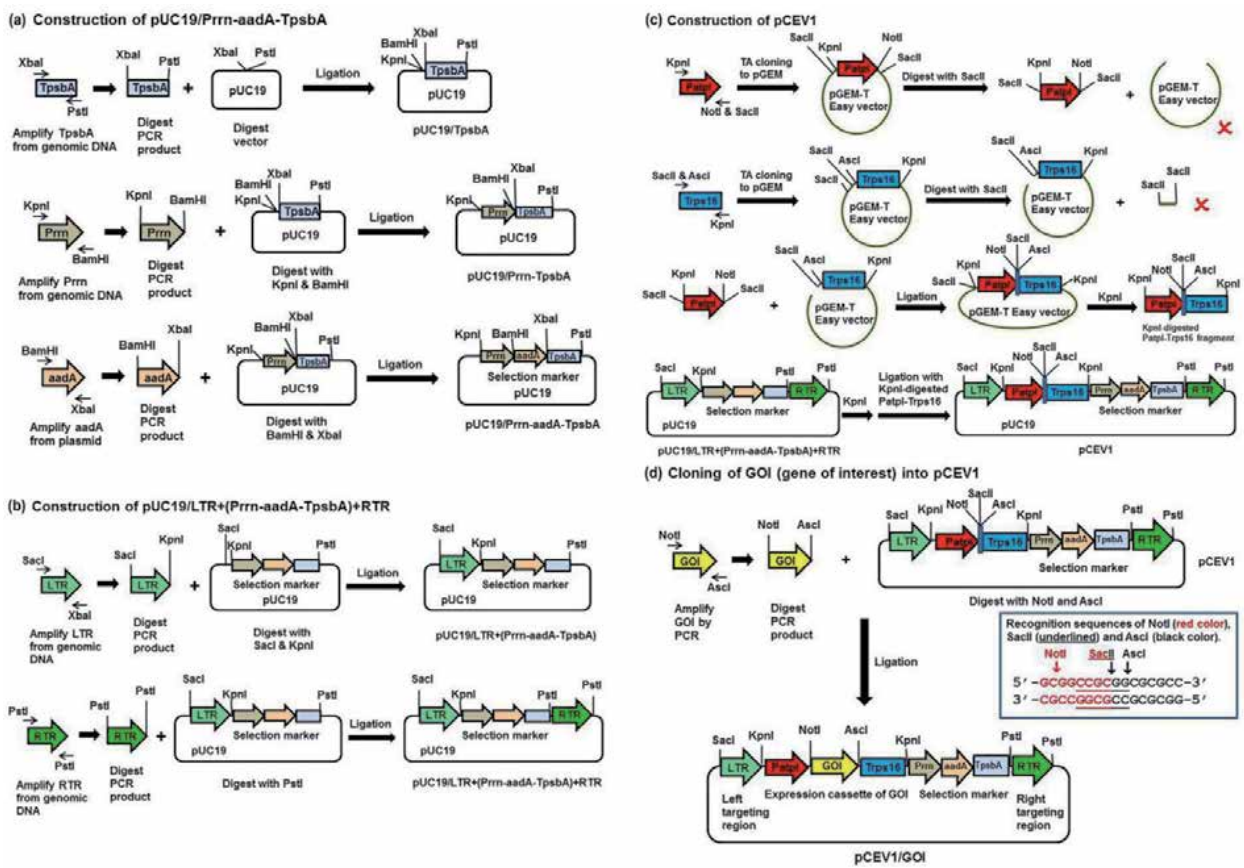

Figure 2.

Step-by-step cloning protocol. 
pCR8 (Invitrogen) as DNA template. After PCR amplification, PCR products were purified and cloned into pGEM-T Easy vector. Plasmid carrying BamHIaadA-XbaI was isolated and double digested by Bam HI and $\mathrm{XbaI}$ and then ligated with pUC19/Prrn-TpsbA which was double digested by Bam $\mathrm{HI}$ and XbaI, resulting in pUC19/Prrn-aadA-TpsbA.

\subsubsection{Cloning of spinach left targeting region (LTR; 2019 bp fragment containing partial} $16 S$ rRNA and full-length trnI in spinach chloroplast genome) into pUC19/Prrn$\operatorname{aadA-TpsbA}$

PCR amplification was carried out using 16S/trnI-F (containing the SacI site) and $16 \mathrm{~S} / \mathrm{trnI}-\mathrm{R}$ (containing the kpnI site) as primers and $500 \mathrm{ng}$ of spinach (S. oleracea) genomic DNA as DNA template. After PCR amplification, PCR products were purified and cloned into pGEM-T Easy vector. Plasmid carrying SacI-LTR$K p n \mathrm{I}$ was isolated and double digested by SacI and KpnI and then ligated with pUC19/Prrn-aadA-TpsbA which was double digested by SacI and KpnI, resulting in pUC19/LTR + (Prrn-aadA-TpsbA).

\subsubsection{Cloning of spinach right targeting region ( $R T R$; 2031 bp fragment containing full- length trnA and partial 23S rRNA in spinach)}

PCR amplification was carried out using trnA/23S-F (containing the Pst I site) and trnA/23S-R (containing the PstI site) as primers and $500 \mathrm{ng}$ of spinach genomic DNA as DNA template. After PCR amplification, PCR products were purified and cloned into pGEM-T Easy vector. Plasmid carrying PstI-RTR-PstI was isolated and digested by PstI and then ligated with pUC19/LTR + (Prrn-aadA-TpsbA) which was digested by PstI, resulting in pUC19/LTR + (Prrn-aadA-TpsbA $)+$ RTR.

\subsubsection{Cloning of PatpI-(cloning sites)-Trps16 into pUC19/LTR + (Prrn-aadA- $T p s b A)+R T R$}

a. Preparation of PatpI (248 bp) fragment: PCR amplification was carried out using PatpI-F (containing the KpnI site) and PatpI-R (containing the NotI and SacII sites) as primers and $500 \mathrm{ng}$ tobacco genomic DNA as template. After PCR amplification, PCR products were purified and cloned into pGEM-T Easy vector.

b. Preparation of Trps16 (169 bp) fragment: PCR amplification was carried out using Trps16-F (containing the SacII and AscI sites) and Trps16-R (containing the KpnI site) as primers and 500 ng tobacco genomic DNA as template. After PCR amplification, PCR products were purified and cloned into pGEM-T Easy vector.

c. Preparation of PatpI-(cloning sites)-Trps16 fragment in pGEM-T Easy vector: pGEM-T Easy vector carrying PatpI was digested by SacII, a small $0.3 \mathrm{~kb}$ fragment containing SacII-KpnI-PatpI-NotI-SacII (the 5' SacII-KpnI sequence was derived from multiple cloning sites in pGEM-T Easy vector and bold) and was isolated by gel electrophoresis and purified. Meanwhile, pGEM-T Easy vector carrying Trps16 was digested by SacII, the large fragment containing SacII-AscI-Trps16-KpnI and almost complete pGEM-T Easy vector, was isolated by gel electrophoresis and purified, and then ligated with SacII-KpnI-PatpI-NotI-SacII fragment. As a result, pGEM-T Easy vector 
carrying SacII-KpnI-PatpI-NotI-SacII-AscI-Trps16-KpnI fragment was generated. The cloning site (NotI-SacII-AscI) is $16 \mathrm{bp}$ in length.

d. Cloning of PatpI-Trps16 fragment into pUC19/LTR + (Prrn-aadA-

TpsbA) + RTR: The plasmid pGEM-T Easy vector carrying SacII-KpnI-PatpI-

NotI-SacII-AscI-Trps16-KpnI fragment was digested by KpnI; this PatpI-

Trps16 fragment was isolated and purified and then ligated with pUC19/ LTR + (Prrn-aadA-TpsbA) + RTR which was digested by KpnI. As a result, pUC19 carrying LTR + (PatpI-cloning site-Trps16) + (Prrn-aadA-

TpsbA) + RTR was generated, and this chloroplast expression vector for spinach was designated as pCEV1 (8375 bp; Figure 3a).

\subsection{Cloning of GOI into pCEV1}

PCR amplification was carried out using LCY-F (containing NotI site) and LCY$\mathrm{R}$ (containing $A s c \mathrm{I}$ site) as primers and $500 \mathrm{ng}$ plasmid DNA of our tomato cDNA clone encoding lycopene $\beta$-cylase (LCY, 1503 bp; Accession no. EF650013) as DNA template. After PCR amplification, PCR products were purified and cloned into pGEM-T Easy vector. Plasmid carrying NotI-LCY-AscI was isolated and double digested by NotI and $A s c \mathrm{I}$ and then ligated with pCEV1 which was double digested by NotI and $A s c$ I, resulting pCEV1/LCY (9878 bp; Figure 3b). Similarly, PCR amplification was carried out using ZDS-F (containing NotI site) and ZDS-R (containing $A s c \mathrm{I}$ site) as primers and 500 ng plasmid DNA of our tomato cDNA

(a)

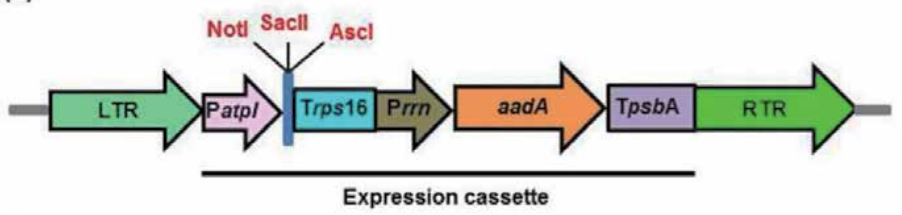

(b)

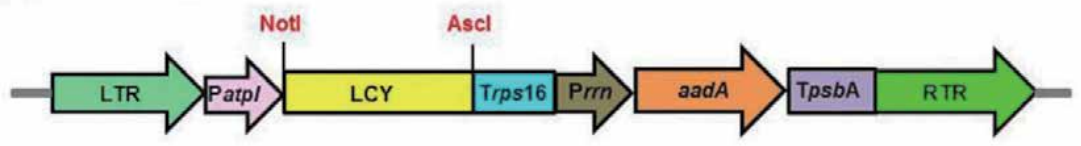

(c)

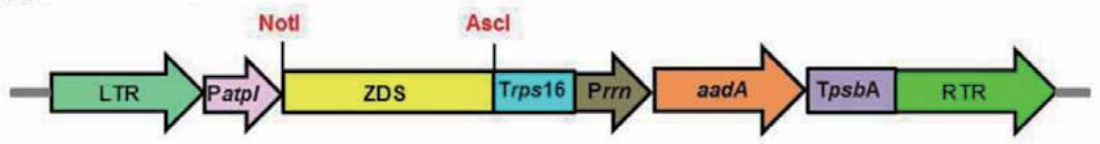

(d)

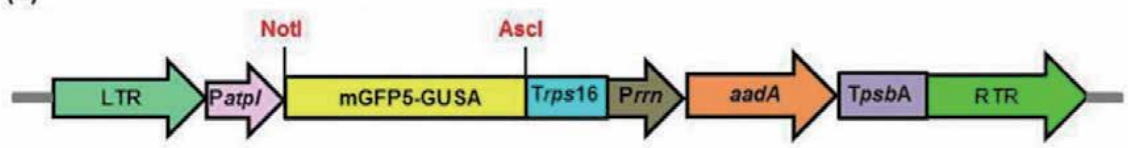

Figure 3.

Chloroplast expression vector $p C E V 1$ and its derivatives specific for spinach. (a) $p C E V 1$. Cloning sites (NotI, SacII, AscI) were inserted between atpI promoter and rps16 terminator. (b) $p C E V 1 / L C Y$. The $c D N A$ fragment (1503 bp) encoding lycopene $\beta$-cyclase (LCY) from tomato was cloned into $p C E V 1$ which was double digested with NotI and AscI, resulting in $p C E V 1 / L C Y$. (c) $p C E V 1 / Z D S$. The cDNA fragment (1767 bp) encoding $\zeta$-carotene desaturase (ZDS) from tomato was cloned into $p C E V 1$ which was double digested with NotI and AscI, resulting in $p C E V 1 / L C Y$. (d) $p C E V_{1} / G F P$-GUS. The DNA fragment (2568 bp) encoding $m G F P_{5}-G U S A$ fusion protein from plasmid $p$ CAMBIA1304 was cloned into $p C E V 1$ which was double digested with NotI and AscI, resulting in $p C E V_{1} / G F P$-GUS. 
clone encoding $\zeta$-carotene desaturase (ZDS, 1767 bp; Accession no. EF650012) as DNA template. After PCR amplification, PCR products were purified and cloned into pGEM-T Easy vector. Plasmid carrying NotI-ZDS-AscI was isolated and double digested by NotI and $A s c \mathrm{I}$ and then ligated with pCEV1 which was double digested by NotI and AscI, resulting in pCEV1/ZDS (10,142 bp; Figure 3c). For cloning the gene (2568 bp) encoding mGFP5-GUSA fusion protein, PCR amplification was carried out using mGPF5-F (containing NotI site) and GUSA-R (containing AscI site) as primers and 500 ng plasmid DNA of pCAMBIA1304 (Center for the Application of Molecular Biology to International Agriculture, Australia) as DNA template. After PCR amplification, PCR products were purified and cloned into pGEMT Easy vector. Plasmid carrying NotI-GFP-GUS-AscI was isolated and double digested by NotI and $A s c \mathrm{I}$ and then ligated with pCEV1 which was double digested by NotI and AscI, resulting in pCEV1/GFP-GUS (10,943 bp; Figure 3d).

\subsection{Construction of chloroplast expression vectors pCEV2 and pCEV 3 and their derivatives}

\subsubsection{Cloning of expression cassette [(PatpI-Trps16) + (Prrn-aadA-TpsbA)] into pUC19}

PCR amplification was carried out using SacI+PatpI-F (containing the SacI site) and TpsbA+PstII-R (containing the PstII site) as primers and 500 ng pCEV1 plasmid DNA as template. After PCR amplification, PCR products $(1.7 \mathrm{~kb})$ were purified and double digested by SacI and PstII and then ligated with pUC19 (ampicillin resistance marker; 2686 bp) which was doubled digested by SacI and PstII, resulting in pUC19/(PatpI-Trps16) + (Prrn-aadA-TpsbA). As described in pCEV1, cloning sites (NotI, SacII, AscI) for GOI are located between PatpI and Trps16. Thus, the resulting plasmid carrying expression cassette for GOI and aadA selection marker on pUC19 was designated as pECaad (4343 bp).

\subsubsection{Cloning of tomato LTR (containing partial 16S rRNA and full-length trnI; 1994 bp) into pECaad}

PCR amplification was carried out using SacI+16S/trnI-F (containing the SacI site) and Le 16S/trnI+SacI-R (containing the SacI site) as primers and $500 \mathrm{ng}$ tomato (S. lycopersicum var. CL5915) genomic DNA as template. After PCR amplification, PCR products (2 kb) were isolated and cloned into pGEM-T Easy vector. Plasmids carrying SacI-LTR-SacI were isolated and digested by SacI and then ligated with pECaad which was digested by SacI, resulting in pUC19/LTR + (PatpITrps16) + (Prrn-aadA-TpsbA).

\subsubsection{Cloning of tomato RTR (containing full-length trnA and partial 23S rRNA; 2004 bp) into pUC19/LTR + (PatpI-Trps16) $+($ Prrn-aadA-TpsbA)}

PCR amplification was carried out using Le PstI+trnA/23S-F (containing the Pst I site) and trnA/23S+PstI-R (containing the PstI site) as primers and tomato ( $S$. lycopersicum var. CL5915) genomic DNA as template. After PCR amplification, PCR products $(2 \mathrm{~kb})$ were isolated and cloned into pGEM-T Easy vector. Plasmid carrying PstI-LTR-PstI was isolated and digested by PstI and then ligated with pUC19/ LTR + (PatpI-Trps16) + (Prrn-aadA-TpsbA) which was digested by PstI. As a result, pUC19 carrying LTR + (PatpI-Trps16) + (Prrn-aadA-TpsbA $)+$ RTR was generated, and this chloroplast expression vector for tomato was designated as pCEV2 (8353 bp). 


\subsubsection{Cloning of GOI into pCEV2}

As described in pCEV1, for cloning the gene (2568 bp) encoding GFP:GUS fusion protein, PCR amplification was carried out using mGPF5-F (containing NotI site) and GUSA-R (containing AscI site) as primers and 500 ng plasmid DNA of pCAMBIA1304 as DNA template. After PCR amplification, PCR products were purified and cloned into pGEM-T Easy vector. Plasmid carrying NotI-GFP-GUS-AscI was isolated and double digested by NotI and $A s c \mathrm{I}$ and then ligated with pCEV2 which was double digested by NotI and AscI, resulting in pCEV2/GFP-GUS (10,921 bp).

\subsubsection{Construction of $p C E V 3$ and $p C E V 3 / G F P-G U S$}

To clone the nptII gene (795 bp), PCR amplification was carried out using $\mathrm{BamHI}+\mathrm{NPTII}-\mathrm{F}$ (containing Bam HI site) and XbaI+NPTII-R (containing XbaI site) as primers and $500 \mathrm{ng}$ pBI121 (GenBank Accession no. AF485783; [27]) plasmid DNA as template. After PCR amplification, PCR products $(0.8 \mathrm{~kb})$ were purified and double digested by Bam HI and XbaI and then ligated with pECaad [i.e., pUC19/ (PatpI-Trps16) + (Prrn-aadA-TpsbA)] which was double digested by BamHI and $X b a I$. Thus, the BamHI-aadA-XbaI fragment was replaced by the BamHI-nptII-XbaI fragment. As a result, pUC19/(PatpI-Trps16) + (Prrn-nptII-TpsbA) was generated and designated as pECnpt (4346 bp). Again, as described in pCEV1, cloning sites (NotI, SacII, AscI) for GOI are located between PatpI and Trps16. The rest of the protocol for cloning tomato LTR and RTR sequences was the same as described for pCEV2. Finally, the new chloroplast expression vector, carrying nptII gene as selection marker for kanamycin resistance, for tomato was designated as pCEV3 (8356 bp). Using the same strategy, the gene encoding mGFP5-GUSA fusion protein was inserted into pCEV3, resulting in pCEV3/GFP-GUS (10,924 bp).

\subsection{Construction of chloroplast expression vector pCEV4 and its derivatives}

Similar to pCEV2, N. benthamiana (Accession no. FJ217346) LTR (containing partial 16S rRNA and full-length trnI; $1995 \mathrm{bp}$ ) was first cloned into pECaad [i.e., pUC19/(PatpI-Trps16) + (Prrn-aadA-TpsbA)] as follows: PCR amplification was carried out using Nb-SacI+16S/trnI-F (containing the SacI site) and Nb-16S/trnI +SacI-R (containing the SacI site) as primers and $500 \mathrm{ng} N$. benthamiana genomic DNA as template. After PCR amplification, PCR products $(2 \mathrm{~kb})$ were isolated and cloned into pGEM-T Easy vector. Plasmid carrying SacI-LTR-SacI was isolated and digested by SacI and then ligated with $\mathrm{pECaad}$ which was digested by SacI, resulting in pUC19/LTR + (PatpI-Trps16) + (Prrn-aadA-TpsbA). Then, cloning of $N$.

benthamiana RTR (containing full-length $\operatorname{trn} A$ and partial $23 S r R N A ; 1908 \mathrm{bp}$ ) into the above plasmid pUC19/LTR + (PatpI-Trps16) + (Prrn-aadA-TpsbA) was described as follows: PCR amplification was carried out using Nb-PstI+trnA/23S-F (containing the PstI site) and Nb-trnA/23S + PstI-R (containing the PstI site) as primers and $500 \mathrm{ng} N$. benthamiana genomic DNA as template. After PCR amplification, PCR products $(1.9 \mathrm{~kb})$ were isolated and cloned into pGEM-T Easy vector. Plasmid carrying PstI-RTR-PstI was isolated and digested by PstI and then ligated with pUC19/LTR + (PatpI-Trps16) + (Prrn-aadA-TpsbA) which was digested by PstI. As a result, pUC19 carrying LTR + (PatpI-Trps16) + (Prrn-aadA-TpsbA) + RTR was generated, and this chloroplast expression vector for $N$. benthamiana was designated as pCEV4 (8246 bp).

For cloning of GOI into pCEV4, PCR amplification was carried out using NotIBaMV_S-F (containing the NotI site) and BaMV_S_CP-AscI-R (containing the AscI site) as primers and $500 \mathrm{ng}$ plasmid pBS2-8 DNA carrying bamboo mosaic virus 
strain S complete genome (6366 bp; GenBank Accession number AF018156) as DNA template. After PCR amplification, PCR products (753 bp containing enzyme cutting sites) for coding region of CP20 were purified and cloned into pGEM-T Easy vector. Plasmid carrying NotI-BaMV_S_CP-AscI was isolated and double digested by NotI and $A s c \mathrm{I}$ and then ligated with pCEV4 which was double digested by $N o t \mathrm{I}$ and $A s c \mathrm{I}$, resulting in pCEV4/BaMV (8975 bp). In addition, PCR amplification was carried out using NotI-BSL6-F (containing the NotI site) and BSL6-AscI-R (containing the $A s c \mathrm{I}$ site) as primers and $500 \mathrm{ng}$ plasmid pBSL6 DNA [carrying $5^{\prime}$ untranslated region (5'-UTR), coding region of CP20, and $3^{\prime}$-UTR] as DNA template. After PCR amplification, PCR products (861 bp containing enzyme cutting sites) of BSL6 (i.e., CP20 containing 5'-UTR and 3'-UTR) were purified and cloned into pGEM-T Easy vector. Plasmid carrying NotI-BSL6-AscI was isolated and double digested by NotI and AscI and then ligated with pCEV4 which was double digested by NotI and AscI, resulting in pCEV4/BSL6 (9083 bp). For cloning the gene encoding mGFP5-GUSA fusion protein, the same strategy was used as for pCEV1. In brief, PCR products of NotI-GFP-GUS-AscI were isolated and double digested by $N o t \mathrm{I}$ and $A s c \mathrm{I}$ and then ligated with pCEV4 which was double digested by NotI and AscI, resulting in pCEV4/GFP-GUS (10,814 bp).

\subsection{Bombardment and transient GUS expression in spinach leaves}

Spinach (S. oleracea cv. Green Giant; Known-You Seed Company, Taiwan) young leaves were excised from in vitro-grown plantlets and inoculated on culture medium [MS salts and vitamins (Duchefa Biochemie B.V., The Netherlands); 3\% sucrose; $0.4 \mathrm{mg} \mathrm{l}^{-1} \mathrm{NAA} ; 1.0 \mathrm{mg} \mathrm{l}^{-1} \mathrm{BA} ; 1.0 \mathrm{mg} \mathrm{l}^{-1} \mathrm{GA}_{3}$; 0.8\% Bacto agar, $\mathrm{pH}$ 5.8] in the dark for 3 days. Then, leaves were bombarded by the biolistic bombardment device (PDS-1000/He Particle Delivery System, Bio-Rad) with $1.25 \mathrm{mg}$ of $0.6 \mu \mathrm{m}$ gold particles (Bio-Rad) coated with $5 \mu \mathrm{g}$ of plasmid DNA (pCEV1/GFP-GUS or pCAMBIA1305.1) using 1100 psi rupture disks (Bio-Rad). The distance from the uncovered Petri dish containing the leaf sample to the top of the PDS chamber was set to $9 \mathrm{~cm}$, and the vacuum was set to $27 \mathrm{~mm} \mathrm{Hg}$. After bombardment, the samples were kept in the dark for 1 day.

GUS activity in bombarded leaves was determined according to the histochemical procedure [28]. Briefly, spinach leaves were stained in staining buffer [100 mM phosphate buffer; $\mathrm{pH} 7.0 ; 0.5 \mathrm{mM}$ ferrocyanide; $0.5 \mathrm{mM}$ ferricyanide; $10 \mathrm{mM}$ EDTA, pH 8.0; 0.1\% Triton X-100; 1 mM Gluc (5-bromo-4-chloro-3-indolyl- $\beta$-Dglucuronic acid, USB)] and incubated overnight at $37^{\circ} \mathrm{C}$. Chlorophylls from leaf tissue were removed by soaking in $70 \%$ ethanol several times.

\subsection{Plastid transformation in spinach and tomato}

Leaf segments were cut from in vitro-grown plantlets of spinach and inoculated on SO culture medium (MS salts and vitamins; $3 \%$ sucrose; $0.5 \mathrm{mg} \mathrm{l}^{-1} 2,4-\mathrm{D}$; $2 \mathrm{mg} \mathrm{l}^{-1}$ kinetin; $0.8 \%$ Bacto agar; pH 5.8) for 1 day in a growth chamber with a cycle of $8 \mathrm{~h} \mathrm{light}$ at $22^{\circ} \mathrm{C}$ and $16 \mathrm{~h}$ dark at $20^{\circ} \mathrm{C}$. Conditions for bombardment were as described above, except that plasmid pCEV1/GFP-GUS, pCEV1/LCY, or pCEV1/ ZDS was used in each individual experiment. After bombardment, the sample was cultured in the dark for 4 days. Then, the bombarded leaf segments were trimmed into small pieces of 2-4 $\mathrm{mm}^{2}$, transferred onto SO selection medium (SO culture medium supplemented with $300 \mathrm{mg} \mathrm{l}^{-1}$ spectinomycin), and cultured for 1 month in a growth chamber with a cycle of $8 \mathrm{~h}$ light at $22^{\circ} \mathrm{C}$ and $16 \mathrm{~h}$ dark at $20^{\circ} \mathrm{C}$. Survival green calli were picked up and transferred onto fresh $\mathrm{SO}$ selection medium and cultured for another 1 month in the same growth chamber. 
For plastid transformation in tomato, leaf segments were cut from plantlets of tomato (S. lycopersicum cv. CL5915) grown in vitro and inoculated on SL culture medium (MS salts and vitamins; 3\% sucrose; $0.2 \mathrm{mg} \mathrm{l}^{-1} 2,4-\mathrm{D} ; 0.1 \mathrm{mg} \mathrm{l}^{-1}$ kinetin; $0.8 \%$ Bacto agar; $\mathrm{pH}$ 5.8) for 1 day in a growth chamber with a cycle of $8 \mathrm{~h}$ light at $22^{\circ} \mathrm{C}$ and $16 \mathrm{~h}$ dark at $20^{\circ} \mathrm{C}$. Conditions for bombardment were as described above, except that plasmid pCEV2/GFP-GUS or pCEV3/GFP-GUS was used in each individual experiment. After bombardment, the sample was cultured in the dark for 3 days. Then, the bombarded leaf segments were trimmed into small pieces of $2-$ $4 \mathrm{~mm}^{2}$, transferred onto SL selection medium (MS salts and vitamins; $3 \%$ sucrose; $1 \mathrm{mg} \mathrm{l}^{-1} \mathrm{NAA} ; \mathrm{mg} \mathrm{l}^{-1}$ zeatin; 0.8\% Bacto agar; $\mathrm{pH}$ 5.8), and supplemented with $300 \mathrm{mg} \mathrm{l}^{-1}$ spectinomycin (for pCEV2/GFP-GUS) or $50 \mathrm{mg} \mathrm{l}^{-1}$ kanamycin (for pCEV3/GFP-GUS) for 1 month in the same growth chamber. Survival green calli were picked up and transferred on fresh selection medium for another 1 month.

\subsection{Plastid transformation and selection of transplastomic lines in $N$. benthamiana}

Leaf segments were cut from in vitro-grown plantlets of $N$. benthamiana and inoculated on NB culture medium (MS salts and vitamins; $3 \%$ sucrose; $0.1 \mathrm{mg} \mathrm{l}^{-1}$ NAA; $1.0 \mathrm{mg} \mathrm{l}^{-1} \mathrm{BA}$; 0.8\% Bacto agar; $\mathrm{pH}$ 5.8) for 1 day in a growth chamber with a cycle of $8 \mathrm{~h}$ light at $22^{\circ} \mathrm{C}$ and $16 \mathrm{~h}$ dark at $20^{\circ} \mathrm{C}$. Conditions for bombardment were previously described, except that plasmid pCEV4/BaMV or pCEV4/BSL6 was used in each individual experiment. After bombardment, the sample was cultured in the dark for 3 days. Then, the bombarded leaf segments were trimmed into small pieces of $2-4 \mathrm{~mm}^{2}$, transferred onto NB selection medium (NB culture medium supplemented with $300 \mathrm{mg} \mathrm{l}^{-1}$ spectinomycin), and cultured for 1 month in a growth chamber with a cycle of $8 \mathrm{~h} \mathrm{light}$ at $22^{\circ} \mathrm{C}$ and $16 \mathrm{~h}$ dark at $20^{\circ} \mathrm{C}$. Survival green shoots were excised and transferred onto MS basal medium for rooting. The rooted plantlets were transferred into pots and grown in a greenhouse.

\subsection{Transplastomic plant verification by PCR analysis}

Transplastomic plant verification was carried out with putative transformants and wild-type $N$. benthamiana plants by PCR analysis. Total genomic DNA was extracted from green leaves of putative transformants and wild-type plants using the CTAB method [26]. PCR was carried out with the following sets of primers (Table A1): BSL-F and BSL-R for amplification of 837-bp-long DNA fragment corresponding to the $5^{\prime}$ UTR coding region and $3^{\prime}$ UTR of coat protein (CP20) in BaMV strain S (GenBank Accession no. AF018156), BaMV-F and BaMV-R for amplification of 729-bp-long DNA fragment corresponding to the coding region of CP20 in BaMV strain S, TpsbA-F and trnI-trnA-r for amplification of 351-bp-long DNA fragment corresponding to the truncated sequence composed of the transgenic TpsbA and partial RTR of $N$. benthamiana chloroplast genome, and trnA-f and 23S-rRNA-r for amplification of 342-bp-long DNA fragment located within the RTR of $N$. benthamiana chloroplast genome. PCR reactions were performed under the following conditions: (a) denaturation for $5 \mathrm{~min}$ at $94^{\circ} \mathrm{C}$; (b) 35 cycles of $1 \mathrm{~min}$ at $94^{\circ} \mathrm{C}, 1 \mathrm{~min}$ at $55^{\circ} \mathrm{C}$, and $1 \mathrm{~min}$ at $72^{\circ} \mathrm{C}$; and (c) extension for $10 \mathrm{~min}$ at $72^{\circ} \mathrm{C}$. Following amplification, PCR products were analyzed by electrophoresis.

\subsection{Seedling assay for spectinomycin resistance}

$\mathrm{T}_{1}$ seeds from a self-pollinated transplastomic plant were sterilized in $70 \%$ ethanol for $0.5 \mathrm{~min}$ followed by $1 \%$ sodium hypochlorite for $10 \mathrm{~min}$ and washed 
thoroughly with sterile distilled water. The sterile seeds were germinated on a medium containing MS basal medium supplemented with $300 \mathrm{mg} \mathrm{l}^{-1}$ spectinomycin in a $25^{\circ} \mathrm{C}$ growth chamber under $16 \mathrm{~h}$ illumination for 4 weeks. Seedlings with green cotyledons were considered to be resistant, while those with white cotyledons were sensitive.

\subsection{GenBank accession numbers}

Nucleotide sequences in this study were submitted into GenBank with the following accession numbers: pCEV1, KY930497; pCEV2, KY930498; pCEV3, KY930499; pCEV4, KY930500; pECaad, KY930501; pECnpt, KY930502; Nicotiana benthamiana chloroplast DNA fragment containing partial $16 S r R N A, \operatorname{trnI}, \operatorname{trn} A$, and partial $23 S$ rRNA, KY930503.

\section{Results and discussion}

\subsection{Construction of spinach chloroplast expression vectors}

Although the complete chloroplast genome of spinach has been published [22], plastid transformation in spinach has not yet been reported. As a first step in achieving plastid transformation in spinach, spinach-specific chloroplast expression vectors must be constructed. As shown in Figure 1, the integration site for the expression cassette is designed at the spacer region between $t r n I$ and $t r n A$. This integration site at $\operatorname{trnI} / \operatorname{trn} A$ has been commonly used in constructing chloroplast expression vectors in different plants [1]. In addition, the trnI gene contains the chloroplast replication origin which might promote replication of foreign vectors within chloroplasts and enhance the transgene integration [1, 29]. Another feature of our chloroplast expression vectors is the use of longer sequences for targeting via homologous recombination: the left targeting region (ca. $2 \mathrm{~kb}$ ) contains partial $16 \mathrm{~S}$ $r R N A$ and full-length $t r n I$, whereas the right targeting region (ca. $2 \mathrm{~kb}$ ) contains full-length $\operatorname{trn} A$ and partial $23 S r R N A$ (Figure 1). Targeting sequences are usually $1 \mathrm{~kb}$ each in size and are located on both sides of the expression cassette [1]. However, a $4 \mathrm{~kb}$ DNA fragment containing $16 S \mathrm{rRNA}$-trnI/trnA-23S $r R N A$ (i.e., $2 \mathrm{~kb}$ each on either side of the expression cassette), which is twice the size of the flanking region commonly used in chloroplast transformation, was used in cotton chloroplast transformation [9]. It has been reported that the frequency of homologous recombination is linearly reliant on the length of the homologous sequences [30]. Thus, in this study, each of the left/right targeting sequences was increased to $2 \mathrm{~kb}$ (total $4 \mathrm{~kb}$ in length), similar in size to that described in cotton chloroplast transformation [9].

Next, each DNA fragment including the left and right targeting regions, synthetic unique cloning sites (NotI, SacII, AscI) flanked by atpI promoter and rps 16 terminator, as well as aadA selection marker gene flanked by $r m$ promoter and $p s b A$ terminator (Figure 1) were amplified by PCR and cloned and inserted into pUC19 according to a step-by-step protocol (Figure 2), and finally a chloroplast expression vector for spinach (designated as pCEV1) was constructed (Figure 3a). Any GOI may be cloned into pCEV1 by using the restriction enzyme NotI, SacII, or AscI. However in this study, pCEV1 was double digested by NotI and $A s c \mathrm{I}$ and ligated with a PCR fragment of the GOI carrying NotI or AscI restriction site at each end. As a result, pCEV1/LCY [carrying full-length cDNA (1503 bp) encoding LCY from tomato], pCEV1/ZDS [carrying full-length cDNA (1767 bp) encoding ZDS from tomato], and pCEV1/GFP-GUS [carrying mGFP5-GUSA fusion protein gene 
(2568 bp) from pCAMBIA1304] were constructed (Figure 3). To check the accuracy of the cloning sites, plasmid DNA was isolated from E. coli carrying PCEV1, pCEV1/ZDS, pCEV1/LCY, or pCEV1/GFP-GUS and double digested with NotI and AscI. As shown in Figure 4, only a large fragment (it should be $8367 \mathrm{bp}$ ) was detected in pCEV1 after double digestion was carried out; the small fragment (it should be $8 \mathrm{bp}$ ) was not observed. As predicted, the same size large fragment (it should be $8367 \mathrm{bp}$ ) was detected in pCEV1/ZDS, pCEV1/LCY, or pCEV1/GFP-GUS; however, different sizes of small fragment including coding regions of LCY (1503 bp), ZDS (1767 bp), and GFP-GUS (2568 bp) were easy to detect and match according to the prediction (Figure 4). Thus, we concluded that spinach chloroplast expression vector pCEV1 and its derivatives were successfully constructed.

\subsection{Transient GUS expression and development of plastid transformation in spinach}

To evaluate the functionality of the constructed vector, spinach chloroplast expression vector pCEV1/GFP-GUS [carrying a mGFP5-GUSA fusion protein gene driven by plastid atpI promoter (PatpI) from tobacco] (Figure 3d) or positive nuclear control pCAMBIA1305.1 [carrying GUSPlus driven by cauliflower mosaic virus (CaMV) 35S promoter] was used to independently bombard the spinach leaves followed by GUS staining. As shown in Figure 5d, no blue spots were detected in leaf samples without bombardment (negative control). Only one to two

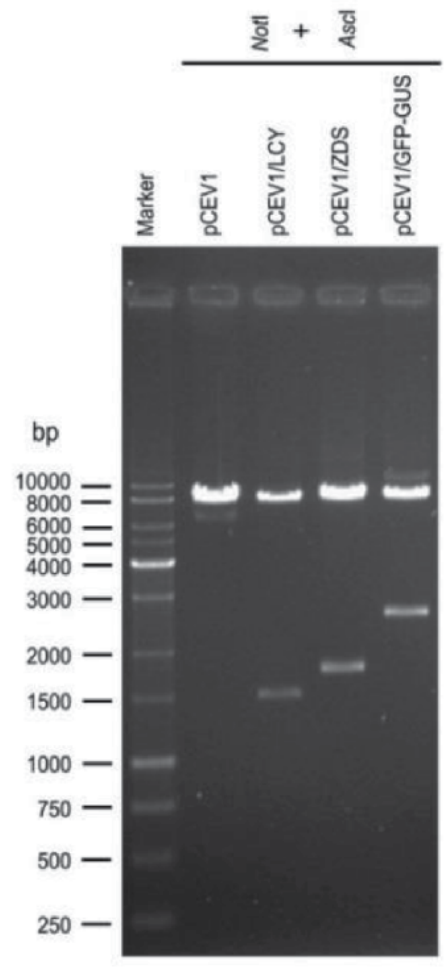

Figure 4.

Restriction endonuclease analysis for the cloning sites in $p C E V_{1}$ and its derivatives. Three milligrams of vector $D N A$ was double digested with $\operatorname{Not} I(10 U)$ and $\operatorname{AscI}(10 \mathrm{U})$ for $2 \mathrm{~h}$ at $37^{\circ} \mathrm{C}$, and then the restriction fragments were separated by $0.8 \%$ agarose gel electrophoresis in TAE buffer. After digestion, the expected fragments (in bp) for each vector were as follows: $p C E V_{1}, 8367$ and $8 ; p C E V 1 / L C Y, 8367$ and 1511; $p C E V_{1} /$ ZDS, 8367 and 1775; and $p C E V 1 / G F P-G U S, 8367$ and 2576. The observed fragments in each digested vector were the same sizes as predicted. 
very small blue spots per leaf were detected in leaves bombarded with pCEV1/GFPGUS (Figure 5a and $\mathbf{b}$ ). This is because to display blue spots, the golden particles carrying pCEV1/GFP-GUS need to pass through the cell wall and then the cell membrane and then the chloroplast membrane into the chloroplast of a cell, for which the probability is small, so the tiny but condensed blue spots indicated that GUS expression was indeed detected within chloroplasts. On the other hand, more than 10 blue spots per leaf were detected when bombardment was carried out with pCAMBIA1305.1, and the sizes of the blue spots were much larger than those blue spots bombarded with pCEV1/GFP-GUS (Figure 5c). It is worth pointing out that pCAMBIA1305.1 is a cloning vector for stable plant transformation. Just like other pCAMBIA vectors, the T-DNA region (containing selection marker nptII gene, expression cassette for GOI and reporter gene GUSPlus) in pCAMBIA1305.1 will integrate into the plant nuclear genome via a stable transformation process. However in the bombardment experiment followed by transient GUS staining assay, cytosolic GUS activity can also be detected when plant tissue is bombarded with pCAMBIA series (such as pCAMBIA1305.1), since the gus gene in the transformation vector is driven by non-tissue specific and constitutive CaMV $35 \mathrm{~S}$ promoter. Particularly, CAMBIA's GUSPlus is a patented reporter gene isolated from Staphylococcus species with some properties that are superior to the conventional E. coli gus A gene (http://www.cambia.org). Previously, Ye et al. [31] reported that a chloroplast expression vector pHD203-GUS [carrying gus and chloramphenicol acetyltransferase (cat) genes driven by a double chloroplast $p s b$ promoter fragment from pea (in opposite orientation)] and a positive nuclear control pBI505 (carrying a gus gene driven by a double CaMV 35S promoter plus a leader sequence
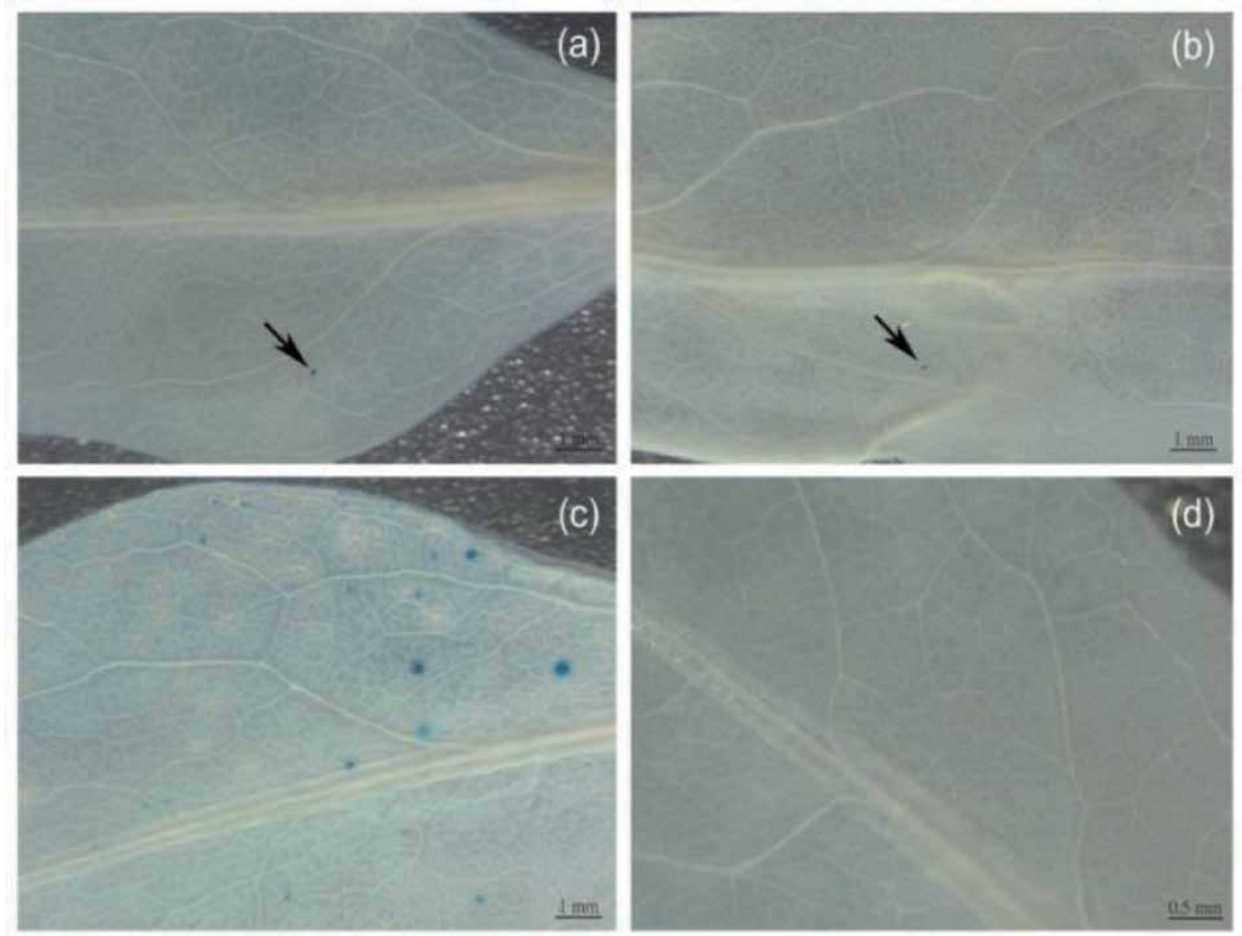

Figure 5.

Transient GUS expression. Spinach leaves were bombarded with golden particles coated with equal amounts $(5 \mathrm{mg})$ of plastid vector $p C E V_{1} / G F P-G U S(a, b)$ or nuclear vector $p C A M B I A 1305.1$ (c). After

bombardment, samples were kept in the dark for 1 day, and then GUS staining was carried out. Spinach leaf without bombardment was used as a negative control $(d)$. 
from alfalfa mosaic virus) were separately bombarded into tobacco suspension cells, followed by GUS staining, and examined by microscopy. Cells bombarded with pBI505 showed high levels of GUS expression, as indicated by blue spots, and were distributed evenly throughout the cytosol of the transformed cells, whereas pHD203-GUS was expressed in chloroplasts. Chloroplast transient expression rates appeared to be 40-50-fold or even 300-400-fold lower than nuclear transformation rates [31]. Later, the same chloroplast expression vector pHD203-GUS together with positive (pBI221) and negative (pUC18) controls was used to develop an electroporation-mediated method for the study of foreign gene expression within spinach chloroplasts, and this study found that both GUS and CAT activities were detected in chloroplasts electroporated with pHD203-GUS but not with both controls; the expression of GUS protein in pHD203-GUS-treated chloroplasts was further confirmed by Western blot analysis [32]. Taken together, our observation in transient GUS expression is consistent with what was previously described under microscopy [31] and confirms that pCEV1/GFP-GUS is a functional vector.

Next, leaves from in vitro-grown plantlets of spinach (S. oleracea cv. Green Giant) were excised and bombarded with pCEV1/LCY, pCEV1/ZDS, and pCEV1/GFP-GUS individually. Almost all leaf segments became larger but turned brown in color after incubation for 1 month in selective medium, suggesting that the screening medium is effective (Figure A1b). Eventually, a few green calli were identified (small panel in Figure A1b) from hundreds of explants after bombardment. Currently, plant regeneration from spectinomycin-resistant calli is in progress.

\subsection{Construction of chloroplast expression vectors for tomato and N. benthamiana}

In order to rapidly construct other chloroplast expression vectors for other plant species (i.e., tomato and N. benthamiana), a DNA fragment (1667 bp) containing expression cassettes of atpI promoter and cloning sites for GOI and rps 16 terminator, followed by selection marker aadA gene, was amplified by a PCR strategy using a pCEV1 as a DNA template. After double digestion with SacI and PstI, the PCR product was ligated with pUC19 which was double digested with SacI and PstI, resulting in a new auxiliary vector pECaad (Figure 6a). Accuracy of the inserted DNA fragment has been confirmed by DNA sequencing. Thus, tomato LTR

(a) pECaad (4343 bp)

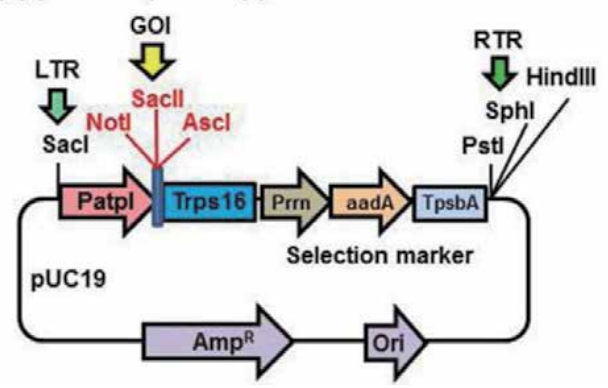

(b) pECnpt (4346 bp)

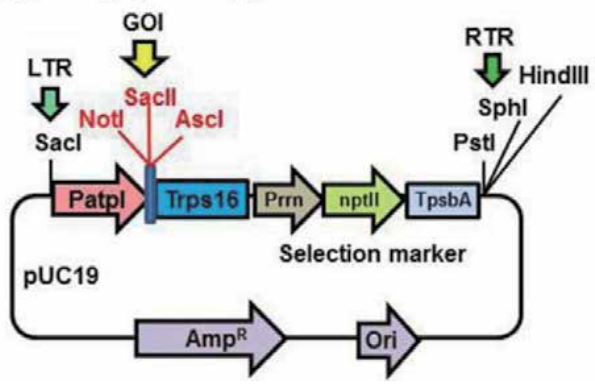

Figure 6.

Schematic representation of the auxiliary vectors $p E C a a d(a)$ and $p E C n p t(b)$. Selection marker aminoglycoside $3^{\prime}$-adenyltransferase ( $\operatorname{aadA} ; 792 \mathrm{bp}$ ) was used in pECaad (a), and selection marker neomycin phosphotransferase (nptII; $795 \mathrm{bp}$ ) conferring kanamycin resistance was used in $p E C n p t(b)$. Besides the selection marker genes, the other sequences in both vectors were the same. The left targeting region (LTR) from the plastid genome of plant species can be inserted into these vectors at the SacI site, while the right targeting region $(R T R)$ can be inserted at $\mathrm{Pst} I, \mathrm{Sph} I$, or HindIII site which is a partial sequence of multiple cloning sites from pUC19. Gene of interest (GOI) can be cloned into these vectors by using our cloning sites (NotI, SacII, AscI). 
(containing partial 16S rRNA and trnI) can be inserted into the SacI site of the $5^{\prime}$ terminus by using forward primer SacI $+16 \mathrm{~S} /$ trnI-F and reverse primer Le-16S/trnI +SacI-R and tomato DNA as a DNA template for PCR amplification; and tomato RTR (containing $\operatorname{trn} A$ and partial $23 S r R N A$ ) can be inserted into the Pst I site of the $3^{\prime}$ terminus by using forward primer Le-PstI+trnA/23S-F and reverse primer $\operatorname{trn} \mathrm{A} /$ 23S+PstI-R and tomato DNA as a DNA template for PCR amplification. As a result, chloroplast expression vector pCEV2 for tomato was constructed (Figure A2). To clone the GOI into pCEV2, the PCR fragment, carrying GFP:GUS fusion protein gene with NotI at one end and AscI at the other end, was inserted into pCEV2 which was double digested with $N o t \mathrm{I}$ and $A s c \mathrm{I}$, resulting in pCEV2/GFP-GUS (Figure A2).

Complete plastid genome sequences have been reported for tobacco $(N$. tabacum; NC_001879), spinach (S. oleracea; NC_002202), and tomato (S. lycopersicum; NC_007898) but not for N. benthamiana. However, partial chloroplast sequence of $N$. benthamiana $16 \mathrm{~S}-23 \mathrm{~S}$ ribosomal RNA intergenic spacer including $\operatorname{trnI}$ and $\operatorname{trn} A$ genes has been determined (1874 bp; FJ217346). In order to prepare a longer targeting sequence (ca. $4 \mathrm{~kb}$ in total) in $N$. benthamiana, forward and reverse primers were designed within $16 S r R N A$ and $23 S r R N A$, respectively, according to the plastid genome of $N$. tabacum, and total genomic DNA from $N$. benthamiana was used as a DNA template for PCR amplification. The PCR product was cloned and then sequenced. As expected, a longer targeting sequence (3893 bp) containing partial $16 S$ rRNA, trnI, trnA, and partial $23 S$ rRNA in N. benthamiana was obtained. As shown in Figure A3, 9 bp (GTTCGGCCT) insertion was conducted in $N$. benthamiana as compared to $N$. tabacum plastid genome. The same $9 \mathrm{bp}$ insertion, located in the intron of trnI in $N$. benthamiana, has been reported [33]. In addition, two more nucleotides, indicated by the first and second arrow in Figure A3, were changed between N. tabacum and our N. benthamiana sequence. Moreover, five unknown nucleotides (labeled as "N") in the published N. benthamiana sequence (FJ217346) were determined in our N. benthamiana sequence. These five nucleotides in our N. benthamiana sequence were identical to N. tabacum (Figure A3).

Using the strategy in pCEV2, LTR and RTR from $N$. benthamiana were rapidly amplified by PCR and then inserted into pECaad, resulting in chloroplast expression vector pCEV4 for $N$. benthamiana (Figure A4). Similarly, GOI regarding gfp:gus, coat protein CP20 gene with or without $5^{\prime}$ - and $3^{\prime}$-untranslated region (UTR) from BaMV satellite RNA was cloned separately into pCEV4 which was double digested with NotI and AscI, resulting in pCEV4/GFP-GUS, pCEV4/BSL6 (CP20 containing $5^{\prime}$ - and $3^{\prime}$-UTR) and pCEV4/BaMV (CP20 only), respectively (Figure A4). Therefore, the GOI can be inserted into our chloroplast expression vectors pCEV1, pCEV2, and pCEV4 specific for spinach, tomato, and N. benthamiana, respectively. Moreover, although the $\operatorname{trnI} / \operatorname{trn} A$ fragment (here we used the longer sequence of partial 16S $r R N A$-trnI/trnA-partial 23S $r R N A$ ) is one of the most frequently used targeting region in plastid transformation $[3,5]$, if a researcher wants to use another targeting region, such as $r b c L / a c c D, r p l 32 / t r n L$, petA/psbJ, trnfM/trnG, trnN/trnR, $a t p B / r b c L, r p s 7 / n d h B$, or $y c f 3 / t r n S$ [5], such chloroplast targeting sequence can be amplified and cloned into our auxiliary vector pECaad (Figure 6a) which carries the expression cassette for the GOI and selection marker aadA on pUC19. We believe that our auxiliary vector pECaad will be of benefit for constructing different targeting regions for plastid transformation.

For selection in plastid transformation, aadA gene conferring spectinomycin resistance is widely used and is the most efficient selective marker [2]; however, nptII gene conferring kanamycin resistance has also been developed for tobacco plastid transformation [34]. Thus, besides the selection marker aadA gene which has been used in pCEV1, pCEV2, pCEV4, and their derivatives, we also constructed $n p t I I$ gene as a selection marker for tomato plastid transformation. In brief, PCR- 
amplified BamHI-nptII-XbaI fragment was subcloned and replaced the BamHIaadA-XbaI fragment in $\mathrm{pECaad}$, generating another auxiliary vector $\mathrm{pECnpt}$ (Figure 6b) which carries an expression cassette for GOI and nptII selection marker on pUC19. Then, tomato LTR and RTR were sequentially cloned into pECnpt, generating a new chloroplast expression vector $\mathrm{pCEV} 3$ for tomato plastid transformation by using selection marker $n p t I I$ gene (Figure A2). Similarly in pCEV2, the gene encoding GFP:GUS fusion protein was inserted into pCEV3 with double digestion by NotI and $A s c$ I, resulting in pCEV3/GFP-GUS (Figure A2).

\subsection{Bombardment, selection, and verification of transplastomic $N$. benthamiana lines}

To further evaluate the functional expression of our constructs, plasmids pCEV4/BaMV and pCEV4/BSL6 were bombarded separately into $N$. benthamiana . After bombardment, almost all leaf segments turned brown and finally died in NB selection medium containing $300 \mathrm{mg} \mathrm{l}^{-1}$ spectinomycin for 1-month culture. From a total of 344 leaf segments we used, only 1 shoot was regenerated using pCEV4/ $\mathrm{BaMV}$ as a transforming vector (Figure 7a), and also only 1 shoot was regenerated from a total of 340 leaf segments examined using pCEV4/BSL6 as a transforming vector (Figure 7b). These shoots were cut and transferred into MS basal medium without spectinomycin for rooting. Finally, two putative transplastomic plantlets, one from pCEV4/BaMV and another from pCEV4/BSL6, were obtained and transferred into a greenhouse. Thus, the transformation efficiency for both vectors pCEV4/BaMV and pCEV4/BSL6 was $0.3 \%$.

For the putative transgenic line transformed by pCEV4/BSL6, genomic DNA was isolated from leaves of the putative line and wild-type $N$. benthamiana, and PCR amplification was carried out. A unique band of $837 \mathrm{bp}$, representing CP20 coding region flanked by $5^{\prime}$-UTR and $3^{\prime}$-UTR in the transforming vector pCEV4/BSL6, was detected in samples from the transplastomic line BSL6 as well as the positive control vector pCEV4/BSL6 (Figure 8b). No PCR product was detected in the WT plant (Figure 8b). To demonstrate the quality of DNA we isolated, a primer set amplifying a $342 \mathrm{bp}$ fragment between $\operatorname{trn} A$ and $23 S \mathrm{~S} R N A$ of plastid genome in $N$. benthamiana was
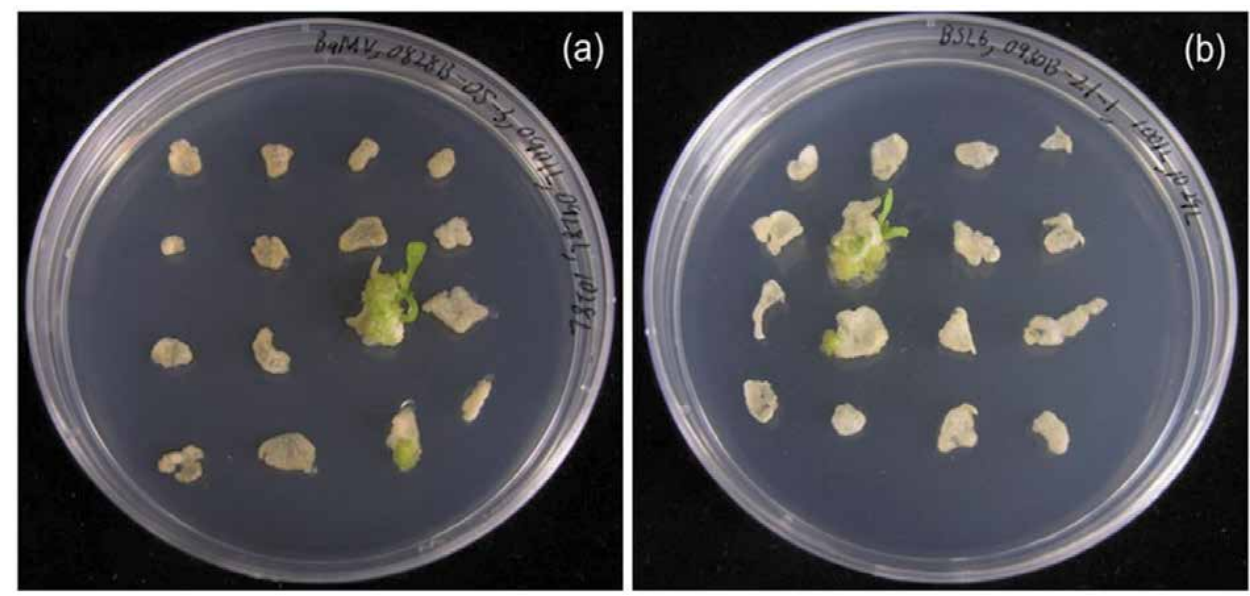

Figure 7.

Selection of transplastomic Nicotiana benthamiana lines. Vector DNA of $p C E V 4 / B a M V($ a $)$ or $p C E V 4 / B S L 6$ (b) was used to bombard leaf segments of $\mathrm{N}$. benthamiana. After bombardment, leaf segments were trimmed into small pieces and transferred onto NB selection medium containing $300 \mathrm{mg} \mathrm{l}^{-1}$ spectinomycin for 1 month. Green shoots from selection medium were cut and transferred onto MS basal medium (without spectinomycin) for rooting. 
designed (Figure 8a). As expected, a unique band (ca. $0.3 \mathrm{~kb}$ ) was detected in our transplastomic plant BSL6, the WT and the positive control vector pCEV4/BSL6 (Figure 8c). To further confirm the integration site in the transplastomic line, forward primer TpsbA-F was designed within the terminator region of $p s b A$ in the vector pCEV4/BSL6, and reverse primer trnA-r was located at the $\operatorname{trn} A$ of the right targeting region in the vector pCEV4/BSL6. As predicted, a unique band of $351 \mathrm{bp}$ was detected in transplastomic plant BSL6 but not in the WT (Figure 8d). In conclusion, the expression cassette carrying CP20 encoding gene (with $5^{\prime}$ - and $3^{\prime}$-UTR) and add selection marker gene flanked by LTR (i.e., Nb 16S rRNA/trnI) and RTR (i.e., Nb trnA/23S) was indeed integrated into the $t r m I / t m A$ integration site by homologous recombination of plastid genome in transplastomic line BSL6. Unfortunately, serious infection by microorganisms occurred in this plant and it finally died.

For the putative transplastomic line which was transformed by $\mathrm{pCEV} 4 / \mathrm{BaMv}$, self-pollinated seeds from the $\mathrm{T}_{0}$ transplastomic line BaMV as well as WT seeds were sterilized and then germinated on MS basal medium supplemented with $300 \mathrm{mg} \mathrm{l}^{-1}$ for 4 weeks. As shown in Figure $\mathbf{9 b}$, all $\mathrm{T}_{1}$ seedlings from the BaMV plant examined were resistant to spectinomycin, confirming an important characteristic of maternal inheritance in plastid transformation. By contrast, all seedlings from the WT were sensitive to spectinomycin (Figure 9a). To further confirm the transgene, three spectinomycin-resistant seedlings were randomly picked up from the selection plate, transferred onto MS basal medium without spectinomycin, and then grown in a greenhouse. Genomic DNA was isolated from these transplastomic $\mathrm{T}_{1}$ as well as WT plants, and PCR analysis was then carried out (Figure 10).
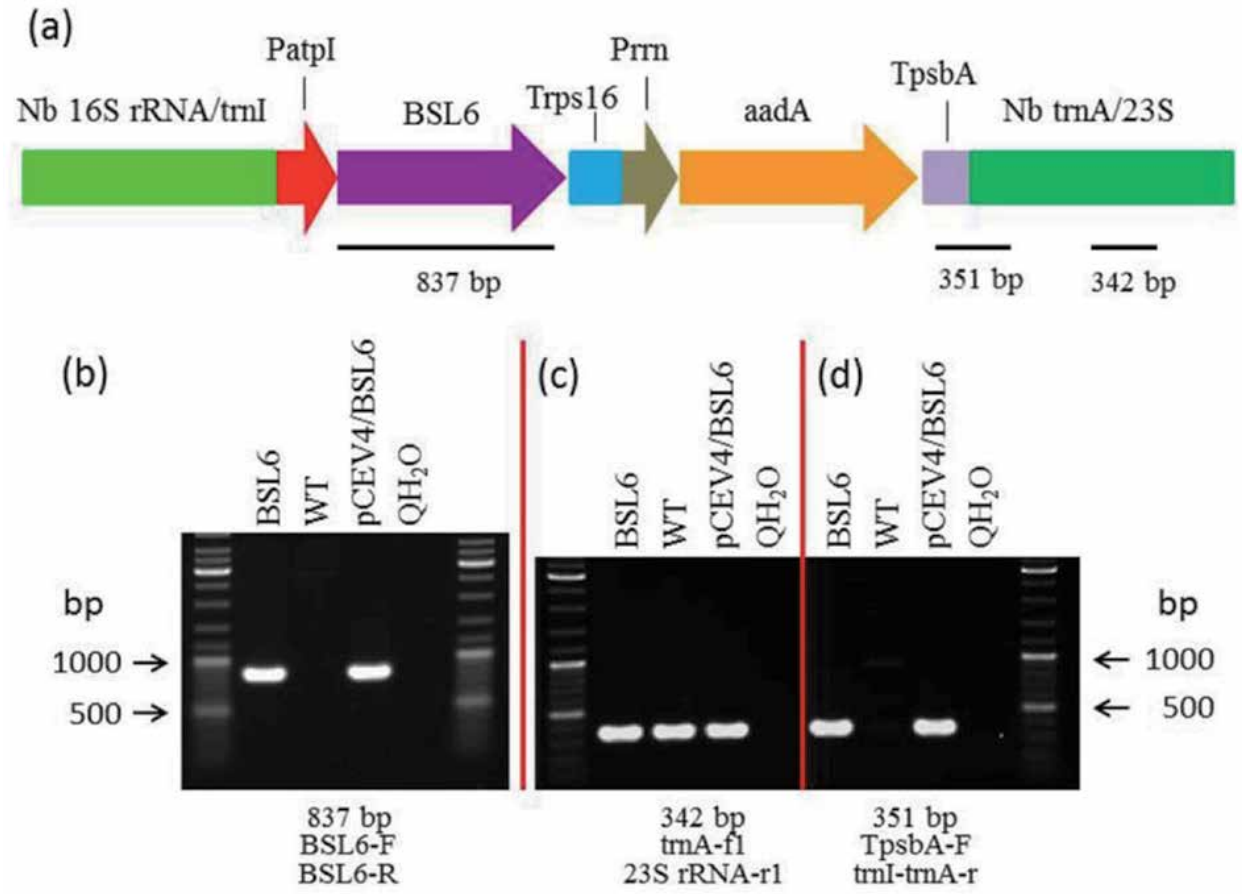

Figure 8.

PCR analysis of $T_{o}$ transplastomic Nicotiana benthamiana plant bombarded by $p C E V 4 / B S L 6$. (a) Schematic representation of $p C E V 4 / B S L 6$. Sizes and locations of gene-specific PCR products were indicated. (b) PCR analysis for transgene BSL6 (837 bp). The PCR product was only detected in the transplastomic line but not in the WT plant. (c) PCR analysis of the internal trnA/23S rRNA region (342 bp). PCR products were detected in both WT and transplastomic lines. (d) PCR analysis for the flanking region (351 bp). The PCR product was only detected in the transplastomic line but not in the WT plant. " $\mathrm{OH}_{2} \mathrm{O}$ " in each panel represented the negative control to which no DNA was added in the reaction mixture for PCR amplification. 

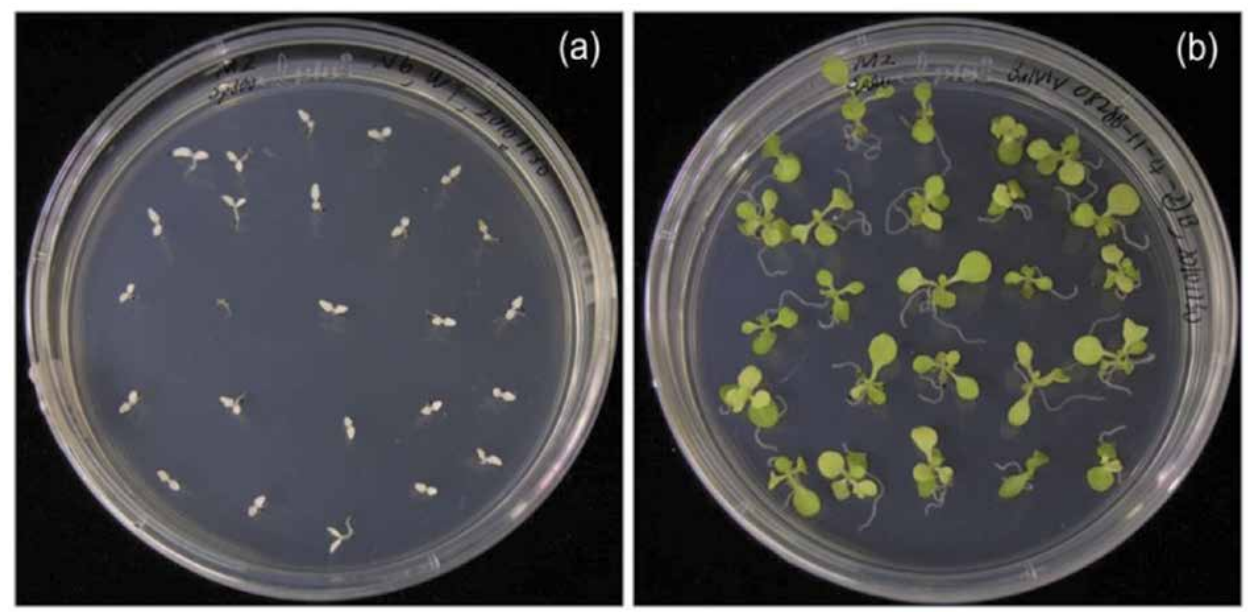

Figure 9.

Seedling assay of $T_{o}$ transplastomic Nicotiana benthamiana plant bombarded by $p C E V 4 / B a M V$. Seeds from the WT (a) and the transplastomic plant (b) were harvested, sterilized, and then sown on MS basal medium containing $300 \mathrm{mg} \mathrm{l}^{-1}$ spectinomycin for 4 weeks. (a) All seedlings from the WT plant showed spectinomycinsensitive phenotype. (b) All seedlings from the transplastomic plant showed spectinomycin-resistant phenotype.

(a)

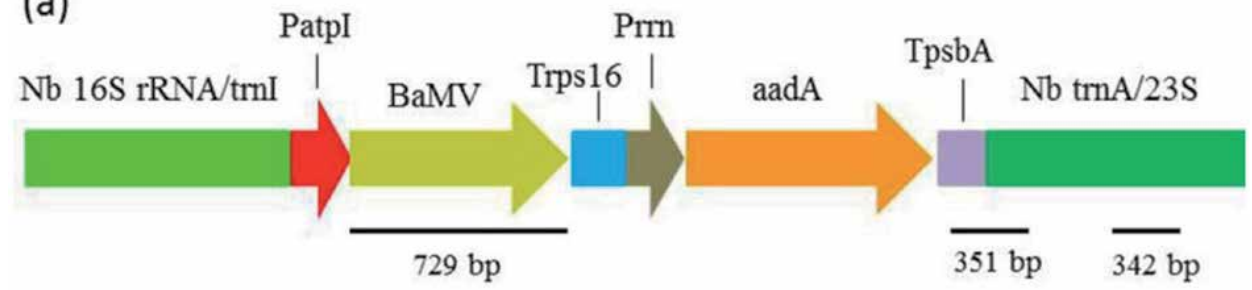

(b)

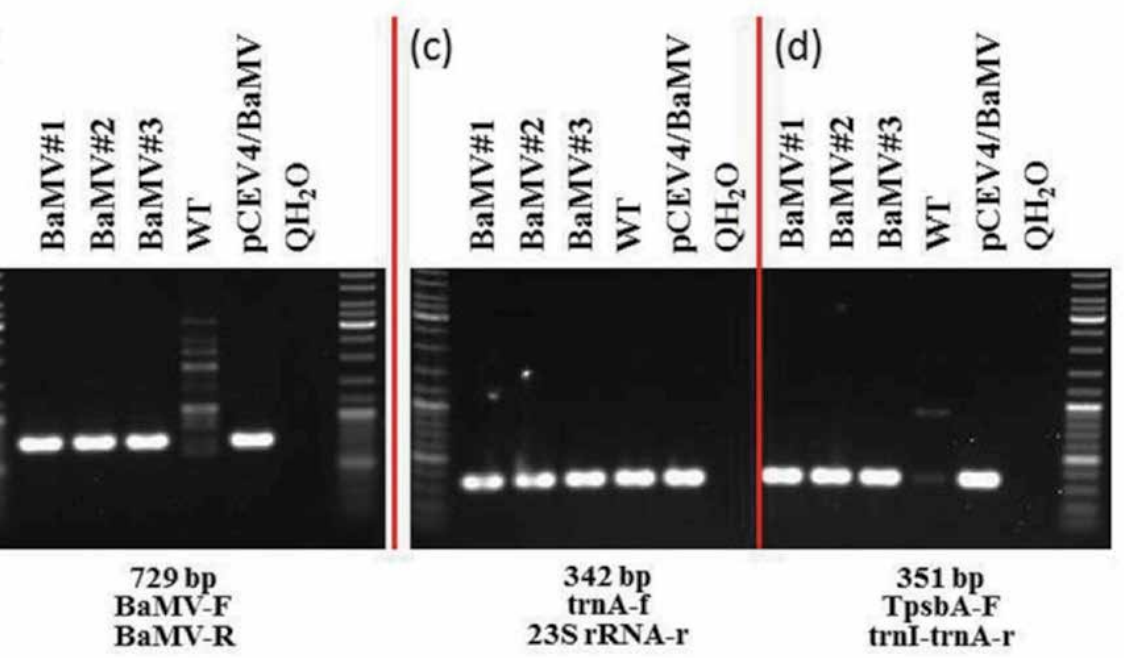

Figure 10.

$P C R$ analysis of three random-selected $T_{1}$ transplastomic Nicotiana benthamiana plants bombarded by pCEV4/BaMV. (a) Schematic representation of $p C E V 4 / B a M V$. Sizes and locations of gene-specific PCR products were indicated. (b) PCR analysis for transgene BaMV (729 bp). PCR products were only detected in three transplastomic lines but not in the WT plant. (c) PCR analysis of the internal trnA/23S rRNA region $(342 \mathrm{bp})$. PCR products were detected in WT and three transplastomic lines. (d) PCR analysis of the flanking region (351 bp). PCR products were detected in three transplastomic lines but not in the WT plant. "Q $\mathrm{H}_{2} \mathrm{O}$ " in each panel represented the negative control to which no DNA was added in the reaction mixture for PCR amplification. 
A unique band of $729 \mathrm{bp}$, which is the size of CP20 encoding gene (without $5^{\prime}$-UTR and $3^{\prime}$-UTR) in the transforming vector $\mathrm{pCEV} 4 / \mathrm{BaMV}$, was detected in all $\mathrm{T}_{1}$ transplastomic lines BaMV\#1, BaMV\#2, and BaMV\#3 but not in the WT plant (Figure 10b). Again, the same PCR primer set was employed for the amplification between $\operatorname{trn} A$ and $23 S r R N A$ in the plastid genome of $N$. benthamiana. As expected, a unique band of $0.3 \mathrm{~kb}$ was detected in all three transplastomic lines and the WT plant (Figure 10c). A unique band of $351 \mathrm{bp}$, representing the flanking sequence around the integration site at the RTR (i.e., $\mathrm{Nb} \operatorname{trn} \mathrm{A} / 23 \mathrm{~S}$ ), was only detected in the three transplastomic lines but not in the WT sample (Figure 10d). Here we clearly demonstrated the expression cassette carrying CP20 encoding gene and aadA gene was integrated into the $\operatorname{trnI} / \operatorname{trn} A$ site of the plastid genome in $N$. benthamiana via homologous recombination and the transgene was transmitted into progeny by maternal inheritance.

\subsection{Bombardment in tomato}

After bombardment, almost all tomato leaf explants turned brown and finally died in SL selection medium containing $300 \mathrm{mg} \mathrm{l}^{-1}$ spectinomycin (for pCEV2/GFP-GUS) or $50 \mathrm{mg} \mathrm{l}^{-1}$ kanamycin (for pCEV3/GFP-GUS). Eventually, at least two green calli were obtained for each construct (Figure A5) from hundreds of explants examined. Currently, plant regeneration from spectinomycin-resistant calli is also in progress.

\section{Conclusion}

Here we constructed a series of chloroplast expression vectors specific for spinach (pCEV1), tomato (pCEV2 and pCEV3), and N. benthamiana (pCEV4). Common features of these vectors are described as follows: (1) sequence of cloning sites (NotI, SacII, AscI) for the GOI is located between plastid atpI promoter and plastid rps16 terminator; (2) selection marker $a a d A$ or nptII is located between plastid rrn promoter and plastid $p s b A$ terminator; (3) longer LTR (ca. $2 \mathrm{~kb}$ ) contains partial $16 S$ $r R N A$ and $t r n I$ in the plastid genome; (4) longer RTR (ca. $2 \mathrm{~kb}$ ) contains $t r n A$ and partial $23 S r R N A$ in the plastid genome; (5) the integration site for the expression cassette is located in the intergenic spacer between $\operatorname{trnI}$ and $\operatorname{trn} A$; and (6) the backbone plasmid is pUC19 (carrying ampicillin resistant marker gene).

Another feature of this study is the construction of the so-called "auxiliary vector" pECaad (Figure 6a) and pECnpt (Figure 6b). Briefly, DNA fragment of expression cassette, which consists of (1) GOI cloning sites (NotI, SacII, AscI) flanked by atpI promoter and rps16 terminator and (2) selection marker gene aadA or $n p t I I$ flanked by $r m$ promoter and $p s b A$ terminator, was ligated with pUC19 (carrying ampicillin resistant marker gene), generating pECaad or pECnpt. LTR can be inserted into the $5^{\prime}$ terminus of the expression cassette, RTR can be inserted into the $3^{\prime}$ terminus of the expression cassette, and GOI can be cloned into the cloning sites (NotI, SacII, AscI) within the expression cassette. Thus, a new vector suitable for other new plant species can be rapidly and efficiently constructed. We believe that our auxiliary vectors pECaad and pECnpt will aid the faster construction of new chloroplast expression vectors for other plant species.

\section{Acknowledgements}

The authors greatly acknowledge Dr. Na-Sheng Lin, Institute of Plant and Microbial Biology, Academia Sinica, for providing plasmids pBSL6 and pBS2-8. We 
thank the Transgenic Core Facility of Academia Sinica for the biolistic bombardment assistance. We appreciate Miranda Loney for editing the manuscript. This work was financially supported by Academia Sinica of Taiwan to Dr. Kin-Ying To.

\section{Abbreviations}

2,4-D 2,4-dichlorophenoxyacetic acid

add aminoglycoside 3 '-adenyltransferase

BA $\quad \mathrm{N}^{6}$-benzyladenine

$\mathrm{GA}_{3} \quad$ gibberellic acid

GFP green fluorescent protein

GOI gene of interest

GUS $\quad \beta$-glucuronidase

LCY lycopene $\beta$-cylase

LTR left targeting region

MS Murashige and Skoog (1962)

NAA $\alpha$-naphthaleneacetic acid

nptII neomycin phosphotransferase II

RTR right targeting region

ZDS $\quad \zeta$-carotene desaturase

\section{Appendix}

\begin{tabular}{|c|c|c|c|}
\hline Name of primer & Sequence $\left(5^{\prime} \rightarrow 3^{\prime}\right)$ & $\begin{array}{l}\text { PCR } \\
\text { size } \\
(b p)\end{array}$ & Purpose \\
\hline SacI+16S/trnI-F & AAGAGCTCTACCAAGCTGGAGTACGG & \multirow[t]{2}{*}{2020} & \multirow{16}{*}{$\begin{array}{l}\text { Cloning of } \\
\text { pCEV1 and } \\
\text { derivatives }\end{array}$} \\
\hline $16 S / \operatorname{trnI}+$ KpnI-R & AAGGTACCTGGGCCATCCTGGACTTGAACCAG & & \\
\hline $\begin{array}{l}\text { PstI+trnA/23S- } \\
\text { F(PstI) }\end{array}$ & AACTGCAGCTGCGCCAGGGAAAAGAATAAGAA & \multirow[t]{2}{*}{2032} & \\
\hline $\operatorname{trn} \mathrm{A} / 23 \mathrm{~S}+$ PstI-R & AACTGCAGACCGCTCTCGCGGCCCGCACCGAA & & \\
\hline $\begin{array}{l}\text { aadA-F1 } \\
\text { (BamHI) }\end{array}$ & CGGGATCCATGAGGGAAGCGGTGATCCC & \multirow[t]{2}{*}{808} & \\
\hline aadA-R1 (XbaI) & GCTCTAGATTATTTGCCGACTACCTTGGTGAT & & \\
\hline TpsbA-F (XbaI) & GCTCTAGAGATCCTGGCCTAGTCTATAGG & \multirow[t]{2}{*}{238} & \\
\hline TpsbA-R (PstI) & AACTGCAGAAACAAATACAAAATCAAAAT & & \\
\hline Prrn-F (KpnI) & GGGGTACCATCAGTTCGAGCCTGATTATCCCTAAG & \multirow[t]{2}{*}{235} & \\
\hline Prrn-R (BamHI) & CGGGATCCGTAGACAAAGCGGATTCGGAA & & \\
\hline PatpI-F (KpnI) & AAGGTACCTCTAGCTATATAAGAAATCCTTG & \multirow[t]{2}{*}{268} & \\
\hline $\begin{array}{l}\text { PatpI-R (NotI, } \\
\text { SacII) }\end{array}$ & AACCGCGGCCGCTGCCTTGCCCTCTGAAAAAATTG & & \\
\hline $\begin{array}{l}\text { Trps16-F (SacII, } \\
\text { AscI) }\end{array}$ & AACCGCGGCGCGCCTCAACCGAAATTCAATTAAGGA & \multirow[t]{2}{*}{191} & \\
\hline Trps16-R (KpnI) & AAGGTACCGTTATAGAACACGGAATTCAATGG & & \\
\hline NotI+LCY-F & AAGCGGCCGCATGGATACTTTGTTGAAAACCCC & \multirow[t]{2}{*}{1523} & \\
\hline LCY-AscI-R & AAGGCGCGCCTCATTCTTTATCCTGTAACAAATTG & & \\
\hline
\end{tabular}




\begin{tabular}{|c|c|c|c|}
\hline Name of primer & Sequence $\left(5^{\prime} \rightarrow 3^{\prime}\right)$ & $\begin{array}{l}\text { PCR } \\
\text { size } \\
(b p)\end{array}$ & Purpose \\
\hline NotI+ZDS-F & AAGCGGCCGCATGGCTACTTCTTCAGCTTATCTT & 1787 & \\
\hline ZDS-AscI-R & AAGGCGCGCCTCAGACAAGACTCAACTCATCAG & & \\
\hline NotI-mGFP5-F & GGTTGCGGCCGCATGGTAGATCTGACTAGTAAAGG & 2592 & \\
\hline GUSA-AscI-R & GATAGGCGCGCCTCACACGTGGTGGTGGTGG & & \\
\hline SacI+PatpI-F & AAGAGCTCTCTAGCTATATAAGAAATCCT & 1700 & $\begin{array}{l}\text { Cloning of pCEV2, } \\
\text { pCEV3, and } \\
\text { derivatives }\end{array}$ \\
\hline TpsbA-PstI-R & AACTGCAGAAACAAATACAAAATCAAAAT & & \\
\hline SacI $+16 S /$ trnI-F & AAGAGCTCTACCAAGCTGGAGTACGGTAGG & 2010 & \\
\hline $\begin{array}{l}\text { Le-16S/trnI } \\
+ \text { SacI-R }\end{array}$ & AAGAGCTCTGGGCCATCCTGGACTTGAAC & & \\
\hline $\begin{array}{l}\text { Le-PstI+trnA/ } \\
23 \mathrm{~S}-\mathrm{F}\end{array}$ & AACTGCAGCTGCGCCAGGGAAAAGAATAG & 2020 & \\
\hline $\operatorname{trnA} / 23 \mathrm{~S}+\mathrm{PstI}-\mathrm{R}$ & AACTGCAGACCGCTCTCGCGGCCCGCACCGAA & & \\
\hline BamHI+NPTII-F & AAGGATCCATGATTGAACAAGATGGATTG & 811 & \\
\hline XbaI+NPTII-R & AATCTAGATCAGAAGAACTCGTCAAGAAG & & \\
\hline $\begin{array}{l}\text { Nb-SacI } \\
+16 \mathrm{~S} / \text { trnI-F }\end{array}$ & AAGAGCTCTACCAAGCTGGAGTACGGTAGG & 2005 & $\begin{array}{l}\text { Cloning of pCEV4 } \\
\text { and derivatives }\end{array}$ \\
\hline $\begin{array}{l}\text { Nb-16S/trnI } \\
+ \text { SacI-R }\end{array}$ & AAGAGCTCTGGGCCATCCTGGACTTGAACC & & \\
\hline $\begin{array}{l}\text { Nb-PstI+trnA/ } \\
23 \mathrm{~S}-\mathrm{F}\end{array}$ & AACTGCAGCTGCGCCAGGGAAAAGAATAGA & 1918 & \\
\hline $\begin{array}{l}\text { Nb-trnA/23S } \\
+ \text { PstI-R }\end{array}$ & AACTGCAGACCGCTCTCGCGGCCCGCACCG & & \\
\hline NotI-BaMV_S-F & GGTTGCGGCCGCATGTCTGGAGCTGGAACGG & 753 & \\
\hline $\begin{array}{l}\text { BaMV_S_CP- } \\
\text { AscI-R }\end{array}$ & GATAGGCGCGCCTTAGTCTGATGTTGGTTCGG & & \\
\hline NotI-BSL6-F & GGTTGCGGCCGCGAAAACTCACCGCAACGA & 861 & \\
\hline BSL6-AscI-R & GATAGGCGCGCCCATCTTTTAACGTCTTTATTCGG & & \\
\hline BSL6-F & GAAAACTCACCGCAACGA & 837 & $\begin{array}{l}\text { Transgenic plant } \\
\text { verification }\end{array}$ \\
\hline BSL6-R & CATCTTTTAACGTCTTTATTCGG & & \\
\hline BaMV-F & ATGTCTGGAGCTGGAACGG & 729 & \\
\hline BaMV-R & TTAGTCTGATGTTGGTTCGGG & & \\
\hline TpsbA-F & GATCCTGGCCTAGTCTATAG & 351 & \\
\hline $\operatorname{trnI}-\operatorname{trn} A-r$ & ACCCGTAATCGCAACGAC & & \\
\hline $\operatorname{trn} A-f$ & GGATGTCAGCGGTTCGAGTC & 342 & \\
\hline 23S rRNA-r & CCTGCCCATGGATTCAGCAG & & \\
\hline
\end{tabular}

Table A1.

List of PCR primers for vector construction and transgenic plant verification. 

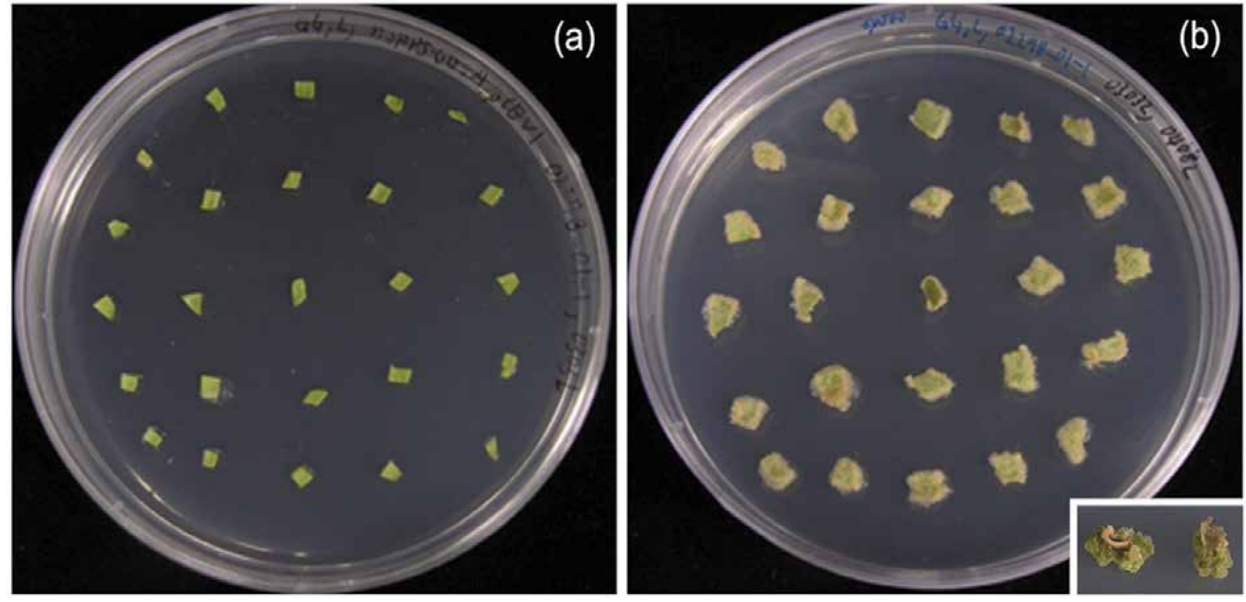

Figure A1.

Development of stable plastid transformation in spinach. Plastid vectors $p C E V_{1} / L C Y, p C E V_{1} / Z D S$, and $p C E V 1 / G F P-G U S$ were delivered individually into spinach leaves by bombardment. (a) After bombardment, leaf segments were cultured onto callus induction medium (MS salts and vitamins; $3 \%$ sucrose; $1 \mathrm{mg} \mathrm{l}^{-1} \mathrm{BA}$; $0.4 \mathrm{mg} \mathrm{l}^{-1} \mathrm{NAA}$; $0.8 \%$ Bacto agar; $\mathrm{pH}$ 5.8) supplemented with $300 \mathrm{mg} \mathrm{l}^{-1}$ spectinomycin. (b) After culturing for 1 month, almost all the leaf pieces turned brown in color and finally died. Occasionally, green calli from a few leaf pieces were observed after several bombardments and then picked up for plant regeneration, as indicated in the small panel in $(b)$.

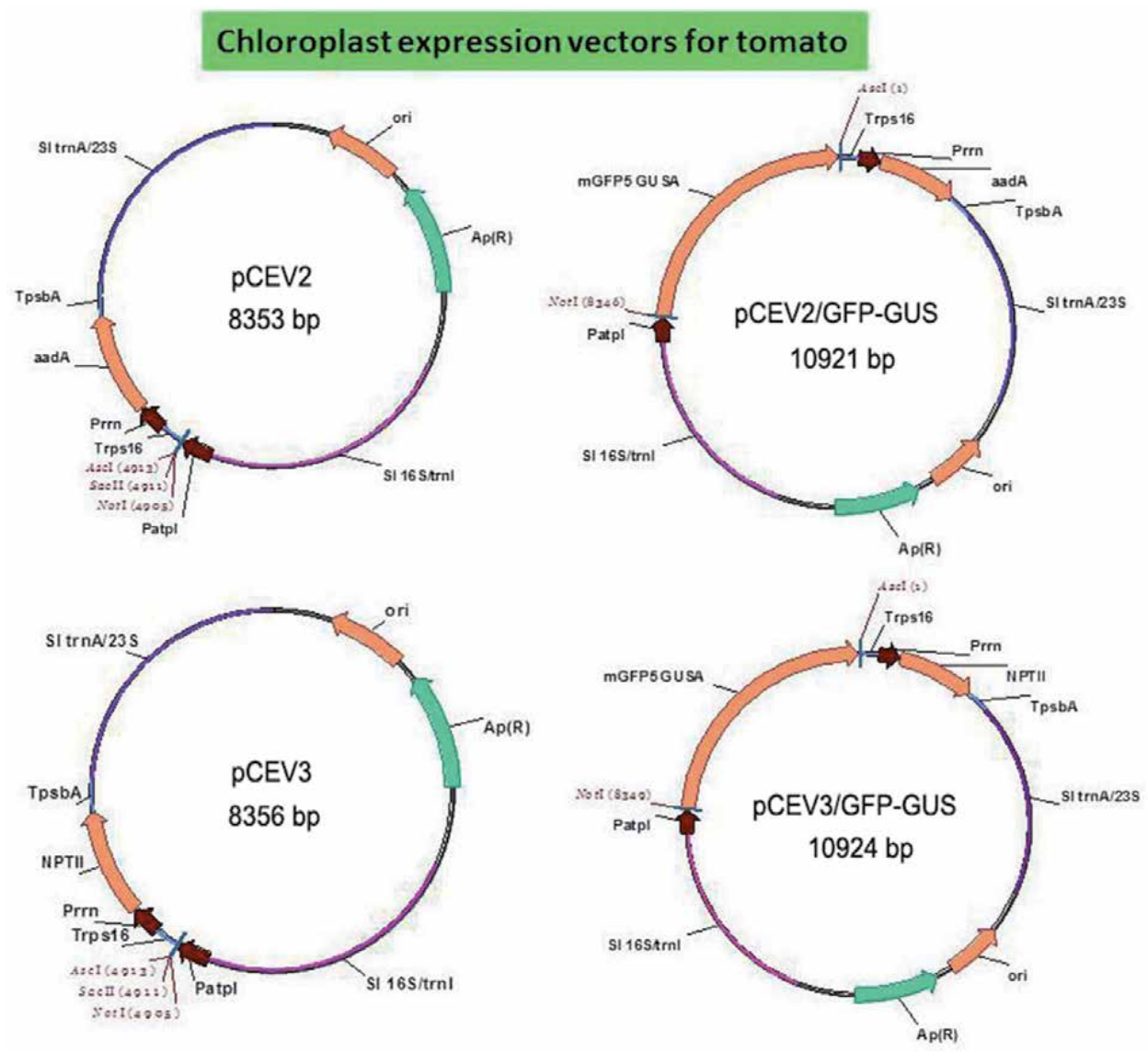

Figure A2.

Construction of chloroplast expression vectors for tomato. 
N. tabacum CTACCAAGCTGGAGTACGGTAGGGGCAGAGGGAATITCGGGGGAGCGGTGAAATGCGTAGAGATCGGAAAGAACACCAACGGCGAAAGCACTCTGCTGC N. benthamiana
$N$. benthamiana N. tabacum GCCGACACTGACACTGAGAGACGAAAGCTAGGGGAGCGAATGGGATTAGATACCCCAGTAGTCCTAGCCGTAAACGATGGATACTAGGCGCTGTGCGTAT N. benthamians GCCGACACTGACACTGAGAGACGAAAGCTAGGGGAGCGAATGGGATTAGATACCCCAGTAGTCCTAGCCGTAAACGATGGATACTAGGCGCT GTGCGTAT

N. tabacum CGACCCGTGCAGTGCTGTAGCTAACGCGTTAAGTATCCCGCCTGGGGAGTACGTTCGCAAGAATGAAACTCAAAGGAATTGACGGGGGCCCGCACAAGCG N. benthamiana CGACCCGTGCAGTGCTGTAGCTAACGCGTTAAGTATCCCGCCTGGGGAGTACGTTGGCAAGAATGAAACTCAAAGGAATTGACGGGGGCCCGCACAAGCG
$\mathrm{N}$. benthamiana N. tabacum GTGGAGCATGTGGTTTAATTCGATGCAAAGCGAAGAACCTTACCAGGGCTTGACATGCCGCGAATCCTCTTGAAAGAGAGGGGTGCCTTCGGGAACGCGG N. benthamiana GTGGAGCATGTGGTTTAATTCGATGCAAAGCGAAGAACCTTACCAGGGCTTGACATGCCGCGAATCCTCTTGAAAGAGAGGGGTGCCTTCGGGAACGCG

N. tabacum ACACAGGTGGTGCATGGCTGTCGTCAGCTCGTGCCGTAAGGTGTTGGGTTAAGTCCCGCAACGAGCGCAACCCTCGTGTTTAGTTGCCATCGTTGAGTTT N. Denthamiana ACACAGGTGGTGCATGGCTGTCGTCAGCTCGTGCCGTAAGGTGTTGGGTTAAGTCCCGCAACGAGCGCAACCCTCGTGTTTAGTTGCCATCGTTGAGTTT

N. tabacum GGAACCCTGAACAGACTGCCGGTGATAAGCCGGAGGAAGGTGAGGATGACGTCAAGTCATCATGCCCCTTATGCCCTGGGCGACACACGTGCTACAATGG N. benthamiana GGAACCCTGAACAGACTGCCGGTGATAAGCCGGAGGAAGGTGAGGATGACGTCAAGTCATCATGCCCCTTATGCCCTGGGCGACACACGTGCTACAATGC N. benthamiana* N. tabacum CCGGGACAAAGGGTCGCGATCCCGCGAGGGTGAGCTAACCCCAAAAACCCGTCCTCAGTTCGGATTGCAGGCTGCAACTCGCCTGCATGAAGCCGGAATC
N. benthamiana CCGGGACAAAGGGTCGCGATCCCGCGAGGGTGAGCTAACCTCAAAAACCCGTCCTCAGTTCGGATTGCAGGCTGCAACTCGCCTGCATGAAGCCGGATT
N. Denthamiana * N. tabacum GCTAGTAATCGCCGGTCAGCCATACGGCGGTGAATTCGTTCCCGGGCCTTGGTACACACCGCCCGTCACACTATGGGAGCTGGCCATGCCCGAAGTCGTTA N. benthamiana, GCTAGTAATCGCCGGTCAGCCATACGGCGGTGAATTCGTTCCCGGGCCTTGTACACACCGCCCGTCACACTATGGGAGCTGGCCATGCCCGAAGTCGTTA
$\mathrm{N}$. benthamiana N. tabacum CCTTAACCGCAAGGAGGGGGATGCCGAAGGCAGGGCTAGTGACTGGAGTGAAGTCGTAACAAGGTAGCCGTACTGGAAGGTGCGGCTGGATCACCTCCTT Nenthamiana CCTTAACCGCAAGGAGGGGGATGCCGAAGGCAGGGCTAGTGACTGGAGTGAAGTCGTAACAAGGTAGCCG TACT GGAAGGTGCGGCTGGATCACCTCCT N. tabacum TTCAGGGAGAGCTAATGCTTGTIGGGTATTTTGGTTTGACACTGCTTCACACCCCCAAAAAAAA-GAAGGGAGCTACGTCTGAGTTAAACTTGGAGATGG N. benthamiana TTCAGGGAGAGCTAATGCTTGTTGGGTATTTTGGTTTGACACTGCTTCACACCCCCAAAAAAAAAGAAGGGAGCTACGTCTGAGTTAAACTTGGAGATGG

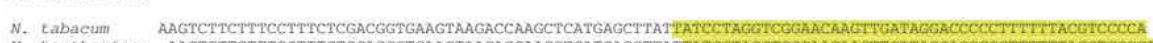
N. benthamiana AAGTCTTCTTTCCTTTCTCGACGGTGAAGTAAGACCAAGCTCATGAGCTTATTATCCRAGGTCGGAACAAGTTGATAGGACCCCCTITITTACGTECCGA
N. benthamiana*

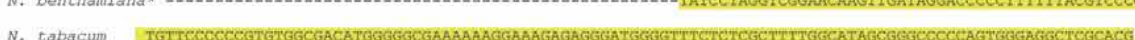

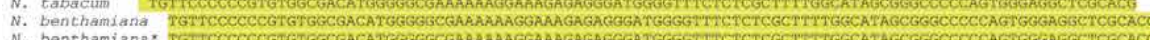

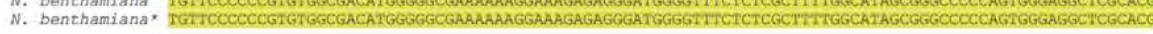

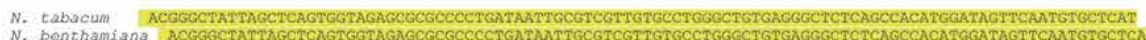

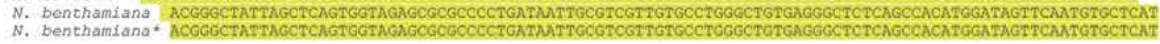
N. tabacum GGGCGCCTGACCCTGAGATGTGGATCATCCAAGCCACATRAGCATGGCGTACTCCTCCTGTTCGAACCGGGGTTLCAAACCAAACTCCTCCCTCAGGAGGA

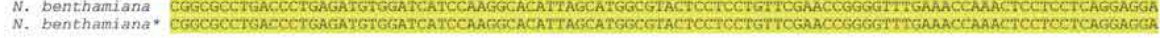

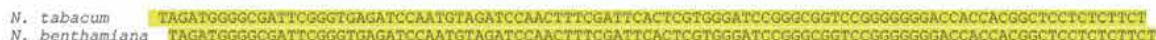

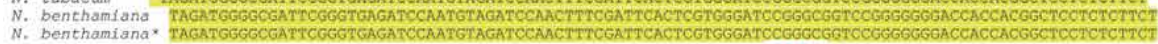

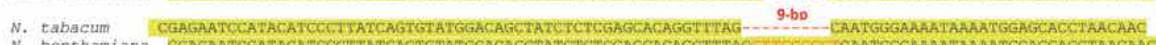

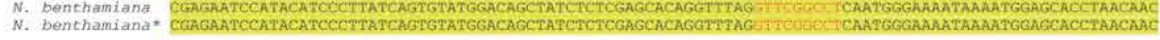

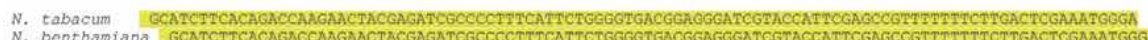

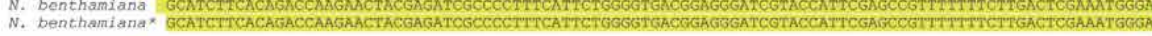

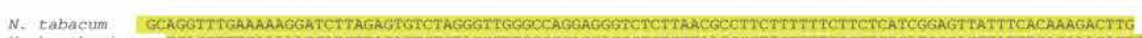
N. benthamiana GCACGTTTGAAAAAGGATCTTAGAGTGTCTACGGTTGGGCCAGGAGGGTCTCTTAACGCCTTCTITTTTCTTCTCATCGGAGTTATTTCACAAASACTTC
N. benthamiana N. CCAGEGTAAGGAAGAAGGGGEGAACAAGCACACTTGCAGAGCGCAGTACNACGGAGAGTTGTATECTGCGTTCGGGAAGGATGAATCGCTCCCGAMAAGS N. benthami ana CCAGGGTAAGGAAGAAGGGGGGAACAAGCACACTHGGAGAGCGCAGTACAACGGAGAGTTGTATGCTGCGTTCGGGAAGGATGAATCGCTCCCGAAAAAGG

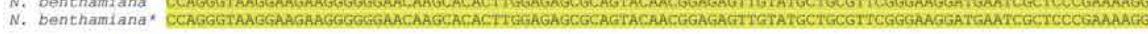

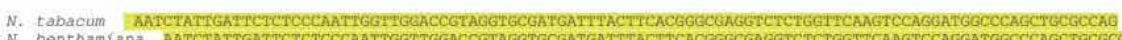

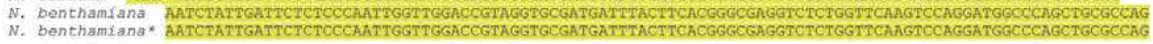

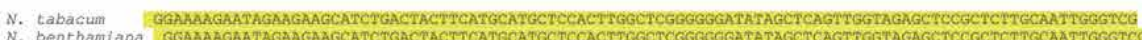

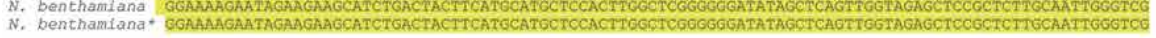
N. tabacum TIGCGATTACGGGT GGATGTCTAATT GTCCAGGCGGTAATGATAGTATCTTGTACCTGAACCGGTGGCTCACTITTTCTAXGTAATGGGGAAGAGGACC

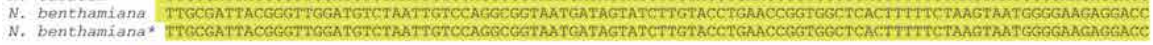
N. tabacuTa IGAAACGTGCCACTGNAAGACTCTAOTGAGACARAGATGGGCTGTCNAGAACGTAGAGGAGGTAGGATGGGCAGTTGETCNGATCTAGTATGGATCGTACA

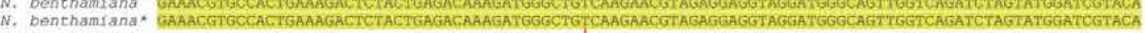

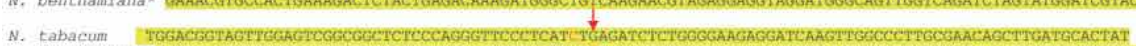

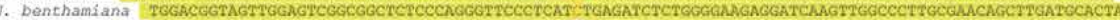

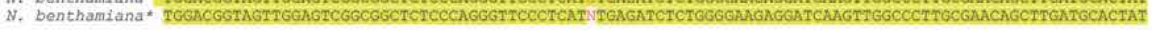
N. tabacum I ETCCETTCAACCCITTGAGCGAAATGCGGCAAAAGAAAAGGAANGGAAAATCCETGGACCGACCCCCATCATCTCCACCCCCGPAGGAACTACGGAGATCACCE

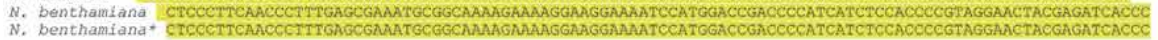
N. Tabacum ICAAGGACGCETTCGGCATCCAGGGGTCACGBACCGACCATAGNACCCTGWTCAATAAGTGGAACGCATTAGCTGTCCGCTCTCAGGTHGGGCAGTCAGGG

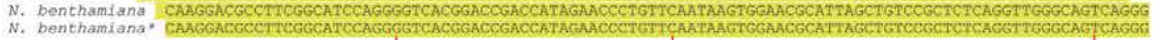

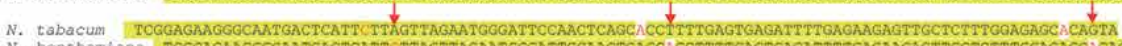

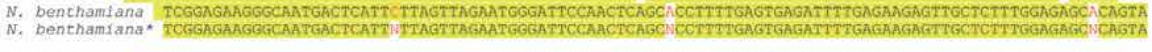

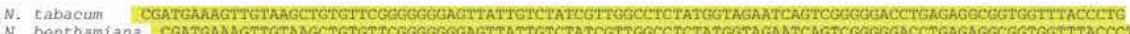

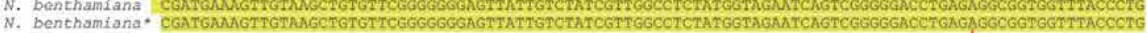

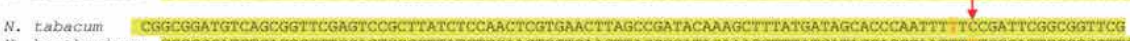

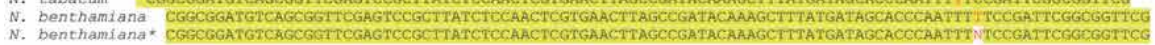
N. tabacum ATCTATGATTIATCATTCATGGACOTTGATAAGATCCATCCATTTAGCAGCACCTTAGGATGGCATAGCCTTAAAAGTGAAGGGCGAGGTTCAAACGAGG $N$. benthamiana ATCTATGATTTATCAITCATGGACGTTGATAAGATCCATCCATTTAGCAGCACCTTAGGATGGCATAGCCTTAAAAGTGAAGGGCGAGGTTCAAACGAGG
$\mathrm{N}$, benthamiana* ATCTATGATTTATCATTCATGGACG1- 
Construction and Evaluation of Chloroplast Expression Vectors in Higher Plants

DOI: http://dx.doi.org/10.5772/intechopen.91887

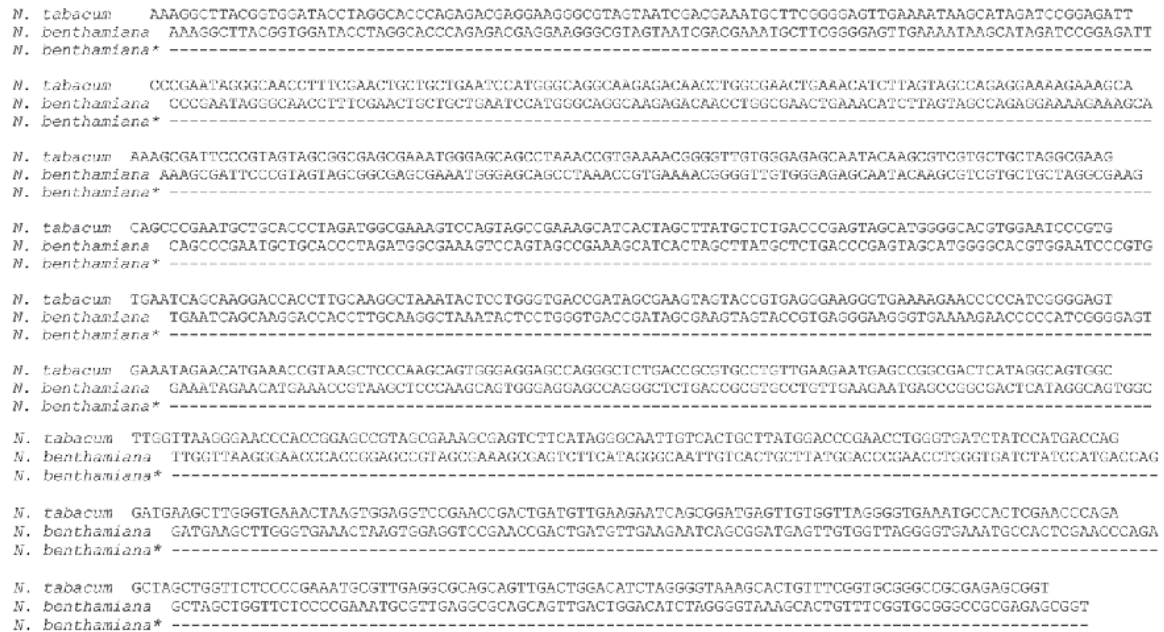

Figure A3.

Sequence comparison for the targeting region (partial $16 \mathrm{~S} \mathrm{rRNA}, \operatorname{trnI}$, trnA, and partial $23 \mathrm{~S} \mathrm{rRNA}$ ) between $\mathrm{N}$. tabacum and N. benthamiana. N. tabacum sequence was extracted from NCBI Accession no. NC_o01879. $\mathrm{N}$. benthamiana sequence ( $3893 \mathrm{bp}$ ) was our PCR product. N. benthamiana* sequence (1874 bp) was the partial sequence of 16S-23S ribosomal RNA intergenic spacer from NCBI with the Accession no. FJ217346. A different nucleotide was indicated by red arrow and labeled with a red letter. Common region in these three sequences was highlighted in yellow color.

\section{Chloroplast expression vectors for Nicotiana benthamiana}
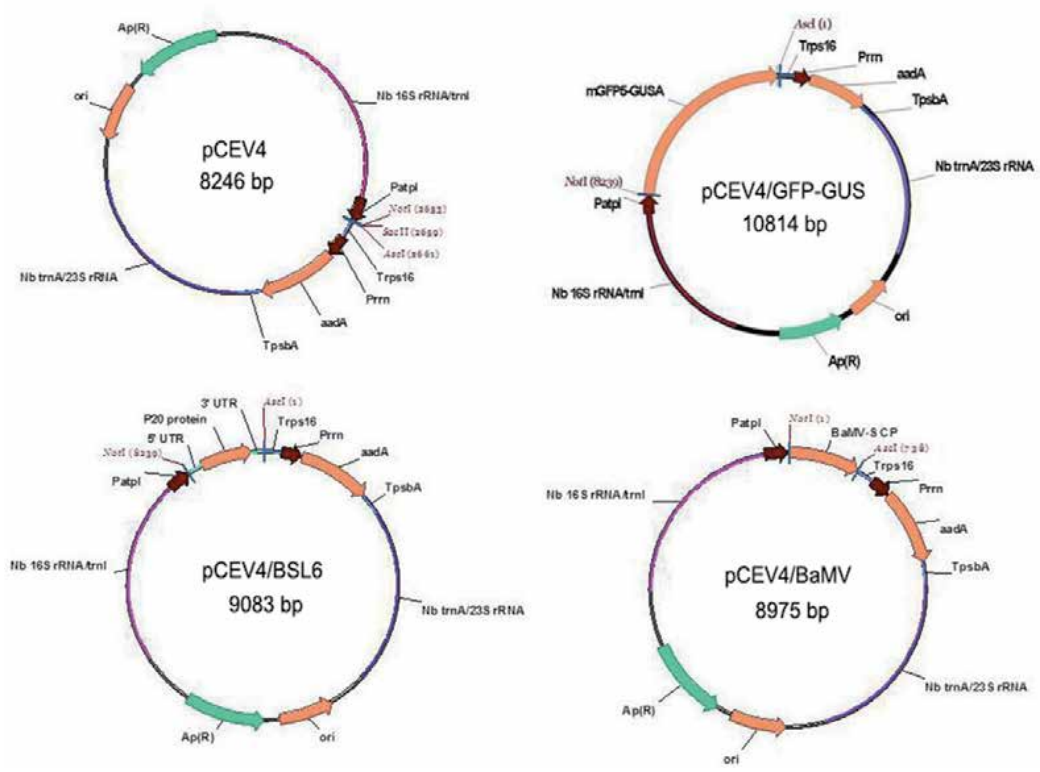

Figure A4.

Construction of chloroplast expression vectors for Nicotiana benthamiana. 


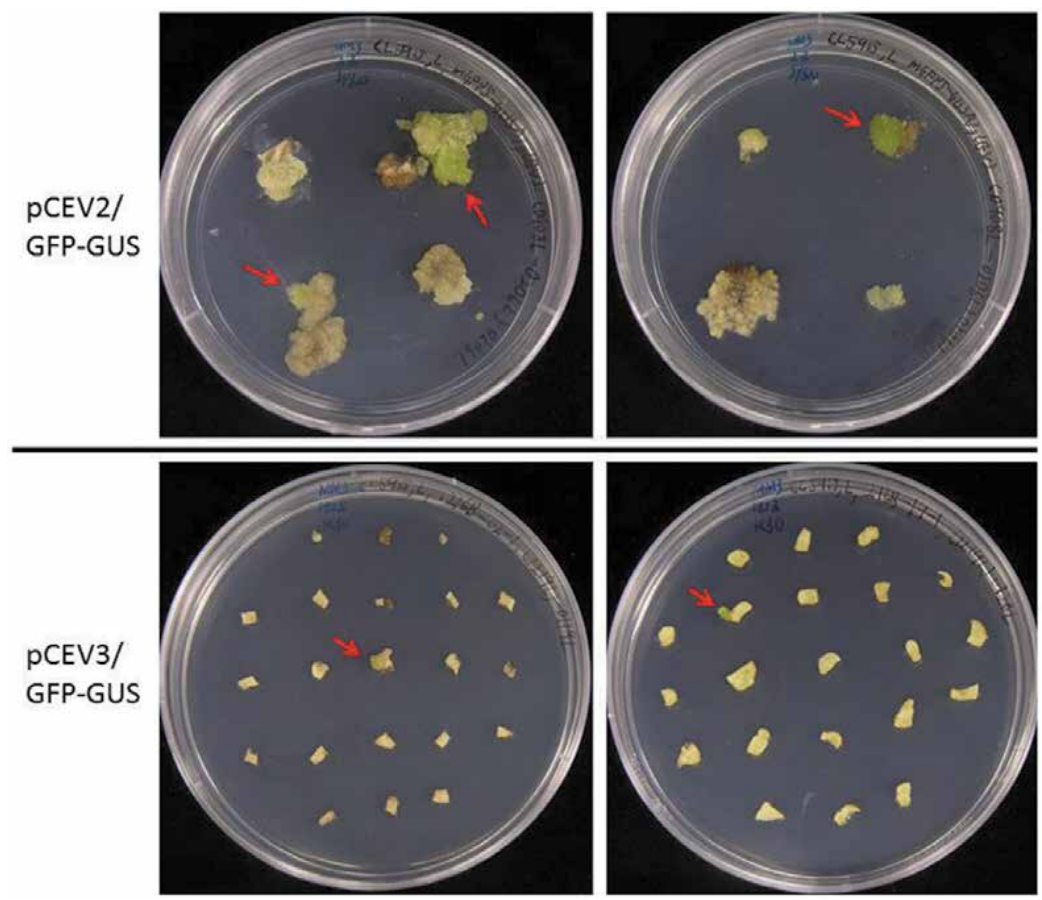

Figure A5.

Selection of survival calli in tomato plastid transformation. Plastid vector $p C E V_{2} / G F P$-GUS (carrying selection marker aadA) or $p C E V_{3} / G F P-G U S$ (carrying selection marker nptII) was bombarded into tomato leaves. Leaf segments were cultured for 1 month on callus induction medium (MS salts and vitamins; $3 \%$ sucrose; $1 \mathrm{mg} \mathrm{l}^{-1} \mathrm{NAA} ; 1 \mathrm{mg} \mathrm{l}^{-1}$ Zeatin; o.8\% Bacto agar; $\mathrm{pH}$ 5.8) supplemented with $300 \mathrm{mg} \mathrm{l}^{-1}$ spectinomycin (for $p C E V_{2} / G F P-G U S$ ) or $50 \mathrm{mg} \mathrm{l}^{-1}$ kanamycin (for $\mathrm{pCEV} / \mathrm{GFP}-G U S$ ). Most of the leaf pieces turned brown and finally died. Several survival green calli (as indicated by red arrows) were observed and then picked for shoot regeneration.

\section{Author details}

Po-Yen Chen, Yung-Ting Tsai and Kin-Ying To*

Agricultural Biotechnology Research Center, Academia Sinica, Taipei, Taiwan

*Address all correspondence to: kyto@gate.sinica.edu.tw

\section{IntechOpen}

(C) 2020 The Author(s). Licensee IntechOpen. This chapter is distributed under the terms of the Creative Commons Attribution License (http://creativecommons.org/licenses/ by/3.0), which permits unrestricted use, distribution, and reproduction in any medium, provided the original work is properly cited. (c) BY 


\section{References}

[1] Verma D, Samson NP, Koya V, Daniell H. A protocol for expression of foreign genes in chloroplasts. Nature Protocols. 2008;3:739-758

[2] Bock R. Engineering plastid genomes: Methods, tools, and applications in basic research and biotechnology. Annual Review of Plant Biology. 2015;66: 211-241

[3] Jin S, Daniell H. The engineered chloroplast genome just got smarter. Trends in Plant Science. 2015;20: $622-640$

[4] Wani SH, Sah SK, Sági L, Solymosi K. Transplastomic plants for innovations in agriculture. A review. Agronomy for Sustainable Development. 2015;35: 1391-1430

[5] Ahmad N, Michoux F, Lössl AG, Nixon PJ. Challenges and perspectives in commercializing plastid transformation technology. Journal of Experimental Botany. 2016;67: 5945-5960

[6] Olejniczak SA, Lojewska E, Kowalczyk T, Sakowicz T. Chloroplasts: State of research and practical applications of plastome sequencing. Planta. 2016;244:517-527

[7] Ruf S, Hermann M, Berger IJ, Carrer H, Bock R. Stable genetic transformation of tomato plastids and expression of a foreign protein in fruit. Nature Biotechnology. 2001;19:870-875

[8] Kumar S, Dhingra A, Daniell H. Plastid-expressed betaine aldehyde dehydrogenase gene in carrot cultured cells, roots, and leaves confers enhanced salt tolerance. Plant Physiology. 2004; 136:2843-2854

[9] Kumar S, Dhingra A, Daniell H. Stable transformation of the cotton plastid genome and maternal inheritance of transgenes. Plant Molecular Biology. 2004;56:203-216

[10] Chen PJ, Senthilkumar R, Jane WN, He Y, Tian Z, Yeh KW. Transplastomic Nicotiana benthamiana plants expressing multiple defence genes encoding protease inhibitors and chitinase display broad-spectrum resistance against insects, pathogens and abiotic stresses. Plant Biotechnology Journal. 2014;12:503-515

[11] Wang HM, To KY. Agrobacteriummediated transformation in the highvalue medicinal plant Echinacea purpurea. Plant Science. 2004;166: 1087-1096

[12] Wang HM, Jeng ST, To KY. In vitro regeneration, Agrobacterium-mediated transformation, and genetic assay of chalcone synthase in the medicinal plant Echinacea pallida. Plant Cell, Tissue and Organ Culture. 2017;130:117-130

[13] Wang CK, Chen PY, Wang HM, To KY. Cosuppression of tobacco chalcone synthase using Petunia chalcone synthase construct results in white flowers. Botanical Studies. 2006;47:71-82

[14] Wang CK, Hsu SY, Chen PY, To KY. Transformation and characterization of transgenic Bidens pilosa L. Plant Cell, Tissue and Organ Culture. 2012;109: 457-464

[15] Tsai YT, Chen PY, To KY. Plant regeneration and stable transformation in the floricultural plant Cleome spinosa, a $\mathrm{C}_{3}$ plant closely related to the $\mathrm{C}_{4}$ plant C. gynandra. Plant Cell Reports. 2012;31: 1189-1198

[16] Day A, Goldschmidt-Clermont M. The chloroplast transformation toolbox: Selection markers and marker removal. Plant Biotechnology Journal. 2011;9: 540-553 
[17] Tabatabaei I, Ruf S, Bock R. A bifunctional aminoglycoside acetyltransferase/phosphotransferase conferring tobramycin resistance provides an efficient selection marker for plastid transformation. Plant Molecular Biology. 2017;93:269-281

[18] Al-Khayri JM, Huang FH, Morelock TE, Busharar TA, Gbur EE. Genotype-dependent response to spinach cultivars to in vitro callus induction and plant regeneration. Plant Science. 1991;78:121-127

[19] Molvig L, Rose RJ. A regeneration protocol for Spinacia oleracea using gibberellic acid. Australian Journal of Botany. 1994;42:763-769

[20] Yang Y, Al-Khayri JM, Anderson EJ. Transgenic spinach plants expressing the coat protein of cucumber mosaic virus. In Vitro Cellular \&

Developmental Biology_Plant. 1997;33: 200-204

[21] Zhang HX, Zeevarrt JAD. An efficient Agrobacterium tumefaciensmediated transformation and regeneration system for cotyledons of spinach (Spinacia oleracea L.). Plant Cell Reports. 1999;18:640-645

[22] Schmitz-Linneweber C, Maier RM, Alearaz J-P, Cottet A, Herrmann RG, Mache R. The plastid chromosome of spinach (Spinacia oleracea): Complete nucleotide sequence and gene organization. Plant Molecular Biology. 2001;45:307-315

[23] Wang HM, Yin WC, Wang CK, To KY. Isolation of functional RNA from different tissues of tomato suitable for developmental profiling by microarray analysis. Botanical Studies. 2009;50: $115-125$

[24] Vijayapalani P, Chen JCF, Liou MR, Chen HC, Hsu YH, Lin NS.

Phosphorylation of bamboo mosaic virus satellite RNA (satBaMV)-encoded
P20 downregulates the formation of satBaMV-P20 ribonucleoprotein complex. Nucleic Acids Research. 2012; 40:638-649

[25] Murashige T, Skoog F. A revised medium for the rapid growth and bioassays with tobacco culture. Physiologia Plantarum. 1962;15:473-497

[26] Wilkie S. Isolation of total genomic DNA. In: Clark MS, editor. Plant Molecular Biology-A Laboratory Manual. Berlin: Springer-Verlag; 1997. pp. 3-15

[27] Chen PY, Wang CK, Soong SC, To KY. Complete sequence of the binary vector pBI121 and its application in cloning T-DNA insertion from transgenic plants. Molecular Breeding. 2003;11:287-293

[28] Wang HM, To KY, Lai HM, Jeng ST. Modification of flower colour by suppressing $\beta$-ring carotene hydroxylase genes in Oncidium. Plant Biology. 2016; 18:220-229

[29] Kunnimalaiyaan M, Nielsen BL. Fine mapping of replication origins (ori $\mathrm{A}$ and ori $\mathrm{B}$ ) in Nicotiana tabacum chloroplast DNA. Nucleic Acids Research. 1997;25:3681-3686

[30] Fujitani Y, Yamamoto K, Kobayashi I. Dependence of frequency of homologous recombination on the homology length. Genetics. 1995;140: 797-809

[31] Ye GN, Daniell H, Sanford JC. Optimization of delivery of foreign DNA into higher-plant chloroplasts. Plant Molecular Biology. 1990;15: 809-819

[32] To KY, Cheng MC, Chen LFO, Chen SCG. Introduction and expression of foreign DNA in isolated spinach chloroplasts by electroporation. Plant Journal. 1996;10:737-743 
Construction and Evaluation of Chloroplast Expression Vectors in Higher Plants DOI: http://dx.doi.org/10.5772/intechopen.91887

[33] Davarpanah SJ, Jung SH, Kim YJ, Park YI, Min SR, Liu JR, et al. Stable plastid transformation in Nicotiana benthamiana. Journal of Plant Biology. 2009;52:244-250

[34] Carrer H, Hockenberry TN, Svab Z, Maliga P. Kanamycin resistance as a selectable marker for plastid transformation in tobacco. Molecular and General Genetics. 1993;241:49-56 



\title{
RNA Interference: An Overview
}

\author{
Jitesh Kumar, Khushbu Jain, Priyanka Kumari, \\ Auroshikha Mohanty, Kumari Rajani, \\ Ravi Ranjan Kumar and Tushar Ranjan
}

\begin{abstract}
In the course of transgenic experiments on the nematode Caenorhabditis elegans, RNA interference, usually abbreviated as RNAi, was discovered first. It is a gene-silencing effect and is found to be widely distributed in eukaryotes. It was observed that control injections of sense RNA were just as effective as antisense RNA, directed at specifically inhibiting target genes in C. elegans by the injection of antisense RNA during an experiment causing the reduction or elimination of expression from the gene under investigation. Subsequently, by injecting doublestranded RNA (dsRNA) corresponding to the target gene, it was discovered that the effect could be most potently elicited, and contamination of the single-stranded RNA (ssRNA; either sense or antisense) by traces of dsRNA could explain the earlier results. By post-transcriptional mechanism, substantial or complete inhibition of expression from any gene can be done using dsRNA corresponding to part or all of the mature mRNA from any given gene. An attempt was made here to describe the basic underlying molecular mechanism of RNAi, the methodology and various experimental requirements, and its advantages and disadvantages. In relation to CRISPR/Cas9 technology, the future prospects of virus-induced gene silencing (VIGS) are considered finally. For the cutting-edge CRISPR/Cas9 genome editing technology, VIGS has emerged as the preferred delivery system besides using it to overexpress or silence genes.
\end{abstract}

Keywords: RNAi, virus-induced gene silencing (VIGS), plant virus, CRISPR/Cas system

\section{Introduction}

A biological process where the expression of a particular gene is inhibited when specific mRNA molecules targeted and destructed by RNA molecule is known as RNA interference (RNAi). RNAi is otherwise called posttranscriptional gene silencing (PTGS), co-suppression, and quelling. The RNAi's disclosure was absolutely good fortune. The concept of RNAi for the first time came into the existence while the study of transcriptional inhibition by antisense RNA expressed in transgenic Petunia plant [1]. Scientists were trying to introduce these plant additional copies of chalcone synthase gene responsible for darker pigmentation of flowers. White or less pigmented flowers were observed instead of darker flowers, indicating the suppressed/ decreased expression of endogenous chalcone synthase gene $[1,2]$ when intended to make more corresponding gene products. This suggests a downregulation of 
endogenous gene by the event posttranscriptional inhibition due to their mRNA degradation $[3,4]$. Just after the discovery of plant defense mechanism against virus, where it was believed that plant encodes short, noncoding region of viral RNA sequences, silencing of target genes by RNA interference technology came into the lime light, which after contamination perceives and debases viral mRNA. These short and noncoding RNA arrangements may be against viral DNA/RNA polymerase and other significant genes essential for viral contamination and multiplication. On the topic of the above idea, plant virologist brought short nucleotides sequence into the viruses, and expression of target genes in the infected plants was seen as suppressed [5, 6]. This most mainstream marvel is known as "virus-induced gene silencing” (VIGS) and gets a blast of the time of biotechnologists. Craig Mello and Andrew Fire, after a year later in 1998, worked in the laboratory to study the effect of RNAi in Caenorhabditis. The term RNAi was coined by these two scientists for the first time, and they were awarded the Nobel Prize in 2006 [7]. After this incredible disclosure of double-stranded RNA (dsRNA) as an amazingly strong trigger for gene silencing, it turned out to be sensible to unwind the component of RNAi activity in different biological systems $[8,9]$. Protein apparatus important for gene silencing was found in C. elegans without precedent for 1999, and thorough examination shows that normal principal process must be worked all through the eukaryotes, for example, fungi, Drosophila, and plants [10]. Small RNA extending long from 21 to 23 nucleotides created from dsRNA in cell separates and could behave as de novo silencing trigger for RNAi in cell extracts free of dsRNA treatments. They reasoned that short 21-23 nucleotide siRNA are the result of Dicer and RNA-induced silencing complex (RISC) [11-13].

The short RNA molecules, a key to RNA interference technology, are of two sorts: (I) microRNA (miRNA) and (II) small interfering RNA (siRNA). miRNAs are endogenous or intentionally expressed product (organism own genome product), though siRNAs are inferred result of exogenous cause, for example, virus and transposon. Both have distinctive forerunner, for instance, miRNA processed from stem-loop with partial complementary dsRNA though siRNA shows up from fully complementary dsRNA [14]. In spite of these differences, both short nucleotides are very much related in terms of their biogenesis and mode of action [15].

\section{Basic components of RNAi}

\subsection{Dicer: a gateway into the RNA interference}

Dicer, a member of RNase III family proteins with dsRNA-specific nuclease activity and it act as a primary candidate for biogenesis of siRNA during gene silencing. These enzymes have a few basic motifs spread all through the polypeptide affix from $\mathrm{N}$-end to $\mathrm{C}$-end, which is liable for their productive execution [15]. RNase III proteins are portrayed by the spaces all together from $\mathrm{N}$ - to $\mathrm{C}$-end: a DEXD domain, a DUF283 domain, a Piwi/Argonaute/Zwille (PAZ) domain, two RNase III domains, and a dsRNA binding domain. Aside from ribonuclease explicit PAZ domain, Dicer do have helicase domain, and their capacity has been embroiled in preparing long dsRNA substrate [16]. Out of these five significant domains, PAZ and RNase III are basic for exact extraction of siRNA from dsRNA forerunner [17]. The duplex RNA ends with three nucleotides overhang, bringing about extending of two helical turns along the outside of the protein perceived by PAZ domain. This prompts the cleavage of each out of the two strands in turn by two diverse RNase III 
domains independently. The last product after Dicer activity is 21-23-nt-long fragments with two nucleotides overhang at $3^{\prime}$ end, which currently go about as a substrate for RISC [14]. Current finding recommends that PAZ domain is fit for restricting the precisely two nucleotide $3^{\prime}$ overhang of dsRNA, while the RNase III catalytic domains structure a pseudo dimer around the dsRNA to start cleavage of the strands. This results in a functional shortening of the dsRNA strand. The separation between the PAZ and RNase III domains is controlled by the angle of the connector helix and impacts the length of the microRNA product [18]. In some of the organism, just one copy of Dicer is answerable for the processing of both miRNA and siRNA; however in Drosophila, Dicer 1 is exclusively dedicated for miRNA biogenesis, while Dicer 2 is utilized for siRNA track [14]. Other variants of Dicer are characterized by the absence of ATPase domain or PAZ domain or RNA binding domains. Although functional ATPase domain is not very necessary for the action of Dicer to the substrate molecules, studies also give a clue that ATPase domain is very critical for switching/movement of both RNase III domains, and biochemical studies indicate mutation in ATPase domain leads to the abolishment of siRNA procession [14].

\subsection{RISC: at the center of RNA interference}

RISC is a generic term for a family of heterogeneous molecular complexes that can be programmed to target almost any gene for silencing. In the cytoplasm of a eukaryotic cell, RISC programming is triggered by the appearance of dsRNA. RISC is a multiprotein complex composed of ribonucleoproteins (Argonaute protein), incorporating one strand of dsRNA fragments (siRNA, miRNA) to the target transcripts. Two proteins of $\sim 100 \mathrm{kDa}$ were also identified that corresponded to Argonaute 1 and Argonaute 2 (Ago1 and Ago2). A variety of different ribonucleoproteins, ranging from modest size $(150 \mathrm{kDa})$ up to $3 \mathrm{MDa}$ particle termed "holo-RISC," have been revealed by the biochemical isolations of RISC, and many other intermediate sizes have also been observed [19-21]. A large number of RISC-associated proteins have been reported from recent research which mainly includes Argonaute proteins and RISC-loading complex. Both these components assembled together to perform its functions efficiently. RISC-loading complex is basically made up of Dicer, Argonaute, and TRBP (protein with three doublestranded RNA binding domains) [22] that identified a $500 \mathrm{kDa}$ insignificant RISC by portraying proteins that copurified with human Dicer. Two proteins were seen as related with Dicer, Ago2, and TRBP (the HIV trans-activating response RNA-binding protein) [22]. Paralelly, the minimal RISC, sufficient for target RNA recognition and cleavage efficiently, was demonstrated to be simply an Argonaute protein bound to a small RNA [23]. Argonaute proteins are universally found in plant, animal, many fungi, protista, and even in some archaea also. Albeit every AGO protein harbor PAZ, MID (middle), and PIWI domains, they are isolated into three groups based on both their phylogenetic connections and their ability to tie to small RNAs. Group 1 individuals are alluded to as AGO proteins which bind to miRNAs and siRNAs. Group 2 members are referred to as PIWI proteins which bind to PIWI-interacting RNAs (piRNAs). Group 3 individuals have been depicted uniquely in worms, where they tie to secondary siRNAs. AGOs are large proteins (ca 90-100 kDa) comprising one variable N-terminal area and rationed C-terminal PAZ, MID, and PIWI domains. Experiments with bacterial and animal AGO proteins have clarified the roles of these three domains in small RNA pathways. The MID domain ties to the 5' phosphate of small RNAs, while the PAZ domain perceives the $3^{\prime}$ end of small RNAs. The PIWI domain adopts a collapsed structure 
like that of RNaseH proteins and shows endonuclease action, which is done by a functioning site typically conveying an Asp-Asp-His (DDH) motif [24].

The presence of these proteins has also been reported in prokaryotes, but their function in lower organisms is still a mystery. Among eukaryotes, number of Argonaute gene ranging from a single copy to dozens of copies (even more than two dozens) is found to be observed. Multiple copies (paralogous proteins) of Argonaute proteins in C. elegans reflect their functional redundancy, and their evolutionary significance remains unknown. Studies suggest genes for Argonaute proteins are ample to recompense for one another [25]. In association with siRNA, the Argonaute binds to the $3^{\prime}$-untranslated area of mRNA which prevents the creation of proteins in a few different ways. The enrollment of Argonaute proteins to focused mRNA can induce mRNA degradation. The Argonaute-miRNA complex can likewise impact the development of functional ribosomes at the $5^{\prime}$ end of the mRNA. The complex contends with the translation initiation factors and/or potentially repeals ribosome to get together. By recruiting cellular factors such as peptides or posttranslational modifying enzymes, the Argonaute-miRNA complex can adjust protein production, degrading the growth of polypeptides [26].

The Argonaute superfamily can be separately partitioned into three subgroups: the Piwi clade that ties to piRNAs, the Ago clade that associates with miRNAs and siRNAs, and a third clade that has just been found and portrayed in nematodes so far [27]. All gene regulatory phenomena including 20-30 nt RNAs are thought to require at least one Argonaute protein, and these proteins are the central, characterizing segments of the different types of RISC. The double-stranded products of Dicer enters into a RISC assembly pathway that involves duplex unwinding, culminating in the stable association of only one of the two strands with the Ago effector protein $[14,15]$. Thus, through Watson-Crick base pairing, one guide strand directs target recognition, while the other strand of the first little RNA duplex, known as the passenger strand, is disposed of. There are eight AGO relatives in human, some of which are examined seriously. Despite the fact that AGO1-AGO4 are equipped for stacking miRNA, endonuclease action and, however, RNAi subordinate gene silencing are solely found with AGO2. The uniqueness of AGO2 is presumed to arise from either the N-terminus or the spacing region linking PAZ and PIWI motifs, considering the sequence conservation of PAZ and PIWI domains across the family. In plants, a few AGO families additionally draw a tremendous effort of study. AGO1 is unmistakably engaged with miRNA-related RNA degradation and assumes a central role in morphogenesis. In certain organisms, it is carefully required for epigenetic silencing. Strangely, it is managed by miRNA itself. AGO4 does not include in RNAi-coordinated RNA degradation, yet it includes in DNA methylation and other epigenetic regulation through small RNA (siRNA) pathway. AGO10 is associated with plant development. AGO7 has a distinct function from AGO1 to AGO10 and is not included in gene silencing actuated by transgenes. Rather, it is identified with developmental timing in plants $[15,28]$. At the cell level, Ago proteins diffusely restrict in the cytoplasm and nucleus and sometimes, likewise at particular, foci which incorporate processing bodies (P-bodies) and stress granules. The subsequent clade, Piwi (named after the Drosophila protein PIWI, for P-component instigated weak testis), is communicated in germline cells most bounteously and has the capacity in the silencing of germline transposons. The means by which members acquire guide RNAs (gRNAs) is a major biochemical difference between Argonaute clades. In the cytoplasm, Ago guide RNAs are produced from dsRNA by a particular nuclease named Dicer. Individuals from the Piwi clade are thought to frame direct RNAs in a "ping-pong" component in which the objective RNA of one Piwi protein is severed and turns into the guide RNA of another Piwi protein. Maternally acquired guide piRNAs are accepted to start this gene-silencing cascade. 
Class 3 Argonautes get direct RNAs by Dicer-interceded cleavage of exogenous and endogenous long dsRNAs [27, 29, 30].

The hall mark domains of Argonaute proteins are N-terminal PAZ (like Dicer enzymes and offer basic developmental cause), mid domain and C-terminal PIWI domain, an interesting to the Argonaute superfamily proteins. The PAZ domain is named after the revelation of proteins PIWI, AGO, and Zwille, whereby it is found to be conserved. The PAZ domain interacts with $3^{\prime}$ end of both siRNA and miRNA in a sequence-independent manner, and finally it hybridizes via base-pairing interaction with the target mRNA, leading to the cleavage or translation and inhibition [31]. PIWI domain has structural resemblance with $\mathrm{RNaseH}$ which is very essential for RNA backbone cleavage. The active site which coordinates with divalent metal ion and provides binding energy for catalysis is composed of triad amino acids, aspartate-aspartate-glutamate. PIWI domain participates in interaction with the Dicer via one of the RNase III domains in few Argonaute proteins [15]. A MC motif is available between the Mid and PIWI domain, which is believed to be engaged with collaboration sites for the $5^{\prime}$ cap of siRNA/miRNA and control their translation [26]. The general structure of Argonaute is bilobed, with one flap comprising the PAZ domain and the other projection comprising the PIWI domain which is flanked by $\mathrm{N}$-terminal $(\mathrm{N})$ and center (Mid) domains. The Argonaute PAZ domain has RNA $3^{\prime}$ end binding activity and is used in guide strand binding revealed by the cocrystal structures. The other end of the guide strand engages a 5 ' phosphate binding pocket in the mid domain, and the remainder of the guide tracks along a positively charged surface to which each of the domains contributes. As expected for a protein that can accommodate a wide range of guide sequences, the protein-DNA contacts are dominated by sugar-phosphate backbone interactions. Guide strand that consists of 2-6 nucleotides which are important especially for target recognition is stacked with their exposed Watson-Crick faces and available for base pairing [32].

\section{Working principle of RNAi}

The RNAi pathway, ubiquitous to most of the eukaryotes consists of a short RNA molecule that binds to specific target mRNA to form a dsRNA hybrid and inactivates the mRNA by preventing it from producing a protein. It also influences the development of organisms, apart from their role in defense against viruses and protozoans. During RNAi, the dsRNA, introduced into cells by viral infection or artificial expression or formed in cells by DNA- or RNA-dependent synthesis of complementary strands, is processed to $20 \mathrm{bp}$ double-stranded siRNAs containing 2-nt 3' overhangs [33]. The siRNAs are then incorporated into an RNA-induced silencing complex, recognize the sequences fully complementary to the siRNA, and mediate the degradation of mRNAs (Figure 1) [34].

\subsection{Initiation: processing of precursor dsRNA}

In the cytoplasm, RNAi pathway, an RNA-dependent pathway, can be initiated by either exogenous or endogenous short dsRNA particles. The forerunner of siRNA, named as essential siRNA or pri-siRNA, creases back to frame a long stem circle structure (endogenous source dsRNA), at the cleavage site, leaving two $3^{\prime}$ overhang nucleotide and 5' phosphate group [35]. Inside the nucleus, Drosha and Pasha, in case of miRNA, are responsible for trimming the end of stem-loop like pri-miRNA, leading to the generation of pre-miRNA. Now, this pre-miRNA is transported to the cytoplasm with the help of Ran-GTP mediated exportin-5 nuclear transporter, where Dicer chops the dsRNA into mature miRNA [36]. 
Viral RNA TI | | | | | | | | | | | | | | | | | RDRP R R

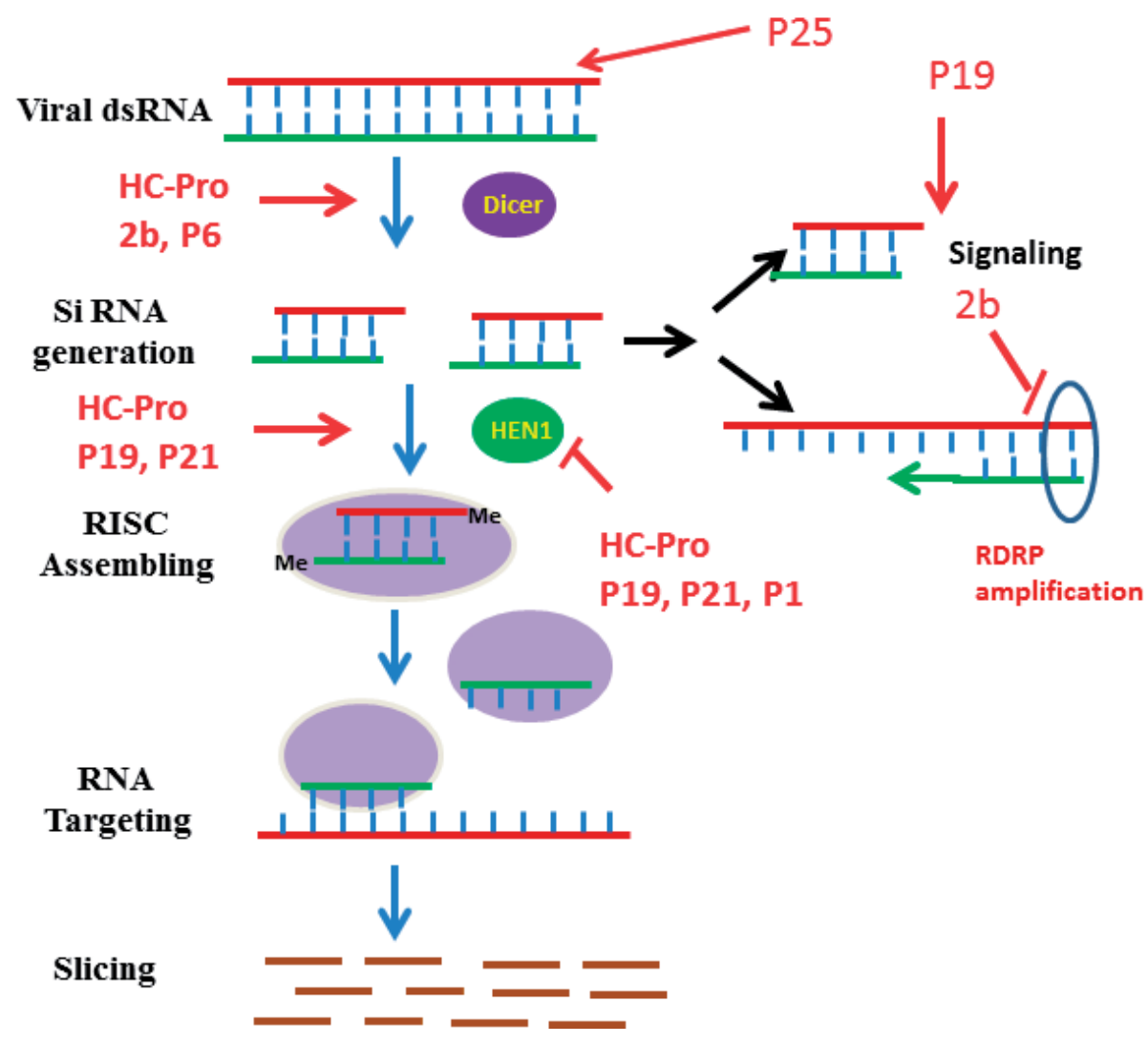

Figure 1.

Viral RNA silencing in plant and its counter defense.

Processing of exogenous RNAs is cytoplasmic that leads to the biogenesis of siRNA only requires Dicer but not Drosha. Dicer contains two RNase III domains, one helicase domain, one dsRNA binding domain, and one Piwi/Argonaute/Zwille domain. The PAZ domain known to be very essential for RNAi is also found in Argonaute family proteins. The present finding proposes that the binding of Dicer as far as possible of dsRNA is unmistakably more impressive than inner binding. Dicer will connect with a current end of dsRNA and removes $\sim 21$ nucleotides from the end, shaping another end with two $3^{\prime}$ overhangs. A pool of 21-nt-long small RNA with two 3' overhangs nucleotides will be generated from long dsRNAs, as a result of this stepwise cutting [37]. A few organisms contain more than one Dicer genes, with every Dicer specially processing dsRNAs from various sources. Arabidopsis thaliana has four Dicer-like proteins, out of which DCL-1 participates in microRNA development, DCL-2 especially processes dsRNA from plant virus and DCL-3 generates small RNAs from endogenous repeated sequences. Interestingly, only one Dicer gene is encoded by most of the mammals [38].

\subsection{Selection of siRNA strand and assembly of RISC}

The products of dsRNA and pre-siRNA processing by Dicer are 20 bp duplexes with 3' overhangs. However, functional RISCs that consist of miRNAs and siRNAs must be single stranded for matching with the target RNA. How are the duplexes changed over to single-chain structures and how is a right (e.g., antisense or 
"direct") strand chosen for stacking onto the RISC? The later inquiry is of reasonable significance in light of the fact that in order to knock down genes, artificial siRNAs can be directly used to trigger RNAi. Sequence analysis of the duplexes formed by pre-siRNA processing by Dicer and measurements of the potency of different double- and single-stranded siRNAs have demonstrated that the strand fused into the RISC is commonly the one whose $5^{\prime}$ end is the thermodynamically less steady end of the duplex [39]. Recent studies suggest that, in Drosophila, the Dcr-2-R2D2 heterodimer senses the differential stability of the duplex ends and decides which siRNA strand should get selected. Dicer binds to a less stable and R2D2 to a more stable siRNA end that is demonstrated by photocross-linking to siRNAs containing 5-iodouracils at different positions. Argonaute proteins are the most conserved members of RISC, which are essential most for RISC functions. Argonaute proteins are highly rich in basic amino acids, and in plants, these residues are basically responsible for cross-linking with the guide RNA [40]. Argonaute proteins are characterized by the presence of two homology regions, the PAZ domain and the PIWI domain (RNase $\mathrm{H}$ like functional motif). PAZ domain specifically recognizes the unique structure of two 3' nucleotides overhangs of siRNAs and also appears in Dicer proteins. In Argonaute proteins, PIWI domain recognizes $5^{\prime}$ phosphate group and therefore is required for siRNA to assembly into RISC. Endogenous kinase rapidly phosphorylates siRNA, lacking phosphate group in $5^{\prime}$ end [41]. Transfer of Dicer-processed dsRNA to RISC is mediated by several unknown proteins. RISC needs an ATP-dependent process for activation, which helps in loosening up siRNA duplex, leaving just single-stranded RNA joining the dynamic type of RISC. Near studies on solidness among functional and nonfunctional siRNA demonstrate that the $5^{\prime}$ antisense regions of the practical siRNAs were less thermodynamically stable than the $5^{\prime}$ sense districts, giving a premise to their specific passage into the RISC. Through Watson-Crick base paring, the strand remained within the RISC function as a guide to locate target mRNA sequence, while during the loading process, the other strand of duplex siRNA is either cleaved or discarded. The only member of the Argonaute subfamily of proteins, the endonuclease Argonaute 2 with observed catalytic activity in mammalian cells, is liable for this cutting action. Severed transcripts will experience resulting degradation by cell exonucleases. During this procedure, the guiding strand of siRNA duplex inside RISC will be unblemished and thusly catalytically permit RISC function. This strong cleavage pathway makes it an extremely appealing technique for decision for potential restorative utilizations of RNAi [42]. It is still a matter of debate, whether siRNA-mediated regulation has an impact on initiation, elongation, or termination or whether it acts co-translationally. For instance, human Ago2 ties to m7GTP and in this way can contend with eukaryotic translation initiation factor 4E (eIF4E) for binding to them the 7GTP-top structure of mRNA; the relationship of human Ago2 with eIF6 and large ribosomal subunits additionally recommends an early advance of translation repressed by miRNAs. In any case, miRNAs and AGOs are found to be related with polysomes, proposing that at least in some cases, inhibition occurs after initiation [24].

The majority of the miRNAs hybridize to target mRNA with a near-perfect complementarity in plants and through a similar, if not identical, mechanism used by the siRNA pathway mediate an endonucleolytic cleavage. While in animal, miRNA interacts only with 3'UTR of mRNA (For ex; lin-4) and regulated expression of proteins negatively. The focal bungle between miRNA and mRNA hybridization is accepted to be answerable for the absence of RNAi-interceded mRNA cleavage occasions (e.g., absence of RISC-intervened mRNA debasement). At long last, miRNAmRNA complex related with Ago proteins moves to processing body, where mRNA at long last is debased by RISC-free pathway $[43,44]$. RNAi that interceded the 
silencing of genes is not constrained to the posttranscriptional level as it was. SiRNA can also trigger de novo DNA methylation and transcriptional silencing; it has been shown in plants. Recent evidence suggests that in the genomes of certain species, siRNAs can inactivate transcription through direct DNA methylation and other types of covalent modification. Several studies also demonstrated that for the formation and maintenance of higher-order chromatin structure and function, RNAi machinery present in the fission yeast $S$. pombe plays a critical role. It is hypothesized that expression of centromeric repeats results in the formation of a dsRNA that is cleaved by Dicer into siRNAs that direct DNA methylation of heterochromatic sites and regulate the expression of genes $[45,46]$. Suppressors of posttranscriptional RNA silencing are encoded by many plant and some animal viruses that interfere with the accumulation or function of siRNAs. Recent crystallographic studies have revealed how the 19 suppressor protein of Tombusviridae elegantly and effectively sequesters siRNAs aimed at destroying viral RNA [47, 48].

In plant defense against pathogen invasion, RNA silencing functions as a natural immunity mechanism [49], and many viruses have evolved to express virus silencing repressor (VSR) proteins to counteract host antiviral RNA silencing. At molecular level, some of the virus-silencing repressors were studied, for example, $2 \mathrm{~b}$ of cucumber mosaic, P69 of the turnip yellow mosaic virus (TYMV), and HC-Pro of the turnip mosaic virus (TuMV), in Arabidopsis. Without a doubt, P19 protein of tombusviruses, the most popular VSR up until this point, forestalls RNA silencing by siRNA sequestration through binding ds siRNA with a high affinity [50]. Crystallographic examines have uncovered that P19 structures are a tail-to-tail homodimer, which acts like a subatomic caliper, estimating the length of siRNA duplexes and restricting them in a sequence autonomous way, choosing for the 19-bp-long dsRNA region of the common siRNA [48]. It is also confirmed through latest findings that the spread of the ds siRNA duplex hindered by P19 is recognized as the sign of RNA silencing [51].

Different VSRs, for example, the tomato aspermy cucumovirus $2 \mathrm{~b}$ protein or B2 of the insect-infecting Flock House infection, likewise tie ds siRNA in a size-explicit way; all things considered auxiliary examinations have demonstrated that their methods of binding siRNAs do not impart any closeness to P19 [52].

In agroinfiltration assays, two viral proteins that were recognized appeared to restrain the processing of dsRNA to siRNAs: P14 of Pothos latent aureusvirus and P38 of turnip crinkle virus (TCV). As of late, it was found that the activity of the P38 protein happens through AGO1 binding and that it meddles with the AGO1dependent homeostatic network, which prompts the hindrance of Arabidopsis DCLs [53]. The P6 VSR of the cauliflower mosaic virus (CaMV) studies has shown to interfere with vsiRNA processing, in addition to P14 and P38. Previously, P6 was portrayed as a viral translational trans-activator protein basic for virus biology. Critically, P6 has two importin-alpha-dependent nuclear localization signals, which are obligatory for CaMV infectivity. An ongoing disclosure demonstrated that one of the nuclear functions of P6 is to stifle RNA silencing by interacting with dsRNArestricting protein 4 , which is required for the functioning of DCL-4.

\section{Virus-induced gene silencing}

Van Kammen termed "virus-induced gene silencing” first of all to describe the phenomenon of recovery from virus infection [54]. Though, the term has since been applied almost exclusively to the technique involving recombinant viruses to knock down the expression of endogenous genes $[55,56]$. Around the world, RNA silencing has become a major focus of molecular biology and biomedical research. 
Plant biologists have adopted numerous methods to engineer resistant plants that reduce the losses caused by plant pathogens. During the last two decades, RNA silencing-based resistance has been a powerful tool that has been used to engineer resistant crops, among them. In view of this system, various methodologies were created. Virus-induced gene silencing is a virus vector technology that uses an RNA-intervened antiviral defense mechanism. In plants, infected with unmodified viruses, the system is explicitly focused against the viral genome. However, with virus vectors carrying inserts derived from host genes the process can be additionally targeted against the corresponding mRNAs. VIGS has been generally utilized in plants for investigation of gene function and has been adjusted for high-throughput functional genomics. Most uses of VIGS have been studied in Nicotiana benthami$a n a$, up to this point. In any case, in other plants including Arabidopsis, new vector systems and methods are being developed that could be used. VIGS also helps in the identification of genes required for disease resistance in plants. When VIGS is used in the analysis of other aspects of plant biology, these methods and the underlying general principles are also applied.

When a plant virus infects a host cell, it activates an RNA-based defense that is targeted against the viral genome. In the virus-infected cells, dsRNA is thought to be the replication intermediate that causes the siRNA/RNase complex to target the viral single-stranded RNA. The viral ssRNA would not be a target of the siRNA/ RNase complex in the initially infected cell because this replication intermediate would not have accumulated to a high level. However, the viral dsRNA and siRNA would become more abundant, as the rate of viral RNA replication increases in the later stages of the infection. Eventually, the viral ssRNA would be targeted intensively, and virus accumulation would slow down [57]. Many plant viruses encode proteins that are suppressors of this RNA silencing process. These suppressor proteins would not cause complete suppression of the RNA-based defense mechanism as they would not be produced until the virus had started to replicate in the infected cell. Nonetheless, these proteins would impact the final steady-state level of virus accumulation. Strong suppressors would permit virus aggregation to be drawn out and at a significant level. Alternately, if a virus gathers at a low level, it could be because of the weak suppressor activity [58]. The dsRNA replication intermediate would be prepared with the goal that the siRNA in the infected cell would compare to parts of the viral vector genome, including any nonviral insert. Thus, the siRNAs would target the RNase complex to the corresponding host mRNA, if the insert is from a host gene and the symptoms in the infected plant would reflect the loss of the function in the encoded protein.

There are a few models that strongly support this way to deal with suppression of gene expression. In this manner, when tobacco mosaic virus (TMV) or potato virus $\mathrm{X}$ (PVX) vectors were adjusted to convey inserts from the plant phytoene desaturase gene, on the infected plant the photobleaching indications reflects the non-attendance of photoprotective carotenoid pigments that require phytoene desaturase. Thus, when the virus conveys additions of a chlorophyll biosynthetic enzyme, there were chlorotic side effects, and, with a cellulose synthase insert, the infected plant had modified cell walls [59]. Genes other than those encoding metabolic catalysts can likewise be focused by VIGS. For instance, if the viral supplement related to genes is required for virus opposition, the plant showed upgraded pathogen weakness. In one such model, the supplement in a tobacco rattle virus (TRV) vector was from a gene (EDS1) that is required for $\mathrm{N}$-intervened protection from TMV. The virus vector-tainted N-genotype plant showed mediated TMV obstruction. The manifestations of a TRV vector conveying a verdant supplement show how VIGS can be utilized to target gene that directs advancement. Leafy is a gene required for bloom advancement. Loss-of-function Leafy mutants produce changed 
blossoms that are phenocopied in the TRV-leafy-infected plants. Correspondingly, the effects of tomato golden mosaic infection vectors carrying parts of the gene for a cofactor of DNA polymerase shows, how VIGS can be utilized to target essential genes. The plants infected with this geminivirus vector were suppressed for division development in and around meristematic zones of the shoot [60].

RNAi via siRNAs has generated a great deal of interest in both basic and applied biology to exploit the ability to knock down any gene of interest. There are an expanding number of large-scale RNAi screens that are intended to recognize the significant genes in different biological pathways. As the ailment forms additionally rely upon the consolidated activity of different genes, it is normal that killing the action of a gene with explicit siRNA could deliver a restorative advantage to humanity. Based on the siRNA-mediated RNA silencing (RNAi) mechanism, several transgenic plants has been designed to trigger RNA silencing by targeting pathogen genomes. Based on the difference in precursor RNA, diverse targeting approaches have been developed for siRNA creation, including sense/antisense RNA, small/long hairpin RNA, and man-made miRNA antecedents. Numerous transgenic plants have been planned by virologists, expressing viral coat protein (CP), movement protein (MP), and replication-related proteins, demonstrating to be safe against contamination by the homologous virus. This sort of pathogendetermined resistance (PDR) has been accounted for in different infections including tobamovirus, potexvirus, cucumovirus, tobravirus, Carlavirus, potyvirus, and alfalfa mosaic virus bunches just as the luteovirus gathering [49, 61]. Transgene RNA silencing-intervened resistance is a procedure that is exceptionally connected with the amassing of viral transgene-inferred siRNAs. One of the disadvantages of the sense/antisense transgene approach is that the opposition is shaky and the component regularly brings about deferred obstruction or low adequacy/resistance. This might be because of the low collections of transgene-inferred siRNA in PTGS because of the defense system encoded by plants. Additionally, various infections, including potyviruses, cucumoviruses, and tobamoviruses, can check these systems by hindering this kind of PTGS. Thusly, the rich expression of the dsRNA to trigger productive RNA silencing gets significant for viable obstruction. To accomplish opposition, inverse repeat sequences from viral genomes were broadly used to frame hairpin dsRNA in vivo, including small hairpin RNA (shRNA), self-complementary hpRNA, and intron-spliced hpRNA. Among these techniques, selfcomplementary hairpin RNAs is isolated by an intron prone to evoke PTGS with the most elevated proficiency. The nearness of modified rehashes of dsRNA-induced PTGS (IR-PTGS) in plants likewise demonstrated high resistance against viruses. For the processing of primary siRNAs, IRP-TGS is not required for the formation of dsRNA; in any case, the plant RDRs are liable for the age of secondary siRNAs got from non-transgene viral genome, which further strengthens the adequacy of RNA silencing instigated by hpRNA, a procedure named RNA silencing transitivity. Among them, the most significant are sequence closeness between the transgene sequence and the difficult virus infection arrangement. Scientists have engineered several transgenic plants with multiple hpRNA constructs from different viral sources, or with a single hpRNA construct combining different viral sequence. At the same time, various viruses can be focused on, and the subsequent transgenic plants show a more extensive resistance with high viability. Notwithstanding the arrangement closeness, the length of the transgene sequence additionally adds to high resistance. As a rule, transgene sequence with a normal length of 100-800 nt gives viable obstruction $[62,63]$.

By mimicking the unblemished secondary structure or hairpin loop of endogenous miRNA antecedents, artificial miRNAs (amiRNAs) are planned and handled 
in vivo to focus on the genes of intrigue. The technique of expressing amiRNAs was first adopted to knock down endogenous genes for functional analysis. The innovation is generally utilized in building antiviral plants and animals. Conventional with regular RNAi methodologies, amiRNAs have numerous preferences:

1. Owing to the short sequence of amiRNAs, a long viral cDNA fragment is not required; therefore, the full degree of off-target impacts are avoided, and the biosafety of transgenic crops is expanded, contrasted with siRNAs from long clip RNA.

2. Tissue- or cell-explicit take-out/downs of genes of intrigue can be acknowledged as a result of various tissue- or cell-explicit advertisers being utilized.

3. The casual interest on sequence length makes amiRNAs particularly valuable in focusing on a class of moderated genes with high succession likenesses, similar to a couple of exhibited genes, on the grounds that a short preserved grouping is all the more effectively found in these genes [64].

Viruses which have been altered and utilized for silencing the gene of intrigue are outlined in Table 1 [65-86]. Tobacco mosaic virus is one of the changed viruses which were utilized for compelling pds gene silencing in Nicotiana benthamiana plants. TMV is the main changed virus for use of VIGS techniques to plant.

Potential of VIGS for analysis of gene function was easily recognized when the viral delivery leads to downregulation of transcript of target gene through its homologydependent degradation. Tobacco rattle virus was also modified to be a tool for gene silencing in plants. Using TRV vectors, VIGS has been effectively applied in $N$. benthamiana and in tomato. The critically preferred position of TRV-based VIGS in solanaceous species is the simplicity of presentation of the VIGS vector into plants. The VIGS vector is set between right border (RB) and left border (LB) locales of T-DNA and embedded into Agrobacterium tumefaciens [81, 82].

Another property of TRV is the more vivacious spreading everywhere throughout the whole plant including meristem, and disease manifestations of TRV are gentle. Strong duplicate 35S promoter and a ribozyme at C-terminus make modified TRV vectors such as pYL156 and pYL279 more efficient and spread faster. These vectors are also able to infect other plant species. In tomato, TRV-based vector has been used [43] for gene silencing. Recently, Pflieger et al. have indicated that a viral vector got from turnip yellow mosaic virus (TYMV) can prompt VIGS in Arabidopsis thaliana. VIGS of $N$. benthamiana utilizing potato virus X (PVX) was likewise accomplished. PVX-based vectors have more limited host range (only three families of plants are susceptible to PVX) than TMV based vectors (nine plant families show susceptibility for TMV) but PVX-based vectors are more stable compared to TMV. For VIGS studies, geminivirus-inferred vectors can be utilized particularly to examine the capacity of genes associated with meristem function. Tomato golden mosaic virus (TGMV) was utilized to silence a meristematic gene, proliferating cell nuclear antigen (PCNA) in $N$. benthamiana. The TGMV-based silencing vector had been utilized for likewise silencing of non-meristematic gene silencing. In plants, only with the help of other helper viruses for efficient gene silencing, satellite virus-based vectors are also used. This two-component system is called satellite virus-induced silencing system (SVISS) [60, 87]. Previously, barley stripe mosaic virus (BSMV) was developed for efficient silencing of $p d s$ gene, in barley. Then, this system was used for silencing of wheat genes. BSMV is a positive-sense RNA virus containing a tripartite $(\alpha, \beta, \gamma)$ genome. The modified $\gamma$ of BSMV genome was used for plant 


\begin{tabular}{|c|c|c|c|c|c|}
\hline Virus/type & Group & Natural hosts & $\begin{array}{l}\text { Silenced host } \\
\text { species }\end{array}$ & $\begin{array}{l}\text { Gene } \\
\text { silenced }\end{array}$ & References \\
\hline $\begin{array}{l}\text { African } \\
\text { cassava } \\
\text { mosaic virus, } \\
\text { DNA virus, } \\
\text { bipartite }\end{array}$ & Begomovirus & $\begin{array}{l}\text { Manihot } \\
\text { esculenta }\end{array}$ & $\begin{array}{l}\text { N. benthamiana, } \\
\text { M. esculenta }\end{array}$ & $\begin{array}{l}\text { pds, su, } \\
\text { cyp79d2 }\end{array}$ & {$[65]$} \\
\hline $\begin{array}{l}\text { Apple latent } \\
\text { spherical } \\
\text { virus } \\
\text { RNA virus, } \\
\text { bipartite }\end{array}$ & Cheravirus & Apple & $\begin{array}{l}\text { N. tabacum, } \\
\text { N. occidentalis, } \\
\text { N. benthamiana, } \\
\text { N. glutinosa, } \\
\text { Solanum } \\
\text { lycopersicon, } \\
\text { A. thaliana } \\
\text { Cucurbit species, } \\
\text { several legume } \\
\text { species }\end{array}$ & $\begin{array}{l}\text { pds, su, } \\
\text { pcna }\end{array}$ & {$[66]$} \\
\hline $\begin{array}{l}\text { Barley stripe } \\
\text { mosaic virus } \\
\text { RNA virus, } \\
\text { tripartite }\end{array}$ & Hordeivirus & $\begin{array}{l}\text { Barley, wheat, } \\
\text { oat, maize, } \\
\text { spinach }\end{array}$ & $\begin{array}{l}\text { Hordeum vulgare, } \\
\text { Triticum aestivum }\end{array}$ & $\begin{array}{l}\text { Pds, } \\
\text { TaEra1 }\end{array}$ & {$[67,68]$} \\
\hline $\begin{array}{l}\text { Bean pod } \\
\text { mottle virus } \\
\text { RNA virus, } \\
\text { bipartite }\end{array}$ & Cucumovirus & $\begin{array}{l}\text { Phaseolus } \\
\text { vulgaris, } \\
\text { Glycine max }\end{array}$ & G. $\max$ & $\begin{array}{l}P d s, \\
G m R P A 3\end{array}$ & {$[69,70]$} \\
\hline $\begin{array}{l}\text { Brome } \\
\text { mosaic virus } \\
\text { RNA virus, } \\
\text { tripartite }\end{array}$ & Bromovirus & Barley & $\begin{array}{l}\text { Hordeum vulgare, } \\
\text { Oryza sativa, and } \\
\text { Zea mays }\end{array}$ & $\begin{array}{l}\text { pds, actin } \\
1, \text { rubisco } \\
\text { activase }\end{array}$ & {$[71]$} \\
\hline $\begin{array}{l}\text { Cabbage leaf } \\
\text { curl virus } \\
\text { DNA virus, } \\
\text { bipartite }\end{array}$ & Begomovirus & $\begin{array}{l}\text { Cabbage, } \\
\text { broccoli, } \\
\text { cauliflower }\end{array}$ & A. thaliana & $\begin{array}{l}g f p \\
\text { CH42, } \\
p d s\end{array}$ & [72] \\
\hline $\begin{array}{l}\text { Cucumber } \\
\text { mosaic virus } \\
\text { RNA virus, } \\
\text { tripartite }\end{array}$ & Cucumovirus & $\begin{array}{l}\text { Cucurbits, } S \text {. } \\
\text { lycopersicon, } \\
\text { Spinacia } \\
\text { oleracea }\end{array}$ & G. $\max$ & $\begin{array}{l}\text { chs, } \\
s f 30 h 1\end{array}$ & [73] \\
\hline $\begin{array}{l}\text { Pea early } \\
\text { browning } \\
\text { virus, } \\
\text { RNA virus, } \\
\text { Bipartite }\end{array}$ & Tobravirus & $\begin{array}{l}\text { Pisum sativum, } \\
\text { Phaseolus } \\
\text { vulgaris }\end{array}$ & P. sativum & $\begin{array}{l}\text { pds, uni, } \\
\text { kor }\end{array}$ & [74] \\
\hline $\begin{array}{l}\text { Poplar } \\
\text { mosaic virus } \\
\text { RNA virus, } \\
\text { monopartite }\end{array}$ & Carlavirus & Poplar & N. benthamiana & $g f p$ & [75] \\
\hline $\begin{array}{l}\text { Potato virus } \\
\text { X } \\
\text { RNA virus, } \\
\text { monopartite }\end{array}$ & Potexvirus & $\begin{array}{l}\text { Solanum } \\
\text { tuberosum, } \\
\text { Brassica } \\
\text { campestris ssp. } \\
\text { rapa }\end{array}$ & $\begin{array}{l}\text { N. benthamiana, } \\
\text { A. thaliana }\end{array}$ & $\begin{array}{l}\text { gus, pds, } \\
\text { DWARF, } \\
S S U, \\
N F L, \\
L F Y\end{array}$ & {$[76]$} \\
\hline $\begin{array}{l}\text { Satellite } \\
\text { tobacco } \\
\text { mosaic virus } \\
\text { RNA virus, } \\
\text { satellite }\end{array}$ & $\begin{array}{l}\text { RNA satellite } \\
\text { virus }\end{array}$ & $\begin{array}{l}\text { Nicotiana } \\
\text { glauca }\end{array}$ & N. tabacum & $\begin{array}{l}\text { Several } \\
\text { genes }\end{array}$ & [77] \\
\hline
\end{tabular}




\begin{tabular}{|c|c|c|c|c|c|}
\hline Virus/type & Group & Natural hosts & $\begin{array}{l}\text { Silenced host } \\
\text { species }\end{array}$ & $\begin{array}{l}\text { Gene } \\
\text { silenced }\end{array}$ & References \\
\hline $\begin{array}{l}\text { Tomato } \\
\text { bushy stunt } \\
\text { virus, RNA } \\
\text { virus }\end{array}$ & Tombusvirus & $\begin{array}{l}\text { S. lycopersicon, } \\
\text { N. benthamiana }\end{array}$ & N. benthamiana & $g f p$ & [78] \\
\hline $\begin{array}{l}\text { Tobacco } \\
\text { curly shoot } \\
\text { virus, DNA } \\
\text { satellite-like } \\
\text { virus }\end{array}$ & $\begin{array}{l}\text { DNA } \\
\text { satellite-like } \\
\text { virus }\end{array}$ & N. tabacum & $\begin{array}{l}\text { N. tabacum, } \\
\text { Solanum } \\
\text { lycopersicon, } \\
\text { Petunia hybrida, } \\
\text { N. benthamiana }\end{array}$ & $\begin{array}{l}g f p, s u, \\
c h s, p c n a\end{array}$ & [79] \\
\hline $\begin{array}{l}\text { Tobacco } \\
\text { mosaic virus } \\
\text { RNA virus, } \\
\text { monopartite }\end{array}$ & Tobamovirus & N. tabacum & $\begin{array}{l}\text { N. benthamiana, } \\
\text { N. tabacum }\end{array}$ & $p d s, p s y$ & {$[80]$} \\
\hline $\begin{array}{l}\text { Tobacco } \\
\text { rattle virus } \\
\text { RNA virus, } \\
\text { bipartite }\end{array}$ & Tobravirus & $\begin{array}{l}\text { Wide host } \\
\text { range }\end{array}$ & $\begin{array}{l}\text { N. benthamiana, } \\
\text { A. thaliana, } S . \\
\text { lycopersicon }\end{array}$ & $\begin{array}{l}p d s, r b c S, \\
F L O / L F Y \\
(N F L) \\
\text { Sllea4 }\end{array}$ & {$[81,82,83]$} \\
\hline $\begin{array}{l}\text { Tomato } \\
\text { golden } \\
\text { mosaic virus, } \\
\text { DNA virus, } \\
\text { bipartite }\end{array}$ & Begomovirus & S. lycopersicon & N. benthamiana & su, luc & {$[84]$} \\
\hline $\begin{array}{l}\text { Tomato } \\
\text { yellow leaf } \\
\text { curl China, } \\
\text { DNA satellite }\end{array}$ & Begomovirus & S. lycopersicon & $\begin{array}{l}\text { N. benthamiana, } \\
\text { S. lycopersicon, } \\
\text { N. glutinosa, } \\
\text { N. tabacum }\end{array}$ & $\begin{array}{l}\text { pcna, pds, } \\
s u, g f p\end{array}$ & [85] \\
\hline $\begin{array}{l}\text { Turnip } \\
\text { yellow } \\
\text { mosaic virus, } \\
\text { RNA virus, } \\
\text { monopartite }\end{array}$ & Tymovirus & Brassicaceae & A. thaliana & $p d s$, lfy & {$[86]$} \\
\hline
\end{tabular}

Table 1.

Plant viruses used as VIGS vectors, the nature of their genomes, and their important hosts.

gene cloning replaced by DNA vector. For defect of viral coat protein production, $\beta$ genome has been deleted. Every one of the altered DNAs is utilized to blend RNAs by in vitro transcription. As of late, Brome mosaic virus strain has been adjusted for VIGS of pds, actin, and rubisco activase. These genes were additionally silenced in significant model plants, for example, rice. Conventions for VIGS are as follows:

\subsection{Target sequence determination}

siRNA-Finder (si-Fi; http://labtools.ipk-gatersleben.de/) software that are predicted to produce high numbers of silencing effective siRNAs could be used to select 250-400 nt sequence regions. Whenever the situation allows, select at any rate two preferably non-overlapping regions of the gene of enthusiasm for VIGS investigations. Perception of a similar phenotype initiated by silencing utilizing every one of the at least two free VIGS constructs is a decent sign that the phenotype is because of explicit silencing of the expected target gene, in this manner permitting more noteworthy trust in the acquired outcomes. When endeavoring to silence, an individual from a gene family considers choosing the sequences from the 
30 or 50 UTR regions, which are commonly more factor than the CDS. This ought to limit the danger of off-target silencing. Then again, in cases among different gene family members, when a great deal of functional redundancy is expected, it should be possible to design VIGS construct(s) from the conserved gene regions in order to target several or even all gene family members simultaneously. Regarding VIGS experimental design, VIGS construct containing a 250-400 nt fragment of a non-plant origin gene, such as the Aequorea victoria Green Fluorescent Protein gene or the Escherichia coli $\beta$-glucuronidase gene, should be included as at least one negative control.

\subsection{VIGS construct formation}

Clone the VIGS target sequences into the, for instance, BSMV RNAc vector pCa-cbLIC by means of ligation-independent cloning (LIC), in either sense or antisense direction. Antisense constructs might be progressively effective in initiating gene silencing. Changed sequence checked pCa-cbLIC VIGS construct into $A$. tumefaciens GV3101 by electroporation. For this, MicroPulser (Bio-Rad) electroporator, $0.1 \mathrm{~cm}$ gap electroporation cuvettes, and home-made electro-competent cells could be utilized. Agrobacterium cultures developed to a last OD600 of 1.2, and the cells will be pelleted by centrifugation and washed in ice-cold sterile $10 \%$ glycerol in complete multiple times. Electroporation should be possible, utilizing the producer's pre-set conditions for Agrobacterium, for example, one $2.2 \mathrm{kV}$ pulse. Plate an aliquot of the transformation mixture on LB agar enhanced with $25 \mu \mathrm{g} /$ $\mathrm{ml}$ gentamycin and $50 \mu \mathrm{g} / \mathrm{ml}$ kanamycin. As BSMV requires every one of the three genomic fragments, RNAa, RNAb, and RNAc, for effective infection, it is additionally important to deliver $A$. tumefaciens GV3101 strains containing pCaBS- $\alpha$ (BSMV $\mathrm{RNA} \alpha)$ and $\mathrm{pCaBS}-\beta$ (BSMV RNA $\beta)$.

\subsection{Preparation of virus inoculum and infecting target plants with engineered virus}

Engineered virus introduced into the leaf of dicot plants (for example well studied Nicotiana benthamiana) by means of agroinfiltration. For N. benthamiana agroinfiltration, grow $5 \mathrm{ml}$ cultures (LB enhanced with $25 \mu \mathrm{g} / \mathrm{ml}$ gentamycin and $50 \mu \mathrm{g} / \mathrm{ml}$ kanamycin) of $A$. tumefaciens strains conveying pCa-cbLIC VIGS constructs overnight at $28^{\circ} \mathrm{C}$ with steady shaking at $220 \mathrm{rpm}$. For each BSMV RNAc build, BSMV RNA $\alpha$ and RNA $\beta$ developed in $5 \mathrm{ml}$ cultures will likewise be required. Pellet the A. tumefaciens cells at $2500 \mathrm{rcf}$ for $20 \mathrm{~min}$, resuspend it in infiltration buffer [10 mM MgCl2, $10 \mathrm{mM}$ 2-(N-morpholino)-ethanesulfonic acid (MES) pH 5.6, and $150 \mu \mathrm{M}$ acetosyringone] to a last optical density at $600 \mathrm{~nm}$ (OD600), and incubate it at room temperature without shaking for $3 \mathrm{~h}$ or more. Blend A. tumefaciens strains conveying BSMV RNA $\alpha$, RNA $\beta$, and RNA $\gamma$ strains together in a 1:1:1 proportion, and pressure infiltrate the bacteria into the abaxial side of completely extended leaves of roughly 25-30-day-old $N$. benthamiana plants utilizing a needleless $1 \mathrm{ml}$ syringe. Utilize $0.5-1 \mathrm{ml}$ of Agrobacterium suspension per leaf and mean to penetrate the entire zone of each leaf.

\subsection{Assessment of virus-induced gene silencing}

Quantitative reverse transcription PCR (qRT-PCR) is used for the assessment of successful silencing of the target gene in the VIGS construct-infected plants. The primers utilized for this reason should tie outside the region focused for silencing. 


\subsection{Viral infection to the plant and disease evaluation}

In the wake of affirming the killing of target gene, one needs to infect the host (plant) from the susceptible virus for the disease appraisal. Genes were focused on that delivered unmistakable phenotypes, for example, silencing of GFP in transgenic tobacco communicating GFP, the photobleaching of leaves brought about by lost carotenoid pigments when phytoene desaturase (pds) was disturbed [56]. Different models focused on the chlorophyll biosynthetic enzyme, bringing about plant chlorosis [59], and the cellulose synthase gene, bringing about a change of plant cell dividers. With the underlying accomplishment of VIGS, specialists started focusing on basic genes [60], for example, those engaged with plant resistance [60] encoding metabolic enzymes, expanding crop yield, or plant development and advancement. For instance, when a VIGS vector developed with tobacco rattle virus was adjusted with the EDS1 gene required for $\mathrm{N}$-intervened resistance from TMV, the immunized plants had an improved susceptibility to TRV.

\section{Next-generation VIGS with CRISPR/Cas system}

In plant biology, virus-induced gene silencing has made a tremendous impact by silencing and then identifying endogenous genes. However, it is now possible for targeted genome editing and precise knocking out of entire genes with one of the most recent and promising genetic tools, the CRISPR/Cas DNA system. In ongoing investigations, CRISPR/Cas9 was utilized to alter plant genomes, for example, rice, $N$. benthamiana and Arabidopsis for heritable changes. The method is basic and requires just transgenic plants expressing cas9 and guide RNA. (The specialized terms are clarified beneath.) Moreover, the hereditary changes are available in ensuing ages. The VIGS system, other than its capacity to silence genes, has discovered a significant application in the CRISPR/Cas altering system. It very well may be utilized as a vehicle to ship the CRISPR/Cas altering system into plant system.

In spite of the fact that this innovation is new, various evidence of idea concentrates in model plants have indicated its potential as a gene editing technology. The productivity, precision, and adaptability of the CRISPR/Cas9 genome engineering system have been exhibited in different eukaryotes, for example, yeast, zebrafish, and worms. The potential applications have been developing quickly which incorporate the forefront use of gene altering in the germlines of people and different life forms. This technique was as of late received in plant systems in different transient tests or in transgenic plants and is turning into the strategy for decision for plant researchers.

Like RNA interference, the CRISPR/Cas gene altering innovation was gotten from a normally happening plant protection mechanism. It gives a type of acquired immunity to the cleavage of DNA present in specific prokaryotes and gives obstruction against foreign hereditary components, for example, phages and plasmids. It depends on the type II clustered regulatory interspaced short palindromic repeats (CRISPR). CRISPR is a sequence of short, monotonous portions followed by a short fragment of spacer DNA. The spacer DNA could be from past exposures to a virus, plasmid, or bacterium. A proof that the wellspring of the spacers was a bacterial genome was the principal trace of the CRISPR's job in an adaptive immunity equivalent to RNA interference. It was before long recommended that the spacers recognized in bacterial genomes filled in as templates for RNA molecules that the bacteria transcribed following a presentation to an attacking phage. Further examinations uncovered that a significant protein called Cas9 was included, together with the transcribed RNA, to perceive the attacking phage and cut the RNA into small 
pieces (crRNA) in the CRISPR system. CRISPRs are found in practically $90 \%$ of the sequenced Archaea and up to $40 \%$ of bacterial genomes. Local bacterial CRISPR RNAs likewise can be adjusted into a single gene known as a single guide RNA (sgRNA). Utilizing sgRNA, the system has gotten increasingly adaptable, permitting it to streamline genome altering by consolidating sgRNA and Cas9 out of a heterologous framework. In plants, the CRISPR/Cas9 system utilizes the two segments; the Cas9 compound catalyzes DNA cleavage and the sgRNA initiates Cas9 to the objective site. This site is generally situated around 20 nucleotides before the protospacer theme and cuts the DNA. Plants utilize the natural mechanism, to reattach the cleaved ends of DNA called nonhomologous end joining [37] and typically bring about a change either by frameshift, addition/erasure, or inclusion of a stop codon. Hence, by essentially designing a sgRNA with a corresponding sequence, for all intents and purposes, any gene can be altered with this heterologous system.

\section{Author details}

Jitesh Kumar $^{1}$, Khushbu Jain ${ }^{3}$, Priyanka Kumari ${ }^{1}$, Auroshikha Mohanty ${ }^{1}$, Kumari Rajani ${ }^{2}$, Ravi Ranjan Kumar $^{1}$ and Tushar Ranjan ${ }^{1 *}$

1 Department of Molecular Biology and Genetic Engineering, Bihar Agricultural University, Bhagalpur, Bihar, India

2 Department of Seed Science and Technology, Bihar Agricultural University, Bhagalpur, Bihar, India

3 Department of Plant Breeding and Genetics, Bihar Agricultural University, Bhagalpur, Bihar, India

*Address all correspondence to: mail2tusharranjan@gmail.com

\section{IntechOpen}

(C) 2020 The Author(s). Licensee IntechOpen. This chapter is distributed under the terms of the Creative Commons Attribution License (http://creativecommons.org/licenses/ by/3.0), which permits unrestricted use, distribution, and reproduction in any medium, provided the original work is properly cited. (cc) BY 


\section{References}

[1] Napoli C, Lemieux C, Jorgensen R. Introduction of a chimeric chalcone synthase gene into petunia results in reversible co-suppression of homologous genes in trans. The Plant Cell. 1990;2(4):279-289

[2] Ecker JR, Davis RW. Inhibition of gene expression in plant cells by expression of antisense RNA. Proceedings of the National Academy of Sciences of the United States of America. 1986;83(15):5372-5376

[3] Romano N, Macino G. Quelling: transient inactivation of gene expression in Neurospora crassa by transformation with homologous sequences. Molecular Microbiology. 1992;6(22):3343-3353

[4] Van Blokland R, Vander Geest N, Mol JNM, Kooter JM. Transgenemediated suppression of chalcone synthase expression in Petunia hybrida results from an increase in RNA turnover. The Plant Journal. 1994;6(6):861-877

[5] Covey S, Al-Kaff N, Lángara A, Turner D. Plants combat infection by gene silencing. Nature. 1997;385(6619):781-782

[6] Ratcliff F, Harrison B, Baulcombe D. A similarity between viral defense and gene silencing in plants. Science. 1997;276(5318):1558-1560

[7] Fire A, Xu S, Montgomery MK, Kostas SA, Driver SE, Mello CC. Potent and specific genetic interference by double-stranded RNA in Caenorhabditis elegans. Nature. 1998;391(6669):806-811

[8] Guo S, Kemphues K. par-1, a gene required for establishing polarity in C. elegans embryos, encodes a putative Ser/Thr kinase that is asymmetrically distributed. Cell. 1995;81(4):611-620
[9] Pal-Bhadra M, Bhadra U, Birchler J. Cosuppression in Drosophila: gene silencing of alcohol dehydrogenase by white-Adh transgenes is polycomb dependent. Cell. 1997;90(3):479-490

[10] Tabara H, Sarkissian M, Kelly WG, Fleenor J, Grishok A, Timmons L, et al. The rde-1 gene, RNA interference, and transposon silencing in C. elegans. Cell. 1999;99(2):123-132

[11] Hamilton AJ, Baulcombe DC. A species of small antisense RNA in posttranscriptional gene silencing in plants. Science. 1999;286(5441):950-952

[12] Hammond SM, Bernstein E, Beach D, Hannon GJ. An RNA-directed nuclease mediates post-transcriptional gene silencing in Drosophila cells. Nature. 2000;404(6775):293-296

[13] Zamore PD, Tuschl T, Sharp PA, Bartel DP. RNAi: double-stranded RNA directs the ATP dependent cleavage of mRNA at 21 to 23 nucleotide intervals. Cell. 2000;101(1):25-33

[14] Tomari Y, Zamore PD. Perspective: Machines for RNAi. Genes \& Development. 2005;19:517-529

[15] Meister G, Landthaler M, Patkaniowska A, Yair D, Teng G, Tuschl T. Human argonaute2 mediates RNA cleavage targeted by miRNAs and siRNAs. Molecular Cell. 2004;15(2):185-197

[16] Cenik ES, Fukunaga R, Lu G, Dutcher R, Wang Y, Tanaka Hall TM, et al. Phosphate and R2D2 restrict the substrate specificity of Dicer-2, an ATPdriven ribonuclease. Molecular Cell. 2011;42(2):172-184

[17] Zhang H, Kolb F, Jaskiewicz L, Westhof E, Filipowicz W. Single processing center models for human Dicer and bacterial RNase III. Cell. 2004;118:57-68 
[18] Macrae IJ, Zhou K, Li F, Repic A, Brooks AN, Cande WZ, et al.

Structural basis for double-stranded RNA processing by Dicer. Science. 2006;311(5758):195-198

[19] Höck J, Weinmann L, Ender C, Rüdel S, Kremmer E, Raabe M, et al. Proteomic and functional analysis of Argonaute-containing mRNA-protein complexes in human cells. EMBO Reports. 2007;8(11):1052-1060

[20] Martinez J, Patkaniowska A, Urlaub H, Lührmann R, Tuschl T. Singlestranded antisense siRNAs guide target RNA cleavage in RNAi. Cell. 2002;110(5):563-574

[21] Pham JW, Pellino JL, Lee YS, Carthew RW, Sontheimer EJ. A dicer-2dependent 80s complex cleaves targeted mRNAs during RNAi in Drosophila. Cell. 2004;117(1):83-94

[22] Gregory RI, Chendrimada TP, Cooch N, Shiekhattar R. Human RISC couples microRNA biogenesis and posttranscriptional gene silencing. Cell. 2005;123:631-640

[23] Rivas FV, Tolia NH, Song JJ, Aragon JP, Liu J, Hannon GJ, et al. Purified Argonaute 2 and an siRNA form recombinant human RISC. Nature Structural \& Molecular Biology. 2005;12(4):340-349

[24] Vaucheret H. Plant argonautes. Trends in Plant Science. 2008;13(7):350-358

[25] Grishok A, Pasquinelli AE, Conte D, Li N, Parrish S, Ha I, et al. Genes and mechanisms related to RNA interference regulate expression of the small temporal RNAs that control C. elegans developmental timing. Cell. 2001;106(1):23-34

[26] Hutvagner G, Simard MJ. Argonaute proteins: Key players in RNA silencing.
Nature Reviews. Molecular Cell Biology. 2008;9(1):22-32

[27] Yigit E, Batista PJ, Bei Y, Pang KM, Chen CC, Tolia NH, et al. Analysis of the $C$. elegans Argonaute family reveals that distinct Argonautes act sequentially during RNAi. Cell. 2006;127:747-757

[28] Meins F, Si-Ammour A, Blevins T. RNA silencing systems and their relevance to plant development. Annual Review of Cell and Developmental Biology. 2005;21(1):297-318

[29] Aravin AA, Hannon GJ, Brennecke J. The Piwi-piRNA pathway provides an adaptive defense in the transposon arms race. Science. 2007;318:761-764

[30] Brennecke J, Malone CD, Aravin AA, Sachidanandam R, Stark A, Hannon GJ. An epigenetic role for maternally inherited piRNAs in transposon silencing. Science. 2008;322:1387-1392

[31] Tang G. siRNA and miRNA: An insight into RISCs. Trends in Biochemical Sciences. 2005;30(2):106-114

[32] Richard WC, Sontheimer EJ. Origins and Mechanisms of miRNAs and siRNAs. Cell. 2009;136(4):642-655

[33] Filipowicz W, Jaskiewicz L, Kolb FA, Pillai SR. Post-transcriptional gene silencing by siRNAs and miRNAs. Current Opinion in Structural Biology. 2005;15:331-341

[34] Ranjan T, Kumari N, Sahni S, Prasad BD. RNA interference: A versatile tool for functional genomics and unraveling the genes required for viral disease resistance in plants. Current Journal of Applied Science and Technology. 2019;35(5):1-20

[35] Hannon GJ, Rossi JJ. Unlocking the potential of the human genome 
with RNA interference. Nature. 2004;431(7006):371-378

[36] Lund E, Güttinger S, Calado A, Dahlberg JE, Kutay U. Nuclear export of microRNA precursors. Science. 2004;303(5654):95-98

[37] Hammond SM. Dicing and slicing: The core machinery of the RNA interference pathway. FEBS Letters. 2005;579(26):5822-5829

[38] Xie Z, Johansen LK, Gustafson AM, Kasschau KD, Lellis AD, Zilberman D, et al. Genetic and functional diversification of small RNA pathways in plants. PLoS Biology. 2004;2(5):E104

[39] Khvorova A, Reynolds A, Jayasena SD. Functional siRNAs and miRNAs exhibit strand bias. Cell. 2003;115:209-216

[40] Tomari Y, Matranga C, Haley B, Martinez N, Zamore PD. A protein sensor for siRNA asymmetry. Science. 2004;306:1377-1380

[41] Nykanen A, Haley B, Zamore PD. ATP requirements and small interfering RNA structure in the RNA interference pathway. Cell. 2001;107(3):309-321

[42] Elbashir SM, Lendeckel W, Tuschl T. RNA interference is mediated by 21- and 22-nucleotide RNAs. Genes \& Development. 2001;15(2):188-200

[43] Liu J, Valencia-Sanchez MA, Hannon GJ, Parker R. MicroRNAdependent localization of targeted mRNAs to mammalian P-bodies. Nature Cell Biology. 2005;7(7):719-723

[44] Sen GL, Blau HM. Argonaute 2/ RISC resides in sites of mammalian mRNA decay known as cytoplasmic bodies. Nature Cell Biology. 2005;7(6):633-636

[45] Mette MF, Aufsatz W, VanderWinden J, Matzke MA, Matzke AJ.
Transcriptional silencing and promoter methylation triggered by doublestranded RNA. The EMBO Journal. 2000;19(19):5194-5201

[46] Wassenegger M, Heimes S, Riedel L, Sänger HL. RNA-directed de novo methylation of genomic sequences in plants. Cell. 1994;76(3):567-576

[47] Baulcombe D. RNA silencing in plants. Nature. 2004;431:356-363

[48] Vargason JM, Szittya G, Burgyan J, Tanaka HTM. Size selective recognition of siRNA by an RNA silencing suppressor. Cell. 2003;115:799-811

[49] Ding SW. RNA-based antiviral immunity. Nature Reviews.

Immunology. 2010;10:632-644

[50] Silhavy D, Molnár A, Lucioli A, Szittya G, Hornyik C, Tavazza M, et al. A viral protein suppresses RNA silencing and binds silencinggenerated, 21- to 25-nucleotide doublestranded RNAs. The EMBO Journal. 2002;21:3070-3080

[51] Dunoyer P, Brosnan CA, Schott G, Wang Y, Jay F, Alioua A, et al. An endogenous, systemic RNAi pathway in plants. The EMBO Journal. 2010;29:1699-1712

[52] Chen HY, Yang J, Lin C, Yuan YA. Structural basis for RNA-silencing suppression by Tomato aspermy virus protein $2 \mathrm{~b}$. EMBO Reports. 2008;9:754-760

[53] Azevedo J, Garcia D, Pontier D, Ohnesorge S, Yu A, Garcia S, et al. Argonaute quenching and global changes in Dicer homeostasis caused by a pathogen-encoded GW repeat protein. Genes \& Development. 2010;24:904-915

[54] van Kammen A. Virus-induced gene silencing in infected and transgenic 
plants. Trends in Plant Science. 1997;2:409-411

[55] Baulcombe D. Fast forward genetics based on virusinduced gene silencing. Current Opinion in Plant Biology. 1999;2:109-113

[56] Ruiz MT, Voinnet O, Baulcombe DC. Initiation and maintenance of virus-induced gene silencing. The Plant Cell. 1998;10:937-946

[57] Voinnet O. RNA silencing as a plant immune system against viruses. Trends in Genetics. 2001;17(8):449-459

[58] Brigneti G, Voinnet O, Li WX, Ji L, Ding SW, Baulcombe DC. Viral pathogenicity determinants are suppressors of transgene silencing in Nicotiana benthamiana. The EMBO Journal. 1998;17(22):6739-6746

[59] Kjemtrup S, Sampson KS, Peele CG, Nguyen LV, Conkling MV, Thompson WF, et al. Gene silencing from plant DNA carried by a Geminivirus. The Plant Journal. 1998:91-100

[60] Peele C, Jordan CV, Muangsan N, Turnage M, Egelkrout E, Eagle P, et al. Silencing of a meristematic gene using geminivirus-derived vectors. The Plant Journal. 2001;24:357-366

[61] Abel PP, Nelson RS, De B, Hoffmann N, Rogers SG, Fraley RT, et al. Delay of disease development in transgenic plants that express the tobacco mosaic virus coat protein gene. Science. 1986;232:738-743

[62] Bucher E, Lohuis D, van Poppel PM, Geerts-Dimitriadou C, Goldbach R, Prins M. Multiple virus resistance at a high frequency using a single transgene construct. The Journal of General Virology. 2006;87:3697-3701
[63] Himber C, Dunoyer P, Moissiard G, Ritzenthaler C, Voinnet O.

Transitivitydependent and-independent cell-to-cell movement of RNA silencing. The EMBO Journal. 2003;22:4523-4533

[64] Schwab R. Highly specific gene silencing by artificial microRNAs in Arabidopsis. Plant Cell.

2006;18:1121-1133

[65] Fofana IB, Sangare A, Collier R, Taylor C, Fauquet CM. A geminivirus-induced gene silencing system for gene function validation in cassava. Plant Molecular Biology. 2004;56:613-624

[66] IIgarashi AK, Kousuke Y, Tomokazu S, Yukari T, Emiko S, Aihiro T, et al. Apple latent spherical virus vectors for reliable and effective virus-induced gene silencing among a broad range of plants including tobacco, tomato, Arabidopsis thaliana, cucurbits, and legume. Virology. 2009;386(2):407-416

[67] Holzberg S, Brosio P, Gross C, Pogue GP. Barley stripe mosaic virusinduced gene silencing in a monocot plant. The Plant Journal. 2002;30(3):315-327

[68] Manmathan H, Shaner D, Snelling J, Tisserat N, Lapitan N. Virus-induced gene silencing of Arabidopsis thaliana gene homologues in wheat identifies genes conferring improved drought tolerance. Journal of Experimental Botany. 2013;64(5):1381-1392

[69] Atwood SE, O’Rourke JA, Gregory AP, Yin T, Majumder M, Zhang C, et al. Replication protein A subunit 3 and the iron efficiency response in soybean. Plant, Cell and Environment. 2014;37:213-234

[70] Zhang C, Ghabrial SA. Development of bean pod mottle virus-based vectors for stable protein expression and sequence-specific 
virus-induced gene silencing in soybean. Virology. 2006;344(2):401-411

[71] Ding XS, Schneider WL, Chaluvadi SR, Rouf Mian MA, Nelson RS. Characterization of a brome mosaic virus strain and its use as a vector for gene silencing in monocotyledonous hosts. The American Phytopathological Society MPMI. 2006;19(11):1229-1239

[72] Turnage MA, Muangsan N, Peele CG, Robertson D. Geminivirusbased vectors for gene silencing in Arabidopsis. The Plant Journal. 2002;30(1):107-114

[73] Nagamatsu A, Masuta C, Senda M, Matsuura H, Kasai A, Hong JS, et al. Functional analysis of soybean genes involved in flavonoid biosynthesis by virus-induced gene silencing. Plant Biotechnology Journal. 2007;5:778-779

[74] Constantin GD, Krath BN, MacFarlane SA, Nicolaisen M, Johansen IE, Lund OS. Virus-induced gene silencing as a tool for functional genomics in a legume species. The Plant Journal. 2004;40:622-631

[75] Naylor M, Reeves J, Cooper JI, Edwards ML, Wang H. Construction and properties of a gene-silencing vector based on poplar mosaic virus (genus Carlavirus). Journal of Virological Methods. 2005;124(1-2):27-36

[76] Ruiz MT, Voinnet O, Baulcombe DC. Initiation and maintenance of virus-induced gene silencing. The Plant Cell. 1998;10:937-946

[77] Gossele V, Fache I, Meulewaeter F, Cornelissen M, Metzlaff M. SVISS - A novel transient gene silencing system for gene function discovery and validation in tobacco plants. The Plant Journal. 2002;32:859-886
[78] Hou H, Oiu W. A novel co-delivery system consisting of a tomato bushy stunt virus and a defective interfering RNA for studying gene silencing. Journal of Virological Methods. 2003;111(1):37-42

[79] Huang YH, Baoa Y, Penga W, Goldbergb M, Loveb K, Bumcrotc DA, et al. Claudin-3 gene silencing with siRNA suppresses ovarian tumor growth and metastasis. PNAS. 2009;106(9):3426-3430

[80] Kumagai MH, Donson J, Della-Cioppa G, Harvey D, Hanley K, Grill AND, et al. Cytoplasmic inhibition of carotenoid biosynthesis with virus-derived RNA. Proceedings of the National Academy of Sciences of the United States of America. 1995;92:1679-1683

[81] Liu Y, Schiff M, DineshKumar SP. Virus-induced gene silencing in tomato. The Plant Journal. 2002;31(6):777-786

[82] Ratcliff F, Martin-Hernandez AM, Baulcombe DC. Tobacco rattle virus as a vector for analysis of gene function by silencing. The Plant Journal. 2001;25(2):237-245

[83] Senthil-Kumar M, Udaykumar M. High-throughput virus-induced genesilencing approach to assess the functional relevance of a moisture stress-induced cDNA homologous to lea4. Journal of Experimental Botany. 2006;57(10):2291-2302

[84] Peele C, Jordan CV, Muangsan N, Turnage M, Egelkrout E, Eagle P, et al. Silencing of a meristematic gene using geminivirus-derived vectors. The Plant Journal. 2001;27(4):357-366

[85] Tao X, Zhou X, Cui X, Qian Y. Virus induced gene silencing and its application for analysis of genomic function in plants. Europe PMC. 2004;31(9):777-783 
[86] Pflieger S, Blanchet S, Camborde L, Drugeon G, Rousseau A, Noizet M, et al. Efficient virus-induced gene silencing in Arabidopsis using a 'one-step' TYMVderived vector. The Plant Journal. 2008;56:678-690

[87] Tao X, Zhou X. A modified viral satellite DNA that suppresses gene expression in plants. The Plant Journal. 2004;38(5):850-860 


\title{
RNAi Induced Gene Silencing Journey from Simple dsRNA to High-Throughput Intron Hairpin RNA Construct in Crop Improvement
}

\author{
Jadhav Pritam Ramesh, Ekatpure Sachin Chandrakant \\ and Wagh Yogesh Sahebrao
}

\begin{abstract}
RNA interference (RNAi) is the process in which short interfering RNA (siRNA) act to inactivate the expression of target genes. The tremendous work done by many research groups around the globe have contributed in deciphering the RNAi pathway. Understanding the role of siRNA and machinery involved in RNAi pathway led to application of this pathway as technique in therapeutic applications and crop improvement. The specificity of siRNA in interacting the target sequence helped to understand the complex pathways and role of major genes involved. Here we have reviewed the journey involved in understanding RNAi pathway and in vitro use of dsRNA to induce RNAi machinery against the target gene. It explains the advances achieved in vector construction from simple RNA construct to high-throughput ihpRNA constructs for higher efficiency in target-specific gene silencing for crop improvement.
\end{abstract}

Keywords: RNAi, crop improvement, vector construction, ihpRNA

\section{Introduction}

The introduction of recombinant DNA techniques and the progression in gene transfer technique and plant regeneration strategies in the 1980s empowered the trading of genes not only between plants of various species but also from viruses, bacteria, fungi, and animals into plants. This capacity to transform plants with transgenes gave unparalleled chances for crop improvement and also widened the scope for upgrading of strategies in genetic engineering. One such strategy developed was RNAi for gene silencing.

The RNAi pathway was first observed in the nematode in response to doublestranded RNA (dsRNA) which resulted in sequence-specific gene silencing. It was then developed as weapon to fight an ongoing war between viruses and living organism from decades. Researchers have been constantly working toward combating virus invasion especially in crops. In this context in 1986, the American plant virologist Roger Beachy and his partners demonstrated an experiment against the tobacco mosaic virus (TMV) infection in tobacco plants. Using gene transformation technique, 
they introduced a transgene derived from the coat protein gene of tobacco mosaic infection in tobacco plants. This virus-based transgene acted against the TMV and protected plant from infection [1]. This finding inspired significant research movement around the globe and prompted numerous reports of protection against a range of viruses infecting plants. However, the underlying mechanism of resistance against viruses using pathogen-derived gene at the molecular level was not known at that time.

The study of Lindbo and Dougherty [2] gave an insight to the happenings at the molecular level. They show that transforming plants with transgenes that can express RNAs of viral origin, but which could not be translated into proteins, could initiate a mechanism that could degrade both the mRNA from the introduced transgene and the genomic RNA of the inoculated virus and lead to repression of the infection by the virus. They also found great similarities with a phenomenon called posttranscriptional gene silencing (PTGS)—which had been described using transgenes of nonviral origin.

Transgene-induced posttranscriptional gene silencing has been detected in plants [3] where it is called co-suppression and in fungi where it is called quelling [4]. In animals, PTGS can be induced by dsRNA in a process called RNA interference (RNAi) [5]. In plants, PTGS can also be induced by viruses expressing host genes in a process called virus-induced gene silencing (VIGS) [6]. Viruses themselves can be the targets of the PTGS machinery [6]. It was proposed that if a cell expresses molecules of the same RNA sequence at a level higher than a certain threshold, this induces a mechanism that specifically destroys that RNA [7]. This proposition led to changes in the way of construct designing and preparation, and the journey from dsRNA construct to high-throughput ihpRNA construct began.

\section{Double-stranded RNA construct for gene silencing}

Based on the Lindbo and Dougherty proposition [2], constructs were made with an aim to increase the copy number of virus-derived transgenes [8]. Constructs contained two sense copies or two antisense copies or contained both one sense and one antisense copy. The transgenic plants with these different constructs were analyzed for virus resistance. They observed that tobacco plants transformed with construct containing both sense and antisense copies showed higher protection against PVY virus. Based on the analysis, they concluded that the production of dsRNA was causing the silencing effect and not the number of gene copies.

Hence, the scientist thought of introducing dsRNA of the target RNA in plant to trigger the silencing mechanism. An experiment was conducted to induce immunity against potato virus $\mathrm{Y}$ (PVY) in tobacco plant [8]. Tobacco plants were transformed with gene constructs that encoded the Pro sequence in the sense or antisense orientation or in both orientations and were challenged with PVY. Less than $15 \%$ of the Pro[s] or Pro[a] lines showed resistance to PVY, whereas the lines containing both sense and antisense genes showed $44-54 \%$ of resistance to PVY. This result suggests that the sense and antisense mRNA in the same cell elicit the PVY resistance. Similar reports were obtained in rice cells transformed with a GUS-derived hairpin (hp) gene. The cells with the GUS gene alone gave a strong blue color, but those with both the GUS gene and the GUS-hp gene remained white [9].

\section{Hairpin RNA construct}

Further the construct was improved with a transgene expressing RNA that folds back and hybridizes with itself to form a structure like a hairpin, instead of making 
two separate RNAs which hybridize into dsRNA [8-11]. With ongoing research and use of RNAi technique for gene silencing, it was observed that silencing efficiency of RNAi vectors can be increased if the factors like selection of target sequences, the inverted repeats, size of the repeats, vectors, use of spacers or introns in the RNAi cassette, promoters, etc. are efficiently worked upon in vector construction. Studies on these parameters were conducted for improvement of hpRNA construct to increase silencing efficiency.

\section{Improvement of hpRNA construct}

\subsection{Selection of target sequence}

Overall efficiency of RNAi is dependent on RNA-protein interactions during siRNARISC assembly and activation $[12,13]$. Hence, a systematic analysis of 180 siRNAs targeting the mRNA of two genes was done to identify siRNA-specific features that are likely to contribute to efficient processing at each step of RNAi [14]. Based on the analysis, characters like low G/C content, a bias toward low internal stability at the sense strand 3 '-terminus, lack of inverted repeats, sense strand base preferences (positions 3,10,13, and 19), etc. were found to be affecting siRNA functionality. An algorithm was designed to incorporate all the eight criteria for the selection of potent siRNA for facilitating the functional gene knockdown studies.

A similar study was conducted to decipher the relationship between short interfering RNA (siRNA) sequence and RNA interference in three mammalian and Drosophila cells by analyzing 62 targets of 4 exogenous and 2 endogenous genes [15]. Based on analysis certain rules were formulated for designing effective siRNAs capable of inducing highly effective gene silencing in mammalian cells. Rules included the sequence conditions, viz., the presence of $\mathrm{A} / \mathrm{U}$ at the $5^{\prime}$ end of the antisense strand and $\mathrm{G} / \mathrm{C}$ at the $5^{\prime}$ end of the sense strand, the presence of at least five $\mathrm{A} / \mathrm{U}$ residues in one-third of the antisense strand toward 5' end, and the absence of any GC stretch of more than $9 \mathrm{nt}$ in length. These rules indicated that siRNAs which satisfy all these conditions will increase the gene silencing efficiency in mammalian cells.

The investigation was done on the use of RNA interference for obtaining resistance against Cotton leaf curl Multan virus (CLCuMV) [16]. Three hairpin RNAi constructs were produced containing either complementary-sense genes essential for replication/pathogenicity or noncoding regulatory sequences of CLCuMV. All three RNAi constructs significantly reduced the replication of the virus in inoculated tissues. However, the systemic movement of the virus was controlled by only one of the constructs (CLCRNAiRepTrAPREn/pFGC), possibly because it spanned three virusencoded genes: the replication-associated protein (Rep), the replication enhancer protein (Ren), and the transcriptional activator protein (TrAP). Also, the ability of virus to infect plant was compromised as the expression of TrAP was downregulated. TrAP is a transcription factor possibly involved in suppression of silencing machinery. Hence, both the target sequence and the levels of identity between the construct and target sequence determined the outcome of RNAi-based resistance against the virus.

On studying the effects of the structure, position, and sequence of a target RNA on RNAi using 47 constructs for inhibition of firefly luciferase activities by siRNAs targeted to TAR motif, it was observed that the efficacy of siRNAs depended mainly on the target sequence [17]. Statistical analysis of the data collected on the sequence preferences indicated that some nucleotides at specific positions are positively or negatively correlated with the efficiencies of siRNAs; for example, the siRNAs with an A residue at the 19th nucleotide position from the $5^{\prime}$ end of the sense strand showed relatively high suppressive activities, and siRNAs with a $G$ residue at the 
19th nucleotide in the sense strand tended to be less effective. Similar preference (A19 in siRNA; U1 in the miRNA) was observed for miRNA sequences [18]. This preference suggests the importance of the low internal stability of the $5^{\prime}$ terminus of the antisense strand and a possible functional contribution of a $U$ at the $5^{\prime}$ end to the activities of both siRNA and miRNA $[12,13]$. A significant negative correlation was also observed between the GC content of the 3' half of siRNAs (in particular, from the 12th to the 19th nucleotide) and the activities of siRNAs. These tendencies can also be seen in another report [19].

The first commercialized transgenic papaya carrying the PRSV CP gene was introduced to Hawaii in 1998 to save the remains of the papaya industry [20]. However, transgenic papaya cultivars showed varying levels of resistance against PRSV isolates from other geographical regions. For example, isolates from the Bahamas, Florida, and Mexico have delayed, mild symptoms. Isolates from Brazil and Thailand also have delayed symptoms, but the virus eventually overcomes their resistance. The CP hemizygous line, "Rainbow," is also susceptible to PRSV isolates from Taiwan [21]. Resistance levels therefore were found to be dependent on the variability among CP genes of the isolates [22-24]. The high levels of genetic divergence in PRSV isolates from Hainan caused the failure of transgenic papaya lines that targets specific viral CP gene [25]. CP-transgenic resistance of papaya is expressed in a nucleotide-sequence-homology-dependent manner [26, 27].

The proper selection of a target sequence for a given gene of interest remains one of the most critical components of successful gene knockdown regardless of the RNAi methodology.

\subsection{Size of repeats}

The silencing efficiency is reported to be proportional to the size of target sequence, and the terminal regions $\left(5^{\prime}\right.$ and $\left.3^{\prime}\right)$ were found to be unaffected by silencing mechanism [28]. This description was based on the experiment conducted to identify the target regions and relative efficiencies of various target regions for silencing of gn1 ( $\beta-1,3$ glucanase) gene in transgenic tobacco line T17.

Similarly, the effect of length of inverted repeats in tobacco BY-2 cells was tested by co-transformation of a luciferase gene construct and a luciferase dsRNA expression plasmid [29]. The dsRNA expression plasmids targeted to the firefly luciferase gene were constructed with 500- and 300-bp inverted repeats. However, no significant difference in silencing efficiency was observed, and the presence of 300-bp dsRNA was found to be sufficient to suppress the luciferase activity in cultured plant cells. A longer dsRNA did not show any enhancement in RNAi effect.

The less silencing frequency is reported when shorter fragments were used [30]. It was based on constructs with fragments of range $50 \mathrm{bp}-1 \mathrm{~kb}$ targeted to silence two Arabidopsis genes, FLC (flowering locus C) and PDS (phytoene desaturase), successfully [30]. The use of fragments between 300 and $600 \mathrm{bp}$ was recommended to achieve effective silencing.

Differences in silencing efficiency were also observed in Neurospora crassa upon introduction of varied size of inverted repeat constructs targeting the albino- 1 gene [31]. Higher silencing frequencies were obtained when the length of the repeat for the target albino-1 gene in Neurospora crassa was kept above 200 and below 900 nucleotides. A substantial decrease in the silencing efficiency was observed when the repeat size was reduced below 200 nucleotides.

The effect of size of granule-bound starch synthase (GBSSI) sequence in inverted repeat constructs was evaluated, and it was found that, for GBSSI, the small inverted repeat constructs were more efficient silencing inducers than the large inverted repeat constructs. The small inverted repeat constructs with a repeat 
size of 500-600 bp and a spacer of about $150 \mathrm{bp}$ were observed to be more efficient silencing inducers than the large inverted repeat constructs where the size of the repeat was 1.1 or $1.3 \mathrm{~kb}$ whilst the size of spacer was 1.3 or $1.1 \mathrm{~kb}$ [32].

Together, these reports suggest that 300-500 bp is the optimal size for inverted repeat for effective silencing mechanism.

\subsection{Vectors}

Construction of RNAi vectors takes considerable time and is a tedious task since it involves laborious conventional cloning technology that relies on restriction digestion and ligation of two fragments corresponding to the antisense and sense region of the stem and subcloning into a binary vector. Hence, there is demand for high-throughput plant RNAi vectors for a rapid and easy construction.

For instance, technique involving a single step for construction of an RNAi vector has been developed that facilitates fast and reliable DNA cloning. It is called as gateway cloning technique which is also available with compatibility for Agrobacterium sp. binary vector system. The backbone of all Gateway-compatible destination vectors is derived from the pCambia series of binary vectors for Agrobacterium sp.-mediated plant transformation. The Gateway recombination site for introduction of a DNA fragment of interest is placed toward the right border of the T-DNA in the pCambia vectors. Most of the T-DNA destination vectors described contain the hygromycin phosphotransferase plant-selectable marker gene. This selectable marker was chosen so that these vectors would be compatible with a large number of insertion lines that are kanamycin-resistant.

For the construction of RNAi vectors using Gateway recombination technology, the PCR products of the target gene are generated with primers flanking attB1 and attB2 sites for recombination with two cloning sites with attP1 and attP2 sequences using BP clonase. pHELLSGATE [30] and pANDA [30] are the vectors that allow the assembly of an inverted repeat structure by Gateway recombination technology [33]. Several pHELLSGATE-related RNAi vectors have been developed for RNAi in monocotyledonous plants and for inducible RNAi [34, 35]. For conventional cloning, pHANNIBAL [36], pKANNIBAL [37], pSAT [38], and pSH [39] are available. In these RNAi vectors, PCR fragments of the target gene are produced by using primers with restriction sites and cloned successively into both upstream and downstream regions of the spacer to become the two arms of the hairpin construct. Simultaneously work was done to enhance the efficiency in cloning inverted repeats for RNAi. An all-purpose vector, pGEMWIZ, for assembling the repeat for any Drosophila gene was developed [40]. The inverted repeats in pGEM-WIZ are stable in common E. coli strains and a fast selection method to correctly identify such clones with repeats is available.

For a simple and efficient construction of intron-containing hpRNA (ihpRNA) vectors, a novel restriction-ligation approach was developed. The system was designed based on the type IIs restriction enzyme BsaI and plant RNAi vector pRNAi-GG based on the Golden Gate (GG) cloning [41]. It required only a single PCR product of the gene of interest flanked with BsaI recognition sequence which can then be cloned into pRNAi-GG at both sense and antisense orientations simultaneously to form ihpRNA construct. The ihpRNA construction process could be completed in one tube with one restriction-ligation step.

\subsection{Use of spacers or introns}

The silencing efficiency of RNAi vectors was reportedly enhanced by the addition of an intron interposed between the inverted flanking target sequences in 
vector. The spacer fragment was observed to give the stability to the inverted repeat sequences. It did not play any role in PTGS and was spliced out during pre-mRNA processing. The process of intron excision from the construct by the spliceosome might help to align the complementary arms of the hairpin in an environment favoring RNA hybridization and promoting the formation of a duplex. Also, splicing may contribute to increase the amount of hairpin RNA by preventing the hairpin's passage from the nucleus or by creating a smaller, less nuclease-sensitive loop [10].

Smith et al. [10] showed that transgene constructs encoding a splicable intron within a hairpin RNA structure can induce PTGS with almost 100\% efficiency. The percentage of PVY-resistant tobacco plants obtained by targeting the nuclear inclusion a (NIa) protease gene of PVY with different constructs was $7 \%$ for the sense gene, $4 \%$ for the antisense gene, $58 \%$ for the hpRNA with a nonspliceable loop separating the sense and antisense arms, and 96\% for the same hpRNA with a spliceable intron. The high efficiency of intron hpRNA constructs for inducing PTGS and generating virus-immune transgenic plants was confirmed for Cucumber mosaic virus (CMV) [42, 43].

The effect of spacer sequences on silencing potential of RNAi constructs was demonstrated [44]. It was tested by an in vivo assay of the $\alpha$-linolenic acid content in hairy roots of tobacco with RNAi vectors against $\omega-3$ fatty acid desaturase (NtFAD3) gene responsible for production of $\alpha$-linolenic acid of root membrane lipids. The frequency of RNA silencing was observed to be more affected by spacer sequences than by spacer length $(100-1800 \mathrm{bp})$. They concluded that it is possible to change the degree of silencing by replacing spacer sequences. They predicted the reason to be interaction of spacer sequences with stem sequences of the hpRNA which affect the formation of a hairpin structure.

\subsection{Promoters}

The degree of silencing is apparently proportional to the level of siRNAs, and the following "strong" promoters have been used in the construction of RNAi vectors: the cauliflower mosaic virus 35S promoter (p35S) [45-47], soybean lectin promoter [48], Arabidopsis rbcS promoter [49, 50], rice ubiquitin promoter [51, 52], and Chrysanthemum rbcS1 [53].

RNAi technique cannot be applied to genes whose silencing interferes with plant regeneration or causes embryo lethality or severe pleiotropic phenotypes. In such cases the inducible RNAi vectors are used which can confer transient and local silencing. Ethanol- or estrogen-inducible vectors were developed for transient RNAi expression. In the case of an ethanol-inducible vector, a transcriptional regulator, $\mathrm{AlcR}$, is constitutively expressed, and the RNAi cassette is inserted behind the alcA promoter. After ethanol treatment, AlcR binds to the alcA promoter and transcription of the downstream RNAi sequences is activated [54]. Also, a Cre/ loxP-mediated recombination and a chemical inducing RNAi vector were developed for the stringent control of expression of an RNAi cassette. A chimeric transcriptional factor, XVE, was constitutively expressed which when binds to estrogen induces the transcription of a Cre recombinase gene. The resulting Cre recombinase removes a fragment that blocks transcription of an RNAi cassette [55]. Similarly, for controlled expression, the $\mathrm{pOp} 6$ promoter was used which could allow the rapid induction of RNAi across the whole plant or in limited tissues under investigation. The induction was controlled by the expression of a synthetic transcription factor, LhGR, which can bind to pOp6 in the presence of dexamethasone and initiate the transcription of downstream RNAi cassette [56]. The pHELLSGATE vector-based inducible RNAi vector is also available [57]. 
RNAi Induced Gene Silencing Journey from Simple dsRNA to High-Throughput Intron Hairpin... DOI: $h t t p: / / d x$.doi.org/10.5772/intechopen.93012

\section{Gene silencing by intron-containing hairpin RNA construct}

Improvement of hpRNA construct for efficient silencing led to the establishment of ihpRNA construct. Using hpRNA constructs containing sense/antisense arms ranging from 300 to $500 \mathrm{nt}$ gave efficient silencing in a wide range of plant species, and inclusion of an intron in these constructs had a consistently enhancing effect. An intron-spliced hpRNA construct gives a higher proportion of silenced transformants than intron-free hpRNA constructs. The process of intron-splicing aligns the arms of the hpRNA, facilitating their duplex formation in the spliceosome complex, whereas the arms of hpRNAs have to find their selfcomplementarity by random tethered collisions. Intron-spliced hpRNA facilitates the more efficient and steady levels of duplex RNA formation that are sufficient for PTGS. Similarly, the tighter loop of ihpRNA gives more nuclease-stable and higher steady-state duplex RNA levels than the larger-looped hpRNA [36]. In plants, intron-containing hairpin RNA constructs with a spliceable intron as spacer sequence had the highest efficiency, with $80 \%$ to approximately $100 \%$ transformants showing silencing of target genes $[10,33,36]$.

\section{Conclusion}

RNA interference has been used to develop efficient strategies to silence targeted genes in a wide range of species. Posttranscriptional silencing of plant genes using antisense or co-suppression constructs usually results in only a modest proportion of silenced individuals. Recent work has demonstrated the potential of the constructs encoding intron-containing self-complementary "hairpin" RNA to efficiently silence genes. The degree of silencing with these constructs was much greater than that obtained using either co-suppression or antisense constructs. Currently, the ihpRNA technology has become one of the most powerful tools for gene discovery and gene engineering in plants.

\section{Author details}

Jadhav Pritam Ramesh*, Ekatpure Sachin Chandrakant and Wagh Yogesh Sahebrao Department of Plant Biotechnology, College of Agriculture, Vellayani, Kerala Agricultural University, Thrissur, India

*Address all correspondence to: prj.jadhav@gmail.com

IntechOpen

(C) 2020 The Author(s). Licensee IntechOpen. This chapter is distributed under the terms of the Creative Commons Attribution License (http://creativecommons.org/licenses/ by/3.0), which permits unrestricted use, distribution, and reproduction in any medium, provided the original work is properly cited. (cc) BY 


\section{References}

[1] Beachy RN, Powell Abel P, Nelson RS, Rogers SG, Fraley RT. Transgenic plants that express the coat protein gene of TMV are resistant to infection by TMV. In: Arnzten CS, Ryan CA, editors. Molecular Strategies for Crop Improvement. New York: A. R. Liss; 1986. pp. 205-213

[2] Lindbo JA, Dougherty WG. Untranslatable transcripts of the tobacco etch virus coat protein gene sequence can interfere with tobacco etch virus replication in transgenic plants and protoplasts. Virology. 1992;189:725-733

[3] Van der Krol AR, Mur LA, Beld M, Mol JN, Stuitje AR. Flavonoid genes in petunia: Addition of a limited number of gene copies may lead to a suppression of gene expression. Plant Cell. 1990;2(4):291-299

[4] Cogoni C, Macino G. Posttranscriptional gene silencing across kingdoms. Current Opinion in Genetics and Development. 2000;10(6):638-643

[5] Fire A. RNA-triggered gene silencing. Trends in Genetics. 1999;15(9):358-363

[6] Baulcombe DC. Mechanisms of pathogen-derived resistance to viruses in transgenic plants. Plant Cell. 1996;8(10):1833-1844

[7] Dougherty WG, Lindbo JA, Smith HA, Parks TD, Swaney S, Proebsting WM. RNA-mediated virus resistance in transgenic plants: Exploitation of a cellular pathway possibly involved in RNA degradation. Molecular Plant-Microbe Interactions. 1994;7:544-552

[8] Waterhouse PM, Graham MW, Wang MB. Virus resistance and gene silencing in plants can be induced by simultaneous expression of sense and antisense RNA. Proceedings of the National Academy of Sciences USA. 1998;95:13959-13964

[9] Wang M, Waterhouse PM. High efficiency silencing of a $\beta$-glucuronidase gene in rice is correlated with repetitive transgene structure but is independent of DNA methylation. Plant Molecular Biology. 2000;43:67-82

[10] Smith NA, Singh SP, Wang MB, Stoutjesdijk PA, Green AG, Waterhouse PM. Total silencing by intron-spliced hairpin RNAs. Nature. 2000;407:319-320

[11] Waterhouse PM, Smith NA, Wang MB. Virus resistance and gene silencing: Killing the messenger. Trends in Plant Science. 1999;4:452-457

[12] Khvorova A, Reynolds A, Jayasena S. Functional siRNAs and miRNAs exhibit strand bias. Cell. 2003;115:209-216

[13] Schwarz DS, Hutvagner G, Tingting D, Zuoshang X, Aronin N, Zamore PD. Unexpected asymmetry in the assembly of the RNAi enzyme complex. Cell. 2003;115:199-208

[14] Reynolds A, Leake D, Boese Q, Scaringe S, Marshall WS, Khvorova A. Rational siRNA design for RNA interference. Nature Biotechnology. 2004;22(3):326-330

[15] Kumiko U, Naito Y, Takahashi F, Haraguchi T, Hiroko O, Juni A, et al. Guidelines for the selection of highly effective siRNA sequences for mammalian and chick RNA interference. Nucleic Acids Research. 2004;32(3):936-948

[16] Mubin M, Hussain M, Briddon RW, Mansoor S. Selection of target sequences as well as sequence identity determine 
RNAi Induced Gene Silencing Journey from Simple dsRNA to High-Throughput Intron Hairpin... DOI: http://dx.doi.org/10.5772/intechopen.93012

the outcome of RNAi approach for resistance against cotton leaf curl geminivirus complex. Virology Journal. 2011;8:122

[17] Yoshinari K, Miyagishi M, Taira K. Effects on RNAi of the tight structure, sequence and position of the targeted region. Nucleic Acids Research. 2004;32(2):691-699

[18] Reinhart BJ, Bartel DP. Small RNAs correspond to centromere heterochromatic repeats. Science. 2002;297:1831

[19] Vickers TA, Koo S, Bennett CF, Crooke ST, Dean NM, Baker BF. Efficient reduction of target RNAs by small interfering RNA and RNase $\mathrm{H}$-dependent antisense agents: A comparative analysis. The Journal of Biological Chemistry. 2003;278:7108-7118

[20] Ferreira SA, Pitz KY, Manshardt R, Zee F, Fitch M, Gonsalves D. Virus coat protein transgenic papaya provides practical control of papaya ringspot virus in Hawaii. Plant Disease.

2002;86(2):101-105

[21] Tennant PF, Gonsalves C, Ling KS, Fitch M, Manshardt R, Slightom JL, et al. Differential protection against papaya ringspot virus isolates in coat protein gene transgenic papaya and classically cross-protected papaya. Phytopathology. 1994;84:1359-1366

[22] Gonsalves D. Control of papaya ringspot virus in papaya: A case study. Annual Review of Phytopathology. 1998;36:415-437

[23] Bau HJ, Cheng YH, Yu TA, Yang JS, Yeh SD. Broad-spectrum resistance to different geographic strains of papaya ringspot virus in coat protein gene transgenic papaya. Phytopathology. 2003;93:112-120
[24] Davis MJ, Ying Z. Development of papaya breeding lines with transgenic resistance to papaya ringspot virus. Plant Disease. 2004;88:352-358

[25] Zhao H, Jia ZR, Zhang Y, Zhu YJ, Zeng H, Kong H, et al. Geographical and genetic divergence among papaya ringspot virus populations within Hainan province, China.

Phytopathology. 2016;106:937-944

[26] Kung Y, You B, Raja JAJ,

Chen K, Huang C, Bau H, et al. Nucleotide sequence-homologyindependent breakdown of transgenic resistance by more virulent virus strains and a potential solution. Scientific Reports. 2015;5:9804. DOI: 10.1038/ srep09804

[27] Jia R, Zhao H, Huang J, Kong H, Zhang Y, Guo J, et al. Use of RNAi technology to develop a PRSVresistant transgenic papaya. Scientific Reports. 2017;7:12636. DOI: 10.1038/ s41598-017-13049-0

[28] Jacobs JJ, Sanders M, Bots M, Andriessen M, Van Eldik GJ, Litiere K, et al. Sequences throughout the basic $\beta$-1,3-glucanase mRNA coding region are targets for homology-dependent post-transcriptional silencing. The Plant Journal. 1999;20:143-152

[29] Akashi H, Miyagishi M, Taira K. Suppression of gene expression by RNA interference in cultured plant cells. Antisense \& Nucleic Acid Drug Development. 2001;11:359-367

[30] Helliwell C, Waterhouse P. Constructs and methods for high throughput gene silencing in plants. Methods. 2003;30:289-295

[31] Goldoni M, Azzalin G, Macino G, Cogoni C. Efficient gene silencing by expression of double stranded RNA in Neurospora crassa. Fungal Genetics and Biology. 2004;41:1016-1024 
[32] Heilersig HJ, Loonen A, Bergervoet M, Wolters AM, Visser RG. Post-transcriptional gene silencing of GBSSI in potato: Effects of size and sequence of the inverted repeats. Plant Molecular Biology. 2006;60(5):647-662

[33] Miki D, Shimamoto K. Simple RNAi vectors for stable and transient suppression of gene function in rice. Plant \& Cell Physiology.

2004;45(4):490-495

[34] Karimi M, Depicker A, Hilson P. Recombinational cloning with plant gateway vectors. Plant Physiology. 2007;145:1144-1154

[35] Earley KW, Haag JR, Pontes O, Opper K, Juehne T, Song K, et al. Gateway-compatible vectors for plant functional genomics and proteomics. The Plant Journal. 2006;45:616-629

[36] Wesley SV, Helliwell CA, Smith NA, Wang M, Rouse DT, Liu Q, et al. Waterhouse PM construct design for efficient, effective and high-throughput gene silencing in plants. The Plant J. 2001;27:581-590

[37] Helliwell CA, Waterhouse PM. Constructs and methods for hairpin RNA-mediated gene silencing in plants. Methods in Enzymology. 2005;392:24-35

[38] Yelin MD, Chung SM, Frankman EL, Tzfira T. pSAT RNA interference vectors: A modular series for multiple gene downregulation in plants. Plant Physiology. 2007;145:1272-1281

[39] Hirai S, Oka S, Adachi E, Kodama $\mathrm{H}$. The effects of spacer sequences on silencing efficiency of plant RNAi vectors. Plant Cell Reports. 2007;26:651-659

[40] Sijun B, Ross C. Fast cloning inverted repeats for RNA interference. RNA. 2006;12:2020-2024
[41] Yan P, Shen W, Gao X, Li X, Zhou P, Duan J. High throughput construction of intron containing hairpin RNA vectors for RNAi in plants. PLoS One. 2012;7(5):381-386

[42] Kalantidis K, Psaradakis S, Tabler M, Tsagris M. The occurrence of CMV-specific short RNAs in transgenic tobacco expressing virus-derived double-stranded RNA is indicative of resistance to the virus. Molecular PlantMicrobe Interactions. 2002;15:826-833

[43] Chen Y, Lu L, Deng W, Yang X, McAvoy R, Zhao D, et al. In vitro regeneration and agrobacteriummediated genetic transformation of Euonymus alatus. Plant Cell Reports. 2006;25:1043-1051

[44] Sayaka H, Shin-ichiro O, Eri A, Hiroaki K. The effect of spacer sequences on silencing efficiency of plant RNAi vectors. Plant Cell Reports. 2007;26(5):651-659

[45] Gavilano LB, Coleman NP, Burnley LE, Bowman ML, Kalengamaliro NE, Hayes A, et al. Genetic engineering of Nicotiana tabacum for reduced nornicotine content. Journal of Agricultural and Food Chemistry. 2006;54:9071-9078

[46] Rutherford G, Tanurdzic M, Hasebe M, Banks JA. A systemic gene silencing method suitable for high throughput, reverse genetic analyses of gene function in fern gametophytes. BMC Plant Biology. 2004;16:4-6

[47] Sin SF, Yeung EC, Chye ML. Downregulation of solanum americanum genes encoding proteinase inhibitor II causes defective seed development. The Plant Journal. 2006;45:58-70

[48] Liu Q, Singh S, Green A. Higholeic and high-stearic cottonseed oils: Nutritionally improved cooking oils developed using gene silencing. Journal 
RNAi Induced Gene Silencing Journey from Simple dsRNA to High-Throughput Intron Hairpin... DOI: http://dx.doi.org/10.5772/intechopen.93012

of the American College of Nutrition. 2002;21:205-211

[49] Rohr J, Sarkar N, Balenger S, Jeong BR, Cerutti H. Tandem inverted repeat system for selection of effective transgenic RNAi strains in chlamydomonas. The Plant J. 2004;40:611-621

[50] Li J, Brunner AM, Shevchenko O, Meilan R, Ma C, Skinner JS, et al. Efficient and stable transgene suppression via RNAi in field-grown poplars. Transgenic Research. 2008;17:679-694

[51] Miki D, Itoh R, Shimamoto K. RNA silencing of single and multiple members in a gene family of rice. Plant Physiology. 2005;138:1903-1913

[52] Travella S, Klimm TE, Keller B. RNA interference-based gene silencing as an efficient tool for functional genomics in hexaploid bread wheat. Plant Physiology. 2006;142:6-20

[53] Outchkourov NS, Peters J, de Jong J, Rademakers W, Jongsma MA.

The promoter-terminator of chrysanthemum rbcS1 directs very high expression levels in plants. Planta. 2003;216:1003-1012

[54] Lo C, Wang N, Lam E. Inducible double-stranded RNA expression activates reversible transcript turnover and stable translational suppression of a target gene in transgenic tobacco. FEBS Letters. 2005;579:1498-1502

[55] Guo HS, Fei JF, Chua NH. A chemical-regulated inducible RNAi system in plants. The Plant Journal. 2003;34:383-392

[56] Craft J, Samalova M, Baroux C. New pOp/LhG4 vectors for stringent glucocorticoid-dependent transgene expression in Arabidopsis. The Plant Journal. 2005;41:899-918
[57] Wielopolska A, Townley H, Moore I, Waterhouse P, Helliwell C. A highthroughput inducible RNAi vector for plants. Plant Biotechnology Journal. 2005;3:583-590 



\title{
Biosafety Issues of Unintended Horizontal Transfer of Recombinant DNA
}

\author{
Getachew Alamnie and Berhanu Andualem
}

\begin{abstract}
Horizontal or lateral gene transfer is the transfer of genetic material from one organism to another organism associated with the unnatural way of reproduction. This way of genetic exchange happens by the stable transfer of genetic material from donor organisms, followed by heritable incorporation to the genome of the recipient organisms. The first explanation of a horizontal gene transfer (HGT) has been a major advance in molecular biology and genetics. Microorganisms like bacteria can acquire genetic material from a variety of sources. The most common DNA transfer mechanisms between microorganisms are conjugation, transformation, and transduction, but there are also other diverse mechanisms of genetic material exchange occurring in nature. Genetically modified organisms (GMOs) often contain recombined genes acquired from different species to enable the expression of new traits in even unlikely or unrelated species. For this, the unintended HGT of rDNA to both prokaryotes and eukaryotes could raise biosafety issues to both human and animal health and the environment. From the current scientific perspective and evidence, the unintended HGT from GMOs to other organisms presents negligible risks to human health and safety or the environment due to the rarity of such events relative to those HGT events that occur in nature.
\end{abstract}

Keywords: antibiotic resistance, genetic exchange, genetically modified organisms, genomics, potential risks

\section{Introduction}

In natural way, DNA is usually transferred from parents to offspring over generations following the normal reproduction pathway of the organism involved, and this type of process is called vertical gene transfer; however, DNA can also more infrequently transfer to unrelated species through a process called horizontal gene transfer (HGT) or lateral gene transfer (LGT) [1]. For this, HGT refers to the stable transfer of genetic material from one organism to the other unrelated organism independent of natural reproduction [2-4]. This way of genetic exchange takes place mostly among prokaryotes. But, with very rare exceptions, HGT occurs much less frequently in eukaryotes. This way of genetic exchange between organisms plays a key role in the evolution of genomes and has been recognized within and between the archaea, bacteria, and eukarya domains as well as viruses $[2,3]$. 
HGT enables the exchange of genetic material even between distant species mediated usually by transduction, transformation, or conjugation. This process can be mediated by the integration of viruses (bacteriophages), transposable elements, or integrative plasmids, often via nonhomologous recombination [4].

More recently, concerns have been raised that HGT from genetically modified organisms (GMOs) have adverse effects [1]. Unintended HGT of an introduced gene in a GMO may confer a new trait in another related or unrelated organism, which could be a source of potential biosafety risk to the health of people and animals or the ecosystem. The studies of Xue et al. [5] and Soucy et al. [4] indicated that rDNA process may become an issue of public health concern due to the existence and spread of antibiotic resistant genes (ARGs) among pathogenic bacteria, and even the nonpathogenic becomes pathogenic due to the acquisition of resistant and virulent genes laterally and more recently with the commercial production of genetically modified crops. Similarly, the study conducted by Lu et al. [6] and Zhang et al. [7] discussed of HGT leading to acquisition or modification of traits as antibiotic resistance, virulence, and nitrogen fixation as a means of new characteristics for the new gene acquired organisms. So the objective of this review is to explore the current understanding about unintended horizontal transfer of recombinant DNA in eukaryotes and prokaryotes and mainly the biosafety risks (human and animal health and environmental aspects) associated with unintentional rDNA introduction into the undesired organisms.

\section{HGT and the nature of heredity}

The first description of a HGT has been a major advance in advanced molecular biology and can even be seen as its founding experiment [4]. A pioneering experiment for the nature of genetic material by Griffith [8], who patented that nonvirulent pneumococcus bacterial strain becomes pathogenic simply by contact with virulent bacteria, even bacteria destroyed by heat, capable of modifying heredity by the process called transformation, revealed that the transforming principle can be even transferred from dead virulent bacteria to living nonvirulent bacteria. Following the interesting breakthrough of the transformation principle by Griffith, Avery et al. [9] demonstrated that the remarkable ability of pneumococci is to acquire DNA horizontally and suggested that the transforming principle is DNA which is the hereditary material of most living cells, and then Hershey and Chase [10] explored that bacteriophage T2 injects its genetic material (DNA) but not its proteins upon the infection of host bacteria. Also, Watson and Crick [11] proposed that in the double-helical structure of DNA molecule, the genetic information would be contained in the specific sequences of nucleotides.

\subsection{Mechanisms of HGT}

Exchange of genetic material between bacterial species is mediated by the basic processes of conjugation, transduction, and transformation. The discovery of the various mechanisms of genetic exchange processes by which bacterial genomes recombine and the historical methods are interesting in themselves but also serve to introduce the diverse processes of recombination. In addition to the above well-recognized exchange mechanisms, there are other mechanisms also involved in genetic exchange mechanisms, and the extraordinary capacity of Agrobacterium in plants to transfer its genetic material to host cells makes it evolve from phytopathogen to a powerful transgenic vector [12]. 


\subsubsection{Transformation}

Transformation is the mechanism of genetic exchange in which free DNA is derived from dead bacteria and is taken up into the cytoplasm of other bacteria. The transformation mechanism of prokaryotes involves integration of free extracellular DNA that becomes incorporated into the genome [13]. Prokaryotic genomes are highly dynamic; they are usually replete with HGT, undergoing continuous gains, often from outside the species, genus, or family, and losses through mutation (i.e., deletion) [14].

\subsubsection{Conjugation}

Conjugation is a one way transmission mechanism of DNA from one bacterium to another via a "sexual pilus" by which DNA is transported. There are interspecies and intergenus transfers of bacterial DNA by conjugation in food/feed and in the intestine. The transfer of genetic material in E. coli conjugation is not reciprocal and one cell, the donor, transfers part of its genome to the other cell, which acts as the recipient by the intermediate of mobile genetic elements, known as integrative and conjugative elements or conjugative transposons, and has been found in many bacterial genomes. Some reports have shown that conjugative transfer in food could have relevant safety consequences due to the mobilization of antibiotic resistance and toxin genes [15].

\subsubsection{Transduction}

Transduction is the bacteriophage-mediated transfer of host DNA between bacterial cells and occurs when newly forming phages acquire host genes and transfer them to other bacterial cells [16]. Occasionally, the newly forming phage particles mistakenly incorporate a piece of the bacterial genetic material into a phage head in place of phage DNA. This event is the origin of the transducing phage and the phage carrying bacterial DNA can infect another cell. That bacterial DNA can then be incorporated into the recipient cells chromosome by recombination. Studies of model phage host systems have revealed mechanisms of transduction and have led to the development of sophisticated genetic methods [17].

\subsection{Detecting patterns of HGT}

Microbes acquire DNA from a variety of sources. The development of genome sequencing has revealed that HGT has been a major evolutionary force that has constantly reshaped genomes throughout evolution [4].

\section{Introduction to biosafety aspects of recombinant DNA}

Theoretically, all genes including highly conserved genes such as ribosomal genes appear to be capable of HGT [18]. Environmental situations including soil, freshwater, seawater, wastes from industry and animals, plant surfaces, human and animal intestines and saliva, and food products may aid HGT. A study investigated by Xue et al. [5] indicated that the transfer of rDNA from GMOs such as transgenic plants to phytosphere bacteria may occur and thus contribute to the undesirable spread of antibiotic resistance determinants and leads to public and animal health risk.

GMOs often contain recombined genes acquired from different species to enable the expression of novel traits in the recipient organism, which leads to new feature and characteristics [7]. As outlined in Akbari et al. [19], some commonly occurring 
new characteristics of rDNA in GMOs can make their transgenes more likely to be taken up and expressed in unintended host cell recipients, which poses biosafety issues of the ecosystem.

Nowadays, globally consumers are concerned about the health and environmental consequences of GM foods. Attitudes toward GM foods and willingness to consume these products vary across countries and among consumer groups based on demographic, social, economic, psychological, or religious factors. While the public acceptance of transgenic foods in Japan and the European Union is low, the use of these products in the United States and in some developing countries is fairly high [20]. For instance, Prati et al. [21] found that Italian consumers have a weak intention to consume GM foods. However, Zhu et al. [22] showed that Chinese consumers are willing to consume GM foods and such willingness is affected by their knowledge of the product and risk perceptions.

\subsection{Principles and methods of biosafety in HGT}

Biosafety means the need to protect human and animal health and environment from the possible adverse effects of the procedures and products of modern biotechnology. For these, there are efforts to protect the environment, human and animal health from the possible adverse effects of the GMOs and products. Because the natures of risks are largely identical for GMOs and non-GMOs, containment measures to handle these risks are largely identical for both. Biosafety pronounces the procedures and policies to be adopted to ensure the environmental and personal safety [23].

\subsubsection{Safety and risk assessment of HGT}

The risk analysis of genetic engineering reveals the nature and magnitude of risk involved, which in turn helps to decide the levels of biosafety practices. Each form of HGT involves different risk considerations; for genetic engineering, these risks are commonly addressed through legislation [18]. Evaluating threats of HGT of rDNA from GM crops involves estimating both the likelihood of transfer of DNA from GM crops to microorganisms or human cells and the impact of such a transfer event [18].

\section{The potential impact of rDNA}

The large-scale production of GM crops will necessarily lead to the release and persistence of rDNA in the natural environments [1]. For this, DNA is continually released from living organisms and therefore is not specific to GMOs and the effect thereof should be seen for other organisms present in the same natural system [24]. Foreign DNA from donor organism can take up and integrate into the genome of a recipient organism and will have a deleterious effect due to its interference with the host cell biology and genome structure. HGT processes resemble mutational processes which may occur by chance and repeatedly over time, but a very low proportion of the HGT events will confer a benefit and be retained in the host over time [25]. As a result, unintended HGT of rDNA to both prokaryotes and eukaryotes could pose risks to the environment and human and animal health and these are the concerns of unintended horizontal transfer of rDNA [26].

\subsection{Risks due to HGT}

The science of rDNA has many potential applications in agriculture, health, environment, and industry. With these different applications, unintended HGT 
has become a greater public concern and needs an amendment of procedures and practices regarding its scrutiny and regulation. In the history of organisms' evolvement, their genetic materials have a history of HGT and evolution. Based on the insight from this concept, a study by Soucy et al. [4], Xue et al. [5], Lu et al. [6], and Zhang et al. [7] discussed that the undesired genetic exchange between different organisms could confer novel traits to the recipient organisms, which may result in negative, neutral, or positive effects to the human and animal health and environment.

\subsubsection{Gene flow}

If there are different allele frequencies in the different populations of a species, then when individuals move to a new population, they will change the allele frequencies in the new population. Environmental implications of gene flow are variable but some of the effects of gene flow are development of superweeds, evolution of new viral pathogens, instability of transgenes in the environment, and creation of pests and pathogens having resistance to new compounds [27]. Concomitantly, secondary effects of gene flow also need to be addressed, including effects on nontarget species, biodiversity disturbance, species displacement and extinction, and disturbance in soil microenvironment and species of ecological concern [28].

\subsubsection{Antibiotic resistance}

The spread of antibiotic resistant bacteria (ARB) and ARG have become an emerging threat to the global health, which has been extensively found in various environments $[1,24]$. By this, HGT which is regarded as one of the major pathways leads to the public health concern by exchanging genetic material that is expressed in the recipient organism [1]. The spread of bacterial antibiotic resistance mainly depends on gene transfer and spontaneous mutation. Mutagenic factors are thought to be the main reason for the induction of antibiotic resistance in the environment [29].

As an alternative, they get mobile genetic factors from other bacteria to obtain antibiotic resistance, which is called HGT. Due to the intensive application of antibiotics in different areas, abundant ARBs and ARGs are frequently detected in environments such as water, soil, and even air, thus posing a potentially health concern [30]. Antibiotics have received special attention due to their potential to promote and maintain bacterial resistance. Particularly, human pathogenic bacteria acquiring ARGs can have severe impacts on human health [31].

\subsubsection{Superweediness}

Recent studies support that domesticated crops could escape from cultivation (ferality) and become a potential weed. Traits like fast growth rate, self-compatibility (crop traits) could favor weediness [32]. A gain of herbicide-resistance gene through hybridization with GM plants could lead toward its persistence in the agricultural habitat [33]. There exists a contradiction among scientists about the establishment of transgene recipients as weeds in the environment. Based on the risk of increased fitness, certain traits are strong candidates which can enhance chances of competitiveness, such as tolerance to herbicides, resistance to various stress, pathogens and pests, and traits responsible for enhanced growth [34]. Plants can develop several herbicide-resistance mechanisms, such as herbicide detoxification, changes in the intracellular compartmentation of herbicides, target site insensitivity, reduced herbicide entry, reduced herbicide translocation, and target site overproduction [33]. 


\subsubsection{Gene escape and biodiversity loss}

Genes can pass on to other members of the same species and possibly other species at the gene, cell, organism, and ecosystem levels. Although research is inconclusive, there is scientific consensus that once widely released, recalling transgenes. The widespread commercial production of GM crops, especially herbicide tolerant crops, poses serious threats to the ecosystem complexity and reduction in biodiversity. To a broader sense, it could be concluded that biodiversity is negatively affected by the cultivation of GM crops [35].

\subsubsection{Evolution of herbicide-resistance weeds}

In the large field of agriculture, there are many evolutionary events that could simultaneously interplay for the emergence of herbicide-resistance gene [36]. In tolerance development, various mechanisms could help the plant, such as target site overproduction, modification in intracellular herbicide compartmentation, minimal herbicide absorbance and translocation, herbicide detoxification, and insensitivity to target site [37].

\subsubsection{Resistance to insecticide and pesticide}

Controlling pests through conventional and chemical techniques have been proven to be challenging, as evolution of insecticide and pesticide resistance has been witnessed in many cases. More specifically, the possibility of evolution of Bt-resistant insect pests cannot be negated because of the constitutive expression of Bt toxins in all plant tissues that imparts higher selection pressure on target species. Use of Bt biopesticides by organic farmers lead to resistant diamondback moth populations in Central America, Florida, Japan, Philippines, Hawai, and China [38].

\section{HGT of rDNA to eukaryotes}

The uptake of food-derived DNA into host cells or tissues has been raised as a potential concern that is related to the introduction of GMO-based food sources $[39,40]$. Among the concerns regarding GM foods are the possible consequences of HGT of recombinant dietary DNA to animal cells [40]. The exposure of the gastrointestinal tract (GIT) to dietary DNA is related to the extent of food processing, food composition, and the level of intake. A minor amount of fragmented dietary DNA may resist in the digestive process of animal feeding [40]. Feed-derived rDNA are taken up from the GIT and detected in the muscle, liver, spleen, and kidneys in chicken and cattle, and it has been estimated that approximately $0.1-1 \%$ of dietary DNA is absorbed from the gastrointestinal tract [41].

DNA is continually introduced into the GIT as a natural part of food. Whereas, the majority of feed-derived DNA is broken down during digestion, and several studies have now shown that minor proportions of feed-derived DNA survive immediate degradation and reach the bloodstream in various animals [42] or are detectable as minor fragments in feces. The fate of chromosomal DNA in the GITs of humans and animals has recently received increased attention due to the introduction of novel ingredients derived from GMOs in the food chain. Biological risk assessment of GMOs has exposed knowledge gaps related to how DNA is degraded or survives degradation in various compartments of the GIT. 


\subsection{The GIT of human}

The human body is a complex ecosystem harboring trillions of bacteria in different body habitats, and the GIT alone is inhabited by $10^{13}-10^{14}$ bacteria [43]. Dysbiosis of the gut microbiota is concerned in a wide range of diseases such as inflammatory bowel disease, diabetes, and cardiovascular disease [44]. The dynamics of these bacterial communities is complex. However, one hallmark of these communities is that bacteria can share different phenotypic traits through a transfer of genetic material.

\subsection{DNA in food}

The broad application of sensitive polymerase chain reaction (PCR) technology has thus exemplified the widespread occurrence and persistence of DNA molecules in various food sources, including processed food such as corn chips and chocolate [45]. Thus, the overall concentration and distribution of DNA of a size that enables entire protein-coding genes to be horizontally acquired from various food sources by host cells or bacteria remains largely undetermined. Studies conducted by Duggan et al. [46] have demonstrated that the persistence of DNA in food revealed that processing often decreases the size of DNA, and such molecules can be undetectable in extensively processed food.

\subsubsection{DNA stability in the digestive tract}

Most free digested DNA molecules entering the digestive system undergo substantial degradation by enzymes attacking DNA, which are released from the pancreas and by the bacteria present in the intestine [47]. DNA fragments are excreted in the feces with variation in the degradation efficiency between mammals. For this, Chowdhury et al. [48] reported that maize DNA could be detected in pig feces. Most studies on DNA stability in the digestive systems of mammals have used purified DNA and may therefore not capture the impact of various food components, treatments, and locations on DNA degradation and stability. Although deoxyribonuclease I (DNase I) is detected in saliva, it is believed that DNA digestion starts in the stomach.

\section{HGT of recombinant DNA to prokaryotic cells}

HGT of transgenes into pathogenic beneficial or environmental microorganisms resulting in potential unanticipated fitness effects has been voiced as a potential biosafety issue. Microorganisms are responsible for the majority of organic matter decomposition; thus, microorganisms present in the human GIT and in agricultural environments experience continual exposure to DNA released from themselves and the organisms in their immediate surroundings [49]. However, in rare circumstances, foreign DNA may also be integrated into the bacterial genome. Experimental studies do not suggest bacteria integrating into foreign unrelated chromosomal DNA at measurable frequencies over the limited time span (hours to days) [50]. Thus, microbial communities are in some cases already exposed to naturally occurring counterparts to these protein encoding genes [50, 51].

\section{Concluding remarks}

From this scientific review, HGT from GMOs to other organisms presents negligible risks to human and animal health and safety or the environment due to 
the infrequency of such events relative to those HGT events that occur in nature. $\mathrm{Ku}$ and Martin [52] have indicated that eukaryotes do not acquire genes through continual HGT like prokaryotes. The risk assessment of a transgenic bacterium must consider the potential for transfer of introduced genes to other microorganisms in the environment. The biosafety aspects of unintended horizontal gene transfer from GM crops that are currently commercialized may become a potential health concern.

\section{Abbreviations}

$\begin{array}{ll}\text { ARB } & \text { antibiotic resistant bacteria } \\ \text { ARGs } & \text { antibiotic resistant genes } \\ \text { GIT } & \text { gastrointestinal tract } \\ \text { GMOs } & \text { genetically modified organisms } \\ \text { HGT } & \text { horizontal gene transfer } \\ \text { PCR } & \text { polymerase chain reaction } \\ \text { rDNA } & \text { recombinant DNA }\end{array}$

\section{Author details}

Getachew Alamnie ${ }^{1 *}$ and Berhanu Andualem²

1 Department of Biology, College of Natural and Computational Sciences, Mekdela Amba University, Ethiopia

2 Department of Industrial and Environmental Biotechnology, Institute of Biotechnology, University of Gondar, Ethiopia

*Address all correspondence to: getachewalamnie@gmail.com

\section{IntechOpen}

(C) 2020 The Author(s). Licensee IntechOpen. This chapter is distributed under the terms of the Creative Commons Attribution License (http://creativecommons.org/licenses/ by/3.0), which permits unrestricted use, distribution, and reproduction in any medium, provided the original work is properly cited. (cc) BY 


\section{References}

[1] Li B, Qiu Y, Song Y, Lin H, Yin H. Dissecting horizontal and vertical gene transfer of antibiotic resistance plasmid in bacterial community using microfluidics. Environment International. 2019;131:105007

[2] Lee WJ. Protocol measuring horizontal gene transfer from algae to non-photosynthetic organisms. Methods X. 2019;6:1564-1574

[3] Siebera KB, Bromleya RE, Hotopp JCD. Lateral gene transfer between prokaryotes and eukaryotes. Experimental Cell Research. 2017;358:421-426

[4] Soucy SM, Huang J, Gogarten JP. Horizontal gene transfer: Building the web of life. Nature Reviews Genetics. 2015;16:472-482

[5] Xue W, Zhou Q, Li F. Bacterial community changes and antibiotic resistance gene quantification in microbial electrolysis cells during long-term sulfamethoxazole treatment. Bioresource Technology. 2019;294:122170

[6] Lu J, Wang Y, Jin M, Yuan Z, Bond P, Guo J. Both silver ions and silver nanoparticles facilitate horizontal transfer of plasmid-mediated antibiotic resistance genes. Water Research. 2019;169:115229 10.1016/j. watres.2019.115229

[7] Zhang T, Hu Y, Jiang L, Yao S, Lin K, Zhou Y, et al. Removal of antibiotic resistance genes and control of horizontal transfer risk by UV, chlorination and UV/ chlorination treatments of drinking water. Chemical Engineering Journal. 2019;358:589-597

[8] Griffith F. The significance of pneumococcal types. Epidemiology and Infection. 1928;27:113-159
[9] Avery OT, Macleod CM, McCarty M. Studies on the chemical nature of the substance inducing transformation of pneumococcal types: Induction of transformation by a deoxyribonucleic acid fraction isolated from Pneumococcus type III. Journal of Experimental Medicine. 1944;79:137-158

[10] Hershey AD, Chase M. Independent functions of viral protein and nucleic acid in growth of bacteriophage. Journal of General Physiology. 1952;36:39-56

[11] Watson JD, Crick FHC. Molecular structure of nucleic acids. Nature. 1953;171:737-738

[12] Guo M, Ye Y, Gao D, Xu N, Yang J. Agrobacterium-mediated horizontal gene transfer: Mechanism, biotechnological application, potential risk and forestalling strategy. Biotechnology Advances. 2019;37:259-270

[13] Ilangovan A, Kay CWM, Roier S, El Mkami H, Salvadori E, Zechner EL. Cryo-EM structure of a relaxase reveals the molecular basis of DNA unwinding during bacterial conjugation. Cell. 2017;169:708-721

[14] Puigbo P, Lobkovsky AE, Kristensen DM, Wolf YI, Koonin EV. Genomes in turmoil: Quantification of genome dynamics in prokaryote supergenomes. BMC Biology. 2014;12:66

[15] Gazzola S, Fontana C, Bassi D, Cocconcelli PS. Assessment of tetracycline and erythromycin resistance transfer during sausage fermentation by culture dependent and -independent methods. Food Microbiology. 2012;30:348-354

[16] Riquelme NA, Leon MF, Santander JA, Robeson JP. Productive infection and transduction by bacteriophage $\mathrm{P} 1$ in the species Salmonella bongori. Electronic Journal of Biotechnology. 2019;41:9-12 
[17] Bergman JM, Fineran PC, Petty NK, Salmond GPC. Transduction: The transfer of host DNA by bacteriophages. In: Encyclopedia of Microbiology. 4th ed. Cambridge, Massachusetts, US: Academic Press; 2019. pp. 458-473

[18] De Santis B, Stockhofe N, Wal J-M, Weesendorp N, Lalles JP, van Dijk J, et al. Case studies on genetically modified organisms (GMOs): Potential risk scenarios and associated health indicators. Food and Chemical Toxicology. 2018;117:36-65

[19] Akbari M, Ardekani FZ, Pino G, Maleksaeidi H. An extended model of theory of planned behavior to investigate highly educated Iranian consumers' intentions towards consuming genetically modified foods. Journal of Cleaner Production. 2019;227:784-793

[20] Zhang Y, Gu AZ, Cen TY, Li XY, He M, Li D, et al. Sub-inhibitory concentrations of heavy metals facilitate the horizontal transfer of plasmidmediated antibiotic resistance genes in water environment. Environmental Pollution. 2018;237:74-82

[21] Prati G, Pietrantoni L, Zani B. The prediction of intention to consume genetically modified food: Test of an integrated psychosocial model. Food Quality Preference. 2012;25(2):163-170

[22] Zhu W, Yao N, Ma B, Wang F. Consumers' risk perception, information seeking, and intention to purchase genetically modified food: An empirical study in China. British Food Journal. 2018;120(9):2182-2194

[23] Wang F, Zhang W. Synthetic biology: Recent progress, biosafety and biosecurity concerns, and possible solutions. Journal of Biosafety and Biosecurity. 2019;1:22-30

[24] Hu Y, Zhang T, Jiang L, Yao S, Ye H, Lin K, et al. Removal of sulfonamide antibiotic resistant bacterial and intracellular antibiotic resistance genes by UVC activated peroxymonosulfate. Chemical Engineering Journal. 2019;368:888-895

[25] Heinemann J, Bungard RA. Horizontal gene transfer. In: Meyers RA, editor. Encyclopedia of Molecular Cell Biology and Molecular Medicine. 2nd ed. Hoboken, New Jersey: John Wiley and Sons; 2005. pp. 223-243

[26] Tsatsakis AM, Nawaz MA, Kouretas D, Balias G, Savolainen K, Tutelyan VA, et al. Environmental impacts of genetically modified plants: A review. Environmental Research. 2017;156:818-833

[27] Beckie HJ, Warwick SI, Hall LM, Harker KN. Pollen-mediated gene flow in wheat fields in western Canada. AgrBioForum. 2012;15:36-43

[28] Layton R, Smith J, Macdonald P, Letchumanan R, Keese P, Lema M. Building better environmental risk assessments. Frontiers in Bioengineering and Biotechnology. 2015;3:110

[29] Lv L, Jiang T, Zhang S, Yu X. Exposure to mutagenic disinfection byproducts leads to increase of antibiotic resistance in Pseudomonas aeruginosa. Environmental Science and Technology. 2014;48:8188-8195

[30] Chen HY, Chen RH, Jing LJ, Bai XM, Teng YG. A metagenomic analysis framework for characterization of antibiotic resistomes in river environment: Application to an urban river in Beijing. Environmental Pollution. 2019;245:398-407

[31] Zhang J, Chen M, Sui Q, Tong J, Jiang C, Lu X, et al. Impacts of addition of natural zeolite or a nitrification inhibitor on antibiotic resistance genes during sludge composting. Water Research. 2016;91:1286-1291

[32] Mercer KL, Emry DJ, Snow AA, Kost MA, Pace BA, Alexander HM. 
Fitness of crop-wild hybrid sunflower under competitive conditions: Implications for crop-to-wild introgression. PLoS One. 2014;9:e109001

[33] Guan ZJ, Zhang P, Wei W, Mi X, Kang D, Liu B. Performance of hybrid progeny formed between genetically modified herbicide-tolerant soybean and its wild ancestor. Annals of Botany. 2015;7:121-128

[34] Yang X, Wang F, Su J, Lu BR. Limited fitness advantages of cropweed hybrid progeny containing insect-resistant transgenes (Bt/CpTI) in transgenic rice field. PLoS One. 2012;7:e41220. DOI: 10.1371/journal. pone. 0041220

[35] Lovei GL, Bøhn T, Hilbeck A. Biodiversity, Ecosystem Services and Genetically Modified Organisms. 131 Macalister Road, 10400 Penang, Malaysia: Third World Network; 2010. ISBN: 978-967-5412-13-4

[36] Bonny S. Genetically modified herbicide-tolerant crops, weeds, and herbicides: Overview and impact. Environmental Management. 2016;57: $31-48$

[37] Brower LP, Taylor OR, Williams EH, Slayback DA, Zubieta RR, Ramirez MI. Decline of monarch butterflies overwintering in Mexico: Is the migratory phenomenon at risk? Insect Conservation Diversity. 2012;5:95-100

[38] Tabashnik BE, Brevault T, Carriere Y. Insect resistance to Bt crops: Lessons from the first billion acres. Natural Biotechnology. 2013;31:510-521

[39] Nawaza M, Mesnage R, Tsatsakisd AM, Golokhvasta KS, Yang SH, Antoniou MN, et al. Addressing concerns over the fate of DNA derived from genetically modified food in the human body: A review. Food and Chemical Toxicology. 2019;124:423-430
[40] Rizzi A, Raddadi N, Sorlini C, Nordgrd L, Nielsen MK, Daffonchio D. The stability and degradation of dietary DNA in the gastrointestinal tract of mammals: Implications for horizontal gene transfer and the biosafety of GMOs. Food Science and Nutrition. 2012;52:142-161

[41] Nielsen CR, Holst-Jensen A, Lovseth A, Berdal KG. Persistence and distribution of intravenously injected DNA in blood and organs of Atlantic salmon (Salmo salar L.). European Food Research and Technology. 2006;222:258-265

[42] Deaville ER, Maddison BC.

Detection of transgenic and endogenous plant DNA fragments in the blood, tissues, and digesta of broilers. Journal of Agricultural and Food Chemistry. 2005;53:10268-10275

[43] Sender R, Fuchs S, Milo R. Revised estimates for the number of human and bacteria cells in the body. PLoS Biology. 2016;14:1002533

[44] Cho I, Blaser MJ. The human microbiome: At the interface of health and disease. Nature Reviews Genetics. 2012;13:260

[45] Rizzi A, Sorlini C, Daffonchio D. Practicality of detection of genetically modified organisms (GMO) in food. AgBiotechNet. 2004;6:1N-9N

[46] Duggan PS, Chambers PA, Heritage J, Forbes JM. Fate of genetically modified maize DNA in the oral cavity and rumen of sheep. British Journal of Nutrition. 2003;89:159-166

[47] Wilcks A, Hoek AHAM, Joosten RG, Jacobsen BBL, Aarts HJM. Persistence of DNA studied in different ex vivo and in vivo rat models simulating the human gut situation. Food Chemical Toxicology. 2004;42:493-502

[48] Chowdhury EH, Kuribara H, Suga K. Detection of genetically modified maize 
DNA fragments in the intestinal contents of pigs fed StarLink CBH351. Veterinary and Human Toxicology. 2003;45:95-96

[49] Nielsen KM, Johnsen P, Bensasson D, Daffonchio D. Release and persistence of extracellular DNA in the environment. Environmental Biosafety Research. 2007;6(2):37-53

[50] Nielsen CR, Berdal KG, Bakke-McKellep AM, Jensen AH. Dietary DNA in blood and organs of Atlantic salmon (Salmo salar L.). European Food Research Technology. 2005;221:1-8

[51] Nielsen KM. An assessment of factors affecting the likelihood of horizontal transfer of recombinant plant DNA to bacterial recipients in the soil and phytosphere. Collection of Biosafety Reviews. 2003;1:79-103

[52] Ku C, Martin WF. A natural barrier to lateral gene transfer from prokaryotes to eukaryotes revealed from genomes: The 70\% rule. BMC Biology. 2016;14:89 



\section{Edited by Kin-Ying To}

Due to rapid population growth, climate change, and decreasing natural resources, growing sufficient crops with high productivity, resistance to abiotic and biotic stresses, and other attractive traits is a major challenge. Conventional breeding methods require time-consuming genetic crosses between different parents for multiple generations. By contrast, plant transformation is defined as the insertion of DNA from any organism into the genome of a plant species, and it is considered to be a powerful tool in plant breeding. This book aims to provide professional state-of-theart information for basic and applied scientists and plant breeders, focusing on key crop plants. Papers related to the principle and application of Agrobacterium-mediated transformation, step-by-step protocols of DNA delivery to the important crop Brassica

oleracea and higher-plant chloroplasts, current progress and prospects of virusinduced gene silencing (VIGS) in higher plants, improvement of grapevine through biotechnology, and public concern of biosafety issues regarding genetically modified organisms (GMOs) are all included in this book. It should be useful for students, breeders, and researchers in the field of transgenic crops around the world. 